\title{
Between the 3 rd and 2nd \\ Millennia BC: Exploring Cultural Diversity and Change in Late Prehistoric Communities
}

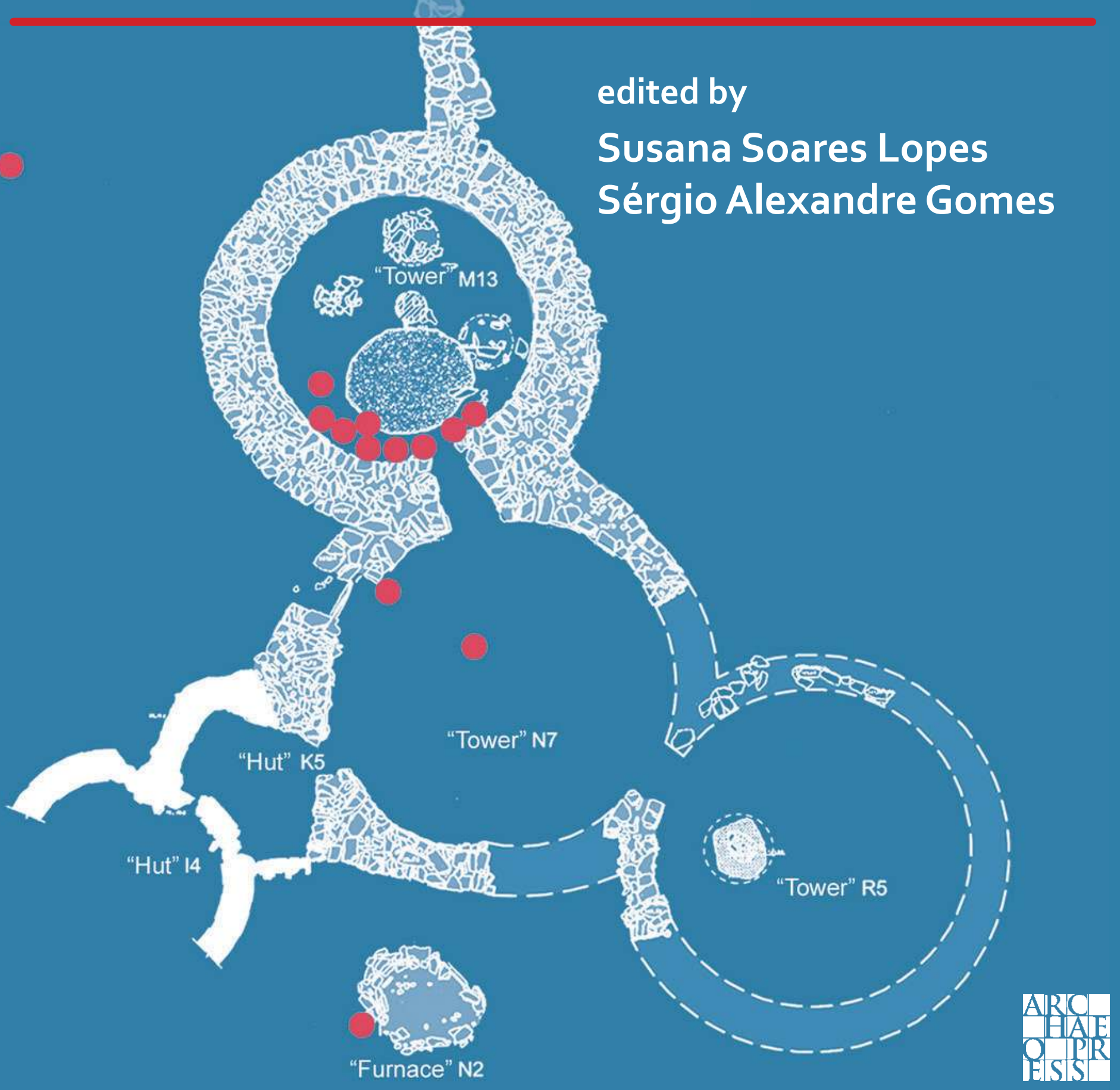





\title{
Between the 3rd and 2nd Millennia BC: Exploring Cultural Diversity and Change in Late Prehistoric Communities
}

\author{
edited by \\ Susana Soares Lopes \\ Sérgio Alexandre Gomes
}


ARCHAEOPRESS PUBLISHING LTD

Summertown Pavilion

18-24 Middle Way

Summertown

Oxford OX2 7LG

www.archaeopress.com

ISBN 978-1-78969-922-7

ISBN 978-1-78969-923-4 (e-Pdf)

(c) the individual authors and Archaeopress 2021

Centro de Estudos

em Arqueologia

- Ciencias do Património
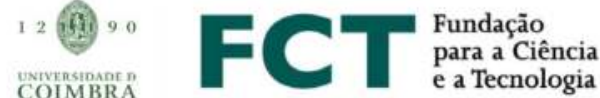

COIMBRA

a Tecnologia

\section{REPÚBLICA}

PORTUGUESA

This work is funded by national funds through the FCT - Fundação para a Ciência e a Tecnologia, I.P., under the scope of the project UIDB/00281/2020 (Centro de Estudos em Arqueologia, Artes e Ciências do Património - Universidade de Coimbra).

\section{(c) (1) ()ㅜ \\ BY NC ND}

This work is licensed under the Creative Commons Attribution-NonCommercial-NoDerivatives 4.0 International License. To view a copy of this license, visit http://creativecommons.org/licenses/by-nc-nd/4.0/ or send a letter to Creative Commons, PO Box 1866, Mountain View, CA 94042, USA.

This book is available direct from Archaeopress or from our website www.archaeopress.com 


\section{Contents}

Chapter 1

Introduction: The Turning of Things.

Susana Soares Lopes and Sérgio Alexandre Gomes

Chapter 2

The Northwest Iberian Peninsula Between the Late 3rd Millennium and Early 2nd Millennium BCE as a Mosaic of Cultural Identities

Ana M.S. Bettencourt

Chapter 3

On Identity and Otherness Reshaping the Dynamics of Late Prehistoric Art Traditions in Northern

Portugal

Lara Bacelar Alves

Chapter 4

The Site of Areias Altas (Porto, Portugal): Current Knowledge of its Occupation in the first Half of the 2nd Millennium BC

Sara Luz

Chapter 5

Searching for the Turning Point to Bronze Age Societies in Southern Portugal: Topics For A Debate

Joaquina Soares

Chapter 6

'Death in the Occident Express': Social Breakdown in Southwestern Iberia at the End of the 3rd

Millennium BC

António Carlos Valera

Chapter 7

A Slow Awakening on the Plain: The Bronze Age in the Beja Region (South Portugal)

Miguel Serra

Chapter 8

Human/Animal Interactions at the Turn of the 3rd to the 2nd Millennium BC. Zooarchaeological Data

from Inner Alentejo, Portugal

Cláudia Costa

Chapter 9

Situated Knowledge and Early Bronze Age Occupation at Must Farm, Cambridgeshire 141

Lesley McFadyen 
:프 


\title{
Chapter 1
}

\section{Introduction: The Turning of Things}

\author{
Susana Soares Lopes \\ CEAACP - University of Coimbra \\ susanasoaresrodrigueslopes@gmail.com \\ Sérgio Alexandre Gomes \\ CEAACP - University of Coimbra \\ sergiogomes@uc.pt
}

\section{Introduction}

It is generally agreed that during the 3rd millennium BC (Chalcolithic) and the 2nd millennium BC (Bronze Age) complex transformations of the social dynamics within the diverse communities inhabiting the different regions of Europe occurred. This book intends to revisit such consensus by highlighting how researchers explain these transformations and differences. The volume assembles some of the contributions presented at the seminar 'In between the 3rd and 2nd millennium BC - Which kind of turn?' held at the University of Coimbra (Portugal) in November 2018. The meeting aimed to examine different points of view on the topic, asking what archaeological evidence could be analysed to discuss the turning process. During the seminar, talks were presented about different geographical units in Western Europe. Most focussed on the Portuguese territory, however, as our original goal was not to present a synthesis on this region, we also invited researchers working in the UK, Spain and France (Lopes and Gomes 2018). In doing this, we were aiming to expand our view of the Portuguese territory, widen our insights into the turn between the Chalcolithic and the Bronze Age, and to contribute to a better understanding of our possibilities of investigating the development of European Late Prehistoric cultural diversity by positioning it within a broader geographical scale. This also allowed the addition of diverse perspectives in questioning the subject and brought together colleagues working within different institutional contexts and inspired by disparate conceptual backgrounds.

It was decided, for the purposes of this volume, mainly to concentrate on the Iberian Peninsula. By limiting our focus to this region, we felt we could thoroughly examine the differing approaches and interpretations of the turn between the Chalcolithic and Bronze Age. Although this chapter, and the others in this volume base their discussions around the Iberian Peninsula, we decided we had to include McFadyen's provocative paper on Cambridgeshire. Her analysis of the singularity of the 'Must Farm' landscape raises important questions about the limitations of archaeological narratives based on linear perspectives and periodisation. These questions, and those raised by the other papers presented at the seminar, form the basis of this introductory chapter.

We want to be very clear that we do not see this volume as answering all the questions that can be asked about the turn from the Chalcolithic to the Bronze Age, rather we see this volume as part of an ongoing discussion, one that ranges beyond the turn itself and begins to examine the very questions we should ask about this period. In order to begin this conversation we have not written the standard style of Introduction to a volume of edited papers, although we do discuss these papers in detail below, we have taken the opportunity to include the questions that occurred to us as we reread these papers, the areas that we think would be most interesting to explore. We were also revisiting our thoughts and motivations in organising the seminar; how we wanted to discuss the possibilities of understanding the nature of the turn between the 2nd and 3rd millennia. Additionally, we decided to present our own brief essay on the Serra da Aboboreira located in Northern Portugal (see below). Our aim is to attempt blending a narrative based on landscape, periodisation and coexistences. In doing this, we conclude that in the discussion of the turning points - or, in other words, in the discussion of the cultural becoming - one should always think about the topology of things, situating traditional and novel elements in order to question what things can tell us about the historical tensions under which long reconfiguration processes occurred. In exploring such a topology, can we move towards an understanding of the historical singularity of past remains and, in doing this, become closer to creating a narrative on the turning of things; a narrative situating things and talking about how they may have changed the world under which they emerged? This is how we would like readers to experience this book: as an 
attempt to understand our knowledge and imagine what further investigations can be made into late prehistory.

We will begin by discussing the papers included in this volume, analysing their similarities and differences in approach and understandings of late prehistory. The first three chapters discuss data from the Iberian Northwest: Bettencourt (Chapter 2) presents a synthesis of this region by discussing a wide range of archaeological data (from pottery to DNA analysis); Alves (Chapter 3) focuses her perspective on the dynamics of Late Prehistoric art traditions in Northern Portugal; and Luz (Chapter 4) analyses a single Bronze Age site located in Porto. These three contributions use very different analytical frameworks in their approach and concerns in thinking about the late prehistory of this region. The Iberian Southwest is the focus of several chapters: Soares (Chapter 5) searches for the turning point of Bronze Age societies in Southern Portugal; Valera (Chapter 6) discusses how monumental ditch enclosures may be understood as an historicgeographical context marking the end of the Neolithic worldview during the 3rd millennium; Serra's goal is to tell the story of a particular landscape (the plain of Beja) after these monuments have been abandoned, and how the Bronze Age ends in new monumental cycle (Chapter 7); Costa (Chapter 8), by contrast, discusses the differences between the 3rd and 2nd millennium through the faunal remains.

These texts suggest different perspectives and approaches to late prehistory, demonstrating how the coherence of our work as prehistorians is based on the multiple choices we make while developing research strategies. McFadyen's contribution (Chapter 9) is geographically decentred, however her perspective allows us to emphasise the heterogeneity of thinking on the subject. In a sense, the geographical difference of her chapter allows us to reinforce our standpoint that the aim of the seminar, and of this book, was not only to discuss the regional diversity of the archaeological data but also to think about the disparate perspectives on the data. Ironically, as we will see, McFadyen's alternative stance is based on her options regarding the geographical scale of analysis.

This group of eight texts allows multiple discussions of the variety of approaches, interpretations and styles of writing used in thinking about the past. We will begin by examining the geographical range, taking the geographical scale not only as a process of regional delimitation but as a strategy for analysis chosen by each author. This first approach to the chapters will demonstrate how the geographical dimension of the analysis is deeply intertwined with the ideas and discourse that each author wants to construct with their exploration of the archaeological data. The chapters focusing on Portugal allow a comparison of the role of monumental architecture, funerary contexts, and deposition contexts in each author's narrative, and so we decided to present an individual section on this topic. The reading of these chapters suggests an image of the cultural becoming as one of change and disruption. This has long been the consensus on this period and these chapters present important perspectives for revisiting that understanding. However, McFadyen's chapter offers us an opposite view by asking about longterm dwelling and situated knowledge (after Haraway 1991, and Ingold 1993). These different approaches suggest that questions need to be asked regarding the coexistence between what is interpreted as being from the old world of the Chalcolithic and the new world of the Bronze Age. In presenting the chapters focusing on the Portuguese territory we wanted to raise this question and look at how we might explore this direction in further research.

The different approaches taken by these authors result in different narratives whose comparison is also an interesting exercise in understanding the differences between the authors. The Narrative Styles section (below) is a contribution to understanding how our research frames the story we tell; thus it also sets the possibilities of making sense of the changes within the archaeological record between the 3rd and 2nd millennia. At the core of the consensus about the transformations of the social dynamics there is also a tacit agreement that periodisation is one of the main strategies that archaeologists have to create order out of the heterogeneity of the archaeological data. Periodisation allows narratives about continuity and collapse to explain the transformations and also permits the creation of longer or shorter periods, producing different rhythms for the historical processes. All these options intertwine with the way the narrative is then constructed by each author. In turn, McFadyen shows how an analysis focusing on the landscape and situated knowledge allows us to create a different narrative from those authors privileging periodisation. In this sense, her paper enables us to revisit the consensus while resisting its pressure on the ways we think and organise long-term processes in studying late prehistory.

Periodisation played a major role in our organisation of the original seminar and the subsequent rethinking as we brought together this volume. We were trying to discuss the possibilities of understanding the nature of the turn between the 3rd and 2nd millennia and we asked 'which kind of turn?'. Periodisation is the most immediate strategy to answer this; discussing different periodisations, alternative explanations and regional variability is a way to demonstrate the complexity of the theme. Asking 'which turning points?' is another 
necessary question for bringing order to the discussion and the narrative style. However, while these two questions are both necessary and enlightening, they often shape the answers into a linear perspective on the subject. In order to create a different conversation and divergent perspectives, we suggest a different question 'between the 3rd and 2nd millennia: what should we be asking?'. Perhaps such a question could create the conditions to rethink the ways to narrate the turning and understand its nature. By wondering what to ask of particular archaeological evidences we may find a way to rediscover the singularity of past remains, the otherness of past communities, and the differences of approach by the researchers committed to its study.

\section{Geographical scale(s)}

Reading the eight chapters challenges us to understand a dialogue between the Mediterranean and Atlantic worlds. The analysis of Bettencourt and Alves on the Iberian Northwest questions these biogeographical unities, stressing that there was a permeable border during the 3rd and 2nd millennia. Soares and Valera focus on the Iberian Southwest, referring to the dynamics between the Western and Central Mediterranean. In this regard, Valera's perspective should be noted because of the emphasis he places on geographical thinking to make sense of the archaeological data. His approach directly refers to the insertion of local communities into an historicalgeographical complex that places different parts of the Mediterranean in an intense cultural dialogue during the 3rd millennium. According to Valera, the end of such cultural dynamics would have resulted in the collapse of the Neolithic worldview and the beginning of a different order.

In contrast to these regional approaches, there are two chapters whose geographical scales are particular landscapes. Serra's analysis is centred on the Alentejo peneplain and looks at how monumental architecture would have contributed to the landscape reconfiguration during the 2nd millennium $\mathrm{BC}$. This interest in the disruptive character that monuments may have had in the landscape contrasts with McFadyen's perspective. In discussing Must Farm archaeology, rather than looking for disruptive turns, McFadyen directs her analysis toward an understanding of the conditions under which past communities stayed in a place. Her aim is not to identify different landscape marking strategies but the contextualisation of the landscape's knowledge and practices. Correspondingly, for Costa and Luz geographical scale is expressed in the attention given to such knowledge and practices. Costa emphasises a change in the faunal record between the 3rd and 2nd millennia BC in the Alentejo peneplain, arguing for a transformation in the relationship between human and animal communities. Luz focuses on a pit site - Areias Altas - dating from the first half of the 2nd millennium $\mathrm{BC}$, located near the sea at Porto, exploring the possibility that the site was related to salt production and how the artefactuality of such a custom may have participated in practices of deposition.

In considering the above-mentioned diversity, this volume provides different perspectives on the geographical dimension of archaeological data. In the first group of texts, there is a comparison between the territories of a wide region, searching for a regional synthesis to overcome the (in)coherence and heterogeneity of the archaeological data. This comparison between territories led Soares and Valera to recognise the role of large-scale relationships of dependency in explaining the cultural changes of communities in southern Portugal. Such a comparison also allows Bettencourt to emphasise that from the middle of the 3rd millennium $\mathrm{BC}$ onwards the Iberian Northwest present different rhythms of change. Alves uses the comparison in a different way. Her analysis of different rock art traditions - schematic art in the hinterland Mediterranean region and Atlantic art - and its role in the creation of landscape make her realise how both, regardless of their differences, are expressions of the same Neolithic worldview, ending at the beginning of the 2nd millennium. In this sense, Alves's emphasis on the landscape makes her closer to the second group of texts, in which the analysis pays attention to the particularities of local geographies. Regarding these different geographical approaches, we would again like to stress that for each author geographical scale is a condition emphasising both their discussion of the past remains and the narrative that they want to create. This is particularly so in McFadyen's chapter, her analysis of the singularity of the landscape is a strategy to overcome the limits of an archaeological discourse based on periodisation, challenging the structure of normative archaeological narrative.

\section{Perspectives on monumental architecture, settlements, burial contexts and practices of deposition on the western façade of the Iberian Peninsula}

Since the middle of the 20th century, general syntheses focusing on the late prehistory of Western Europe have stressed the contrast between the 3rd and 2nd millennia BC (Aranda Jiménez et al. 2015; BlancoGonzález et al. 2018; Cruz Berrocal et al. 2013; Lilios 2019; Meller et al. 2015; Müller et al. 2019, just to mention some more recent titles). Such overviews highlight how the great monuments and collective identity rituals of the 3rd millennium BC - fixing the matrix of a Neolithic worldview - had continued into the 2nd millennium BC. Following this, new, individualised powers, with 
little visual monumental expression, emerged all over western Europe. From an architectural point of view the novelty of the Bronze Age world was initially almost invisible. And yet, paradoxically, it was this world that contained the potential social/political conditions which gave rise to the hierarchical/proto-state powers that ended the story of Western European prehistory. In contrast, our seminar invited researchers to alter the scale of analysis to question this change by basing their investigations locally or regionally. Thus, it was also about discussing the cultural differences between the local communities of the 3rd and 2nd millennia BC. Overall, the seminar was intended to expand and reinterpret these hegemonic large-scale narratives.

The south of the Portuguese territory is analysed as a whole by the authors discussing this region. Valera establishes and characterises a long historical period (from the 4th to the end of the 3rd millennium BC) with a vigorous, unitary identity, manifested, for example, in the monumentality of architectural devices (enclosures of different types), in supraregional interactions promoting exchanges of artefacts made of exogenous materials, or in heterogeneous ceremonial practices associated with a wide range of social contexts. During the 3rd millennium, there was an acceleration and intensification of the monumental architecture tradition and supra-regional interaction. This acceleration/intensification process would have created the conditions for its complexity. Simultaneously, this process is also understood by the author as creating the conditions for its implosion. The Chalcolithic world is then the apex of a linear process of growth, and, concomitantly, of collapse at the end of the 3rd millennium BC. Valera does not discuss what may have happened after such a devastating decline. However, complementing this view, Serra discusses the Alentejo Plain during the 2 nd millennium $B C$, describing the emergence of a society with little archaeological visibility. This society is materialised through pit sites, necropolises of cists, possibly associated with stelae; it is of a different organisation and social complexity, where individualised powers emerged without the need for the wide-ranging monumental choreography of the earlier powers of the $3 \mathrm{rd}$ millennium BC. From this perspective, this so-called Middle Bronze Age seems to be a counter-cycle, after the expansion/collapse (Chalcolithic) and immediately before the community awoke to a new cycle materialised in the emergence of new enclosures associated with the complex communities of the Late Bronze Age. In addition to these complementary perspectives, Costa accentuates the differences between the Chalcolithic and Bronze Age contexts in the zooarchaeological record, allowing the reader to visualise a linear sequence between the two worlds.
Soares presents a different periodisation to the one suggested by Valera and Serra, nevertheless, it is also a perspective privileging a linear sequence. The local Chalcolithic tribal communities were experiencing social disarticulation. This unstable social context leads to the emergence of incipient chiefdoms around 2500 BC. In arguing this, Soares emphasises the appearance of individual funerary practices associated with Beaker pottery and novel metal objects. Such burial practices were changes in continuity, in the sense that they represent the emergence of embryonic personal powers within the unstable political context of a tribal society. The advent of such social individuality, Soares argues, is a milestone marking the beginning of the Bronze Age. In the analysis of this new world, the author reviews data from settlements and burial contexts that had little impact on the landscape. By searching for elements indicating social and political complexity during the 2nd millennium, she identifies the formation of proto states ruled by chiefs, under the influence of the El Argar state located in the south east of the Iberian Peninsula.

A fundamental question arises while reading these chapters about southern Portugal: how to interpret the coexistence between traditional/communal Chalcolithic contexts and individual contexts during the second half of the 3rd millennium? One should emphasise that the 'Ferradeira Horizon' (Schubart 1971; 1975) associated with Beaker pottery is well known in the literature and often interpreted as an expression of a complex socio-political change. There is an ideology of individuality expressed by the 'Ferradeira Horizon' coexisting with the Chalcolithic tradition. Soares often uses it as a matter of classification; Serra refers to it when considering its role in the regional periodisation. The question of the coexistence of communal and individual funerary practices would be an interesting topic of further research and debate to understand the turn between a world where expressions of individuality are lacking, to a world which is structured by such an ideology. We will return to this in our discussion of Serra da Aboboreira.

As mentioned, the chapters about Northern Portugal accentuate the differences between the Atlantic littoral and the Mediterranean hinterland. This division is used by Bettencourt as a means to explore an asymmetric cultural evolution: a coastal area which presents elements of a new world from the middle of the 3rd millennium; and a hinterland whose chalcolithic traditions seems to resist the adoption of novelties. Despite this regional diversity, Bettencourt's chapter presents a global linear sequence, also reviewing and reinterpreting data from neighbouring Galicia, which results in a synthesis of the Iberian Northwest. From this perspective, the author argues that since the middle of 3 rd millennium there are changes - new cultural 
interactions, for example - leading local communities to take different paths; these changes become more intense during the last quarter of the millennium, resulting in a multiplicity of communities, who, however, may have shared the same social structure. In this understanding of becoming, Bettencourt stresses how Chalcolithic communities (polarised around monuments of Neolithic tradition, including different kinds of enclosures) evolved into communities with a sense of individuality expressed in different funerary contexts (with individual or restricted numbers of inhumations), accompanied by offerings of metal weapons and jewellery. Alves also emphasises that in the littoral rock art sites - Atlantic rock art - there is a change in the motifs; new engravings appear consisting of halberds and daggers. Alves's argument about these engravings is of a different nature. In her chapter, art is questioned from a landscape perspective. This point of view allows her to understand that the novelties highlighted by Bettencourt should be interpreted as new motifs in a Neolithic rock art tradition. The engravings of halberds and daggers do not alter how Atlantic rock art crafts the landscape, rather, it is an updating of the traditional Neolithic worldview. Her argument strengthens as she compares Atlantic rock art to schematic rock art showing a similar ontological frame. In doing so, Alves suggests that the change should be looked at as the differences between rock art and statuary, and how this last expression would become a hegemonic art expression during the Bronze Age (stelae and/or armed statues). Here, too, a linear sequence is obvious. However, admitting the addition of engraved weapons into the Neolithic worldview could contribute to a discussion of the social nature of certain signs and the possibilities imaginable for interpreting an engraving.

These two chapters present a contrast between approaches: Bettencourt plays with a wide range of archaeological data, aiming to organise it into a historical process; Alves focuses on art expressions to understand their landscapes. Their interpretations are very different but equally persuasive, and a dialogue between the two approaches would be a constructive area for further research discussing the coexistence between the old and new world, such as the "Montelavar/ Carrapatas Horizon' (mentioned by Bettencourt; see also Harrison 1974; 1977; Schubart 1973).

Luz's chapter focuses on Areias Altas, a Middle Bronze Age pit site from the littoral north of Portugal. While her contribution does not reflect the discussion of periodisation, or the turn between the old and the new world, her contextual analysis of the social role of deposition practices during late prehistory provides an important topic for discussion. By looking at pit fills, Luz highlights how the pits may have been architectural devices created under diverse social settings, such as the production of salt and the practices of deposition. Although these deposition practices are assigned by Valera and Bettencourt to the 3rd millennium, they make little reference to their material and social nature. Costa also discusses these phenomena, mentioning the deposition of articulated animal bones in funerary and dwelling contexts. It is therefore worth stating that the Chalcolithic deposition practices, associated with a community ceremonial social scenario, also occur in the Middle Bronze Age, as highlighted by Luz (for further information about the relevance of these contexts in the South of Portugal during Late Prehistory, see Baptista and Gomes 2019; Gomes and Baptista 2017; and Valera 2019). That depositions can be identified so late makes it imperative that we should be examining and debating the formal and social typology/nature of these contexts. It is likely that throughout the 3rd and 2nd millennia BC, practices of deposition could happen in the most diverse places, organised according to different orders, and related to incongruent social practices. The intentional deposition of disparate materials may cross the margin of the $3 \mathrm{rd}$ and into the 2nd millennium BC, contributing, in the most diverse and opposite ways, to the consolidation of two antagonistic worlds. Regarding this, 'deposition' is then a conceptual 'umbrella' for different archaeographic/ social realities, whose historical uniqueness needs to be investigated for the information it may reveal about the differences between these two worlds.

By reading these chapters as a whole, we are presented with variations of the same global linear approach, admitting, explicitly or implicitly, that the observable changes between the 3rd and 2nd millennia BC are related to alterations in the social structures of power. For example, the disappearance of Neolithic monuments and the emergence of individual/restricted burial contexts (in old or new spaces), accompanied by differentiated ceramic/metallic assemblages, is interpreted as a break between the old and the new worlds. For Soares and Bettencourt this rupture still begins in the second half of the 3rd millennium $B C$ - as soon as the new individual burials appear. When these occur, these authors talk about an 'Early Bronze Age', a transition period between the old and the new. This coexistence is interpreted as an hegemonic indicator of a new world ahead, but it may also disclose a cultural meaning we can further explore.

\section{Narrative styles}

In this section, we will highlight how the archaeological analysis intertwines with aspects of the narrative style chosen by the authors (after Pluciennik 1999; see also Gomes 2020). We will compare how the chapters present different rhythms to the processes under which the turn occurred; how these rhythms entail different scales of observation expressed in the storytelling; 
and how these associations come to an argument or a point of view on the question of the seminar. In doing this, our aim is to understand how we can construct narratives to answer the question 'What kind of turn?', and see where such an understanding can take us.

The chapters about the Portuguese territory offer a perspective on the turn between the Chalcolithic and the Bronze Ages; or, in other words, the ending of the old Neolithic world and the beginning of a new cultural and political order on the western facade of the Iberian Peninsula. To the north of Portugal, Bettencourt points to an early chronological turning point on the coast, around 2400/2300 BC, whose manifestation in the hinterland only becomes visible around 2200/2000 BC. These turning points, marking her narrative, are the results of her analysis of the temporal and spatial distribution of the archaeological data. In organising the heterogeneity of data, she enlarges her geographical scale of analysis, exploring the north west of Iberia to explain the diversity of material; it is a detailed order which by itself constructs the narrative. However, while it is true that the author plays with both time and space, it is time (chronology) which structures the narrative, as she focuses on the last quarter of the 3rd millennium $B C$, as a privileged moment to understand the turn. In contrast, Alves chooses only art expressions (rock art and statuary) to construct a narrative where different art traditions produce landscapes and identities. In so doing, she explores the cultural diversity within the Neolithic and demonstrates how such diversity constitutes the otherness of this world. The discernment of such an alterity and its comparison with the Bronze Age, is used by Alves to argue that the understanding of their difference is not so much a matter of time, or chronological division, but a matter of space, translated into different landscape dynamics.

Soares discusses the disarticulation of Chalcolithic communities in the south of Portugal around $2500 \mathrm{BC}$, which leads her to consider an Early Bronze Age. This is the first stage of a process which, between 1800 and 1200 BC (Middle Bronze Age), marks the emergence and consolidation of proto-state regional powers. Soares's narrative is based upon a tight periodisation, centred on a social and economic evolutionary process, influenced by Marxist and anthropological theory. In her discussion she also questions how the increased social complexity through the Middle Bronze Age is recognised (see also Soares and Silva 2016). In Valera and Serra's chapters, the change - or the global turn - occurred later, around 2200/2000 BC. Valera talks of the collapse of a Neolithic world, assuming the existence of a historical entity from the end of the 4th millennium and expressed by the construction of several ditched enclosures. These monuments are thus the main character of this narrative, Valera argues that they express a process of intensification and complexification of a supra-regional network defining this chronological period. The abandonment of such monuments would then mark the end of this world and the beginning of a new era. Serra's chapter tells the story of a world without monuments until the construction of new ones, during the Late Bronze Age. Despite their dissimilarities, these authors see the background of these different historical explanations as based on the importance of endogenous factors, even if natural influences (climate changes, for example), or cultural influences (the proximity to El Argar and the interaction with the Central Mediterranean) may have hastened or transformed the nature of change. Additionally, while acknowledging the differences between these narratives, we may say that Soares is privileging - as did Bettencourt - the chronological division as a means of ordering the narrative, whereas Valera and Serra, like Alves, base their storytelling on a spatial dimension, asking how particular features structure the local landscape and relate to broader geographies.

The diversity of narratives also suggests different perspectives on the rhythms of historical processes. The detailed periodisation advanced by Soares suggests communities in constant response to internal and external changes, gradually consolidating a sense of territorial and sedentary identity which organises people, goods and ideas according to vertical relations of power. Bettencourt presents the Iberian Northwest according to a similar narrative order resulting, however, in a divided region moving, changing, and living to different rhythms. The gradual nature of the turn of these narratives contrasts with the historical acceleration proposed by Valera. In response to an exponential increase in the number and dimension of ditch enclosures over the 3rd millennium, Valera's narrative highlights the density of a network allowing the circulation of goods and people who share a Neolithic worldview. This system leads to collapse because the acceleration is not accompanied by the necessary reconfigurations for its maintenance or transformation. In contrast, Serra's narrative of the 2nd millennium is a slow awakening of the plain.

The rhythm of historical processes proposed by these authors becomes a way of shaping the narrative. This is illustrative in understanding the difference between Soares and Valera's narrative. Soares's gradual changes (and detailed periodisation) are made by interpreting each novelty of the archaeological record as an indicator that 3rd millennium communities were always changing their social nature. In Soares's narrative, the Chalcolithic is seen as a world in crisis seeking stability. Given this, any novelty is interpreted as restructuring the social dynamics towards a stable order. Valera's point of view is quite different; he sees the 3rd millennium as a great moment of the monumental Neolithic. There is no 
crisis, instead he sees a world whose characteristics are interaction, permeability, and transmutability, allowing and integrating novelty. In such a permeable world, any novelty acts as an element accelerating the process of growth until its implosion. The shape of the narrative represents the general image that the authors have of the historical conditions framing the archaeological evidence they study. The rhythm, both from the historical process and the narrative, then becomes as persuasive as any argument they may present.

McFadyen's main character is also the landscape. However, her narrative is markedly different. She is analysing another reality, but besides that, she is also creating a different narrative avoiding the restrictions of periodisation. To analyse her narrative, let us start with an archaeological entity that she has in common with other authors: the beaker pottery. Having referred to it, she is not interested in understanding its novelty. Instead, she situates this new element - situates its knowledge within the landscape. From this perspective, she has an image of a beaker within a landscape and constructed in the same way - before, during, and after the emergence of this historical element. As important as the beaker is, it is the repetitive and daily gestures of caring for the landscape which provide the circumstances for this beaker existence. This is a challenging perspective, but it also entails asking what kind of visible and meaningful changes on a landscape can we see when considering the novelty of particular artefacts? McFadyen's narrative goes beyond the continuity/discontinuity dichotomy organising the other narratives. Rather than resistance or tradition, it is organised by seeking to do justice to the tenacity of prehistoric communities. A tenacity expressed through long-term practices, which, in their repetition and difference, take care of a landscape and its (in) finite possibilities. This emphasis on tenacity does not seek novelties as indicators of adaptation or collapse, but as an understanding of the situated knowledge of a landscape. In this sense, periodisation is not an adequate strategy or narrative to think about this knowledge, because continuities and ruptures cannot reflect the centrality of caring for a place enacted by that place's community. It may initially seem that McFadyen is far from answering the question of the seminar, however, by following her thoughts - and reaction to periodisation - we find an opportunity to rethink what we emphasise and what we overlook while thinking about long-term perspectives.

McFadyen's narrative does not advance our thinking on the problematisation of the historical process, however, it requires us to think of the turn at the landscape scale, without attempting to define a global explanation. This entails a different focus from the ones proposed by Bettencourt and Alves, highlighting the differences of two biogeographical regions, by Valera, whose thoughts are made by considering a historicalgeographical complex, and by Serra, whose landscape is analysed by studying cycles of monumentality. McFadyen's focus is on the becoming of the landscape and refers to situated knowledges. Such a perspective allows an emphasis on the coexistences we refer to in the previous section. At the scale of the landscape, it is possible to situate and discuss the coexistence of material that we consider to be an expression of Neolithic and Bronze Age worldviews. Investigation of this coexistence may allow deeper understanding of the turn; an understanding resisting periodisation and its grammar of chronological succession ordering archaeological data. This is a difficult task, but it is worth the attempt. In the following section, we will assay this by discussing a set of coexistences at a landscape in the north of Portugal: the Serra da Aboboreira, a granitic mountain in the Douro Valley, comprising long plateaus at the summit and small platforms with streams on the slopes. Serra da Aboboreira is then a landscape of micro-landscapes presenting different conditions/ challenges to the tenacity of communities who, as we will see, dwelt differently across geographical diversity and time.

\section{Coexistences and landscape(s) at Serra da Aboboreira (North Portugal) in between $2500 \mathrm{BC}$ and $1000 \mathrm{BC}$}

Serra da Aboboreira is located in the Atlantic subregion (see Chapter 3). During the late 1970s and 1980s, a research project developed by the University of Porto focussed on the excavation of several prehistoric sites, dating from at least the 5th millennium $\mathrm{BC}$ to the beginnings of the 1st millennium $B C$ (that is, from the Neolithic until the end of the Bronze Age). The diversity of sites, including megalithic monuments, flat pit burials, settlements, and the different studies (carbon dating, for example) allowed the construction of a chronology for this area which is still used as a reference point for the Iberian Northwest (Jorge, S.O. 2000; 2003; Jorge, V.O. 1989; 1991; 1995; Lopes and Bettencourt 2017). A Neolithic monumental necropolis, centred on the top of the mountain, was first used in the 5th millennium $\mathrm{BC}$ and grew throughout the 4th millennium BC. This construction resulted in a landscape marked by several mounds of different dimensions in dialogue with the rocky granite outcrops framing this complex scene. Under the mounds there is a diversity of hidden architecture (closed or opened chambers and passage graves, for example). The construction of the landscape of these mounds appears to have ended between the middle of the 4th millennium and the first half of the 3rd millennium $\mathrm{BC}$, although the old monuments continued to be reused throughout this period and beyond (Jorge, S.O. 2000; Lopes and Bettencourt 2017).

During the second half of the 3rd millennium $\mathrm{BC}$ construction of new monuments restarted. Two of 
these monuments are double cist chambers covered by mounds and containing individual or restricted numbers of inhumations. At one of the monuments, Chã de Carvalhal 1, the grave goods included with the burial comprised bell-beaker fragments and an assemblage of copper tanged daggers and Palmela points (Cruz 1992). The other monument, Meninas do Castro 4, was very dilapidated but contained a silver spiral (Jorge 1983). Slightly later, during the transition from the 3rd to the beginning of the 2nd millennium BC, a third grave, Outeiro de Gregos 1, was constructed next to an earlier monument. This cairn is almost invisible in the landscape, yet it contained an individual burial with fragments of an undecorated tronco-conical vessel and a silver spiral (Jorge 1980). These three monuments are new architectural devices in a space where construction had stopped at the beginning of the 3rd millennium $\mathrm{BC}$. In addition, they also present unfamiliar funerary practices, with individual or restricted numbers of inhumations, containing differentiated grave-goods (ceramics and metal). Thus, during this period there is a coexistence between constructions, suggesting different practices and worldviews: a coexistence which reasserts the traditional landscape as a meaningful and active element within the new funerary practices.

The necropolis of the Serra da Aboboreira occupies a relatively restricted space, integrating, side by side, collective tombs built in the Middle/Late Neolithic, and individual tombs from the Late Chalcolithic/Early Bronze Age (to use classic designations). Certainly, the burial landscape has changed over time, but the memory of an ancient world was strong enough, for example, to justify the construction of a cairn, at the end of the 3rd or the beginning of the 2nd millennium BC, a few metres from a Neolithic monument. And, by doing so, lay claim to Neolithic burial traditions - as if the necropolis of Neolithic ancestors was fundamental to legitimating the social change reflected in these new inhumations. Within the topology of these new constructions, we may see that these communities were deliberately connecting to this ancient space, using the memory of the old monumental landscape to link to this new way of being (Jorge, S.O. 2000; Lopes and Bettencourt 2017).

The burials of the second half of the $3 \mathrm{rd} /$ beginning of the 2nd millennium $\mathrm{BC}$, despite being part of a social apparatus promoting individualised burials, respect the traditional/collective locus for memory. And, from that point of view, they are perpetuating a world that is at an end. In a sense, this coexistence, and its topology, tell us a story which is not about collapse nor a linear continuity nor a disruptive change. This is a coexistence referring to cultural diversity, it opens up the possibility of asking how a worldview developing in the 2nd millennium converses with an ancient, and ending, Neolithic tradition. This coexistence enables us to think again about McFadyen's narrative on tenacity; and how communities' situated knowledge of a landscape relates to the dialogue between cultural differences. The analysis and discussion of this coexistence contribute to a narrative about the care of a landscape, about the conditions under which a cultural turn occurred.

Only in the first half of the 2nd millennium BC do we have consistent data to argue for a profound change in Serra da Aboboreira. The locus of this change is no longer the top plateaus, but the slope platforms. On one these platforms is located Bouça do Frade, a pit settlement inhabited during the middle of the 2nd millennium BC (although we suspect that it was occupied for the first time a little earlier) and the beginning of the 1st millennium BC (Jorge, S.O. 1988). Nearby, and also dating from the beginning of the second half of the 2nd millennium BC, there is a necropolis, Tapado da Caldeira, in which the burial architecture is also made through negative structures; there are no mounds covering the individual inhumations. Only four burials were dug, three corresponding to adult inhumations, and one to a child. Each grave contained a differently decorated, entire ceramic vase (one of which was a beautiful Cogotas I pot, suggesting social contacts with the northern Meseta). It should also be noted that in the last quarter of the 2nd millennium $B C$ a pot without decoration was deposited within a small depression in one of the graves. This pot may be associated with a funerary cremation practice dating from the beginning of the Late Bronze Age. If so, from the middle of the 2nd millennium BC the Tapado da Caldeira burials mark the shift in focus far away from the Neolithic necropolis at the top of the mountain (Jorge, S.O. 1980; 2000; Lopes and Bettencourt 2017).

From the middle of the 2nd millennium BC onwards, Tapado da Caldeira is then a new burial space, constructed by flat pits (without mounds) and associated with ceramic vessels, but not metal objects. In addition to this, we should mention that there is no spatial differentiation between the burials and the pit settlement. While it is true that we cannot ignore the possibility of the long reuse of the Neolithic necropolis, it is also true that in the Middle Bronze Age the community burial locus moved to a new space, making a topological/symbolic system with the Bouça do Frade settlement. In this way, the ideology of individuality expressed by the burial contexts of the mid 2nd millennium BC at the Serra da Aboboreira coincides with a real displacement of burial contexts. It participates in a much broader cultural turn, whose contours are not confined to social burial practices, but to a whole new way of producing a landscape.

The analysis of the coexistences between the Neolithic and Bonze Age worlds allows us to rethink the narrative we can create around this landscape. Instead of a linear 
sequence organised by periodisation and a narrative shaped by the idea of material (technical) progress, we can create a narrative exploring periodisation as a means of discussing the singularity of a landscape and its situated knowledges. By exploring the coexistences, we can get closer to the singularity of the archaeological data and use this singularity in the construction of a narrative (Pluciennik 1999; Gomes 2020). From this perspective, we speak not of a moment of transition between different chronological periods, but a social dynamic in which the topology of burial contexts stages a cultural dialogue: a material dialogue made through the reactivation of an ancient landscape, and, consequently, updating the novelty of funerary practices. In other words, it is a narrative situating things, and their knowledges, and talking of how they may have turned and altered the world under which they emerged.

\section{Final remarks}

In reading the following chapters, it will be seen that, with the exception of McFadyen and Luz, the authors roam on the macro-scale and opt for linear sequences. Such approaches present an overarching picture of historical processes whose variability makes us understand the complexity of the themes and diversity of the perspectives that can be raised. Partly as a result of this option (large scales, linear periodisations), individual burial contexts appear and (explicitly or implicitly) are seen as hegemonic indicators of cultural change and rupture, displacing the monumentality of the previous era. And yet, a small- or medium-scale investigation may lead to the observation of human intervention in the landscape as a complex system of balance/disruption that generates tradition and innovation. Regarding the consensus we mentioned at the beginning of the text, we may say that large-scale periodisations conceal the variety and ambivalence of social processes. These chronologies erase the topological nodes that can be recognised in each space, each time - they do little to explain a coexistence of differences and similarities, innovations and traditions. In our reading of the chapters we have emphasised regional particularities/asymmetries, in which the coexistence of the old and the new worlds can be explored as a means to think about the cultural turn. This is also our suggestion to the reader: try to find in each chapter other elements whose ambiguity is an exciting node to open up what has been written by this diverse and committed group of authors.

In the narrative that we have presented of the late prehistory of Serra da Aboboreira, we examined one of the fracturing points between the perspectives of Valera, Soares, and Bettencourt: the meaning of individual burials. To Valera these burials occurred at the zenith of the Neolithic social world and had little consequences for its structure; and to Soares and Bettencourt they are understood as contexts expressing a restructuring process leading to a progressive transition. Serra da Aboboreira was perceived as a landscape in which we sought to understand the topology of the contexts of individual burial compared to a landscape of Neolithic origin, emphasising how these new contexts perpetuate/update their practices; it is then a narrative of coexistence. In doing this, we realised that within a landscape we should consider two different landscapes: the monumental Neolithic necropolis at the top of the mountain which was being constructed and transformed until the beginning of the 2nd millennium; and the landscape of the slope platforms which becomes the focus of burial and domestic settlements. In the Neolithic necropolis, the disruptive character of the social practices of individual burial is even greater because it allows us to consider their occurrence as an interstice of cultural differences. An intervening space in which a 'not yet new world' and a 'no longer old world' are enhanced. A 'not yet new world' of individual burials that seem to need the knowledge and legitimacy of an earlier monumental landscape; an ancient landscape that, by welcoming new practices, marks the stage of a 'no longer old world'. As such, there is no social breakdown or transition, but a cultural dialogue made through situated (or contextual) knowledge: a knowledge of a common ancestors' landscape and a knowledge of individual burial practices. Within this cultural dialogue of knowledges the conditions for the emergence of different identities were being created - different material conditions creating modes of subjectivation, allowing different social hegemonies and landscapes.

In concluding this chapter, we should stress the need to keep looking for new ways of questioning archaeological data and interpretation. At the beginning we suggested that 'In between the 3rd and 2nd millennia: what to ask?' would be an excellent question for future research. This question would enable a situation where it was possible to discuss how each author uses their methods, conceptual frameworks, prejudices, imagination, and strategies of persuasion. Such an approach would provide an opportunity to re-imagine the circumstances and conditions under which we craft and produce knowledge about the past. After all, discussing any archaeological evidence is a matter of freedom, and only by promoting such freedom will we be able to think differently and do justice to the differences between us.

\section{Acknowledgments}

We would like to thank CEAACP - University of Coimbra for funding the seminar and this volume, and the support of M.C. Lopes. For the organisation of the seminar, we were able to rely on the helpful collaboration of A.M. 
Vaz and the support of the Faculty of Arts - University of Coimbra, to whom we also would like to express our gratitude. It was also gratifying to be able to discuss some ideas on how to study the cultural singularity of late prehistoric communities with those participating in the seminar (speakers and audience). We are also very grateful for the suggestions and guidance of the anonymous peer reviewers participating in this book. Our deepest gratitude to J. Roberts for editing and commenting on an earlier draft of this chapter; and to Zoltan Biederman for his manny suggestions. Finally, we also want to acknowledge Archaeopress for publishing this book, manly to Gerry Brisch, for reviewing the final versions of all texts, and David Davison, for managing the publishing process.

\section{References}

Aranda Jiménez, G., Montón-Subías, S. and SánchezRomero, R. (eds) 2015. The archaeology of Bronze Age Iberia: Argaric societies. New York: Routledge.

Baptista, L. and Gomes, S. 2019. Fragmentation and Architecture. Contributions to the debate on the fillings of negative structures in Baixo Alentejo's Late Prehistory. In A. Valera (ed.) Fragmentation and Depositions in pre and proto-history Portugal: 85-103. Lisboa: NIA.

Blanco-González, B., Lillios, K., López-Sáez, J.A. and Drake, B.L. 2018. Cultural, Demographic and Environmental Dynamics of the Copper and Early Bronze Age in Iberia (3300-1500 BC): Towards an Interregional Multiproxy Comparison at the Time of the 4.2 ky BP Event. Journal of World Prehistory. https://doi.org/10.1007/s10963-018-9113-3.

Cruz Berrocal, M., García Sanjuán, L. and Gilman, A. (eds) 2013. The Prehistory of Iberia. Debating Early Stratification and the State. London: Routledge.

Cruz, D.J. 1992. A mamoa 1 de Chã de Carvalhal (Serra da Aboboreira). Coimbra: Instituto de Arqueologia da Faculdade de Letras.

Gomes, S. and Baptista, L. 2017. Arquitetura e Arquivo. Contributos para uma compreensão das estruturas em negativo da Pré-história Recente das colinas entre os Barrancos da Morgadinha e da Laje (Serpa, Beja). Estudos do Quaternário 17: 89-122.

Gomes, S.A. 2020. The Practice of Writing and the Archaeological Process: Exploring the Ineffable and the Fable as Means to Create Knowledge Through Past Materials. Archaeologies. https://doi.org/10.1007/ s11759-020-09401-y.

Haraway, D. 1991. Simians, Cyborgs and Women: the Reinvention of Nature. London: Free Association Books.

Harrison, R.J. 1974. A closed find from Cañada Rosal, Prov. Sevilla and two bell beakers. Madrider Mitteilungen 15: 77-94.

Harrison, R.J. 1977. The Bell Beaker Cultures of Spain and Portugal. Cambridge, MA: Harvard University.
Ingold, T. 1993. The Temporality of the Landscape. World Archaeology 25(2): 152-174.

Jorge, S.O. 1980. A estação arqueológica do Tapado da Caldeira, Baião. Portugalia, Nova Série I: 29-50.

Jorge, S.O. 1988. o povoado da Bouça do Frade (Baião) no quadro do Bronze Final do Norte de Portugal. Porto: GEAAP.

Jorge, S.O. 2000. Domesticating the land: the first agricultural communities in Portugal. Journal of Iberian Archaeology 2: 43-98.

Jorge, S.O. 2003. Cenografias monumentais préhistóricas: tópicos para uma reflexão. In V.O. Jorge (ed.) Arquitetando espaços: da natureza à metapolis: 6383. Porto/Coimbra: DCTP/CEAUCP.

Jorge, V.O. 1980. Escavação da Mamoa 1 de Outeiro de Gregos. Serra da Aboboreira, Baião. Portugália 1 (Nova série): 9-28.

Jorge, V.O. 1983. Escavação das mamoas 2 e 4 de Meninas do Crasto. Serra da Aboboreira, Baião. Arqueologia 7: 23-43.

Jorge, V.O. 1989. Arqueologia social dos sepulcros megalíticos atlânticos: conhecimentos e perspectivas actuais. Porto, Rev. Fac. Letras, IIa Série, vol. VI: 365-443.

Jorge, V.O. 1991. Necrópole pré-histórica da Aboboreira (distrito do Porto). Uma hipótese de diacronia, Homenagem a J.R. dos Santos Júnior: 205-213. Lisboa: I.I.C.T.

Jorge, V.O. 1995. Late Prehistoric Funerary Mounds in Northern Portugal as Indicators of Social Complexity. In K.T. Lillios (ed) The Origins of complex societies in Late Prehistoric Iberia: 140-152. Ann Arbor, MI: International Monographs in Prehistory.

Lillios, K. 2019. The Emergence of Ranked Societies: The Late Copper Age to Early Bronze Age (2500-1500 $\mathrm{BCE})$. In The Archaeology of the Iberian Peninsula: From the Paleolithic to the Bronze Age: 227-293. Cambridge World Archaeology. Cambridge: Cambridge University Press (doi:10.1017/9781316286340.007).

Lopes, S.S. and Bettencourt, A.M.S. 2017. Para uma periodização da pré-história recente do norte de Portugal: da segunda metade do $4^{\circ}$ milénio aos finais do $3^{\circ}$ milenio AC, Arqueologia em Portugal/2017 - Estado da Questão - Actas do II Congresso da Associação Portuguesa de Arqueólogos: 467-487. Lisboa: AAP.

Lopes, S.S. and Gomes, S. 2018. Seminário Internacional Entre o 3. e o 2. milénio AC: Que tipo de viragem? - PréAtas. Coimbra, Portugal: CEAACP - Centro de Estudos em Arqueologia, Artes e Ciências do Património.

Meller, R., Risch, Jung, R. and Arz, H.W. (eds) 2015. 2200 $B C$ - A climatic breakdown as a cause for the collapse of the old world? 7th Archaeological Conference of Central Germany. Tagungen des Landesmuseums für Vorgeschichte Halle 13(1-2). Halle [Saale].

Müller, J., Hintz, H. and Wunderlich, M. (eds) 2019. Megaliths, Societies, Landscapes. Early monumentality and social differentiation in Neolithic Europe. Frühe 
Monumentalität und soziale Differenzierung 18. Vol. 3/3. Bonn: Verlag Dr Rudolf Habelt GmbH.

Pluciennik, M. 1999. Archaeological narratives and other ways of telling. Current Anthropology 40: 653678.

Schubart, H. 1971. O Horizonte de Ferradeira: Sepulturas do eneolítico final no Sudoeste da península Ibérica. Revista de Guimarães 81(3-4): 189-215.

Schubart, H. 1973. Las alabardas tipo Montejicar. Estudios dedicados al Prof. L. Pericot: 247-269. Barcelona: Univ. de Barcelona.
Schubart, H. 1975. Die Kultur der Bronzezeit in Sudwesten der Iberischen Halbinsel. Berlin: Walter de Gryter \& Co.

Soares, J. and Silva, C.T. 2016. Bronze Médio do Sudoeste. Indicadores de complexidade social. In A.C. Sousa, A. Carvalho, C. Viegas (eds) Terra e Água. Escolher sementes, invocar a Deusa (Estudos em Homenagem a Victor S. Gonçalves): 359-384. Lisboa: UNIARQ.

Valera, A. (ed.) 2019. Fragmentation and Depositions in pre and proto-history Portugal. Lisboa: NIA. 


\title{
Chapter 2
}

\section{The Northwest Iberian Peninsula Between the Late 3rd Millennium and Early 2nd Millennium BCE as a Mosaic of Cultural Identities}

\author{
Ana M.S. Bettencourt \\ Researcher at the Landscapes, Heritage and Territory Laboratory - Lab2PT and Assistant Professor at \\ the Department of History, University of Minho, Campus de Gualtar, 4710-059 Braga, Portugal. \\ E-mail: anabett@uaum.uminho.pt
}

\begin{abstract}
The Northwest Iberian Peninsula is not a uniform region. Geographers have divided it into two main biogeographic sub-regions: Atlantic and Mediterranean, each with its own characteristics, in terms of geomorphology and climate. The perception that these two sub-regions have distinct identities since, at least, the first half of the $3 \mathrm{rd}$ millennium BCE, i.e. since the Chalcolithic period, has led us to analyse separately developments in the last quarter of the 3rd millennium BCE, which is viewed as a key period for understanding the emergence of the Bronze Age.
\end{abstract}

During the Early Bronze Age new settlement strategies emerged in the Atlantic sub-region, associated with the appearance of innovative pottery shapes and decorations, resettlement of high-altitude areas for burial in small cairns, circulation of new prestigious metallic icons, the emergence of new styles of rock art, such as engravings of dozens of halberds, the emergence of the phenomenon of structured depositions of metallic objects, such as the deposits of halberds, or halberds and daggers, and, consequently, new social relationships, new power structures and new places for negotiating social relations, which revealed significant structural changes compared to Chalcolithic communities.

In the Mediterranean sub-region, despite new locations for certain settlements, changes seem to have occurred across a broader timeframe, including the abandonment of several community and ceremonial spaces - such as walled enclosures or shelters with collective depositions -, the emergence of metallic deposits, consisting of halberds, and the timid adoption of new iconographies in rock art. These are characterised by phenomena of continuity or social resistance, and reveal that, in this region, social changes and new scenarios of power or social aggregation occurred in a manner that differed from the Atlantic sub-region.

On the basis of the analysed data it seems possible to hypothesise that, during the last quarter of the 3rd millennium BCE, together with the phenomena of social resistance and permeability to new developments, the Northwest Iberian Peninsula was subjected to multiple and distinct influences that spawned the development of a mosaic of societies, apparently united and standardised by generalised phenomena.

The factors that contributed to this change were multiple and distinct in each of the two sub-regions. This includes important external factors, such as the climate conditions in the middle of the 3rd millennium BCE and events that occurred during the second half of this millennium, that had distinct repercussions on the two sub-regions; greater or lesser permeability to Atlantic contacts; 'dismantling' of supra-regional exchange networks with southern regions, as a result of social upheavals in the Southern Mediterranean. In terms of internal factors, it is worth highlighting the capacity for resilience and adaptation to changes. Phenomena such as the migration of populations of Pontic-Caspian origin during the second half of the 3 rd millennium BCE, revealed by DNA studies of human remains from the South, Southeast, and Southwest Iberian Peninsula, are not proven for this region, and therefore will not be taken into account.

Keywords: Northwest Iberian Peninsula, sub-regions, transition from the 3rd to the 2nd millennium BCE, continuity or change?

\section{Introduction}

This contribution aims to identify the changes that occurred in the Northwest Iberian Peninsula in the second half of the 3rd millennium BCE in order to identify the moment of possible ideological and social changes that led to a new chronological-cultural stage: the Early Bronze Age (EBA), compared to the previous period, the Chalcolithic Age (CA). The study will be carried out taking into account changes in population, pottery assemblages, funerary habits and contexts, rock art, and changes in supra-regional exchange networks. The existing data for this stage are uneven in terms of the quantity and quality of information, and differ between the two sub-regions. There is also no systematic radiocarbon dating programme that makes it possible to specify much of the known data. The holistic discourse that is intended herein will therefore only enable interpretations using a broad scale of analysis, with the reductionism that this implies.

The Northwest Iberian Peninsula is not a uniform region. Geographers have always divided it into two major biogeographic sub-regions: Atlantic, with an Atlantic influence, and Mediterranean, with a continental influence, each with its own characteristics in terms of 


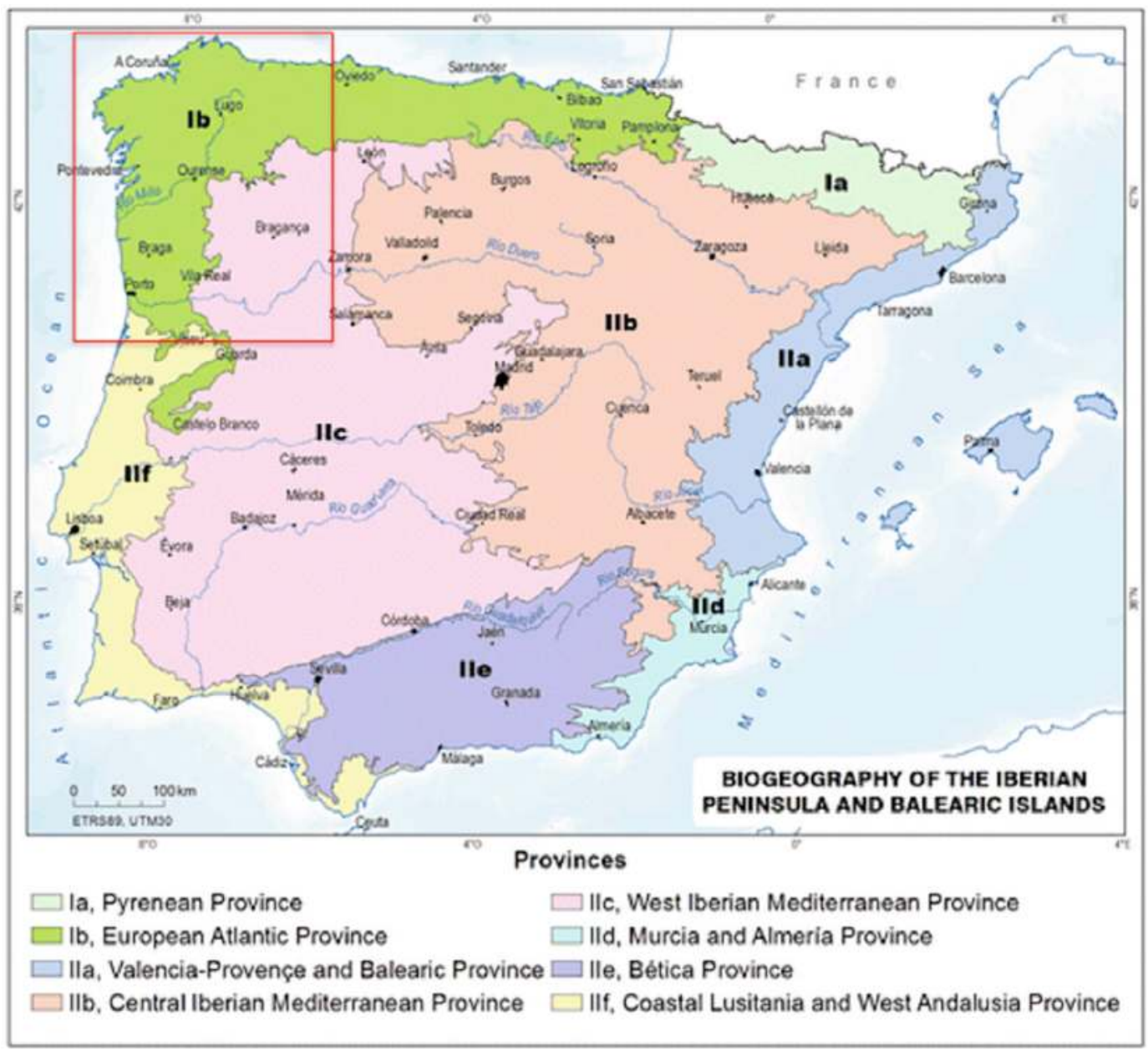

Figure 1. Representation of the Biogeographic Units of the Iberian Peninsula with North-western Iberia represented inside the square (Rivas-Martínez et al. 2017, adapted).

geomorphology and climate. The perception that there are distinct identities in these two sub-regions since, at least, the first half of the 3rd millennium BCE (Lopes and Bettencourt 2017), corresponding to the period termed the Chalcolithic period, led us to analyse the proposed theme separately for each sub-region.

\section{The Northwest Iberian Peninsula}

The Northwest Iberian Peninsula can be divided into two geographic sub-regions: a) the Atlantic sub-region, open to Atlantic influences, to the west and north, with a coastline that is marked by numerous fjord-like estuaries (rias) (that still exist in the northernmost zone and in the southernmost zone, in the Portuguese territory) ${ }^{1}$ and $b$ ) the Mediterranean sub-region, more inland and with a Mediterranean climate, separated from the Atlantic sub-region by the eastern mountains of Galicia (NW Spain), and the mountain ranges of

\footnotetext{
1 It should be noted that Martínez-Cortizas et al. (2009), inter alia consider that during the period of this study, due to conditions of neo-glaciation and greater dryness, the coast would have had more inlets and lagoons, thereby enabling the exploitation of salt.
}

Padrela, Alvão, Marão, Montemuro, and Caramulo in North Portugal.

The geographic relief of the Atlantic sub-region resembles a natural amphitheatre, stretching from the coast to the interior (Ferreira 2005), interrupted by valleys running in South-North, East-West, and Northeast-Southwest directions, that constitute true circulation corridors - such as the Mandeo, Anllóns, Xallas, Tambre, Ulla, Lérez, Minho, Lima, Cávado, Ave, and Douro rivers, and the Sousa, Tâmega and Paiva subbasins, tributaries of the Douro.

The Mediterranean sub-region is characterised by very flat plateaus that are part of the Meseta Central, intersected by more or less deep valleys and important tectonic depressions, such as those in Vilariça and Longroiva, which correspond, in part, to the western end of the plateaus of Castilla la Vieja, in Spain.

The Atlantic sub-region (Asturias, westernmost area of Galicia and North Portugal) is generally humid, with several climatic nuances due to the greater or 
lesser exposure to humid oceanic winds and high altitudes (Lautensach 1967). The Mediterranean subregion (Southeast Galicia, Trás-os-Montes and Beira Transmontana) has dry summers and a Mediterranean climate, with continental influence, although Southeast Galicia remains more humid, notwithstanding the higher altitude (Lautensach 1967) (Figure 1).

\section{The cultural background}

To understand the changes that occurred in the transition from the 3rd to the 2nd millennia BCE, it is necessary to characterise the communities that preceded it, i.e. those that existed from the end of the 4th millennium BCE until the mid/third quarter of the 3rd millennium BCE, classified in this text as the Chalcolithic period.

\subsection{Chalcolithic identities}

This period has been studied in greater depth in the Mediterranean and Atlantic sub-regions of Portugal and in some parts of the Atlantic sub-region of Galicia (Spain). Based on the data, two main identity-based zones have been identified ${ }^{2}$ that seem to articulate with the two aforementioned biogeographic regions: the Mediterranean and Atlantic, materialised by different decorative matrices inscribed on the pottery assemblages (Jorge, S. 1986; Lopes and Bettencourt 2017), and also by the symbols engraved in the different styles of rock art (Atlantic and Schematic), which are presumably associated to different forms of social organisation.

In the Atlantic sub-region, from the southern section of the province of A Coruña, through the southwest of Galicia (Fábregas Valcarce 2001) to the Douro Littoral, the dominant type of pottery is the Penha-type incised/ impressed pottery, at least by the mid 3rd millennium BCE, with metope-like decorative organisations (Jorge,

\footnotetext{
${ }^{2}$ With antecedents in the Neolithic era, herein assumed as a period that terminated at the end of the 4th millennium BCE. During this period, in the Atlantic sub-region of the Northwest Iberian Peninsula there were well-established links with the rest of Western Atlantic Europe. This can be seen in the circulation of techniques, ideas and beliefs that were at the basis of the construction of major megalithic monuments, in stone and earth, for the deposition of the dead and stone memorials for the living (standing stones); in some engraved or painted motifs on megalithic slabs or ceramic containers (Cassen and Vaquero Lastres 2000, Cassen et al. 2019, inter alia); in the circulation and importance of specific green rocks used for the manufacture of objects (Fábregas Valcarce et al. 2012); in the so-called Classic Atlantic rock art (according to the hypothesis defended by several authors, such as Alves 2003; 2009; Bettencourt 2013; Cardoso 2015; Alves and Carvalho 2017; inter alia). Some of these identity-based expressions would have been introduced inland, along the major rivers, such as the Douro and its sub-basins. Examples include 'funerary' megalithic monuments, which spread asymmetrically in the midst of indigenous groups, that were apparently distinct from the coastal areas, still poorly studied, but something which is revealed, for example, in terms of the quantities of artefacts deposited within funerary megalithic monuments and their rarity in the easternmost zones.
}

S. 1986; Lopes and Bettencourt 2017), as well as a greater profusion of Classical Atlantic rock art, that has persisted since the Neolithic era (Alves 2003). In the Mediterranean sub-region, from the easternmost section of the province of Ourense to the Alto Douro, including the northeast section of Trás-os-Montes, combed pottery with horizontal or wavy decorative organisations, and some Schematic rock art motifs ${ }^{3}$ prevails (Lopes and Bettencourt 2017). However, it is possible to note permeability between these different identity-based zones, especially along the Douro and its tributaries - true natural corridors for the circulation of people, ideals, materials, objects and techniques.

In each of the identity-based areas, evidence indicates a strong exchange with more southern areas, both along the coast and across the interior circulation corridors.

For example, Penha-style pottery and Atlantic-style rock art are found, at least, up to the Mondego basin, not as predominant elements, but as exceptions for example, the Tapada do Espinheiro site and the presumed enclosure of Chãs, both in Cantanhede, Coimbra (Bettencourt 2005; Cruz 2005; Cruz et al. 2011). ${ }^{4}$ This permeability is also revealed by interior circulation corridors, between the northeast of Trásos-Montes, the Alto Douro and Beira Alta, through combed iconographies, where they also constitute exogenous elements (Valera 2007). This widespread permeability implies well-established, supra-regional exchange networks, in an area of the Iberian Peninsula that is assumed to be relatively peaceful, at least in the first half of the 3rd millennium BCE.

\subsection{Supra-regional interactions}

This period was also marked by a large number of foreign influences, from south to north, wherein the Northwest Iberian Peninsula became more 'influenced' by artefacts, materials, techniques, and ideologies of southern origin. This phenomenon was also linked to the major social and economic dynamism that occurred in the south of the Iberian Peninsula (Nocete 2001; Nocete et al. 2005; Cruz Berrocal et al. 2013; Gilman 2013; Soares 2016; García Sanjuán 2017; Valera 2019; among others).

These influences led to the emergence of walled enclosures, which were more common in the eastern section of the Northwest Iberian Peninsula, for example, Castelo Velho de Freixo de Numão (Jorge S. 1994; 2014; Lopes 2019) and Castanheiro do Vento (Cardoso 2007; Vale 2011), both in Vila Nova de Foz Côa, Guarda; Crasto

\footnotetext{
${ }^{3}$ Still little individualised from its Neolithic background.

${ }^{4}$ This is the closest area to the north, rich in flint raw material, which may justify the exchange with the northernmost regions (Cruz et al. 2011).
} 
de Palheiros, in Murça, Vila Real (Sanches 2008), and other sites, as identified in the archaeological fieldsurveys undertaken by Cardoso (2007). Further north, the same phenomenon is also identified at El Pedroso, Trabazos, Zamora (Delibes de Castro et al. 1995), on the border with Portugal. In the most western façade of the Northwest Iberian Peninsula, there are also walled enclosures, such as those located at Chás, Oimbra, Ourense (Gómez Fernandez et al. 2004), ${ }^{5}$ Mesa de Montes, Cangas do Morrazo, Pontevedra (Fábregas Valcarce 2010: 111) and Sola I, Braga (Bettencourt 2000). Complex ditched enclosures are also found, for example at Forca, in Maia, Porto (Valera and Rebuge 2008; Bettencourt 2010b; 2013; Bettencourt and Luz 2013; Loureiro 2017) and Montenegro, ${ }^{6}$ in Moaña, Pontevedra (Gianotti and Cancela 2005), although the latter has been related with possibly funerary events, or with timber circles of Atlantic tradition (Gianotti et al. 2011) (Figure 2).

It was also within the framework of these supra-regional networks that the emergence of copper mining and metallurgy was introduced in the Northwest Iberian Peninsula. The respective data are documented by analyses of environmental archives that have detected evidence of regional atmospheric pollution and the contamination of soils by heavy metals, as a result of this activity, conducted at La Molina mire, Salas, Asturias, in Northern Spain, throughout the 3rd millennium BCE, although with greater impact in the second half of the 3rd millennium BCE (4030-3700 BP) (Martínez Cortizas et al. 2015). This highlights another former copper mining area in western Asturias, because the isotopic signature of ores from copper mines in Northern Spain, such as El Milagro, in Riosa, located $35 \mathrm{~km}$ south-east of La Molina, and El Aramo, in Cangas de Onís, 100 km east, is clearly different from that of La Molina (Martínez Cortizas et al. 2015: 403). El Aramo seems to have started its activity between 2500-2400 BCE, although there was a first occupation between 2679-2470 BCE (88.8\%) ( $4045 \pm 40 \mathrm{BP})$ in the settlement of La Campa les Mines, located outside the mine (Blas Cortina et al. 2013).

Other evidence of copper metallurgy are the first copper crucibles and waste, and a possible fragment of tuyere in some Chalcolithic settlements, as well some flat axe stone moulds from the westernmost region (Jorge 1986; Comendador Rey 1998) and evidence of crucibles, fragments of tuyere slag and moulds linked to the production of several copper objects in settlements

\footnotetext{
${ }^{5}$ On the right bank of the Tâmega basin, therefore more connected to the Atlantic sub-region.

6 This is a unique site, with a large enclosure of about $20 \mathrm{~m}$ in diameter, delimited by a small ditch, in an area with scattered accumulations of materials. It was excavated in an open area (Tabarés Domínguez and Baqueiro Vidal 2005). The area of the enclosure with metope-style Penha-type pottery provided a date of $4120 \pm 40 \mathrm{BP}$ (2872-2576 BCE). An area further west at a lower level, in another sector, provided a date of $3813 \pm 52(2462-2134 \mathrm{BCE})$ with another type of pottery.
}

and enclosures in the easternmost sub-regions (Sanches 1997; Delibes de Castro etal.2005; Vieira 2015). Associated with this activity or exchanges is the manipulation of copper artefacts, namely flat axes, chisels, sticks, saws, Palmela points, and some small daggers that have been found in different contexts (settlements, enclosures, funerary monuments, in fissures of outcrops engraved with rock art) as highlighted by several authors (Jorge, S. 1986; Cruz 1992; Alves and Comendador Rey 2009; Lopes and Bettencourt 2017, among others).

The expansion or adopted model of maritime and linear and geometric Bell Beaker pottery almost certainly began in this period, as well as the associated rites, given the antiquity of these containers in southern locations (Cardoso and Soares 1990-1992; Cardoso 2005a; Cardoso 2014-2015), based on some radiocarbon dates of findings in the North of Portugal (Barbosa 1999; Sanches 20002001; Jorge, S. 2002; Jorge, V. et al. 2002; Bettencourt and Luz 2013; Teixeira 2019), and in more northern areas of the Northwest Iberian Peninsula, that do not exceed the third quarter of the 3rd millennium BCE (Alonso Mathías and Bello Díeguez 1995; Fábrega Valcarce et al. 2007; Bradley et al. 2015). ${ }^{7}$ Another manifestation of southern influence is the appearance of new symbols, such as ocular motifs, which reflect the circulation of a supra-regional ideological background ${ }^{8}$ and that are found, especially, in the Mediterranean sub-region, either in ceramic containers, e.g. S. Lourenço, Chaves (Jorge, S. 1986); Castelo Velho de Freixo de Numão, Vila Nova de Foz Côa (Lopes 2019); shelter 1 of Buraco da Pala, in Mirandela (Sanches 1997); or in painted rock

\footnotetext{
Note the international Bell Beaker, found in the terrace in front of the Cova do Mouro, Zamora (Bradley et al. 2005), dated from $4022 \pm 27$ BP (2584-2472 BCE), and the maritime and linear Bell Beaker found in the tomb of La Sima (Soria), dated from 2460-2270 (Garrido Pena et al. 2006). It should also be borne in mind that, according to Fábregas Valcarece $(2001 ; 2010)$, the presence of a bell tower does not imply a rupture in the Chalcolithic sites of Galicia, such as As Forcadas and Monte dos Remédios. In fact, this has been repeated in several works by authors that synthesise this phenomenon or the communities of the 3rd millennium BCE in North Portugal, with well-contextualised data, such as Jorge, S. (1986), Sanches (1997), Barbosa (1999), Sanches (2000-2001), Jorge, S. (2002), Jorge, V. et al. (2002), Bettencourt (2011), and Lopes and Bettencourt (2017), against a certain obsession of a small number of authors, who, based on unreliable data in stratigraphic terms, systematically and uncritically attribute these pottery items found in Galicia to the Early Bronze Age.

${ }_{8}^{8}$ However, the Northwest Iberian Peninsula continues to be part of the network of Atlantic contacts, expressed now in a more tenuous way. This seems to be the case with the fragments of cordedimprinted Bell Beaker containers that occur mainly in Galicia (Suarez Otero 2011) and, to a lesser extent, in North Portugal (Jorge, S. 2002; Bettencourt 2011; Bettencourt and Luz 2013). One can refer, for example, to those deposited in the rock shelter of Arca dos Penedos, Ourense (Eguileta et al. 1993-1994); in older megalithic funerary monuments, e.g. Forno dos Mouros (Toques, A Coruña), Alto de San Cosme (Mos, Pontevedra) (Prieto Martínez 2011) and Monte dos Marxos (Rodeiro, Pontevedra) (Suárez Otero and Lestón 2005); in the presumed 'settlements' of A Fontenla (Moaña, Pontevedra) and As Gándaras de Budiño (O Porriño, Pontevedra) (Suárez Otero 1995; Prieto Martínez 1999) and in the enclosures of (Maia) (Bettencourt and Luz 2013), Castelo Velho de Freixo de Numão (Jorge, S. 2002) and Castanheiro do Vento (Bettencourt and Luz 2013).
} 

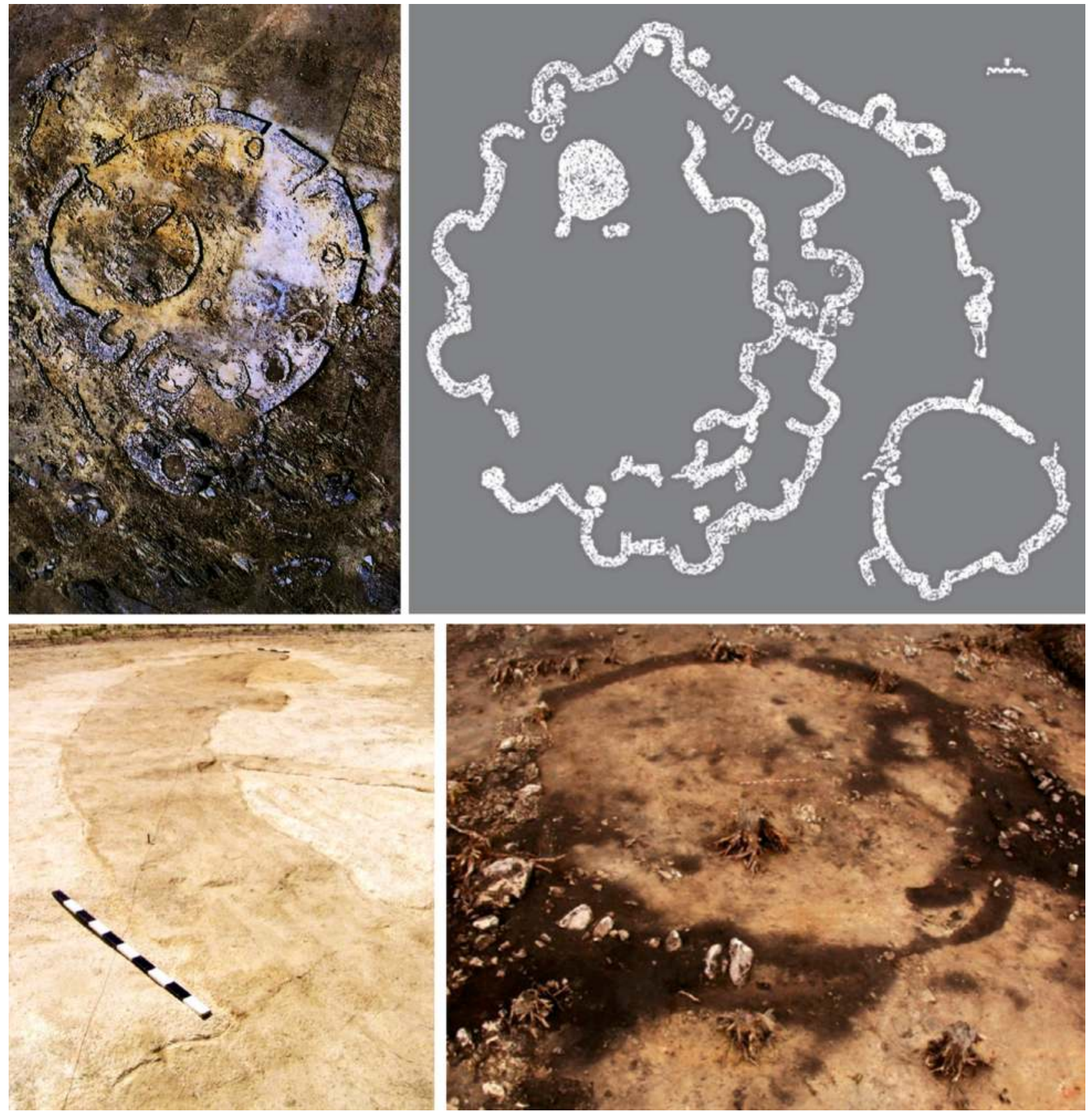

Figure 2. Types of Chalcolithic enclosures. Top left: walled enclosure of Castelo Velho de Freixo de Numão (Jorge 2005); top right: and Castanheiro do Vento (Cardoso 2007, adapted); bottom left: ditched enclosure of Forca (Bettencourt 2010b); bottom right: ditched enclosure of Montenegro (Gianotti et al. 2011).

shelters, e.g. Serra de Passos 1/Regato das Bouças 15, Serra de Passos 3/Regato das Bouças 11 (Figueiredo 2013; Sanches et al. 2016), Regato das Bouças 1 and 2, all in Mirandela (Sanches et al. 2016), and Pala de Cabras, in Casaio, Carballeda de Valdeorras, east of Galicia, still under study (Figure 3). In the Atlantic sub-region, examples have been found in settlement and burial contexts, e.g. Chã do Castro, in Amares, Braga (Jorge 1986); Mount of Penha, in Guimarães (Pina 1928) and O Buriz mound (Rodríguez Casal 1990).

This permeability to innovation seems to extend to the countless stelae with features similar to those of the interior and southern zones of the Iberian Peninsula, mainly located in the Mediterranean sub-region of the Northwestern Iberian Peninsula, with rare extensions to the Atlantic sub-region. This seems to be the case with the important enclosure of stelae in Cabeço da Mina, in Vila Flor (Sousa 1996; 1997; Sanches 1997; 2011; Jorge, S. 1999b; Lopes and Bettencourt 2017), where weapons are absent and present '....great stylistic schematism, (in addition to) anatomical motifs (eyes, nose, mouth, arms, possibly legs and sex) and complementary motifs (belts, necklaces, insignia, etc.' (Lopes and Bettencourt 2017: 14). The chronological assignment of this enclosure to the Chalcolithic period is also based on the 

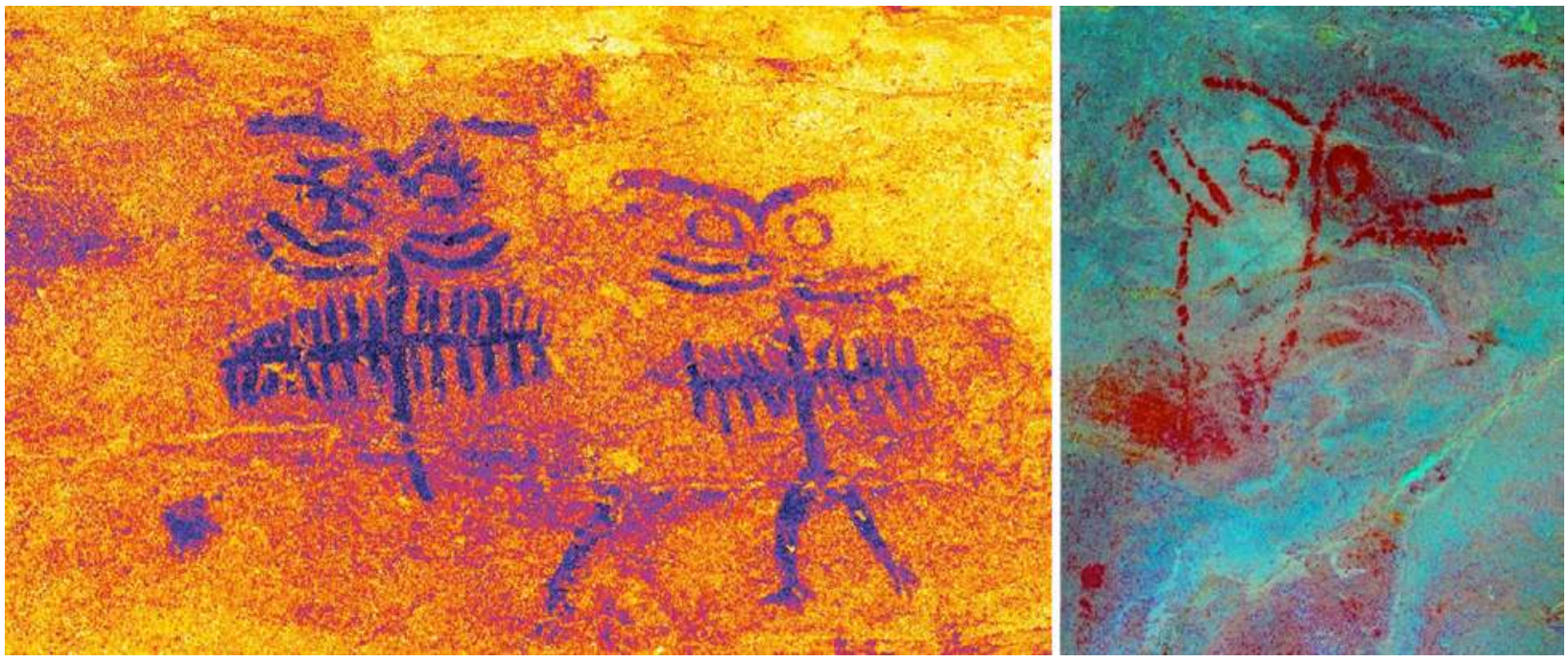

Figure 3. Painted rock shelters with ocular motifs. Left: rock shelter of Regato das Bouças 11, Serra de Passos, Murça, Mirandela, Portugal (Source: https://nationalgeographic.sapo.pt/historia/actualidade/ 685-a-galeria-da-serra-dos-passos). Right: Pala de Cabras, Carballeda de Valdeorras, Galicia, Spain (source: Sputnik Labrego http://www.vinosycaminos.com/texto-diario/mostrar/ 1322375/).

fact that the face sides of some of these stelae seem to resemble ocular motifs.

It is likely that in these networks of exchanges - in which people, ideas, techniques, objects and materials were traded - copper (more abundant in the south) and variscite played a significant role, especially since they would have been matters of great social importance and attributed major symbolism and properties. ${ }^{9}$ Variscite existed in the north of Aboboreira and in eastern Trás-os-Montes (Ferreira el al. 1999), as well as in the northern Meseta (Mediterranean sub-region) and in the south of Galicia (Fábregas Valcarce and RodríguezRellán 2019).

However, given the permanence of identities, alterations of exogenous origin must be related to societies that adopted and adapted new styles within the framework of a traditional cosmological universe, with greater or lesser autonomy, depending on the different regions.

\subsection{Settlements and subsistence strategies}

During this period, throughout the Northwest Iberian Peninsula there was an increase in the number of settlements. In the Atlantic sub-region, settlements

\footnotetext{
${ }^{9}$ In this regard, it is important to note the existence of a considerable number of unfinished variscite beads, at the Chalcolithic level of Buraco da Pala, in Mirandela, a factor that Sanches (1997) considers is probably linked to the mining area of Ervedosa. It should also be noted that the 75 variscite beads from Vilanova de São Pedro, in Azambuja, Estremadura, primarily derive from Palazuelo mineralisations (Odriozola et al. 2013).
}

occurred in areas of medium or low altitude, usually offering panoramic views over the surrounding irrigated valleys or coastal platforms, in places often with profusions of rock shelters or granite outcrops (Jorge 1986; Fábregas Valcarce 2001; Bettencourt 2005b; Fábregas Valcarce et al. 2007; Bettencourt 2009a; 2013; Lopes and Bettencourt 2017). Some are located in granitic alveoli, in low-lying plateaus or in low elevated hills of the coastal platform (Bettencourt 2005a; 2009a; 2013). In the Mediterranean sub-region, Sanches (1997) has divided settlements into two types: those that would have a territory with a high productive capacity in relation to agro-pastoral activities, using rudimentary technologies, and those located in 'poorer' and more rugged territories that she considered may have been complementary to the former, with more seasonal occupation.

In both sub-regions, the quantity of ceramic and lithic materials found, the existence of some stone walls (sometimes demarcating artificial platforms), or the stratigraphy reveal long periods of human occupation, thereby indicating greater sedentarisation than in the previous period.

In both sub-regions, easy access to a diversity of areas with different edaphic and topo-climatic conditions near the settlements would have facilitated rational land management of the territory for the cultivation of different types of cereals or legumes and the grazing of different types of domestic animal species. In this manner, in terms of pastoral agro-silvo activities, the communities in both sub-regions appear to have had 
well-developed sources of subsistence, complemented by hunting and gathering activities of vegetables and fruit, and seafood, in coastal areas (Sanches 1997; Figueiral and Sanches 1998-1999; Fábregas Valcarce 2001; Bettencourt 2009; 2013; Bettencourt et al. 2017b).

As a result of this increase in human activity, there was a certain regression of forestry areas around these settlements and an increase in erosion processes, also influenced by the climatic deterioration that occurred in this period (Martínez Cortizas et al. 2000), at least in the Atlantic sub-region.

In the Mediterranean sub-region, the local populations cultivated cereals, such as dress and bare wheat (Triticum dicoccum and Triticum aestivum), barley (Hordeum vulgare), legumes, such as peas (Pisum sativum) and broad beans (Vicia faba) and also flax and linseed, associated with the collection of, at least, acorns, pine nuts, tree-strawberry berries (Arbutus unedo). The opium poppy (Papaver somniferum) was also consumed (Ramil Rego and Aira Rodrigues 1993; Sanches 1997; Figueiral and Sanches 1998-1999; Sanches et al. 2007; Bradley et al. 2015). Shepherding is documented by the appearance of domestic species, such as cattle (Bos taurus or Bos sp.) and sheep/goats (Ovis aries/Capra hircus), although pig/wild boar (Sus sp.) are also found in almost all archaeological sites of this period. Wild animals, such as horse, deer, wild boar and rabbit were scarce (Sanches 1997; Cardoso and Costa 2004; Cardoso 2005b; Costa 2007; 2008).

In the Atlantic sub-region, remains of cereals have been documented, such as bare wheat (Triticum aestivum/compactum) and dress barley (Hordeum vulgare), and legumes, such as broad beans (Vicia faba). Flax (Linum sp) has also been found, but we are unable to ascertain whether it corresponds to cultivated or wild species. There were gathering activities of roasted acorns, blackberries, and wild radishes (Raphanus raphanistrum) (Ontañón Peredo 2003; Bettencourt et al. 2007b; Figueiral and Bettencourt 2007). It is worth mentioning the appearance of silene, a plant suited to dry to slightly humid soils, during the first half of the 3rd millennium $\mathrm{BCE}$, in the settlement of Bitarados, very near the coast (Figueiral and Bettencourt 2007). Remains of ovicaprines and perhaps ox indicate the breeding of cattle. Deer remains point to the consumption of wild animals (Ontañón Peredo 2003; Cardoso and Bettencourt 2008). Swine are also present (Jorge 1986). These populations also collected or hunted deer, rabbits, bustards (cf. Otis tarda) and horses (Equus caballus) (Jorge 1986; Fernández Rodríguez 2000; Fernández Rodríguez and Ortiz 2007).

\subsection{The world of the dead}

With regard to the first half of the 3rd millennium BCE, both in Portuguese and Spanish territories (Galicia and Asturias), and in the Atlantic and Mediterranean subregions, there is great invisibility of funerary contexts, with a diversity of solutions in rites and contexts and the emergence of individual graves. The latter phenomenon can be observed in the necropolis of cists used for inhumation burials, covered with small stone mounds (cairns) at Vale da Cerva, Vila Nova de Foz Côa, Guarda, in a riverside area, in the vicinity of Schematic rock art (Baptista 1983; Cruz 1998), in one cist with cremation remains in Agro de Nogueira, Melide, Lugo, also in a riverside area (Bettencourt and Meijide Cameselle 2009), and in the small burial cist in A Devesa de Abaixo, Moaña, in Pontevedra, dated 2707-2570 BCE ${ }^{10}$ (Vázquez Liz and Prieto Martínez 2016) (Figure 4).

In the Mediterranean sub-region there is documented evidence of the use of cavities for burials. Such is the case of the inhumation burial sites at Lorga de Dine, in Vinhais, Bragança (Pereira et al. 2018) and probably in Gruta de Ferreiros and Gruta Grande, in Miranda do Douro (Sanches 1992), for the materials associated to the corpses. In the same sub-region, manipulation of secondary human remains occurred in the monumental walled enclosure of Castelo Velho de Freixo de Numão (Jorge et al. 1998-1999) (Figure 4).

No megalithic monuments from this period are known in either region, perhaps with two exceptions, in the Atlantic sub-region, of an atypical earth mound in Aspra, at Caminha, Viana do Castelo, with a pit chamber and only Bell Beaker pottery as deposits (Lopes and Bettencourt 2017), and another, Lousada 5, at Xermade, Lugo where one or more corpses were deposited with incised-metope-type vessels and concave-base arrowheads (Fábregas Valcarce and Vilaseco Vázquez 2004).

Several tombs with mounds constructed mainly with stone blocks (cairns) were built in the Atlantic subregion, but only from the third quarter of the 3rd millennium BCE, apparently after an interregnum in construction. Examples include Regedoura, at Fafe (Pereira 2018), Illade 3 and Reboredo I, both at A Coruña (Vaquero Lastres 1995).

However evidence does exist of the reuse of megalithic monuments, either through architectural remodelling, such as Dombate, in Cabana de Bergantiños, in the province of A Coruña, which occurred in the first half of the 3rd millennium BCE, or its use between c. 2589-2469 $\mathrm{BCE}$, through the deposition of Bell Beaker containers (Alonso Mathías and Bello Díeguez 1995). There is

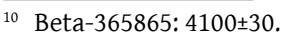



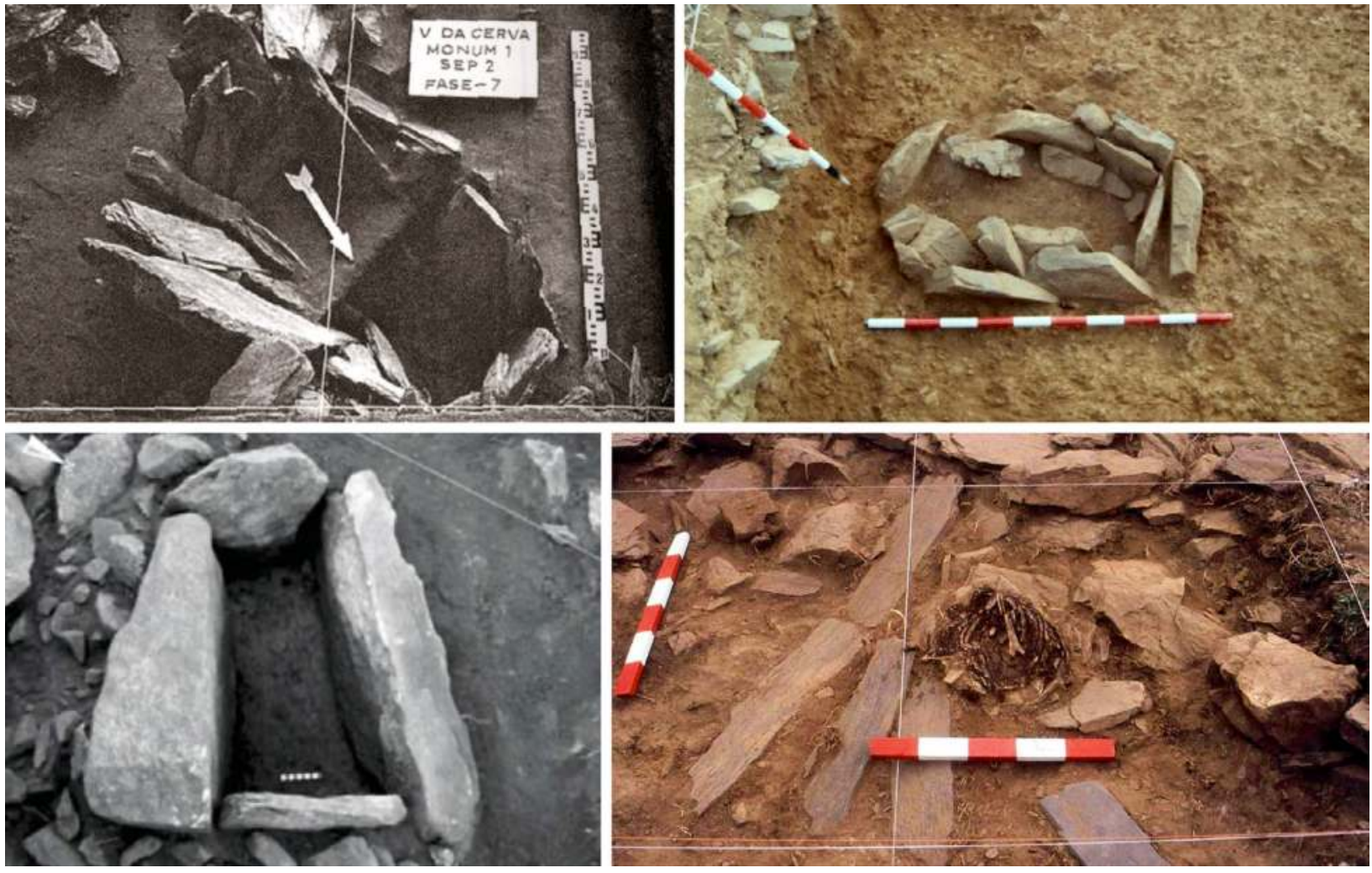

Figure 4. Chalcolithic funerary contexts of the Northwest Iberian Peninsula. Top left: cist at Vale da Cerva, Vila Nova de Foz

Côa (Baptista 1983); top right: cist at Agro de Nogueira, Melide, Lugo (Bettencourt and Meijide 2009); bottom left: cist of A Devesa de Abaixo, Moaña (Vázquez Liz and Prieto Martínez 2016); bottom right: deposition of human remains at Castelo Velho de Freixo de Numão, Vila Nova de Foz Côa (Jorge et al. 1998-1999).

also evidence of depositions of Chalcolithic vessels with incised motifs, one with ocular motifs at Monte Pirleo 5, at Buriz, Guitiriz, Lugo (Fábregas Valcarce and Fuente 1988), of containers of Penha-type tradition at Cotogrande 5, Vigo, Galicia ${ }^{11}$ (Abad Gallego 19921993), and at Mamoa da Fábrica, Viana do Castelo (Silva 2003), among other poorly contextualised data (Gómez Fernandez et al. 2004). It is likely that many instances of reuse of monuments, materialised through depositions of Bell Beaker vessels (Jorge, S. 2002; Bettencourt 2011), must have occurred, at least, from the third quarter of the 3rd millennium BCE.

In Asturias, the mine galleries of El Aramo were also used for funerary purposes, from the middle of the $3 \mathrm{rd}$ millennium BCE (Blas Cortina 2003).

In short, in this period there was a change in the social role of death, the corpse and funerary architecture, with the loss, at least systematically, of the importance of the cult of ancestors, and the end of construction of monumental buildings dedicated to the dead, alongside the development of individual burials, where bodies

$\overline{11}$ Which may also have been changed at some point in the $3 \mathrm{rd}$ millennium BCE (Fábregas Valcarce and Vilaseco Vásquez 2004). buried in large-scale dolmens or in the ancestors' territory would have been agents in the processes of appropriation and incorporation of the past in the new world view.

The new landmarks were monumental walled or ditched enclosures, within which there is recurrent evidence of structured depositions of different categories of artefacts, as at Castelo Velho (Lopes 2019), Castanheiro do Vento (Vale 2011), Castro Palheiros (Sanches 2008), and Fraga da Pena (Valera 2007), materialising a cosmogonic universe that is distinct from the Neolithic period, as has been defended for the Atlantic sub-region (Bettencourt 2009; 2013).

\section{The final quarter of the 3rd millennium BCE: the data}

The final quarter of the 3rd millennium BCE and the beginning of the 2nd millennium BCE is a difficult period to study, either because archaeological sites are difficult to find, or because many of the excavations carried out at some are sporadic and rarely published. Over recent years, and, in most cases resulting from preventive archaeology, there has been a higher number of findings from this period, accompanied by 


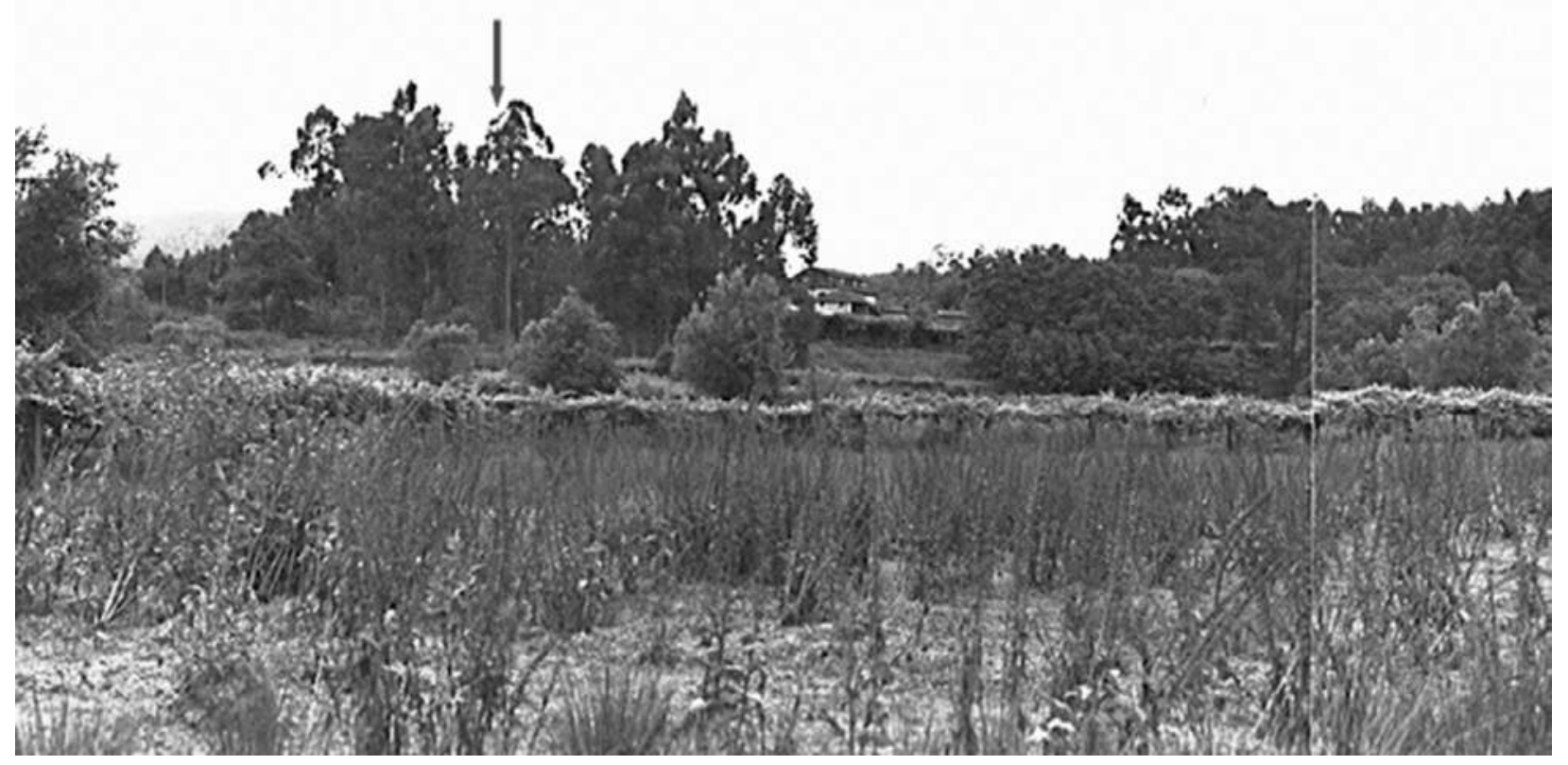

Figure 5. Hamlet of Boucinhas, Ponte de Lima, Portugal, in the Garantau valley (Bettencourt 2013).

some more or less monographic studies, which make it possible to review this situation. However, the very uneven published contributions makes it difficult to analyse this phenomenon in the Northwest Iberian Peninsula. One of the main problems is the lack of vertical stratigraphy at many excavated sites, and the premise defended by some Galician authors, such as Prieto Martínez (2011), that the existence of the Bell Beaker pottery immediately refers to this chronological stage. This impedes careful and concrete analysis of the chronological dating of many archaeological sites found on the surface, or without vertical stratigraphy. Archaeological knowledge is essentially achieved, and as a starting point, through well-contextualised data, and only on the basis of that knowledge has it been possible to analyse other contexts. This text has been written using this methodology, and although it focuses on the aforementioned period, it sometimes compares the data with the immediately preceding or subsequent historical periods, to ensure a fuller understanding of the phenomena of change and continuity.

Taking into account the two biogeographic subregions of the Northwest Iberian Peninsula, each has been studied individually, prior to comparing them in section 5 of this text.

\subsection{The Atlantic sub-region}

\subsubsection{Settlements}

In the Atlantic sub-region, the population data are equally dispersed and reveal different land occupation strategies. In a valley setting, nearby well-irrigated fields with agricultural potential, the settlements of Setepías at Cambados, Monteverdi, near the Ría de Arosa estuary (Acuña 2003; Acuña Piñero et al. 2011), of Boucinha/Regueira, at Ponte de Lima, Viana do Castelo (Bettencourt et al. 2004; Bettencourt 2010a) (Figure 5) and of Rossio, at Vale de Cambra, Aveiro, are known, wherein the latter two have pits. In the coastal zone there is a settlement at Guidoiro-Areoso, at Vilanova de Arousa, Pontevedra (López Romero et al. 2015), and the Carreço-Praia camp, at Viana do Castelo (Baptista 1992), probably associated with the exploitation of salt, due to the appearance of a shallow sink excavated in the schist, similar to many others found along the coast, although out of context (Bettencourt 1999; 2009; 2013). In high altitude areas, the mining settlement at La Campa les Mines, in Cangas de Onís, Asturias, close to the copper mines of the Sierra de El Aramo (Blas Cortina et al. 2013) was still in operation, as were the mines.

There were also settlements located in low-lying and well-irrigated areas, or in low-altitude granitic alveoli, including the examples of Poza da Lagoa/Viveiro 2, in Redondela, Pontevedra (Fábregas Valcarce 2001; 2010) and A Lagoa PA 45.04, at Toques, A Coruña (Méndez Fernández 1994; 1998). Another settlement is at Os Torradoiros, at Moaña, Pontevedra, on a spur of the gentle slope of Monte Faro de Domaio, close to a stream overlooking the Ria de Vigo estuary (Vazquéz Liz and Prieto Martínez 2016) ${ }^{12}$ (Table 1).

12 From a more recent period, although still considered to pertain to the Early Bronze Age, other settlements are known, in similar locations to those of the transition from the $3 \mathrm{rd}$ millennium to the 2nd BCE. In 
Table 1. C14 dating of settlements of the Atlantic sub-region of the Northwest Iberian Peninsula and Asturias in the late 3rd and early 2nd millennia BCE

\begin{tabular}{|l|l|l|l|l|}
\hline Site & Lab. Ref. & $\begin{array}{l}\text { Conv. Rad. Age } \\
\text { (BP) }\end{array}$ & Cal BC (2 sigma) & References \\
\hline A Lagoa P.A. 45.04 & CSIC-1000 & $3800 \pm 30$ & $2310-2140$ & Méndez Fernández 1994 \\
\hline $\begin{array}{l}\text { La Campa les Mines (El } \\
\text { Aramo) }\end{array}$ & Ua-39330 & $3723 \pm 32$ & $2206-2026(95.1 \%)$ & Blas Cortina et al. 2013 \\
\hline Carreço Praia & Thermolum. media & $3855 \pm 207$ & $2280(1865) 1450$ & Baptista 1992 \\
\hline Boucinha/Regueira & A A-63072 & $3739 \pm 50$ & $2294-2016(94 \%)$ & Bettencourt 2010a \\
\hline Rossio & D-AMS 007749 & $3764 \pm 26$ & $2234-2130(73.6 \%)$ & Unpublished ${ }^{* *}$ \\
\hline $\begin{array}{l}\text { Poza da Lagoa/Viveiro } \\
\text { 2 }\end{array}$ & UtC-5217 & $3673 \pm 34$ & $2140-1950$ & Fábregas Valcarce 2001; 2010 \\
\hline Sete Pías & Ua-21849 & $3670 \pm 45$ & $2148-1927$ & Acuña et al. 2011 \\
\hline Os Torradoiros & Beta-354143 & $3670 \pm 30$ & $2139-1956$ & Vazquéz Liz and Prieto Martínez 2016 \\
\hline Guidoiro Areoso & GrN-16108 & $4020 \pm 40$ & $2131-1886$ & $\begin{array}{l}\text { Alonso Mathías and Bello Díeguez 1997; } \\
\text { López Romero et al. 2015. }\end{array}$ \\
\hline
\end{tabular}

* The 14C dates were calibrated using OxCal 4.2 (curve IntCal 13) (Reimer et al. 2013).

** Information kindly provided by António Silva.

At almost all of these sites there is documentation of pit structures, post-holes, and small trenches, as well as some fireplaces, demonstrating that the constructions were built from perishable materials.

These are places where the pottery assemblages are well distinguished from the Chalcolithic sets, due to their shapes, decoration, and dimensions. The containers are generally larger, with shapes provided with more or less accentuated necks, S-profiles, flat bottoms, and decorations, mostly associated with plastic decoration, in particular cords. Despite revealing apparent uniformity with the interior, on the western side there are no Chalcolithic shapes or decorations, nor Cogecestype shapes and decorations that emerged in the Northeast Iberian Peninsula.

There are no, or very few, flint and flaked stone artefacts in Galicia (Fábregas Valcarce 2001; 2010) and the rest of the northern coastal area (Bettencourt 2000).

In terms of agro-pastoral activities, this period is difficult to determine, since the syntheses on plant macrorests, due to their scarcity, seem to be from the

this case, there are settlements in areas more favourable to pastoral activities, e.g. Lamas de Abade, in Santiago de Compostable, A Coruña (Martin Seijo et al. 2017c); Monte Calvo, in Baião, Porto (Marín Seijo et al. 2012; Bettencourt 2013), those located in valleys with agricultural potential e.g. A Pataqueira, in Palas de Rei, Lugo (Martín Seijo et al. 2017c), Monte de Cabanas, in Vigo, Pontevedra (Tereso et al. 2016, Martín Seijo et al. 2017b), Fraga do Zorro, in Verín, Ourense (Prieto Martínez et al. 2009; Prieto Martínez and Gil Agra 2011), Sola IIa, in Braga (Bettencourt 2000), and those on the coastal platform, e.g. Areias Altas, Porto (Luz 2010).
Early Bronze Age as well as the Middle Bronze Age, a period that spans much of the 2nd millennium BCE.

Other paleoenvironmental data for the Atlantic subregion are abundant (Ramil-Rego et al. 1998; Fábregas Valcarce et al. 2003; Muñoz-Sobrino et al. 2007; Mighall et al. 2006; Martínez-Cortizas et al. 2009; Carrión et al. 2010a; López-Merino et al. 2010a; 2012; Kaal et al. 2011) and points to a significant decrease in forest cover, which occurred throughout the Middle Bronze Age. Its cause is usually assumed to be anthropogenic, although climate deterioration could have also enhanced episodes of deforestation and erosion (Fábregas Valcarce et al. 2003; Muñoz Sobrino et al. 2005; Martínez-Cortizas et al. 2009; López-Merino et al. 2010a; Kaal et al. 2011). Nevertheless, significant regional differences have been detected (Ramil-Rego 1993; Muñoz-Sobrino et al. 2004; 2007; Kaal et al. 2011; López-Merino et al. 2012), suggesting that deforestation occurred earlier and was more intense in coastal and sub-coastal zones, as well as mainland low-to-mid altitude areas, probably due to the fact that these areas were suitable for farming or pastoralism.

\subsubsection{Funerary contexts}

There are various funerary contexts in the period under study, including both cremations and inhumations. Cremations, which existed in the Northwest Iberian Peninsula since the third quarter of the 3rd millennium $\mathrm{BCE}$, as seen in the cist of Agro de Nogueira, at Melide, Lugo (Bettencourt and Meijide Cameselle 2009), spread to other contexts, as revealed by the urn deposited 

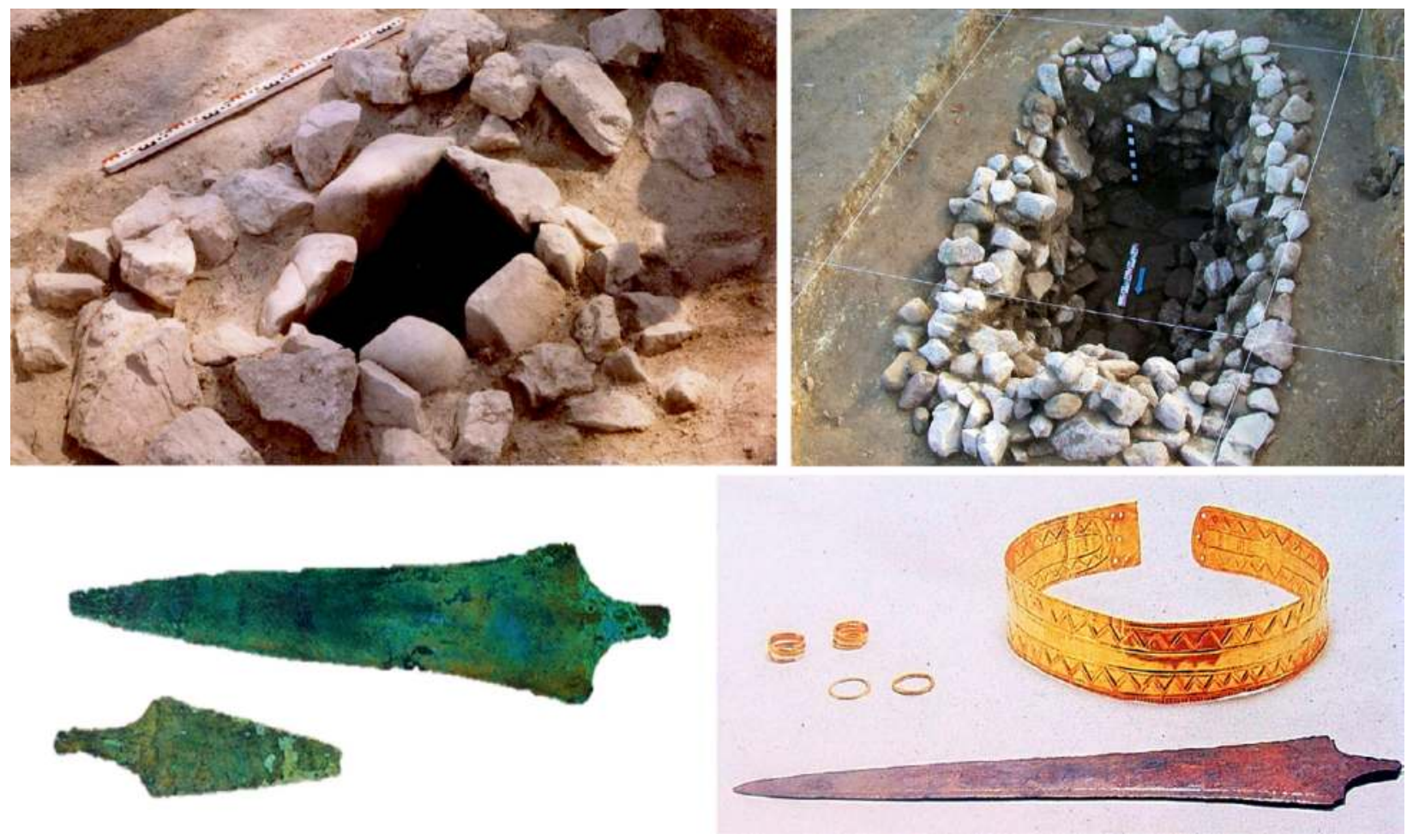

Figure 6. Top (left): Vale Ferreiro 1 (Bettencourt 2013); top right: Vale Ferreiro 2 (Bettencourt 2013); bottom left: tanged dagger and long tanged dagger or short sword from the Atios necropolis, Budiños; bottom right: copper long tanged dagger or short sword and gold ornaments from Quinta de Água Branca, Vila Nova de Caerveira

(https://www.cm-vncerveira.pt/pages/273).

inside the Cameixa pit, at Boborás, Ourense (Parcero Oubiña 1997; Criado Boado et al. 2000), and the urns deposited in the Boucinhas pits (Bettencourt 2010a). This phenomenon also seems to occur in small cairns located in the highest areas of the coastal reliefs, such as Serra da Muna 1 and 2, at Campo, Viseu (Cruz et al. 1988).

Tombs with more ambitious construction requirements, although underground, began from this period, in areas close to well-irrigated valleys. Such is the case of Vale Ferreiro 1 and 2, at Fafe, Braga (Bettencourt et al. 2005). Cists are also found near watercourses, where bodies were inhumated, revealing a more or less standardised behaviour. One can refer to those cists in which a new 'weapon' was deposited: a long tanged dagger or a short sword, sometimes associated with traditional metallic artefacts or with sumptuous gold artefacts. Examples include the Quinta da Água Branca cist, at Vila Nova de Cerveira, Viana do Castelo (Fortes 1908; Bettencourt 2010a), one of the cists in the Atios necropolis, at Budiños (Vasquez Varela 1980), a cist in the necropolis of Agra da Insula/Pedra Figueira/Pedra Marrada, at Carnota, A Coruña (Vasquez Varela 1980; Bettencourt 2010a), associated with a wrist guard, and the Fariña cist, at Santa Comba, A Coruña (Ruíz-Gálvez Priego 1979) (Figure 6).
In parallel, or already in the transition from the 3rd to the 2nd millennium BCE, burials were made in flat graves, located on sloped areas and overlooking wellirrigated valleys. For example, one of the flat graves in the necropolis in the block of the former Braga post office (CTT), and one of the flat graves of the Pego necropolis - also in Braga (Sampaio 2014). The construction of small cairns is also verified, reoccupying the plateaus of the coastal mountains. This phenomenon already occurred from the third quarter of the 3rd millennium BCE, i.e. Regedoura 2, at Fafe, Braga (Pereira 2018); Illade 3 and Reboredo at As Pontes, A Coruña (Vaquero Lastres 1995); Meninas do Crasto 4, Baião, Porto (Jorge et al. 1988), and is distributed from Asturias to central and northern Portugal,$^{13}$ and is evident in the transition from the 3rd to the 2nd millennium BCE. Examples include monuments such as Monte Deva 5, at Gijón, Asturias (Blas Cortina 1985); Outeiro de Gregos 1, at Baião, Porto (Jorge 1980); Serra da Muna 1 and Serra da Muna 2, at Viseu (Cruz et al. 1998); Vale de Chão 1, at Braga (Vilas Boas 2014) (Table 2). Within this dynamic, it is also important to consider the small cairn of Chã do Carvalhal 1, at Baião, Porto, where tanged daggers and Palmela points were deposited (Cruz 1992), and at the Senhor dos Aflitos, Arouca, Aveiro, where a large cist

\footnotetext{
${ }_{13}$ The phenomenon occurred on a broader geographic basis, also expanding to the south, beyond the area analysed in this work.
} 
Table 2. Funerary contexts from the last quarter of the 3rd/beginning of the 2nd millennia BCE in the Atlantic sub-region of Northwest Iberian Peninsula

\begin{tabular}{|l|l|l|l|l|}
\hline Site & Lab. Ref. & $\begin{array}{l}\text { Conv. Rad. } \\
\text { Age (BP) }\end{array}$ & Cal BC (2 sigma & References \\
\hline Meninas do Crasto 4 & Weighted average & $3815 \pm 36$ & $2457-2140$ & Jorge et al. 1988 \\
\hline Vale Ferreiro, tomb 2 & AA89670 & $3894 \pm 44$ & $2479-2274(89.4 \%)^{*}$ & Sampaio 2014 \\
\hline Reboredo I & GrN-19214 & $3820 \pm 70$ & $2460-2042$ & Vaquero Lastres 1995 \\
\hline Illade 3 & GrN-19213 & $3855 \pm 60$ & $2473-2141$ & Vaquero Lastres 1995 \\
\hline Cameixa, pit & UtCN-7276 & $3778 \pm 33$ & $2340-2120$ & Criado et al. 2000 \\
\hline Serra da Muna 1 & GrN-24056 & $3750 \pm 25$ & $2278-2041$ & Cruz et al. 1988 \\
\hline Boucinhas & AA63072 & $3739 \pm 50$ & $2294-1980$ & Bettencourt 2010a \\
\hline Vale Ferreiro, pit 3 & AA89669 & $3674 \pm 44$ & $2150-1938(90.1 \%)$ & Sampaio 2014 \\
\hline Serra da Muna 2 & Weighted average & $3671 \pm 22$ & $2135-2010$ & Cruz et al. 1988 \\
\hline Vale Ferreiro 1 & Ua-19728 & $3635 \pm 50$ & $2140-1885$ & Bettencourt et al. 2003 \\
\hline Outeiro de Gregos 1 & CSIC-772 & $3620 \pm 50$ & $2140-1786$ & Jorge 1980; 1982; Jorge et al. 1988 \\
\hline Monte da Deva 5 & Beta-165947 & $3580 \pm 70$ & $2135-1746$ & Blas Cortina 1885 \\
\hline Quinta de Água Branca & Beta-230330 & $3570 \pm 50$ & $2109-1755$ & Bettencourt 2010a \\
\hline Quarteirão dos CTT & 14S0/0634 & $3570 \pm 40$ & $2030-1867(79.9 \%)$ & Sampaio 2014 \\
\hline Pego, flat grave 5 & AA89664 & $3540 \pm 55$ & $2026-1742(94.5 \%)$ & Sampaio 2014 \\
\hline $\begin{array}{l}\text { Vale de Chão 1 (central } \\
\text { area) }\end{array}$ & AA-89664 & $3538+42$ & $2009-1749$ & Vilas Boas 2014 \\
\hline
\end{tabular}

* This date, obtained from sediments considered to be the result of the disintegration of the wooden cover of this tomb, may be aged. This could have resulted from the dated material, and the monument may be slightly more recent, taking into account the type of ceramic container deposited there and similarities in the exogenous construction elements found between this tomb and pit 3, dated 2150-1938 cal. BC (Sampaio and Bettencourt 2018).

was associated with tall sub-cylindrical and truncated conical ceramic containers (Pereira 2014). The new constructions were located either close to the old megalithic monuments of the 5th/4th millennia BCE, or in entirely new areas, demonstrating an effective reoccupation of grazing lands.

This stage includes individual burials in copper mines, such as those of El Milagro, at Onís, and El Aramo, Riosa, both in Asturias, where remains of between 19 to 26 individuals were collected, respectively, and sometimes associated with mining artefacts (Blas Cortina 1996; 1998; 2003; 2005). Some belong to this period.

\subsubsection{Adoption of halberds in their different contexts}

Another typical phenomenon of this period is the adoption of halberds by the populations of the Atlantic sub-region of the Northwest Iberian Peninsula. Although the halberd chronology may be questionable, its insertion at this period is based on radiocarbon dating available for the halberds in Great Britain, considered to be predecessors of the Irish and Carrapatas-type halberds, the latter typical of the Northwest Iberian Peninsula. According to Needman et al. (2015), halberds in Great Britain date from the third quarter of the 3rd millennium BCE, but were only adopted in Ireland, and on the Atlantic façade of the European continent, in the final quarter of the 3rd millennium BCE, between 2294$1921 \mathrm{BCE}$, the chronological interval in which we also date them in the Northwest Iberian Peninsula.

They appear to be primarily recorded in the westernmost regions of Galicia and North Portugal, where they occur in 29 outcrops (Bettencourt 2021), a very small number compared to more than 1000 with a stylistic grammar typical of Atlantic rock art (Rodríguez-Rellán et al. 2018; Bettencourt et al. 2017a). These motifs mainly appear isolated or associated with daggers of different types (sometimes of large dimensions), and with graphic elements that differ from previous imagery (Figure 7).

In some cases, they have been recorded on outcrops with Classic Atlantic rock art motifs, probably as agents of appropriation and construction of known landscapes (Bradley et al. 1994), or as agents of reinterpretation or symbolic integration of previously significant spaces, in a new ideological order (Bettencourt 2013; 2017a). It is in this context that we find the first physical armed stelae, or engraved/painted stelae, on more or less abrupt surfaces or horizontal walls. A possible stele from this period, or reused during this period, may be the one from Boulhosa, at Paredes de Coura, Viana do Castelo, which appears to have been recorded with a kind of dagger (Bueno Ramírez et al. 2005). Other paintings and engraved examples include Peña $\mathrm{Tu}$, 

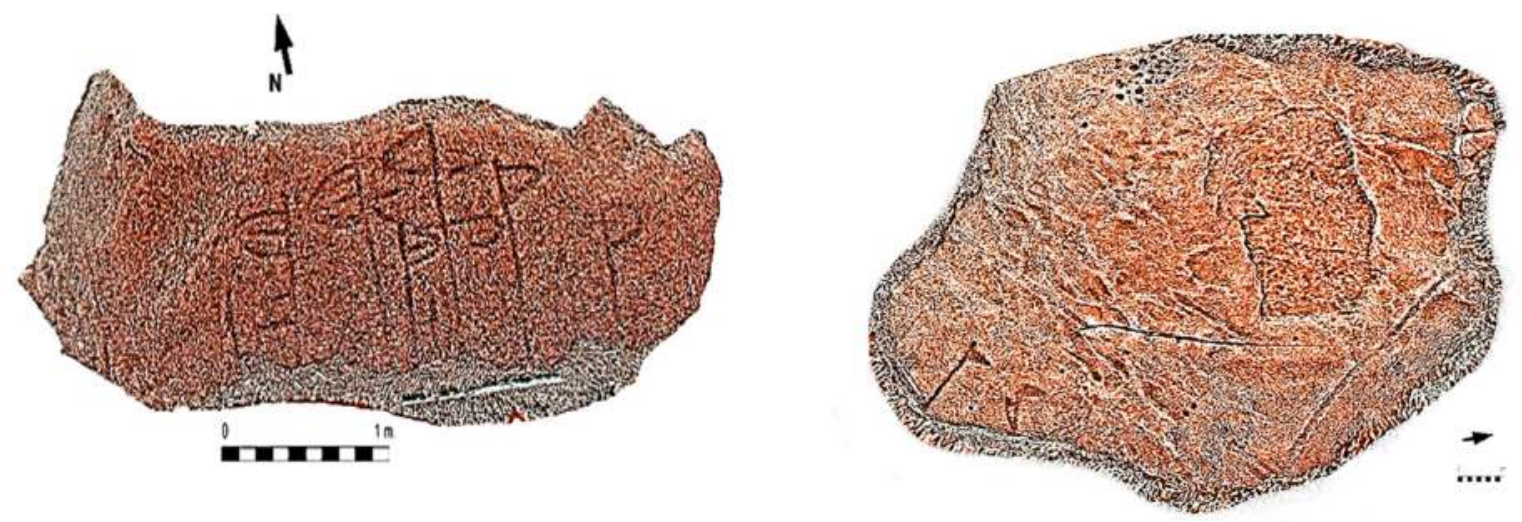

Figure 7. Photogrammetric survey of some engraved halberds. Left: Auga de Laxe 4, Gondomar; right: Costa da Areira 2 , Valença, Portugal (Santos-Estévez et al. 2017).

Vidiago and Llanes, Asturias, a long dagger associated with an idoliform figure (Bueno Ramírez and FernándezMiranda 1981), the idoliform figure of Outeiro do Corno, Teo, A Coruña, also with the representation of a dagger (Fábregas Valcarce et al. 2004) (Figure 8), and from Castriño do Conxo (Peña Santos 1979), which BuenoRamírez (2005: 589) considers as a panel-stele, by the inclination of the engraved outcrop and the similarity between the trapezoidal motif found there and the human face represented on the Longroiva stele. ${ }^{14}$

There are also the first deposits of metallic artefacts, composed of halberds and other copper-based metallic objects. Examples include Monte Lioira, from Leiro, Rianxo, found in the Galician coastal area and in close proximity to the Foxa Vella weapons engravings (Calo Lourido and González Reboredo 1980; Meijidde Cameselle 1989; Comendador Rey 1998), composed of daggers and halberds (Alves and Comendador Rey 2009), as well as the Sarreaus, Ourense deposit (Comendador Rey 1996) found inside a ceramic container and composed of halberds and rivets and long tanged daggers.

\subsection{Mediterranean sub-region}

Data for this sub region are less abundant than for the Atlantic sub-region, but are nonetheless significant. Several settlements, walled enclosures, two funerary contexts, rock engravings, a stele, and deposits of metallic artefacts have been identified. The Castro de Santiago and Fraga da Pena enclosures, at Forno de Algodres, Guarda, were considered here, due to their geographical proximity, and because they are corridors running south-north, easily accessible from the Douro basin.

\footnotetext{
14 This phenomenon is also found in Cantabria, as shown by the 'armed' stele/orthostat of Collado de Sejos, Cantabria (Bueno Ramírez 1983; Teira Mayolini and Ontañón Peredo 2000).
}

\subsubsection{Settlements}

The settlements to be taken into account are: Cemitério de Mouros II, in Mirandela, located on an elevation overlooking the Tua river (Figueiral and Sanches 19981999; 2003); Quinta de Crestelos, in Mogadouro (MartínSeijo et al. 2017a); and the Terraço das Laranjeiras, at Torre de Moncorvo (Gaspar et al. 2014b), located on low and well-irrigated platforms, near watercourses and implanted in areas suitable for farming (MartínSeijo et al. 2017a) (Figure 9, Table 3). There is also the site of Fumo, at Vila Nova de Foz Côa, located in a small, irrigated and low-lying zone that has a natural spring and is protected by outcrops, at the northern end of the Almendra plateau, overlooking Ribeirinha, a tributary of the Côa river (Carvalho 2004).

With the exception of the Cemitério de Mouros II, whose upper platform was circumscribed by a dry stone wall, the others are apparently open settlements, built from perishable materials, where wood (large trunks and branches), in combination with clay, seems to have been the preferred materials. Post-holes, pits, pit hearths, hearths, sunken hut floors, small ditches, and cladding clay are common.

For the settlements where records of pottery assemblages have been published, such as the Cemitério de Mouros II and Fumo, pottery shapes and decorations from the Chalcolithic tradition have been detected, alongside other innovative forms and decorations. In Fumo there are semi-spherical and globular shapes, with a convex base, sometimes with combed or spined decorations, and with filled triangles, simultaneously with shapes of straight walls and inverted truncatedconical vessels, associated with flat-bottom bases and plastic decorations based on cords and nipple-like shapes, as well as rare Cogeces-type pottery (Carvalho 2004). In the Cemitério de Mouros II, decorative motifs and Chalcolithic-style shapes also persist, along with 

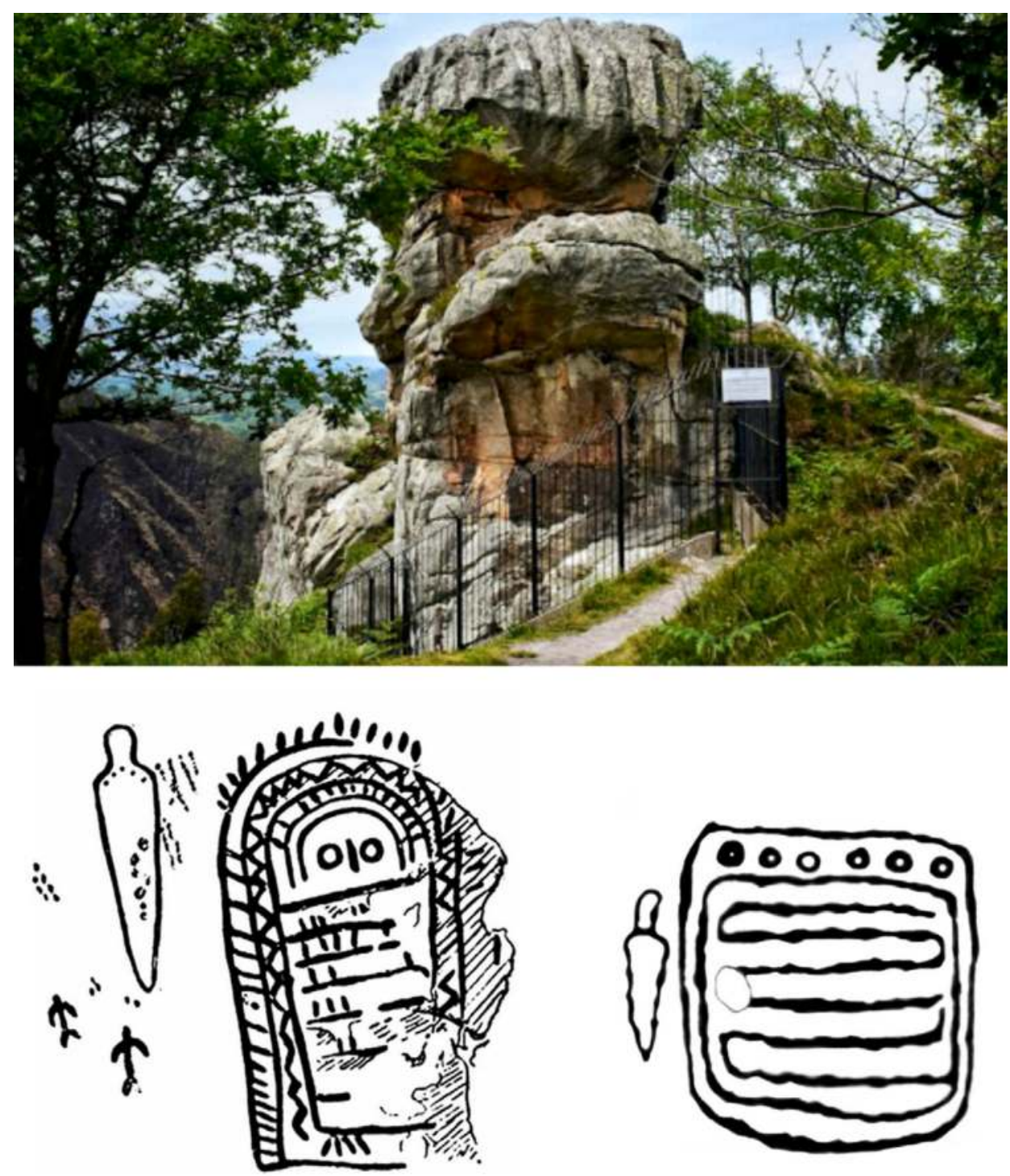

Figure 8. Top: the painted rock shelter in Peña Tu, Vidiago, Llanes, in Asturias (http://www. diariodeloriente.es/2017/10/31/asturias-protege-entorno-del-idolo-pena/); bottom left: long dagger and idoliform of Peña Tu (http://apuntes.santanderlasalle.es/arte/prehistoria/neolitico/pena_tu.htm);

bottom right: idoliform figure of Outeiro do Corno, Teo, A Coruña (Fábregas Valcarce et al. 2004, adapted).

rare, nipple-like shapes and essentially non-decorated pottery (Sanches 1997).

At Fumo and Cemitério de Mouros there are also many flaked stone artefacts, although mostly made of local raw material, such as quartz (Fumo) or mainly quartzite (Cemitério de Mouros). Flint artefacts are rare in both cases. In Cemitério de Mouros the stone artefacts are rudimentary and there are many quern-stones and hand mills (Sanches 1997).

In terms of the activities carried out by the inhabitants living at these sites, indications of degradation of the forest cover have been detected, based on plant macrorests collected in the Cemitério de Mouros II, in the Terraço das Laranjeiras, and in Quinta de Crestelos.
The forest cover was replaced by an increased number of shrub species, e.g. Cistus sp. and Erica), suggesting human activities, probably crop fields around these sites (Figueiral and Sanches 1998-1999; Martin Seijo et al. 2017a). These agricultural activities have been well documented through the discovery of quern-stones and crops at Cemitério dos Mouros II and Terraço das Laranjeiras (Sanches 1997; Martin Seijo et al. 2017a). Zooarchaeological analysis has also made it possible to detect animal husbandry and, indirectly, the existence of pastureland. This is very evident for Fumo, where domestic livestock have been identified, such as sheep and/or goats (Ovis aries/Capra hircus) and domestic ox (Bos taurus), associated with hunting activities, also indicated by the presence of wild species, such as 


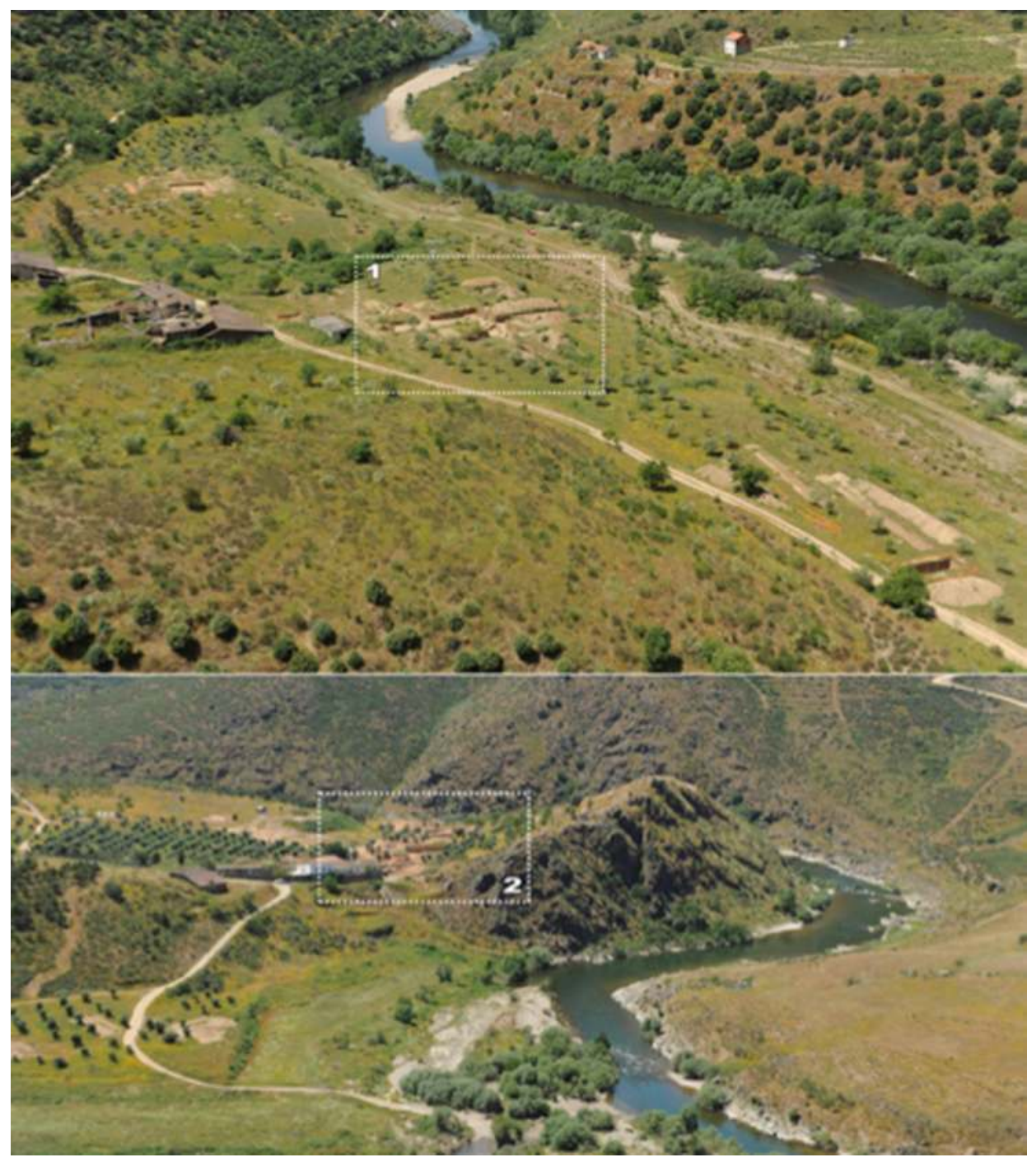

Figure 9. Location of the settlements of Terraço das Laranjeiras (top) and EAB of Quinta de Crestelos (bottom), according to Martín Seijo et al. (2017a, adapted).

Table 3. C14 radiocarbon dating of settlements of the last quarter of the 3rd millennium BCE, in the Mediterranean sub-region of the Northwest Iberian Peninsula

\begin{tabular}{|l|l|l|l|l|}
\hline Site & Lab. Ref. & Conv. Rad. Age (BP) & Cal BC (2 sigma) & References \\
\hline Cemitério de Mouros II & ICEN 788 & $3710 \pm 80$ & $2346-1889$ & Figueiral and Sanches 1998-1999 \\
\hline Fumo & $\begin{array}{l}\text { GifA-99076 } \\
\text { GifA-99077 }\end{array}$ & $\begin{array}{l}3580 \pm 70 \\
3560 \pm 70\end{array}$ & $\begin{array}{l}2135-1743 \\
2129-1693\end{array}$ & Carvalho 2004 \\
\hline $\begin{array}{l}\text { Quinta de Crestelos } \\
\text { (Phase IIa) }\end{array}$ & Beta-398029 & $3600 \pm 30$ & $2031-1888$ & Martín Seijo et al. 2017a \\
\hline $\begin{array}{l}\text { Terraço das Laranjeiras } \\
\text { (Phase B1) }\end{array}$ & Beta-398025 & $3580 \pm 30$ & $2028-1878$ & Martín Seijo et al. 2017a \\
\hline
\end{tabular}


Suidae species (Sus scrofa), red deer (Cervus elaphus), and rabbit (Oryctolagus cuniculus) (Valente 2004).

\subsubsection{Enclosures}

In this sub-region, walled enclosures were important devices for negotiating power during the first half of the 3rd millennium BCE, and therefore it is important to understand subsequent events (Table 4). Whereas Crasto de Palheiros seems to have disappeared in the third quarter of the $3 \mathrm{rd}$ millennium BCE, between 24002300 BCE (Sanches 2008), the settlements located more to the southeast have different dynamics.

At Castelo Velho de Freixo de Numão, in Vila Nova de Foz Côa, Guarda, located on a high spur and with broad panoramic views over the surroundings, Lopes (2019: 380-381) argues that there are no 'secure chronological data that makes it possible to construct the internal stages of the monument during this period, nor, above all, data that indicate the precise moment when the scenography that began in the 1st half of the 3rd millennium BCE was no longer operational'. She also states that in the transition from the 3rd millennium to the 2nd millennium BCE, the monument at Castelo Velho will have become another place, articulated with new architectural constraints and certainly serving new 'social functions', i.e. later than at Crasto de Palheiros.

An observation of the radiocarbon dating of this site, taking into account only those results with the lowest standard deviation, enables a first stage to be established between 2885-2473 BCE, followed by another, between 2471-2293 BCE, and a third, between 2135-1925 BCE, i.e. moments that do not recover, giving the feeling that the place was being reoccupied or used at different intervals, during the second half of the $3 \mathrm{rd}$ millennium BCE, which culminated in the physical and symbolic reordering of the place in the transition from the 3 rd to the 2nd millennium BCE.

It was during this last phase that there were structural reconstructions of the intermediate platform and the two embankments, and structures were built from perishable materials, wood and clay, and featured ditches and fireplaces; an intentionally carinated vessel was deposited. The site was only abandoned in the third quarter of the 2nd millennium BCE. Lopes (2019: 384ff) notes the virtual absence of metallic artefacts during this generic period, changes in the pottery and stone assemblages, as well as in the raw materials used in the latter, which were almost entirely locally sourced. If, on the one hand, there is a persistence of traditional pottery shapes and decorations, with a Chalcolithic background, on the other, there are containers with conical trunks, sub-cylindrical, carinated and sharp neck profiles, often with decorations based on cords and medallions, as well as Cogeces-type pottery (Pereira 1999; Varela 2000; Baptista 2003).

The walled enclosure at Castanheiro de Vento, in also Vila Nova de Foz Côa, Guarda, located on a hill offering a $360^{\circ}$ panoramic view, presents several problems related to the objective of this paper, because the majority of excavations have not found evidence of the stratigraphic and constructive sequences of the enclosure, although this interpretation has recently changed (Muralha et al. 2018; 2019). In recent works, two levels have been identified: one prior to the construction of the outer wall of the enclosure, whose artefactual component

Table 4. C14 radiocarbon dating of enclosures by the last quarter of the 3rd millennium BCE, in the Mediterranean sub-region of the Northwest Iberian Peninsula

\begin{tabular}{|l|l|l|l|l|}
\hline Site & Lab. Ref. & $\begin{array}{l}\text { Conv. Rad. } \\
\text { Age (BP) }\end{array}$ & Cal BC (2 sigma) & References \\
\hline $\begin{array}{l}\text { Castelo Velho de Freixo de } \\
\text { Numão }\end{array}$ & CSIC-1813 & $3793 \pm 34$ & $2344-2132$ (94.1\%) & Jorge, S. 2003 \\
\hline $\begin{array}{l}\text { Castelo Velho de Freixo de } \\
\text { Numão }\end{array}$ & CSIC-1333 & $3650 \pm 28$ & $2135-1925$ & Jorge, S. and Rubinos 2002 \\
\hline Fraga da Pena & Sac-1543 & $3710 \pm 60$ & $2287-1925$ & Valera 2007 \\
\hline Castanheiro do Vento & Ua-23428 & $3740 \pm 40$ & $2234-2029(87.9 \%)$ & $\begin{array}{l}\text { Jorge, V. et al. 2003; Cardoso } \\
\text { 2007 }\end{array}$ \\
\hline Castanheiro do Vento & Ua-33632 & $3725 \pm 30$ & $2203-2032$ & $\begin{array}{l}\text { Jorge, V. et al. 2003; Cardoso } \\
\text { 2007 }\end{array}$ \\
\hline Castanheiro do Vento & Ua-23430 & $3720 \pm 40$ & $2210-2016$ (91.4\%) & $\begin{array}{l}\text { Jorge, V. et al. 2003; Cardoso } \\
\text { 2007 }\end{array}$ \\
\hline Castanheiro do Vento & Ua-32087 & $3630 \pm 45$ & $2135-1890$ & $\begin{array}{l}\text { Jorge, V. et al. 2003; Cardoso } \\
\text { 2007 }\end{array}$ \\
\hline Castanheiro do Vento & Sac-2018 & $3580 \pm 80$ & $2142-1737$ (93.6\%) & $\begin{array}{l}\text { Jorge, V. et al. 2003; Cardoso } \\
\text { 2007 }\end{array}$ \\
\hline
\end{tabular}

* Layer 3 radiocarbon dating, with smaller standard deviations. 
Table 5. C14 radiocarbon dating for funerary and depositional contexts for the interior sub-region of the Northwest Iberian Peninsula

\begin{tabular}{|l|l|l|l|l|}
\hline Site & Lab. Ref. & Conv. Rad. Age (BP) & BC (2 sigma) & References \\
\hline $\begin{array}{l}\text { Lorga de Dine (human } \\
\text { bones) }\end{array}$ & $17 \mathrm{~T} / 0450$ & $3630 \pm 40$ & $2134-1892$ & Pereira et al. 2018 \\
\hline $\begin{array}{l}\text { Lorga de Dine (human } \\
\text { bones) }\end{array}$ & $17 \mathrm{~T} / 0449$ & $3610 \pm 40$ & $2131-1881$ & Pereira et al. 2018 \\
\hline $\begin{array}{l}\text { Terraço das Laranjeiras } \\
\text { (cist) }\end{array}$ & GrA - 54501 & $3615 \pm 35$ & $2042-1888(90.4 \%)$ & Gaspar et al. 2014a \\
\hline $\begin{array}{l}\text { El Pedroso/Casa del } \\
\text { Moro (cave) }\end{array}$ & WK13796 & $3798 \pm 53$ & $\begin{array}{l}2458-2416(4.8 \%) \\
2410-2127(85.3 \%) \\
2089-2046(5.4 \%)\end{array}$ & Bradley et al. 2005 \\
\hline $\begin{array}{l}\text { El Pedroso/ Casa del } \\
\text { Moro (cave) }\end{array}$ & WK13797 & $3736 \pm 44$ & $2286-2024(95.4 \%)$ & Bradley et al. 2005 \\
\hline
\end{tabular}

belongs to the late 4th/early 3rd millennia BCE, and another, established by radiocarbon dating, between 2700 and $1700 \mathrm{BCE}$, too broad a time period for the resolution of the questions raised in the framework of this paper.

In this same area, the occurrence of a short tanged dagger with side lateral cut-outs (a mixed form that combines Mediterranean and Atlantic traditions) appears to be associated with the base of a stony structure that seems to restructure the space delimited by the outer wall of the enclosure, in a recurrence of a permanent construction process that Cardoso (2007) and Vale (2011) recognise as being characteristic of the Chalcolithic period. Considering that the typology of this dagger refers to the third or fourth quarter of the 3rd millennium $B C E$, such a process would still be active in the second half of the 3rd millennium BCE. During the 2nd millennium BCE, the most disruptive factor found at Castanheiro do Vento is the occurrence of Cogeces-type pottery fragments; however the stratigraphic context in which they occur has not been sufficiently excavated to enable an outline of the nature of the associated social activities. Whatever the content of the actions or frequency of use that occurred in the most recent phases of this enclosure, after the last quarter of the 3rd millennium BCE it was no longer active, according to the set of radiocarbon dates published by Jorge, V. et al. (2003) and Cardoso (2007), especially considering those with the lowest standard deviation.

On the border between Castile (Spain) and Northeast Portugal, the monumentalised top of El Pedroso's enclosure, Zamora, does not appear to have continuity for subsequent periods (Delibes de Castro et al. 1995)

Further south, in Central-North Portugal, the walled enclosure of Castro de Santiago, at Fornos de Algodres, seems to have been abandoned, perhaps in the first half of the 3rd millennium BCE (Valera 2007: 100). The walled enclosure of Fraga da Pena, also at Fornos de
Algodres, and located in a natural circulation corridor leading to the Douro/Muxagata stream, was only built at the end of the 3rd millennium BCE. Semi-spherical containers of Chalcolithic tradition, maritime and 'local' Bell Beakers vessels, and shaped forms associated with innovative decorations conveyed with the Meseta Norte (conical trunk, carinated, S-shaped or subcylindrical profiles, some decorated with strings and cords and associated with flat bases), were deposited, showing, as Valera (2000: 600) argues, a phenomenon of 'compatibilisation between a tradition locally rooted throughout the millennium and the arrival of external influences... which suggest that this local space began to be integrated, in a less autarchic manner, within a dynamic that transcends it'.

\subsubsection{Funerary contexts}

The funerary contexts for this period ${ }^{15}$ are rare (Table 5), although inhumation practices predominate. Remains of a child were found inside a cist at Terraço das Laranjeiras (Gaspar et al. 2014), and two adults in the Lorga de Dine cavity, at Vinhais, Bragança (Pereira et al. 2018). The burial at Terraço das Laranjeiras seems to have been primary (Gaspar et al. 2014), and at Lorga de Dine (Harpsoe and Ramos 1985; Pereira et al. 2018), but there are not enough data to clarify what type of deposition occurred, given the age of the excavations conducted there, the turning of the osteological materials, and the lack of any systematic study of the human remains. In the case of Terraço das Laranjeiras, the burial took place within the settlement.

It is likely that the cists of Lagares, at Macedo de Cavaleiros, Bragança, that are more than $1 \mathrm{~m}$ long (Alves 1975), indicate a primary inhumation practice, and, being located in an irrigated valley, can be considered

\footnotetext{
${ }_{15}$ The findings of the sub-basin of the Tâmega river, in western Trásos-Montes, were not counted, because in geographic terms they occurred in an area of Atlantic influence.
} 

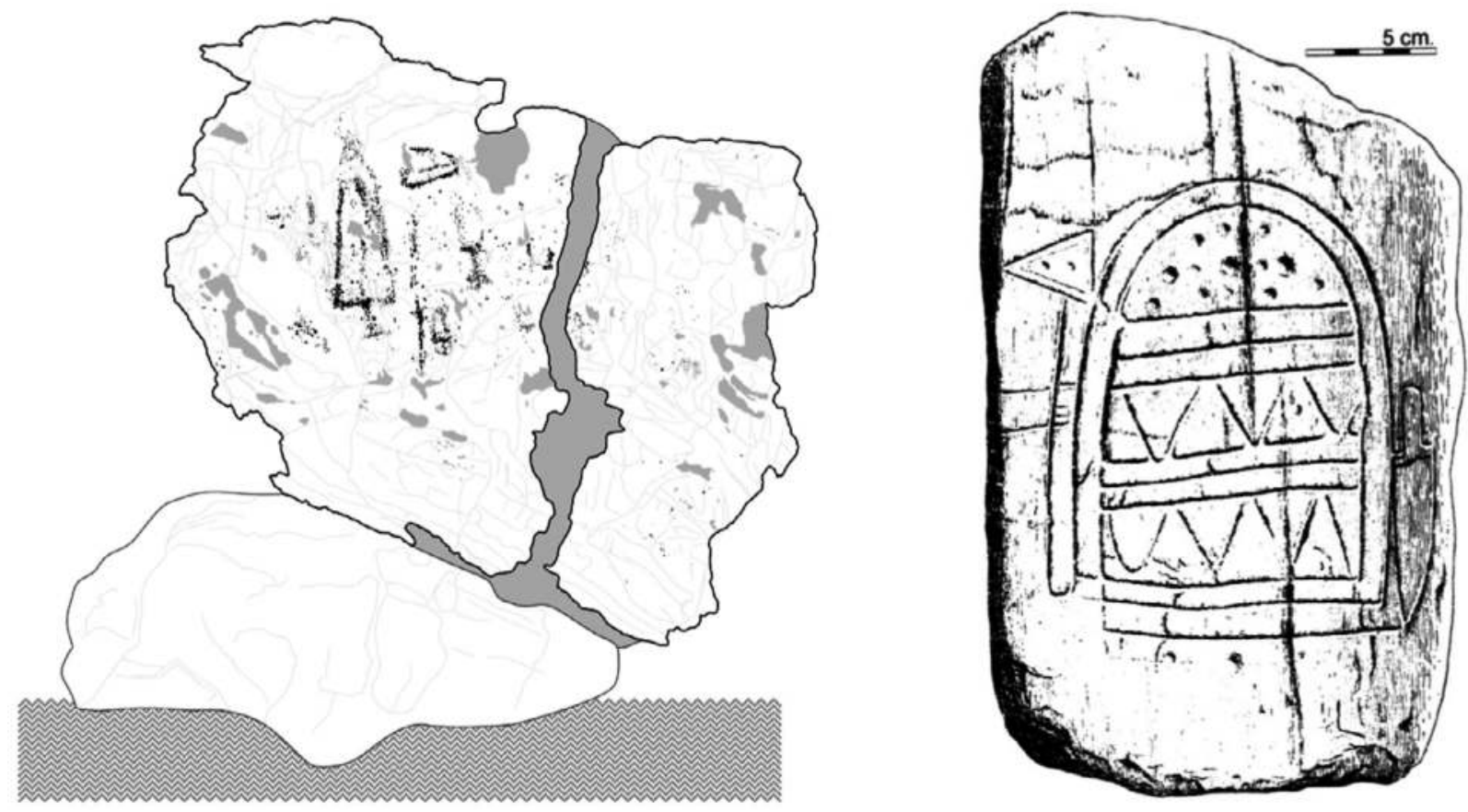

Figure 10. Tracing from Vale de Figueira 11, Torre de Moncorvo (Silva et al. 2017), and the stele of Tabuyo del Monte, Léon (Almagro Basch 1972).

from this generic period due to the associated articles found in the graves (Bettencourt 2010a).

\subsubsection{Recorded contexts}

A granitic shelter with engraved Schematic art (anthropomorphic and reticulated figures), located on a slope of the walled enclosure of El Pedroso, probably dates from the last quarter of the 3rd millennium BCE. Evidence was found of deposition of a Palmela point, carbonised acorns, barbed and tanged flint arrowheads, and several fragment of copper. The dates of this cavity reveal an occupation gap in relation to the end of the use of a stone structure, built on an artificial platform in front of it (2680-2458 BCE). The archaeologists responsible for the dig admit, however, that the large number of artefacts found 'in the disturbed levels overlying this structure [suggest] that activity on the terrace may have continued for some time after the platform had gone out of use' (Bradley et al. 2005: 132, 134). At these disturbed levels, the sherds of maritime and linear Bell Beaker pottery, Cogece-type, and flat-bottomed pottery containers that increased significantly in the upper levels', may be related to the subsequent occupation of the shelter.

There are also three outcrops engraved with Carrapatastype halberds: at Pedra Escrita de Ridevides 1 and $2{ }^{16}$ Alfandega da Fé (Santos Júnior 1963; Bettencourt 2021; Abreu 2012, Vol. IV: 110), and at Vale Figueira 11, Torre de Moncorvo, in association with two types of daggers, one of them long (Figueiredo 2013; Silva et al. 2017) (Figure 10). The former are flattened surfaces, located in the Vilariça valley, whereas the latter is a vertical outcrop near the Figueira stream, and almost resembles a stele, i.e. designed to be seen from the front. It is also worth mentioning the halberd engraved on the slab, used as a door slab in a house in Vale do Juncal, in the parish of Abambres, Mirandela (Sanches 1994), a low altitude site near the left bank of the Tuela. The Longroiva stele, at Cruzeiro Velho, Lugar de Quintãs, in Mêda (Guarda), also dates from this period, in an area rich in mineral-medicinal waters in the Longroiva tectonic depression, a natural north-south corridor. ${ }^{17}$ In this engraving, the male character carries a halberd, a long tanged dagger/or short sword, as well as a bow and arrow (Jorge and Jorge 1990).

Although this figurative grammar is not very common in the interior zones, there is a stele at Tabuyo del Monte, in Léon, Spain (Almagro Basch 1972), in the Valtabuyo river valley, where a halberd and a long tanged dagger are associated with an idoliform motif, similar to those found on the Atlantic façade. This suggests that the Douro basin was an important route of penetration from the coast to the interior.

${ }^{16}$ The name means 'the Written Stone of Ridevides'. 


\subsubsection{Other contexts}

In the Mediterranean sub-region, there are also several deposits of Carrapatas-type halberds. ${ }^{18}$ Examples include those at Valebenfeito and Carrapatas, both in Macedo de Cavaleiros (Bartholo 1959), at Monte dos Mouros/Abreiro, Mirandela (Bartholo 1959), Alto das Pereiras, Vimioso (Bartholo 1959), El Arribanzo de Fariza, and Sayago, Zamora, near the bank of the Douro, on the Portuguese/Spanish border (López Plaza and Santos 1984-1985). ${ }^{19}$ The unmistakable association of these findings as hoards is suggested to us, for example, by the location of Abreiro, in the section between Abreiro and Quinta da Pendurada, hidden in the fissure of a rock, at the base of the south-eastern slope of the settlement of Cemitério dos Mouros, very close to a stream and discovered when a road was being built (Bartholo 1959; Sanches 1995).

\section{Data discussion and interpretations. What kind of 'turning point' occurred between the 3rd and 2nd millennia BCE?}

Since the data have been treated differently between the two biogeographic sub-regions under analysis, it is important to discuss the two regions in an identical manner.

Thus, in response to the central question posed by this work, and on the basis of the available data, the Atlantic sub-region, in the final quarter of the $3 \mathrm{rd}$ millennium BCE, appears to have undergone a period of profound and structural change, at a social and ideological level, materialised in countless day-today contexts. This hypothesis has already been put forward for North Portugal (Bettencourt 2009; 2010a; 2013). This is demonstrated by the abandonment of Chalcolithic settlements, which occurred almost systematically in Portugal $^{20}$ and Galicia, ${ }^{21}$ and the

\footnotetext{
18 Designation attributed by Schubart (1973).

19 The closest archaeological context is a settlement with incised decoration shaped like an ear of cereal, and Boquique-type pottery attributed by Plaza and Santos (1984-1985) to the Early Bronze Age.

${ }^{20}$ We refer to the Chalcolithic settlements of Bitarados, Esposende (Bettencourt et al. 2007a; Bettencourt et al. 2007b; Cardoso and Bettencourt 2008), Covelinhos, Braga (Bettencourt et al. 2007b), Quinta do Assento, Guimarães (unpublished), and Pastoria and Vinha da Soutilha, Chaves, to the Tâmega basin (Jorge 1986). The first two were abandoned c. 2500-2400 BCE, based on the C14 radiocarbon dating that has been published (Lopes and Bettencourt 2017).

21 For Galicia, without offering an exhaustive list, this situation applies to the settlements of Requeán, at Toques, A Coruña, which probably ended between 2821-2631 BCE (at 68.5\%), according to the radiocarbon dating of CSIC-898: 4200 \pm 50 BP (González Méndez 1992; 2000), of Lavapés, at Cangas, Pontevedra, which probably ended between $2620-2461 \mathrm{BCE}$ at (95.4\%), according to the radiocarbon dating of CSIC-1532: 4000 \pm 36 (Gómez Fernandez et al. 2001; 2004), and Monte de Remédios, at Moaña, Morrazo, Pontevedra. This list only considers settlements with greater stratigraphic power, or which have been published in greater detail. In the case of Monte de Remédios, the level of pottery with pot shapes, S-profiles, flatbottom bases and decorations, with applied cords or nipple-like
}

emergence of innovative settlement strategies. The new settlements were linked to the bottom of fertile valleys (e.g. Boucinha and Rossio), in the Atlantic subregion, and were also associated with irrigated and fertile soils (e.g. Setepías), in mid-altitude spurs which offered easy access to watercourses and the sea (e.g. Os Torradoiros), as well as in sheltered areas, with low water accumulation, but in mountainous zones (e.g. Poza da Lagoa/Viveiro 2 and A Lagoa P.A. 45.04). Specialised settlements are still to be considered for certain activities, such as La Campa les Mines, linked to the exploration and transformation of copper ore, or the camp at Carreço-Praia, where only macrolithic artefacts were found, thought to be associated with the exploration of sea salt, based on the evaporation of sea water in removable shale sinks (Figure 11). This diversity of sites allows us to hypothesise the existence of a networked settlement, where some sites, of greater longevity, were perhaps connected with others of a more seasonal and perhaps cyclical nature, both for pastoral and mining activities, in a new structuring of the landscape that was consolidated in the first half of the 2nd millennium BCE. This seems more similar to the Cantabrian Chalcolithic period (Ontañón Peredo 2003) and deviates from the model proposed by Méndez (1994; 1998), based only on places of height, of cyclic frequency, designated as areas of accumulation and associated with a transhumance-type way of life. These accumulation areas would correspond to just one more territory to be explored in the context of a more global phenomenon of territorialisation, exploitation, and 'conquest' of various resources. It should be noted that the settlements that existed in the first quarter of the 2nd millennium BCE follow the same complementary settlement strategies. Examples include Lamas de Abade and Monte Calvo in mid-to-high altitude zones, and A Pataqueira, Monte de Cabanas, Sola IIa and Fraga do Zorro, connected with valleys and Areias Altas, on the coastal platform, linked to the exploration of salt and other marine resources.

On the basis of the obtained data, the same hypothesis of discontinuity can be applied to the walls and ditches enclosures of the Chalcolithic period. There was a sterile deposit, of about $20 \mathrm{~cm}$, between Sola I (CA) and Sola IIa (EBA) (Bettencourt 2000), in areas where the stratigraphy has been best preserved. For Castelo de Chás, linked to the Tâmega sub-basin, there are no known pottery assemblages considered to date from the Bronze Age. In the Montenegro enclosure, a sloped

\footnotetext{
shapes, certainly from the Bronze Age, is not based on radiocarbon dating, and therefore it is not possible to state that there is continuity of occupation with the Chalcolithic period, as highlighted by those responsible for the excavations (Fábrega Valcarce et al. 2007). It is therefore strange that Gónzález Blanco and Lilios (2018) claim that the site was intermittently occupied between c. 4500-1800 BCE to justify that some settlements that existed in the Chalcolithic period continued to be active in the Early Bronze Age.
} 
area was excavated and Bronze Age pottery found, but its connection with the Chalcolithic areas of the enclosure is dubious, and its precise chronology in the context of this period is unknown. The same can be said for the ditch enclosure at Forca. ${ }^{22}$

The identity-based artefacts of day-to-day life disappear, seemingly abruptly - such as the 'decorative' baroque pottery known as incised/impressed Penhatype pottery, frequently associated with globular or semi-spherical shapes, ${ }^{23}$ replaced by closed forms, often in S-shaped profile, with flat bases and decorations, based on cords and nipple-like shapes under the rim, in the new settlements. There is also evidence that the communities felt the need symbolically to appropriate several significant spaces used by their ancestors, such as places traditionally engraved with Classical Atlantic rock art, alongside the affirmation and possession of new sites, through the recording of innovative and figurative symbols - such as halberds and daggers (Bettencourt 2013; 2017a; 2017b), thereby creating a first 'armed landscape' that gradually asserted itself in the western façade of the Northwest Iberian Peninsula, reflecting the introduction of new 'narratives' and new myths and the adoption of a new ideology that broke with old traditions and ancestral representations of the world, which dated back from the Neolithic and the Chalcolithic periods, and consolidated new identitybased phenomena (Peña Santos 2001: 258; Bettencourt 2013; 2017a; 2017b) that are intended to be fixed in space and recalled in the future. This indicates new symbols of power and new ceremonies, probably of a religious-magical nature, where new metal artefacts were physically or mentally manipulated, regardless of whether they were perpetrated, or presided over, by groups of warriors, 'priests', warriors/priests, princes, or beings with exceptional properties. This way it is possible to advance the hypothesis that places that were engraved with halberds and daggers, marked new structured places, from the end of the $3 \mathrm{rd} /$ beginning of the 2nd millennia BCE, around which a wide network of interconnected places was structured.

\footnotetext{
22 Although it has been previously argued that this enclosure could have persisted in the Early Bronze Age (Bettencourt 2009; 2010b; 2013), based on a few ceramic sherds from a stratigraphic level that cuts across a ditch built in the Chalcolithic period, it is not possible to establish continuity of occupation because this level has not been dated.

${ }^{23}$ The most recent dates for contexts of this type are probably between 2500-2400 BCE, which is taken from dates AA63065: 4046 \pm 42 BP (2680-2470, 86.8\% at 2 sigma) for the settlement of Bitarados (Bettencourt et al. 2007b); from date AA63063: 3969 63 BP (2574-2436, $55.5 \%$ at 1 sigma and $2637-2286,93.2 \%$ at 2 sigma) for the settlement of Covelinhos (Lopes and Bettencourt 2017); and the dates Beta258088: $3980 \pm 50$ BP (2576-2460 at 1 sigma and $2625-2337,94.5 \%$ at 2 sigma) for a context with pottery of this type in the ditch enclosure of Forca (Bettencourt 2010b). However the date A6/318: 4327 \pm 93 by B-OSL (2414-2228 BC) of the base of one ditch at Forca (Valera and Rebuge 2008) may indicate a slightly more recent dating.
}

The appearance, even though incipient, of physical or engraved or painted armed stelae, seems to indicate the representation of the symbolic or real importance of characters that were socially differentiated from the community, because they had a set of weapons that gave them distinctive properties and powers. ${ }^{24}$ This indicates the emergence of societies that needed to assert themselves or give visibility to personalities with specific attributes, as well as places where they were venerated.

The phenomenon of deposition of metallic, copperbased artefacts, in areas that were not linked to enclosures, also became more common in this period, including Carrapatas-type halberds and various types of daggers. Although they are not in large numbers, they are significant because they reveal another way of ritualising exceptional and power-based objects, as well as new ways of celebrating other places in the world. Following this line of reasoning, it is worth asking whether the deposition of flat copper axes in outcrop ridges engraved with Classical Atlantic rock art, at Pedra do Lombo da Costa and Laxe das Coutadas, both in Cotobade, Pontevedra (Sobrino 1935), corresponded to another expression of this logic of mastery over old symbols, or, on the contrary, to a phenomenon of social resistance and 'invisible' continuity of celebration of these traditions.

There is also evidence of affirmation of new icons of power, made of copper or gold, of Atlantic expression, such as long tanged daggers or short swords, and strap gold diadems, bracelets or rings, associated with the funerary world, sometimes, in innovative combinations with more traditional power icons, such as Palmela points, short daggers and wrist guards, that existed in the Northwest Iberian Peninsula in previous periods. These associations are interesting insofar as they inscribe traditional icons in the new symbology that was being implemented.

Although individual burial by inhumation, linked with wet areas, had occurred since 2468-2332 BCE in the Atlantic sub-region, this practice became more evident and diversified in contexts of more or less complex cists, where innovative power icons were deposited, probably representing phenomena of appropriation and legitimation by the new elites, of these territories that had major agricultural potential (Bettencourt 2010a). These elites not only controlled economic activities, but also possessed magical religious knowledge, skills and abilities that enabled them to legitimise the occupation of the territory and assert themselves in a changing world (Bettencourt 2008; 2010a).

\footnotetext{
${ }^{24}$ Ontañón Peredo (2019) defended similar ideas for figurations of this type in Cantabria, in northern Spain.
} 


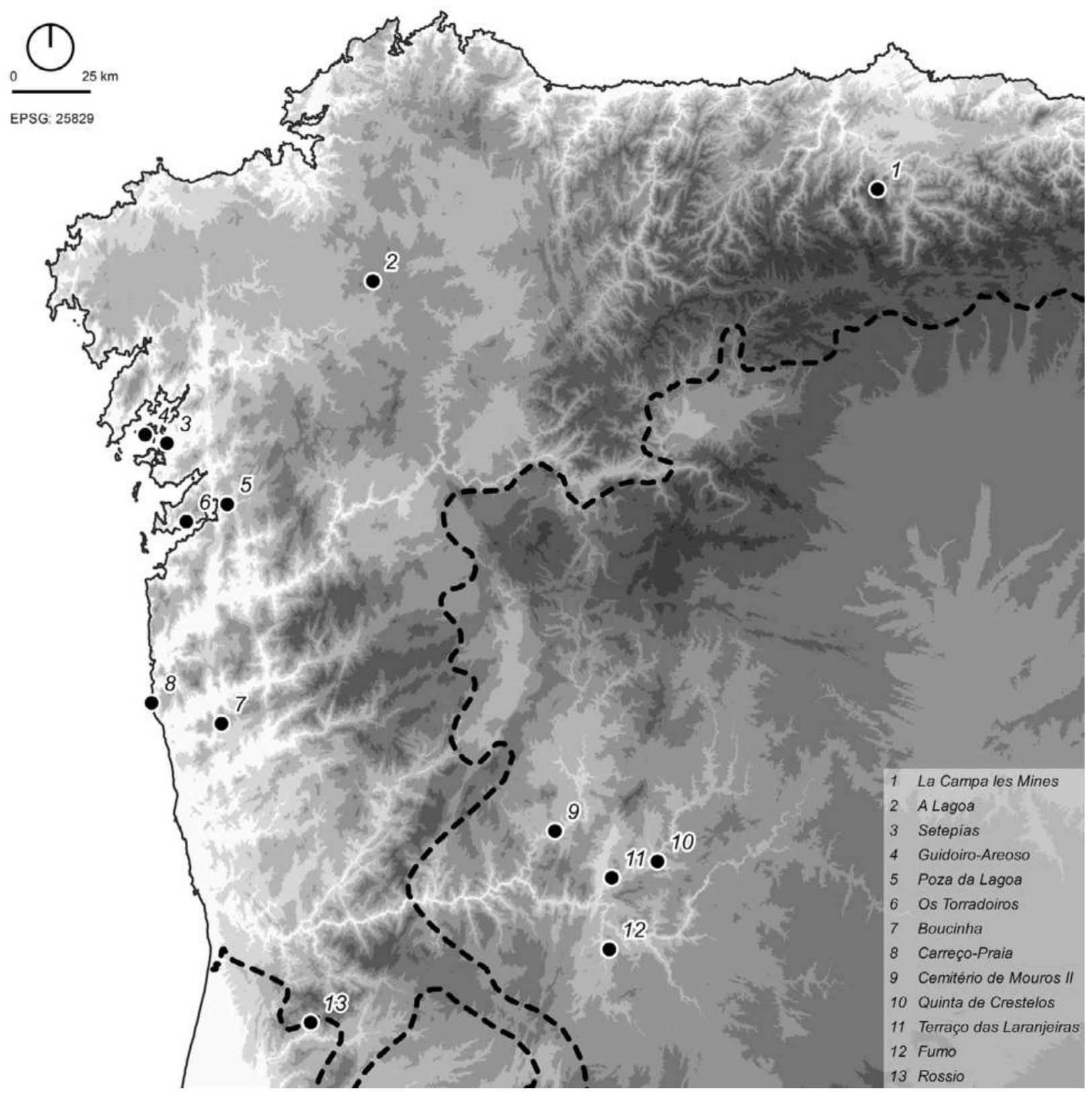

Figure 11. Location of the settlements cited in the text in the different Atlantic and Mediterranean sub-regions of the Northwest Iberian Peninsula.

There is also evidence of burials in flat graves, with depositions of simple ceramic containers, in wellirrigated slopes, overlooking watercourses that probably represent people of a different social status.

Another phenomenon that seems to develop from 24002200 BCE is the re-occupation of mountain plateaus, with small cairns, after a hiatus of more than 500 years, and breaking with the absence of funerary megalithic constructions that seems to have occurred during the first half of the 3rd millennium BCE. This phenomenon accompanies the emergence of new camps or seasonal settlements in the lower slopes of hills, as Fábregas
Valcarce (2010) has already defended for Monte Penide, in Galicia.

Thus, during this period, social and ideological structural changes took place, and the spaces for the negotiation of power and identity were also inverted, compared to the first half of the 3rd millennium BCE. Large community enclosures were replaced by new significant and structured places, such as places engraved with weapons or armed stelae, often near to waterlogged areas, springs, or on well-irrigated platforms, as well as sites where new 'ancestors' were venerated, deposited in unusual burial structures, or with unusual offerings. One example is Vale Ferreiro, 
at Fafe, Braga (Bettencourt et al. 2005; Bettencourt 2008; 2010a; Sampaio and Bettencourt 2018).

In the Mediterranean sub-region of the Northwest Iberian Peninsula there seems to be a dynamic that is different from that found in the Atlantic subregion. There was greater resistance to change, and, as consequence, change occurred more slowly, and perhaps asymmetrically, between the western and eastern zones of this region.

It seems evident that there was an alteration of the Chalcolithic settlement strategies, with abandonment of settlements located in medium-altitude reliefs offering more or less dominant panoramic views over the surrounding valleys ${ }^{25}$ (with the exception of Cemitério de Mouros II), which were replaced by new settlements on fluvial terraces (Quinta das Laranjeiras, Quinta de Crestelos) or areas closer to valleys (Fumo), ${ }^{26}$ articulated with new forms of territorial control (Figure 11). But there are indicators of continuity within this process of change that must also be taken into account. In the new settlements, this includes continuation of the shapes and decorations of the identity-based pottery of the 3rd millennium BCE, alongside other formally and decoratively distinct groups, as well as the permanence of significant production of flaked stone artefacts.

Continuities also occur, for example, in the construction, during this period, of a walled enclosure (Fraga da Pena), considered to be a phenomenon of resistance by Valera (2007), and, perhaps, in the ceremonial enclosure of Castelo Velho de Freixo de Numão, where it seems that the local population started to alter, albeit slowly, the stone structure of the place. However, in other devices of collective power, from the first half of the 3rd millennium BCE, there was constructive divestment or condemnation of such power (e.g. Crasto de Palheiros and Crasto de Santiago). The depositional shelter of Buraco da Pala in Mirandela, Vila Real (Sanches 1997) was also abandoned, indicating that the reorganisation of the traditional system of land

\footnotetext{
25 Examples include the settlements of São Lourenço, at Vila Pouca de Aguiar, Vila Real (Jorge 1986), Pedreira and Regadas, at Alijó, Vila Real (Teixeira 2019) and Cunho and Barrocal Alto, at Mougadoro, Bragança (Sanches 1992; Cardoso 2014). The latter was considered to mark the transition from the 3rd to the 2nd millennia $\mathrm{BCE}$, but after the calibration of $\mathrm{C} 14$ dating it was found that it was occupied from the first half of the $3 \mathrm{rd}$ millennia BCE. It also has some pottery with decorations in the form of an ear of cereal, of Bouquique-type and flat bottoms, linked to Cogeces-type pottery, whose chronology is unknown but which may correspond to the second half of the 2nd millennium BCE, taking into account the date UGRA-223 of 3220 \pm 100 BP (1701-1260, 93.1\%), which Sanches (1992: 107) not valorise, but which is suitable for this type of material.

${ }^{26}$ A phenomenon that continues to be found in subsequent moments, as can be seen by the Middle Bronze Age settlement of Foz do Medal, at Mogadouro, Bragança (Gaspar et al. 2014b), and of Eira, at Vila Nova de Foz Côa, Guarda (Canha et al. 2018), both on river terraces near areas with agricultural potential.
}

occupation was already irreversibly underway at the end of the 3rd millennium BCE, which then led to a new cultural identity phenomenon.

In funerary terms, parameters of comparison with the Chalcolithic period are difficult, given the lack of evidence for this period, although some continuities do seem to have persisted. The tradition of burial in caves continued, of which the Lorga de Dine is a paradigmatic case of continuity between the second half of the 3rd and the beginning of the 2nd millennia $\mathrm{BCE}$, with burials carried out at staggered intervals over this period (Pereira et al. 2018). The same can be said for the tradition of inhumation of corpses in cists in riparian areas, which existed from the Chalcolithic period (Vale da Cerva) to the Early Bronze Age (Terraço das Laranjeiras) (Gaspar et al. 2014a) to indicate the territorial appropriation of fertile valleys (Bettencourt $2009 b ; 2011)$. Contrary to the situation in the Atlantic sub-region, no individual tombs are known emphasising the social status of certain individuals, symbolised by exceptional artefacts (perhaps with the exception of one of the cists in the necropolis of Lagares), which may be related to the lack of research into this period and the lack of radiocarbon dating of some caves with human remains accompanied by daggers, that have been considered to be older.

The phenomenon of halberds recorded in open-air outcrops, of which there are numerous examples in the Atlantic sub-region, does not find much correspondence in the interior zones, at least on the basis of currently available data, which perhaps corresponds to a phenomenon of resistance to the associated ideology. It must be admitted, however, that, at least on a sporadic basis, in areas linked to valleys (Tua, Vilariça, Figueira, ${ }^{27}$ and Longroiva tectonic depressions), similar phenomena to those found in the Atlantic sub-region also occurred, with affirmation of new spaces for the negotiation of power, distinct from those of the Chalcolithic period.

In this sub-region, these new icons of power are fundamentally found in terms of phenomena of hiding/deposition, perhaps in greater conformity with the ancestral habits of depositions in enclosures and cavities, although this practice primarily occurs in valley and land- and river-based corridors (Senna Martínez 2017) - new spaces of special importance in this new era.

Taking into account the set of changes and continuities observed in the Mediterranean sub-region of the Northwest Iberian Peninsula, the phenomenon of change between the Chalcolithic and the Early Bronze Age, essentially verified in the framework of the last

7 A tributary on the right bank of the Sabor. 
quarter of the 3rd millennium BCE, is characterised by social resistance and continuities, and is assumed to be more recent than the situation found in the Atlantic sub-region.

In summary, the Northwest Iberian Peninsula, from the last quarter of the 3rd to the beginning of the 2nd millennia BCE presents itself as a region of biogeographic and cultural asymmetries, guided by different rhythms of change, and, consequently, by phenomena of innovation and resistance, in a mosaic of local contingencies that escape the overly generalising views of some syntheses.

The 'reality' is certainly different from the unifying panorama proposed by Blanco González et al. (2018: 58), where this territory is perceived in the transition from the Chalcolithic to Early Bronze Age as an area of 'relatively minor changes in the realms of settlement and where Neolithic-like ${ }^{28}$ lifestyles endured longer there and cultural shifts occurred later than in other Iberian areas'. On the contrary, the scarcity of settlements in this first stage of the Early Bronze Age, ${ }^{29}$ the tendency for the appearance of ex-nihilo settlements in low or higher areas, the alteration of pottery forms and decorative symbolism, the appearance of new icons of power and new places of negotiation of the same (more expressive on the coast), disinvestment in the construction of monumental architectures of social aggregation, and the disarticulation of the supra-regional exchange networks with the south, in substitution of a greater emphasis on the Atlantic world, seems to be implanted in the last quarter of the 3rd millennium BCE, with all the social, ideological and economic implications that this implies, advocating the changes that were to be consolidated over the 2nd millennium BCE.

Although not so widespread, this proposal had already been defended for the Atlantic sub-region of Northwest Portugal (Bettencourt 2009; 2013). In this sense, the end of the 3rd millennium BCE in the Northwest Iberian Peninsula is a period that seems to be fragmented rather than revealing continuities, initiating a new way of life that seems to start earlier on the Atlantic façade, perhaps between 2400 and $2300 \mathrm{BCE}$, and between about 2200 to $2000 \mathrm{BCE}$ in the interior.

\section{Factors of change}

What are the reasons for these changes? The answer will not be mono-causal since economic, social and ideological change is almost always the result of an

\footnotetext{
${ }_{28}$ The authors consider that a Neolithic way of life is maintained in the Chalcolithic period.

${ }_{29}$ A fact that can also be related to either erosive phenomena in high altitude areas or to sedimentation phenomena in the valleys, where many of these places seem to have moved, making it difficult to perceive without excavations.
}

intermingling of internal and external factors. In terms of external factors, the climate change that occurred in the second half of the 3rd millennium BCE must be analysed, as well as the new genetic data and changes in exchange routes motivated by the transformations that occurred in southern societies. In terms of internal factors, the different cultural backgrounds of the two sub-regions and the forms of resistance or permeability to changes must also be considered.

\subsection{Climate change}

The late 4th and the 3rd millennia BCE were characterised by a period of neoglaciation. In the Northwest Iberian Peninsula this has been corroborated by geochemical data from analyses of peat bogs, that indicate temperatures between $2^{\circ} \mathrm{C}$ and $2.5^{\circ} \mathrm{C}$ lower than those currently existing (Martínez-Cortizas et al. 2009). These climatic conditions of neoglaciation (colder, drier and more windy) occurred between c. 3500 and $1500 \mathrm{BCE}$, with a constant temperature drop until $c$. 2500 BCE (mid 3rd millennium BCE), after which there was a slight thermal increase, again interrupted by a colder period between the mid and the third quarter of the 2nd millennium BCE (between 1600-1400 to c. 1200 $\mathrm{BCE})$. In terms of precipitation, there was a decrease from 2300-2200 BCE to about 1400-1300 BCE (Fábregas Valcarce et al. 2003; Martínez Cortizas et al. 2009) (Figure 12 ), which is, roughly, contemporary with that which has been defined as the $4.2 \mathrm{ka}$ BP aridification event (Dalfes et al. 1997), around 2300-1850 BCE. This climatic event resulted from long-term orbital forcing, which led to higher summer insolation and a cool Neoglacial period in mid latitudes (Rimbu et al. 2003; Wanner et al. 2008; Magny et al. 2009), although, according to Magny et al. (2009), three environmental phases can be distinguished within this period, which makes its articulation with archaeological data (Carroza et al. 2015) complex.

This period of colder and drier conditions, led to changes in vegetation cover, confirmed by the collection of pollen data from coastal and inland areas of the Northwest Iberian Peninsula. Between 2300$2200 \mathrm{BCE}$, for altitudes between 1000 and 1600 meters, these data reveal a gradual decay of the forest cover related to climate change and forest fires (MartínezCortizas et al. 2009; López-Sáez et al. 2011), although in low-lying areas a greater number of disturbance and synanthropic rate indicators (such as Erica, Polypodium vulgare, Pteridium aquilinum and Cichorioideae) are found, as well as increasing presence of macrocarbons related to erosive episodes, interspersed by natural forest fires (Carrión et al. 2010a; 2010b; López-Merino et al. 2010; 2012; Muñoz-Sobrino et al. 2004; 2012; Kaal et al. 2013; Pérez-Obiol et al. 2016). 


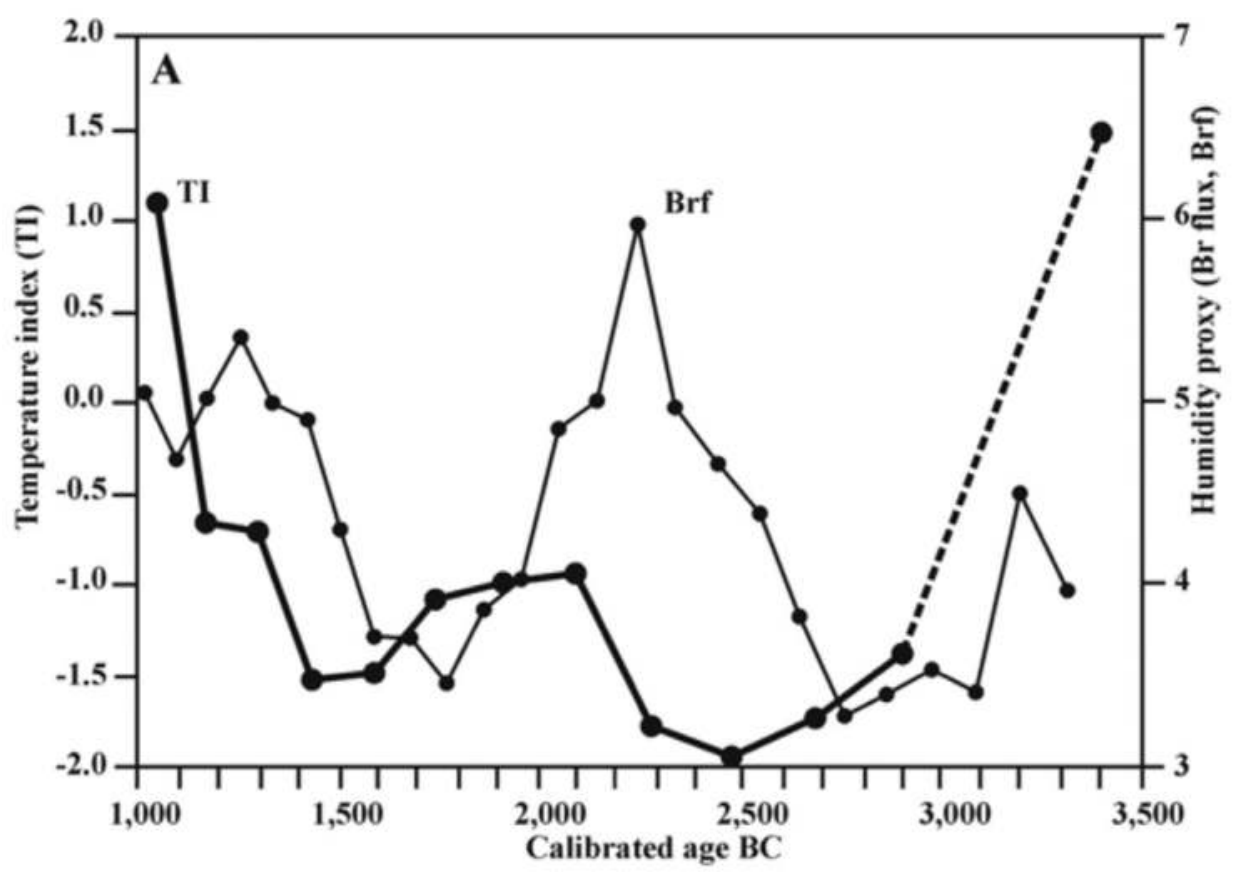

Figure 12. Climatic conditions between c. 3500 and 1000 BCE (Fábregas Valcarce et al. 2003).

But if these conditions are well known for the Atlantic sub-region of the Northwest Iberian Peninsula, or for higher altitudes in the Mediterranean sub-region, in this case strongly influenced by glacial and periglacial erosive phases, data is lacking for the lower interior regions, where settlement occurred, and environmental and geomorphological conditions were very different from the higher altitude regions (Martin Seijo et al. 2017a). This has been overcome by anthracological studies, which, despite certain constraints, and without providing detailed description of climate change, have provided an insight into the degradation of the forest cover at a local scale (the Sabor valley), revealing an increase in shrub species (Martin Seijo et al. 2017a). This degradation was clearly higher in this Mediterranean sub-region than in the Atlantic sub-region of the Northwest Iberian Peninsula (Martín-Seijo et al. 2012; 2015).

Comparison of climate conditions and settlement conditions has already been made in detail for the 3rd millennium BCE by Fábregas Valcarce et al. (2003), and, briefly, for the late 3rd millennium and the first half of the 2nd millennium BCE (Fábregas Valcarce 2010; Bettencourt 2013). It is now necessary to confront archaeological and climate data, more generally for the period under study. In this manner it can be seen that the rise in temperatures, which occurred after $2500 \mathrm{BCE}$, and with greater amplitude in $2300 \mathrm{BCE}$, favoured the increased settlement of higher altitude zones. This is evident in terms of camps or settlements in areas with pastoral potential, in the reappearance of funerary contexts that, after a major hiatus, once again occupied the great mountain plateaus in a generalised manner, and, also, the new wave of rocky outcrops engraved with weapons in irrigated areas of mid-tohigh altitude, at least on the Atlantic coast and coastal mountains. This does not invalidate the possibility that the populations continue to occupy valley contexts, in a new reorganisation of settlement that enabled greater economic complementarity. The dry conditions, however, experienced from 2300-2200 BCE onwards, were also a preponderant factor in the occupation of high altitude wetlands (settlements, tombs, engraved loci), as well as the occupation of the bottom of valleys (settlements, tombs, hoards), wherein, in both cases, there is evidence of single tombs or exceptional deposits, indicating the importance of controlling this important resource and the existence of a macro-structure where power, in a period of extreme drought, was linked to the real and supernatural control of water. The connection to water in the Atlantic sub-region of the Northwest Iberian Peninsula is such that even today it is common to hear the expression within agricultural communities that those who have water have power.

Hence, it is likely that climate change in the second half of the 3rd millennium BCE, with an increase in temperature from $2500 \mathrm{BCE}$, and more dryness from 2300-2200 BCE, may be significantly related to changes in settlement strategies, economy, society, and ideology, as verified in the Northwest Iberian Peninsula, contrary to that which has been defended by Blanco González et al. (2018). 
In the Mediterranean sub-region, whereas the increase in temperatures from the middle of the 3rd millennium BCE onwards would have enabled occupation of higher areas, such as Lorga de Dine (still located today in the so-called Terra Fria Transmontana), the existence of medium-altitude settlements, such as Cemitério de Mouros II and the maintenance or reoccupation of some high-altitude ceremonial sites. The greater anthropic pressure noted in the valleys, through anthracological analysis, suggests that the displacement of the settlement to low-lying areas, closer to watercourses, may have been more frequent than is currently known. This tendency of settlements, metallic hoards, and loci engraved with 'armed' weapons and stelae to be located nearer to watercourses must also be related to the period of greater dryness, once again indicating restructuring of settlement strategies, economy and society, which would have been articulated with the climate change that occurred during this generic period and with the $4.2 \mathrm{ka}$ BP aridification event. It should be noted that the innovative places of power negotiation, associated with the emergence of the new 'armed' ideology (Vale de Figueira 11, Pedra Escrita de Ridevides, and the stelae of Longroiva) are directly linked to water and the bottom of well-irrigated valleys, which existed alongside some old and new enclosures that rise as a phenomenon of autonomy and resistance to the new power logics.

\subsection{Genetic data}

In terms of external factors of change, genetic issues, such as those related to mtDNA, still need to be considered, despite the lack of discussion among archaeologists and archaeogeneticists of the dangers of 'complex scientific data and equally complex social processes collapsed into simple narratives which echo extremist ideas about European identity, even if unintentionally so' (Frieman and Hofmann 2019), and the problems related to the indicators used in these analyses that can lead to wide variation of data. ${ }^{30} \mathrm{In}$ recent research, it has been found that there were population contacts between the Iberian Peninsula and North Africa that enabled miscegenation, detected between the third quarter of the 3rd millennium BCE (Camino de las Yeseras, at San Fernando de Henares, Madrid, central Iberia) and the first quarter of the 2nd millennium BCE/Early Bronze Age (Loma del Puerco, at Chiclana, Cádiz, southern Iberia), although this had limited impact and does not appear to have extended beyond the centre of the Iberian Peninsula (GonzalezFortes et al. 2019; Olalde et al. 2019). In the eastern zone of the Northwest Iberian Peninsula, for example, the genetic results of the human remains found at Lorga de Dine, dated between the mid 3rd/beginning of

\footnotetext{
${ }^{30}$ One example is the possible impact of a migration during the Mesolithic-Neolithic transition on the European gene pool that has been a controversial subject for many years (Brandt 2017: 38-44).
}

the 2nd millennium BCE, do not indicate any genetic data of African origin (Gonzalez-Fortes et al. 2019), and therefore it may be assumed that this was not a factor of cultural change in this region. In the work by Olalde et al. (2019) it is also admitted that during the second half of the $3 \mathrm{rd}$ millennium BCE, about $40 \%$ of the population of Iberian descent was replaced by people of Pontic-Caspian ancestry, in almost 100\% of its Y-chromosomes. This essentially occurred in the centre and north, with little impact in the south. The authors of this work, therefore, consider that the populations associated with Pontic-Caspian ancestry would, after $2000 \mathrm{BCE}$, have been associated with the origins of the Bronze Age population. The absence of genetic data for the Northwest Iberian Peninsula does not currently enable us to consider a similar development for this geographical area.

\subsection{Interchange and trade}

Another factor of change that must be analysed is the role of interchange between populations, encompassing the circulation of people, goods, technologies, ideas and customs. In general, the archaeological data indicate a shift in the pattern of interchange, from the Mediterranean to the Atlantic axis, with greater expressiveness in the coastal areas, and only occasionally reaching the interior - a sub-region that seemed to maintain a greater link with continental areas or had greater autarchy.

The disintegration or collapse of the Chalcolithic system of southern communities, which began in the second half of the 3rd millennium BCE (e.g. SennaMartinez 2007; Carroza et al. 2015; Valera 2015; Soares 2020) would have been a major factor in the decrease in interactions between the south and the northwest, but it does not explain the new dynamism in Atlantic sub-regions, already defended by some authors based on the circulation of copper and gold objects (e.g. RuizGálvez Priego 1987; Needham 2015). What motivated these exchanges?

The Northwest Iberian Peninsula is rich in gold and copper. Copper was exploited in Asturias from the first half of the 3rd millennium BCE, and in Asturias and northern Castile during the second half of the same millennium. However Blas Cortina and SuárezFernández (2009) consider that the quantities of copper extracted would have been essentially for local consumption. But what can be considered to be local consumption? Did Asturias and northern Castile supply the copper needs of the entire Northwest Iberian Peninsula, at least after a certain moment in time? It should be noted that in many regions of Galicia and North Portugal there are copper ore deposits, including reserves of native copper, oxides and copper carbonates, capable 
of being used, and in quantities and abundance that could be profitably extracted at the time (Comendador Rey 1997; 1998; Van Schoor 2003). However, there is no evidence that these deposits were used. It should be noted that the copper mines at El Aramo were active until at least the middle of the 2nd millennium BCE and were not exhausted (Blas Cortina and Suárez Fernández 2009b). The same may have happened to many other mines that were explored in later periods and which it has not been possible to study in detail. It is also of note that the copper mines on Ross Island, in Killarney (southwest Ireland), ceased to be active by the end of the 3rd millennium BCE (O’Brien 1996; Lanting 2004). From this perspective it is possible that copper from the North/Northwest Iberian Peninsula, where it was abundantly mined, reached other Atlantic regions, such as Brittany or southwest Ireland, ${ }^{31}$ which were linked by ancestral contacts, since at least the Neolithic period. This could explain, for example, the appearance of Carrapatas-type halberds in hoards and the circulation of gold prototypes from Southwest Ireland found in the North/Northwest Iberian Peninsula, such as discs, lunula ${ }^{32}$ and strap necklaces, bracelets and rings. ${ }^{33}$ In this context, it should be noted that some pottery assemblages from the western zone of the Northwest Iberian Peninsula also had affinities with those of other Atlantic regions, namely with the western coast of France, Brittany and Southwest Ireland, which reveals deeper and more structural transformations than the adoption of simple metal artefacts for exchange. This is the case of the gentle S-shaped or sinuous profile pots with a cord under the rim, mainly in the neck, which are very common from the westernmost façade of Northwest Iberian Peninsula to the Ross Island copper mines.

On the other hand, the Northwest Iberian Peninsula was rich in sea salt, whose exploitation has been documented since, at least, the transition from the 3rd to the 2nd millennia BCE, from the coastal camp-site of Carreço/Praia (Bettencourt 1999; 2009; 2013) and the beginning of the 2nd millennium BCE at Areias Altas, Porto (Luz 2010), an important product for exchange (Bettencourt et al. 2020).

It must also be considered that, according to olalde et al. (2018), the arrival in Britain (from southeastern England to the western isles of Scotland) of people with large

\footnotetext{
${ }^{31}$ The confirmation of this hypothesis implies analysis of isotopes that compare data between multiple copper resources and copper objects.

32 These objects, in particular gold lunulae, are very common in Southwest Ireland, where they are considered to be an Irish innovation dating back to c. 2200-2000 BCE, according to Taylor (1970; 1980).

${ }^{33}$ The spatial distribution of these objects, from the coastal areas of the Iberian Peninsula to the French Atlantic coast (Blas Cortina 2013b), mainly in Brittany and Vendée (Briard 1965), do not provide arguments to help with their place of origin (Suaréz Otero 1991).
}

amounts of steppe-related ancestry after $2450 \mathrm{BCE}$ had a long-term demographic effect, causing a replacement of neolithic populations in the Bronze Age. Therefore, it is pertinent to ask whether the Northwest Iberian Peninsula may have accommodated populations fleeing from these regions? Or was it also affected by similar population changes? The continuity of genetic studies for this area will, in conjunction with archaeological data, be important in answering these questions.

In any event, during this period the Atlantic subregion of the Northwest Iberian Peninsula became more intensively connected with the Atlantic world, materialised through the emergence of new religious manifestations, new world views, new symbols of power, and the emergence, albeit tenuous, of individual expressions of power, which were manifested in a manner distinct from the previous period (stelae painted and engraved with weapons, cists or complex tombs with copper, long tanged daggers or short swords, sometimes with gold and copper traditional objects) that only occasionally appear to have reached the interior-most regions.

In the Mediterranean sub-region, the lack of inputs from the south led to the inability to produce or manipulate certain icons of power, such as copper artefacts, due to the absence of regions that traditionally supplied this ore. On the other hand, the products that the Northeast Iberian Peninsula could exchange, such as variscite, may have stopped being traded, which would have caused problems in the management and maintenance of power, which was not only based on agro-pastoral production (that perhaps was in crisis due to the marked dryness of the $4.2 \mathrm{ka}$ BP aridification event), but was also based on the control, exploration and supra-regional exchange of this local resource. In this reorganisation, which would have occurred from the second half of the $3 \mathrm{rd}$ millennium BCE, there seems to have been a greater consolidation of relations with the societies of the interior zones of the Meseta, along with certain inputs of Atlantic origin, introduced via the Douro basin. It should be noted that the León copper mine at La Profunda, Carménes, only started operating in the second half of the 3rd millennium BCE (26002300 BCE), which, according to Blas Cortina and Suárez Fernández (2009a), justified the intense settlement of this area during this period. This could explain the greater contacts with the Meseta, and, consequently, new dynamics and alliances that led to the adoption of new materiality, ideas and social structures.

\section{Final considerations}

Notwithstanding this synthesis, further data regarding certain aspects of the period under analysis, in particular the internal organisation of settlements, 
pottery collections, livelihood strategies, radiocarbon dating and genetic data, are required before an holistic discourse can be formalised on the communities of the last quarter of the 3rd millennium BCE in the Northwest Iberian Peninsula.

However, during this period, in the Atlantic sub-region, communities were already reorganised around new scenarios, icons and performances of affirmation and negotiation of power, implying the use of old icons and the manipulation of new ones, based on alliances and supra-regional interaction networks with the Atlantic world.

For this sub-region, it is therefore possible that the transition began in the third quarter of the 3rd millennium $B C E$, which is a period in which settlement is unknown, and new valleys and mountain territories were 'conquered' - a phenomenon that is perceptible, at least in terms of funerary contexts.

In the Mediterranean sub-region, the transition period towards a new social reorganisation seems to have occurred later, between 2200-2000 BCE, with characteristics of adaptability, resilience - perhaps motivated by phenomena of autarchy - and contacts with the Meseta Norte (interior North Spain), although slow and sporadic indicators of change have been seen since 2400-2200 BCE.

The Northwest Iberian Peninsula is, therefore, a region of profound heterogeneities and cultural asymmetries, with sub-areas guided by abrupt changes and others by changes in continuities, during the second half of the 3rd millennium BCE, which results from several different factors of change and different response phenomena to common factors, and where, at least, climatic change represents one major event that is associated with more or less specific events, providing a different sequence of cultural transformations.

\section{Acknowledgements}

The author would like to thank the editors for their invitation to present this chapter; Martin John Dale for the English proofreading of the final text; and Emílio Abad-Vidal for Figure 11.

\section{References}

Abad Gallego, J.C. 1992-1993. Balance de las actuaciones arqueológicas llevadas a caboen la necrópolis megalítica de Cotogrande (Cabral). (Campañas de 1989 a 1992). Castrelos 5-6: 7-28.

Abreu, M.E. 2012. Rock-Art in Portugal: History, Methodology and Traditions. Unpublished PhD thesis, University of Trás-os-Montes and Alto Douro.
Acuña Piñeiro, A, Barbeiro Pose, V. and Prieto Martínez, M.P. 2011. Setepías (Cambados, Pontevedra). Un ejemplo de arquitectura doméstica en la Edad del Bronce, in P.P. Martínez and L. Salanova (eds) Las comunidades campaniformes en Galicia. Cambios sociales en el III y II milenios BC en el $N W$ de la península ibérica: 13-24. Pontevedra: Diputación de Pontevedra.

Almagro Basch, M. 1972. Los ídolos y la estela decorada de Hernán Pérez (Cáceres) y el ídolo-estela de Tabuyo del Monte (León). Trabajos de Prehistoria 28: 83-124.

Alonso Mathias F. and Bello Dieguez J.M. 1995. Aportaciones del monumento de Dombate al megalitismo noroccidental: dataciones de Carbono $14 \mathrm{y} \mathrm{su}$ contexto arqueológico. Trabalhos de Antropologia e Etnologia 35(1): 153-181.

Alves, F.M. 1975. Memórias arqueológico-históricas do distrito de Bragança (2nd edition). Bragança: Museu do Abade de Baçal.

Alves, L.B. 2003. The movement of signs. Post-glacial rock art in North-western Iberia. Unpublished PhD thesis, University of Reading.

Alves, L.B. 2009. O sentido dos signos - reflexões e perspectivas para o estudo da arte rupestre PósGlaciar no Norte de Portugal, in B. Rodrigo Balbín (ed.) Arte Prehistórico al aire libre en el Sur de Europa: 381-490. Castilla y León: Consejeria de Cultura da Junta de Castilla y León.

Alves, L.B. and Comendador, B. 2009. Rochas e metais para além da físico-química, in A.M.S. Bettencourt and L.B. Alves (eds) Dos Montes, das Pedras e das Águas. Formas de Interacção com o Espaço Natural da Préhistória à Actualidade: 37-54. Braga: CITCEM/APEQ.

Baptista, A.M. 1983. O complexo de gravuras rupestres do Vale da Casa (Vila Nova de Foz Côa). Arqueologia 8: 57-69.

Baptista, J.M. 1992. As Indústrias Líticas Pré-Históricas do Litoral Minhoto. Contexto Cronoestratigráfico $e$ Paleoambiental. Cadernos de Arqueologia, Monografias 7. Braga: Unidade de Arqueologia da Universidade do Minho.

Baptista, L. 2004. A cerâmica do interior do recinto de Castelo Velho de Freixo de Numão - Contributos para a interpretação de contextos de uso. Unpublished Master's dissertation, University of Porto.

Barbosa, S. 1999. O Crasto de Palheiros-Murça. Contributo para o entendimento do fenómeno campaniforme em contexto doméstico no norte de Portugal. Unpublished Master's dissertation, University of Porto.

Bartholo, M.L. 1959. Alabardas da época do Bronze do Museu Regional de Bragança, in Actas e Memória do $1^{\circ}$ Congresso Nacional de Arqueologia, Lisboa 1958, vol. 1: 431-439. Lisboa: Instituto de Alta Cultura.

Bettencourt, A.M.S. 2000. 0 povoado da Idade do Bronze da Sola, Braga, Norte de Portugal (Cadernos de Arqueologia, Monografias 9). Braga: Unidade de Arqueologia da Universidade do Minho. 
Bettencourt, A.M.S. 2005a. O povoamento pré-histórico e proto-histórico da região de Cantanhede, in C.S. Cruz (ed.) Carta Arqueológica de Cantanhede: 245-248. Cantanhede: Câmara Municipal.

Bettencourt, A.M.S. 2005b. Os primeiros agricultores e pastores do Noroeste de Portugal: o Neolítico e o Calcolítico, in I. Silva and C. Mineiro (eds) D. Diogo de Sousa. Diogo de Sousa. Museu Regional de Arqueologia. Roteiro: 28-35. Lisboa: Instituto Português dos Museus.

Bettencourt, A.M.S. 2008. Life and death in the Bronze Age of the NW Iberian Peninsula, in F. Fahlander and T. Oestigaard (eds) The Materiality of Death - Bodies, Burials, Beliefs: 99-104. British Archaeological Reports International Series 1768. Oxford: Archaeopress.

Bettencourt, A.M.S. 2009a. A Pré-história do Minho: do Neolítico à Idade do Bronze, in P. Pereira (ed.) Minho. Traços de Identidade: 70-113. Braga: Conselho Cultural da Universidade do Minho.

Bettencourt, A.M.S. 2009b. Práticas Funerárias da Idade do Bronze de Trás-os-Montes e da Galiza Oriental, in J. Fonte (ed.) Actas do $1^{\circ}$ Congresso Transfronteiriço de Arqueologia: um Património sem Fronteiras (Barroso, Montalegre, 2008): 11-23. Revista Aquae Flaviae 41. Chaves: Grupo Cultural Aquae Flaviae.

Bettencourt, A.M.S. 2010a. La Edad del Bronce en el Noroeste de la Península Ibérica: una análisis a partir de las prácticas funerárias. Trabajos de Prehistoria 67(1): 139-173.

Bettencourt, A.M.S. 2010b. Comunidades pré-históricas da bacia do Leça, in J. Varela and C. Pires (eds) O Rio da Memória: Arqueologia no Território do Leça: 30-88. Matosinhos: Câmara Municipal.

Bettencourt, A.M.S. 2011. El vaso campaniforme en el Norte de Portugal. Contextos, cronologias y significados, in P. Prieto Martínez and L. Salanova (eds) Las comunidades campaniformes en Galicia. Cambios sociales en el III y II milenios BC en el NW de la Península Ibérica: 363- 374. Pontevedra: Diputación de Pontevedra.

Bettencourt, A.M.S. 2013. A Pré-história do Noroeste Português/The Prehistory of North-western Portugal (Territórios da Pré-história em Portugal), vol. 2. Bilingual edition. Braga/Tomar: CEIPHAR/CITCEM.

Bettencourt, A.M.S. 2017a. Post-palaeolithic rock arts of north-western Portugal; an approach, in A.M.S. Bettencourt, M. Santos-Estevez, H.A. Sampaio and D. Cardoso (eds) Recorded Places, Experienced Places. The Holocene Rock Art of the Iberian Atlantic Northwest: 123149. British Archaeological Reports International Series 2878. Oxford: BAR Publishing.

Bettencourt, A.M.S. 2017b. Gravuras rupestres do Noroeste para além das artes atlânticas e esquemática, in J.M Arnaud and A. Martins (eds) Arqueologia em Portugal - 2017. Estado da Questão: 10531067. Lisboa: AAP.

Bettencourt, A.M.S. 2021. West Iberian Bronze Age halberds in rock art sites: several ontological considerations, in A.M.S.Bettencourt, M. SantosEstévez and H. A. Sampaio (eds) Weapons and Tools in Rock Art. A World Perspective: 113-139. Oxford \& Philadelphia: Oxbow.

Bettencourt, A.M.S., Lemos, F.S. and Araújo, T. 2003. O complexo arqueológico de Vale Ferreiro, Serafão, Fafe (Norte de Portugal). Trabalhos de Antropologia e Etnologia 43(1-2): 113-132.

Bettencourt, A.M.S., Abad-Vidal, E. and Rodrigues, A. 2017 Cvarn - Rock Art Virtual Corpus of Northwestern Portugal. A multimedia tool to investigate and describe Post-palaeolithic rock art, in A.M.S. Bettencourt, M. Santos-Estévez, H.A. Sampaio and D. Cardoso (eds) Recorded Places, Experienced Places. The Holocene Rock Art of the Iberian Atlantic Northwest: 19-26. British Archaeological Reports International Series 2878. Oxford: BAR Publishing.

Bettencourt, A.M.S., Dinis, A., Cruz, C. and Silva, I.S. 2007a. A estação arqueológica de Bitarados, Vila Chã (Esposende-Norte de Portugal). Boletim Municipal de Esposende 1, série 2: 3-16.

Bettencourt, A.M.S., Rodrigues, A., Silva, I.S., Cruz, C.S. and Dinis, A. 2005. The ceremonial site of Vale Ferreiro, Fafe, in the context of the Bronze Age in Northwest of Portugal. Journal of Iberian Archaeology 7: 157-175.

Bettencourt, A.M.S.; Luz, S.; Oliveira, N.; Simões P.P.; Alves, M.I.C.; Abad-Vidal, E. 2020. Produção de sal marinho na Idade do Bronze do Noroeste Ibérico. Alguns dados para uma reflexão, in J.M. Arnaud, C. Neves and A. Martins (eds.) Arqueologia em Portugal 2020 - Estado da Questão: 987-1000. Lisboa: AAP.

Bettencourt, A.M.S., Dinis, A., Figueiral, I., Rodrigues, A., Cruz, C., Silva, I.S., Azevedo, M. and Barbosa, R. 2007b. A ocupação do território e a exploração dos recursos durante a Pré-História Recente do Noroeste de Portugal, in S.O. Jorge, A.M.S. Bettencourt and I. Figueiral (eds) A Concepção das paisagens e dos espaços na arqueologia da Península Ibérica. Actas do IV Congresso de Arqueologia Peninsular: 149-164. Faro: Centro de Estudos de Património, Departamento de História, Arqueologia e Património, Faculdade de Ciências Humanas e Sociais, Universidade do Algarve.

Blanco-González, A., Lillios, K., López-Saéz, J.A. and Drake, B.L. 2018. Cultural, Demographic and Environmental Dynamics of the Copper and Early Bronze Age in Iberia (3300-1500 BC): Towards an Interregional Multiproxy Comparison at the Time of the $4.2 \mathrm{ky}$ BP Event. Journal of World Prehistory 31(1): 1-79.

Blas Cortina, M.A. 1985. Piedrafita V. Nuevos aspectos sobre el polimorfismo de las arquitecturas funerárias prehistorias en el N-NO de la Península Ibérica. Arqueologia 12: 129-136.

Blas Cortina, M.A. 1996a. La primera minería metálica del norte peninsular: Las indicaciones del C-14 y la cronología prehistórica de las explotaciones 
cupríferas del Aramo y El Milagro. Complutum Extra 6(1): 217-226.

Blas Cortina, M.A. 1996b. La minería prehistórica y el caso particular de las explotaciones cupríferas de la sierra del Aramo. Arqueología y Antigüedad. Gallaecia 14-15.

Blas, M.A. 1998. Producción e intercambio de metal: la singularidad de las minas de cobre prehistóricasdel Aramo y El Milagro (Asturias), in G. Delibes (ed.) Minerales y metales en la Prehistoria Reciente. Algunos testimonios de su explotación y laboreo en la Península Ibérica: 71-103. Studia Archaeologica 88. Valladolid: Universidad de Valladolid y Fundación Duques de Soria.

Blas Cortina, M.A. 2003. La mina como ámbito infraterreno y el cadáver como ofrenda ritual. A propósito de los esqueletos humanos hallados en las explotaciones cupríferas del Aramo, in J.F. Manzano and J.I. Herrán Martínez (eds) Mineros y fundidores en el inicio de la Edad de los Metales: 32-48. León: Caja Madrid.

Blas, M.A. 2005.Un témoignage probant de l'exploitation préhistorique du cuivre dans la Péninsule Ibérique: le complexe minier d'El Aramo (Astu-ries), in P. Ambert and J. Vasea (eds) La première métallurgie en France et dans les pays limitrofes. Actes du colloque international, Carcassonne, 28-30 septembre 2002: 195205. Mémoire de la Société Préhistorique Française 37. Paris: Société Préhistorique Française.

Blas Cortina, M.A. 2013. IVo milénio a. de C.: los monumentos sepulcrales del Puerto de la Cobertoria (Quirós) y el domínio de las cumbres por las sociedades neolíticas, in P. Arias Cabal, M.A. Blas Cortina, M. Rasilla Vives and A. Villa Valdés (eds) De neandertales a albiones: cuatro lugares essenciales en la Prehistoria de Asturias: 69-138. Oviedo: Real Instituto de Estudios Asturianos.

Blas Cortina, M.A. de and Suárez Fernández, M. 2009a. Utillaje faunístico inédito de las labores de cobre prehistóricas de La Profunda (León) y su datación C14 (AMS), Zephyrus 64: 5-18.

Blas Cortina, M.A. and Suárez Fernández, M. 2009 b. Investigaciones arqueológicas de 2005 y 2006 en las minas de cobre prehistóricas de la sierra del Aramo, Texéu (Riosa), in Excavaciones Arqueológicas en Asturias 2003-2006: 421-435. Consejería de Cultura y Turismo del Gobierno del Principado de Asturias.

Bradley, R., Fábregas Valcarce, R., Alves, L. and Vilaseco Vázquez, X. 2005. El Pedroso, a prehistoric cave sanctuary in Castille. Journal of Iberian Archaeology 7: 125-156.

Brandt, G. 2017. Beständig ist nur der Wandel! Die Rekonstruktion der Besiedlungsgeschichte Europas während des Neolithikums mittels paläound populationsgenetischer Verfahren. Halle: Landesmuseum für Vorgeschichte.
Briard, J. 1965. Les Dépôts Bretons et l'Age du Bronze Atlantique. Rennes: Laboratoire d'Anthropologie Préhistorique de la Faculté des Sciences de Rennes.

Bueno Ramírez, P. 1983. Estatuas-menhir y armas en el Norte de la península Ibérica. Zephyrus 36: 153-158.

Bueno Ramirez, P. and Balbín Behrmann, R. 2005. Hiérarchisation et métallurgie: statues armées dans la Péninsule Ibérique. L'Anthropologie 109: 577-640.

Bueno Ramírez, P. and Fernández-Miranda, M. 1981. El Peñatú de Vidiago (Llanes, Asturias), in Altamira Symposium: 441-458. Madrid: Ministerio de Cultura.

Calo Lourido, F. and Gonzalez Reboredo, X.M. 1980. Estacion de arte rupestre de Leiro (Rianxo - A Coruna). Gallaecia 6: 207-216.

Canha, A., Henriques, F.R., Rosa, S. and António, T. 2018. O sítio da Eira (Vila Nova de Foz Côa), in N. Hernández Gutiérrez; J. Larrazabal Galarza and R. Portero Hernández (eds) Arqueología en el valle del Duero. Del Paleolítico a la Edad Media, vol. 6: 181-190. Valladolid: Glyphos Publicaciones.

Cardoso, D. 2015. A Arte Atlântica do Monte de S. Romão (Guimarães) no Contexto da Arte Rupestre Pós-paleolítica da Bacia do Ave - Noroeste Português. Unpublished PhD thesis, University of Vila Real e Trás-os-Montes.

Cardoso, J.L. 2005a. As cerâmicas campaniformes do povoado pré-histórico de Leceia (Oeiras): uma proposta de interpretação do fenómeno campaniforme na região do Estuário do Tejo, in D. Carvalho, D. Vila Maior and R.A. Teixeira (eds) Des(a) fiando discursos: Homenagem a Maria Emília Ricardo Marques: 151-157. Lisboa: Universidade Aberta.

Cardoso J.L. 2005b. Restos faunísticos do Crasto de Palheiros (Murça). Contributo para o conhecimento da alimentação no Calcolítico e na Idade do Ferro no Nordeste português. Portugália 26: 65-75.

Cardoso, J.L. 2014-2015. The Bell-beaker complex in Portugal: an overview, 0 Arqueólogo Português, série V, 4-5: 275-308.

Cardoso, J.L. and Soares, A.M.M. 1990/1992. Cronologia absoluta para o campaniforme da Estremadura e do Sudoeste de Portugal. O Arqueólogo Português, Série IV. 8-10: 203-228.

Cardoso, J.L. and Costa, C. 2004. A study of the faunal assemblage from the prehistoric enclosure of Castanheiro do Vento (Vila Nova de Foz Côa). Journal of Iberian Archaeology 6: 83-92.

Cardoso, J.L. and Bettencourt, A.M.S. 2008. Caça e pastorícia no Calcolítico do NW de Portugal: o caso da estação arqueológica de Bitarados. Estudos do Quaternário 5: 79-86.

Cardoso, J.M. 2007. Castanheiro do Vento (Horta do Douro, Vila Nova de Foz Côa) - um recinto monumental do III ${ }^{\circ}$ II ${ }^{\circ}$ milénios a.C.: problemática do sítio e das suas estruturas à escala regional. Unpublished $\mathrm{PhD}$ thesis, University of Porto.

Cardoso, J.M. 2014. A Idade do Bronze no Alto Douro Português: Os discursos possíveis, in S.S. Lopes (ed.) 
A Idade do Bronze em Portugal: Os dados e os problemas: 103-146. Tomar: Instituto Politécnico de Tomar.

Carrión, Y., Ntinou, M. and Badal, E. 2010a. Olea europaea L. in the north Mediterranean basin during the pleniglacial and the early-middle Holocene. Quat. Sci. Rev. 29 (7): 952-968.

Carrión, Y., Kaal, J., López-Sáez, J.A., López-Merino, L. and Martínez Cortizas, A. 2010b. Holocene vegetation changes in NW Iberia revealed by anthracological and palynological records from a colluvial soil. The Holocene 20: 53-66.

Carroza, L., Berger, J-F., Burens, A. and Marcigny, C. 2015. Society and environment in Southern France from the 3rd millennium $\mathrm{BC}$ to the beginning of the 2nd millennium BC: $2200 \mathrm{BC}$ a tipping point?, in $\mathrm{H}$. Meller, H. Wolfgang Arz, R. Jung and R. Risch (eds) 2200 BC - Ein Klimasturz als Ursache für den Zerfall der Alten Welt?/2200 BC - A climatic break-down as a cause for the collapse of the old world? 7th Archaeological Conference of Central Germany October 23-26, 2014 in Halle (Saale)/7. Mitteldeutscher Archäologentag vom 23. bis 26. Oktober 2014: 335-362. Tagungen des Landesmuseums für Vorgeschichte Halle 12. Halle: Landesmuseum für Vorgeschichte Halle (Saale).

Carvalho, A.F. 2003. O final do Neolítico e o Calcolítico no Baixo Côa (Trabalhos do Parque Arqueológico do Vale do Côa, 1996-2000). Revista Portuguesa de Arqueologia 6 (2): 229-273.

Carvalho, A.F. 2004. O povoado do Fumo (Almendra, Vila Nova de Foz Côa) e o início da Idade do Bronze no Baixo Côa (trabalhos do PAVC). Revista Portuguesa de Arqueologia 7(1): 185-219.

Cassen, S. and Vaquero Lastres, J. 2000. La Forme d'une chose, in S. Cassen, C. Boujot and J. Vaquero (eds) Eléments d'architecture (Exploration d'un tertre funéraire à Lannec er Gadouer, Erdeven, Morbihan. Constructions et reconstructions dans le Néolithique morbihannais. Propositions pour une lecture symbolique: 611-656. Ass. Publications Chauvinoises Mémoire 19. Chauvigny: Asso. Publications Chauvinoises.

Cassen, S., Rodríguez-Rellán, C., Fábregas Valcarce, R., Grimaud, V., Pailler, Y. and Schulz Paulsson, B. 2019. Real and ideal European maritime transfers along the Atlantic coast during the Neolithic. Documenta Praehistorica 46: 308-325.

Comendador Rey, B. 1997. La primera producción metalica del Noroeste Peninsular, in P. Bueno Ramírez and R. de Balbín Behrmann (eds) Actas do II Congreso Peninsular de Arqueología (Zamora), vol. 2: 509-516. Zamora: Fundación Rei Afonso Henriques.

Comendador Rey, B. 1998. Los inicios de la Metalurgia en el noroeste de la Península Ibérica (Brigantium 11). A Coruña: Castelo de San Anton Museo Arqueologico.

Costa, C. 2007. Zooarqueologia e tafonomia de Castanheiro do Vento. Unpublished Master's dissertation, University of Algarve.
Costa, C. 2008. Aspectos tafonómicos em Castanheiro do Vento (Vila Nova de Foz Côa) com base no estudo da arqueofauna. Promontoria Monográfica 6: 159-222.

Criado Boado, F., Amado Reino, X., Martínez López, M.C., Cobas Fernández, I. and Parcero-Oubiña, C. 2000. Programa de corrección del impacto arqueológico de la gasificación de Galicia. Un ejemplo de gestión integral del patrimonio arqueológico. Complutum 11: 63-85.

Cruz, C.M.S. 2005. Carta Arqueológica de Cantanhede. Cantanhede: Câmara Municipal.

Cruz, C.M.S., Bettencourt, A.M.S., Figueiredo, E. and Araújo, M.F. 2011. Achados metálicos de cobre no baixo Vouga (Centro-Norte de Portugal), in C. Martins, A.M.S. Bettencourt, J.I.F.P. Martins and J. Carvalho (eds) Povoamento e Exploração de Recursos Mineiros na Europa Atlântica Ocidental: 359-375. Braga: CITCEM/APEQ.

Cruz, D.J. 1992. A mamoa 1 de Chã de Carvalhal, no contexto arqueológico da Serra da Aboboreira. Coimbra: Instituto de Arqueologia da Faculdade de Letras de Coimbra.

Cruz, D.J. 1998. Expressões funerárias e cultuais no Norte da Beira Alta (V-II milénio a.C.), in A Pré-História na Beira Interior: 149-166. Estudos Pré-Históricos 6. Viseu: CCEPBA.

Cruz, D.J., Gomes, L.F.C. and Carvalho, P.M.S. 1998. Monumento 2 da Serra da Muna (Campo, Viseu). Resultados preliminares dos trabalhos de escavação, in Actas do Colóquio A Pré-História na Beira Interior (Tondela, 1997) (Estudos Pré-Históricos 6): 375-395. Viseu: CCEPBA.

Cruz Berrocal, M., García Sanjuán, L. and Gilman, A. 2013. The Prehistory of Iberia. Debating Early Stratification and the State. London: Routledge.

Dalfes, H.N., Kukla G. and Weiss H. 1997. Third Millennium BC Climate Change and old World Collapse, in Proceedings of the NATO Advanced Research Workshop on Third Millennium BC Abrupt Climate Change and old World Social Collapse, held at Kemer, Turkey, September 19-24, 1994: 1-49. Berlin/Heidelberg: Nato ASI Subser.

Delibes de Castro, G., Herrán, J.I., Santiago, J. and Val, J. 1995. Evidence for social complexity in the Copper Age of the northern Meseta, in K.T. Lillios (ed.) The origins of complex societies in Late Prehistoric Iberia: 4463. Ann Arbor: University of Michigan Press.

Fábregas Valcarce, R. 2001. Os petróglifos e o seu contexto: un exemplo da Galicia meridional. Vigo: Instituto de Estudos Viguenses.

Fábregas Valcarce, R. 2010. Os petróglifos e o seu contexto: un exemplo da Galicia meridional (2nd revised ed). Vigo: Instituto de Estudos Viguenses.

Fábregas Valcarce, R. and F. Fuente Andrés 1988. Aproximaciones a la cultura material del megalitismo gallego: la industria lítica pulimentada y el material cerámico. Arqueohistórica 2. Santiago de Compostela: Universidade de Santiago de Compostela. 
Fábregas Valcarce, R. and Vilaseco Vázquez, X.I. 2004. El megalitismo gallego a inicios del siglo XXI. Mainake 26: 63-87.

Fábregas Valcarce, R. and Rodríguéz-Rellan, C. 2019. Palazuelo de las Cuevas and the exploitation of variscite in the northwest of Iberia, in G. Querré, S. Cassen and E. Vigier (eds) La parure en Callaïs du Néolithique Europée: 59-70. Oxford: Archaeopress.

Fábregas Valcarce, R., Rodríguez Rellán, C. and Rodríguez Álvarez, E. 2009. Representacíons de armas no interior de Galicia (Comarca de Deza, Pontevedra). Unha reflexión sobre a distribución e cronoloxía destes motivos. Galaecia 28: 49-68.

Fábregas Valcarce R., Lombera Hermida, A. and Rodríguez Rellán, C. 2012. Spain and Portugal: long chisels and perforated axes. Their context and distribution, in P. Pétrequin, S. Cassen, M. Errera, L. Klassen and A. Sheridan (eds) Jade. Grandes haches alpines du Néolithique européen. $V^{\mathrm{e}}$ et IV millénaires av. J.-C : 1108-1135. Besançons: Presses Universitaires de Franche-Comté.

Fábregas Valcarce, R., Martínez Cortizas A., Blanco Chao, R. and Chesworth, W. 2003. Environmental change and social dynamics in the second-third millennium BC in NW Iberia. Journal of Archaeological Science 30(7): 859-871.

Fernández Rodríguez, C. 2000. Los macromamíferos en los yacimientos arqueológicos del Noroeste peninsular: un estudio económico. Unpublished $\mathrm{PhD}$ thesis, University of Santiago de Compostela.

Fernández Rodríguez, C. and Ortiz, L.P. 2007. Caza y domesticación en el Noroeste de la Península Ibérica durante la Prehistoria. Datos arqueozoológicos, in S.O. Jorge, A.M.S. Bettencourt and I. Figueiral (eds) A Concepção das paisagens e dos espaços na arqueologia da Península Ibérica. Actas do IV Congresso de Arqueologia Peninsular: 165-176. Faro: Centro de Estudos de Património, Departamento de História, Arqueologia e Património, Faculdade de Ciências Humanas e Sociais, Universidade do Algarve.

Ferreira, A.B. 2005. Geomorfologia do Maciço Antigo, in C.A. Medeiros (ed.) Geografia de Portugal. 0 ambiente físico: 75-102. Lisboa: Círculo de Leitores.

Ferreira, M.D., Silva, V., Lima, M.F. and Leal Gomes, C. 1999. Anatomia de algumas ocorrências de gemas e seu enquadramento em protocolos de ordenamento territorial - contributo para uma reflexão sobre o estatudo dos depósitos gemiferos portugueses. Cadernos Laboratorío Xeolóxico de Laxe 24: 31-44.

Figueiral, I. and Sanches, M.J. 1998/1999. A contribuição da antracologia no estudo dos recursos florestais de Trás-os-Montes e Alto Douro durante a Pré-história Recente. Portugália 19-20: 71-101.

Figueiral, I. and Sanches, M.J. 2003. Eastern Trás-osMontes (NE Portugal) from the late prehistory to the Iron age, in E. Fouache (ed.) The Mediterranean World Environment and History: 315-329. Paris: Elsevier SAS.
Figueiredo, S. 2013. A Arte Esquemática do Nordeste Transmontano: Contextos e Linguagens. Unpublished PhD thesis, University of Minho.

Fortes, J. 1908. A sepultura da Quinta da Água Branca (Edade do Cobre). Portugália 2(2): 241-252.

Frieman, C.J. and Hofmann, D. 2019. Present pasts in the archaeology of genetics, identity, and migration in Europe: a critical essay. World Archaeology. https:// doi.org/10.1080/00438243.2019.1627907.

García Sanjuán, L. 2017. Farming economy and wealth economy in the Copper Age of the Lower Guadalquivir river. Debating strategic resources at Valencina de la Concepción (Seville, Spain), in M. Bartelhein, P. Bueno Ramírez and M. Kunst (eds) Key resources and socio-cultural developments in the Iberian Chalcolithic: 237-256. Tübingen: Library Publishing.

Garrido Pena, R., Rojo Guerra, M.Á. and García Martínez de Lagrán, I. 2006. Un peculiar vaso campaniforme de estilo marítimo del túmulo de la sima, Miño de Medinaceli (Soria, España) reflexiones en torno a las técnicas decorativas campaniformes y los sistemas de intercambios a larga distancia. Tabajos de Prehistoria 63(1): 133-147.

Gaspar, R., Carrondo J., Nobre, L., Rodrigues, Z. and Donoso, G. 2014a. Espaço para a morte. O terraço da foz do Medal (vale do Sabor, Nordeste de Portugal) durante a Idade do Bronze. Estudos do Quaternário 10: 59-72.

Gaspar, R., Ribeiro, R., Rebelo, P., Neto, N. and Carvalho, M.L. 2014b. Bronze Age funerary contexts in Northeast Portugal. Terraço das Laranjeiras (Sabor Valley), in A.M.S Bettencourt, B. Comendador, H.A. Sampaio and E. Sá (ed.) Corpos e Metais na Fachada Atlântica da Ibéria. Do Neolítico à Idade do Bronze: 4962. Braga: CITCEM.

Gianotti, C. and Cancela, C. 2005. Testimuña da ocupacion humana durante o Neolítico Final e o período Alto-medieval na península do Morrazo, in F. Criado-Boado and E. Cabrejas Domínguez (eds) Obras públicase patrimonio: estudo arqueolóxico do Corredor do Morrazo: 50-54. TAPA 35. Santiago de Compostela: Instituto de Estudios Gallegos Padre Sarmiento, Consejo Superiorde Investigaciones Científicas.

Gianotti, C., Mañana-Borrazás, P., Criado-Boado, F. and López-Romero, E. 2011. Deconstructing Neolithic Monumental Space: the Montenegro Enclosure in Galicia (Northwest Iberia). Cambridge Archaeological Journal 21(3): 391-406.

Gilman, A. 2013. Were there States during Later Prehistory of Southern Iberia?, in M. Cruz Berrocal, L. García Sanjuán and A. Gilman (eds) The Prehistory of Iberia. Debating early social stratification and the State: 10-28. London: Routledge.

Gómez Fernandez, A., Fábregas Valcarce, R. and Peña Santos, A. 2001. Pasaron 20 años: las escavaciones del yacimiento de Lavapés (Cangas do Morrazo). 
Boletín del Seminario de Estudios de Arte y Arqueogía 67: 9-27.

Gómez Fernandez, A., Fábregas Valcarce, R., Méndez Vázquez, D. and Paz Rodriguez, M.S. 2004. Nuevos datos sobre cerámica Penha en el Sur de Galicia. Sautuola 10: 17-33.

Gonzalez-Fortes G., Tassi F., Trucchi E., Henneberger K., Paijmans J.L.A., Diez Del Molino D., Schroeder H., Barroso-Ruiz C., Bermudez F., Barroso-Medina C., Bettencourt A.M.S., Sampaio H.A., GrandalD’Anglade A., Salas A., De Lombera A., Fabregas R., Vaquero, M., Alonso, S., Lozano, M., RodríguezAlvarez, X.P., Fernández-Rodríguez, C., Manica, A., Hofreiter, M. and Barbujani, G. 2019. A Western route of prehistoric human migration from Africa into the Iberian Peninsula. Proceedings of the Royal Society B: Biological Sciences 20: 182-288.

González Méndez, M. 1992. Yacimientos del III milénio a.C.: entre la problemática del Calcolítico y un passado huidizo, in F. Criado Boado (ed.) Arqueología del paisage. El area Bocelo-Furelos entre los tiempos paleolíticos y medievales (campañas de 1987, 1988, 1989): 142-172. Arqueoloxía/Investigación 6. Santiago de Compostela: Xunta de Galicia.

González Méndez, M. 2000. La revalorización del patrimonio arqueológico. La defenición de un programa para el ayuntamiento de Toques (A Coruña). Arqueoloxía/ Investigación 8. A Coruña: Xunta de Galícia.

Harpsoe, C.H. and Ramos, M.F. 1985. Lorga de Dine (Vinhais, Bragança). Arqueologia 12: 202-204.

Hedges, R.E.M., Pettit, P.B., Ramsey, B.C.B. and Van Klinken, G.J. 1998. Radiocarbon dates from the Oxford AMS system: Archaeometry datelist 26. Archaeometry 40: 437-455.

Jorge, S. 1986. Povoados da Pré-história Recente da região de Chaves-Vila Pouca de Aguiar (Trás-os-Montes Ocidental): bases para o conhecimento do $I I^{\circ}$ e princípios do $I I^{\circ}$ milénios a. C. no Norte de Portugal. Porto: Instituto de Arqueologia da Faculdade de Letras.

Jorge, S. 1994. Colónias, fortificações, lugares monumentalizados. Trajectória das concepções sobre um tema do Calcolítico peninsular. Revista da Faculdade de Letras 11: 447-546.

Jorge, S. 1999. Cabeço da Minha (Vila Flor, Portugal): a Late Prehistoric sanctuary with 'stelai' of the Iberian Peninsula, in Gods and Heroes of the Bronze Age. Europe at the time of Ulysses: 137-141. London: Thames and Hudson.

Jorge, S. 2002. An all-over corded Bell Beaked in northern Portugal. Castelo Velho de Freixo de Numão. Some remarques. Journal of Iberian Archaeology 4: 107-130.

Jorge, S. 2005. O passado é redondo. Dialogando com os sentidos dos primeiros recintos monumentais. Porto: Edições Afontamento.

Jorge, S. 2014. Enclosures and funerary practices: about an archaeology in search for the symbolic dimensions of social relations, in A.C. Valera (ed.) Recent Prehistoric Enclosures and Funerary Practices in Europe: 71-82. British Archaeological Reports International Series 2676. Oxford: Archaeopress.

Jorge, S.O. and Rubinos, A. 2002. Cronologia absoluta de Castelo Velho de Freixo de Numão: os dados e os problemas. Côavisão 4: 95-111.

Jorge, S.O., Oliveira, M.L.C., Nunes, S. and Gomes, S. 1998-1999. Uma estrutura ritual com ossos humanos no sítio pré-histórico de Castelo Velho de Freixo de Numão (V $\mathrm{N}^{\mathrm{a}}$ de Foz Côa). Portugália 19-20 : 29-70.

Jorge, V.O. 1980. Escavação da Mamoa 1 de Outeirode Gregos. Serra da Aboboreira, Baião. Portugália 1: 9-28.

Jorge, V.O. 1982. Megalitismo do Norte de Portugal: o distrito do Porto. Os monumentos e a sua problemática no contexto europeu. Unpublished PhD thesis, University of Porto.

Jorge, V. and Jorge S.O. 1990. Statues-menhirs et steles du Nord du Portugal, in J. Briard and A. Duval (eds) Les representations humaines du néolithique á l'Âge du Fer: 29-43.Paris: CTHS.

Jorge, V.O., Alonso, F. and Delibrias, G. 1988. Novas datas de Carbono 14 para mamoas da Serra daAboboreira. Arqueologia 18: 95-98.

Jorge, V.O., Cardoso, J.M., Pereira, L.S and Coixão, A.S. 2002. Castanheiro do Vento, um sítio monumental pré-histórico do Concelho de Vila Nova de Foz Côa (Horta do Douro). Côavisão 4: 73-93.

Jorge, V.O., Cardoso, J.M., Pereira, L.S. and Coixão, A.S. 2003. A propósito do recinto monumental de Castanheiro de Vento (V.a N.a de Foz Côa), in S.O. Jorge (ed.) Recintos Murados da Pré-História Recente: 79-113. Porto/Coimbra: DCTP, FLUP, CEAUCP.

Kaal, J., Carrión, Y., Asouti, E., Martín Seijo, M., Martínez Cortizas, A., Costa Casáis, M. and Criado Boado, F. 2011. Long-term deforestation in NW Spain: linking the Holocene fire history to vegetation change and human activities. Quaternary Science Reviews 30 (1-2): 161-175.

Kaal, J., Criado-Boado, F., Costa-Casais, M., LópezSáez, J.A., López-Merino, L., Mighall, T., Cariín, Y., Silva Sánchez, N. and Martínez Cortizas, A. 2013. Prehistoric land use at an archaeological hot-spot (the rock art park of Campo Lameiro, NW Spain). Journal of Archaeological Science 40: 1518-1527.

Lanting, J.N. 2004. Ross Island: radiocarbon dates and absolute chronology, in W. O'Brien (ed.) Ross Island. Mining, metal and society in the Early Ireland: 305-316. Galway: University of Ireland.

Lautensach, H. 1967. Geografia de España y Portugal. Barcelona: Edit. Vicens-Vives.

Lopes, S.S. 2019. Voltar a Castelo Velho de Freixo de Numão: pensar a reconfiguração cultural de um recinto pré-histórico do Alto Douro Português, in S.S. Lopes (ed.) Olhares sobre Castelo Velho de Freixo de Numão: revisitar um recinto pré-histórico do Alto Douro: 357-389. Digitar. Revista Digital de Arqueologia, Arquitecturas e Artes: extra 1. Coimbra: CEAUCP. 
Lopes, S.S. and Bettencourt, A.M.S. 2017. Para uma periodização da Pré-história Recente do Norte de Portugal: da segunda metade do $4^{\circ}$ milénio aos finais do $3^{\circ}$ milénio AC., in J.M. Arnaud and A. Martins (eds) Arqueologia em Portugal-2017. Estado da Questão: 467-487. Lisboa: Associação dos Arqueólogos Portugueses.

López-Merino, L., Martínez Cortizas, A. and López-Sáez, J.A. 2010a. Early agriculture and palaeoenvironmental history in the North of the Iberian Peninsula: a multi-proxy analysis of the Monte Areo mire (Asturias, Spain). Journal of Archaeological Science 37(8): 1978-1988.

López-Merino, L., Silva Sánchez; Kaal, J., López-Sáez, J.A. and Martínez Cortizas, A. 2010b. Post-disturbance vegetation dynamics during the Late Pleistocene and the Holocene: An example from NW Iberia. Global and Planetary Change 92-93: 58-70.

López-Merino, L., Silva Sánchez, N., Kaal, J., LópezSáez, J.A. and Martínez-Cortizas, A. 2012. Postdisturbance vegetation dynamics during the late Pleistocene and the Holocene: an example from NW Iberia. Global Planetary Change 92-93: 58-70.

López Plaza, S. and Santos, J. 1984-1985. Alabarda y puñales de lengüeta y remaches procedentes del S. O. de la Cuenca del Duero. Zephyrus 37-38: 255-266.

López Romero, E., Güimil Fariña, A., Mañana-Borrazás, P., Otero Vilariño, C., Prieto Martínez, P., Rey García, J.M.P. and Vilaseco Vázquez, X.I. 2015. Ocupación humana y monumentalidad durante la Prehistoria Reciente en el islote de Guidoiro Areoso (Ría de Arousa, Pontevedra): investigaciones en el marco de las dinámicas litorales atlánticas actuales. Trabajos de Prehistoria 72(2): 353-371.

López-Sáez, J.A., Carrión-Marco, Y., López-Merino, L., Kaal, J., Costa-Casais, M. and Martínez-Cortizas, A. 2011. Cambios ambientales en el Noroeste peninsular durante el Campaniforme (2800-1400 cal BC), in P. Prieto and L. Salanova (eds) Las comunidades campaniformes en Galicia: cambios sociales en el III y II milenios BC en el NW de la Península Ibérica: 375-381. Pontevedra: Diputación de Pontevedra.

Loureiro, L. 2017. O recinto calcolítico da Forca (Maia). Unpublished Master's dissertation, University of Minho.

Luz, S. 2010. Depósito de conchas do sítio arqueológico das Areias Altas (Porto, Portugal). Discussão do enquadramento arqueológico da estrutura 15. Férvedes 6: 141-145.

Magny, M., Vannière, B., Zanchetta, G., Fouache, E., Touchais, G., Petrika L., Coussot, C., WalterSimonnet, A.-V. and Arnaud, F. 2009. Possible complexity of the climatic event around 4300-3800 cal. BP in the central and western Mediterranean. Holocene 19(6), 823-833.

Martín-Seijo, M., Bettencourt, A.M.S., Abad Vidal, E. and López García, J.C. 2012. Firewood and timber exploitation during the third and second millennia BC in North-western Iberia: wood resources, territories and chaîne opératoire, in A.C. Almeida, A.M.S. Bettencourt, D. Moura, S. Monteiro-Rodrigues and M.I.C. Alves (eds) Environmental Changes and Human Interaction along the Western Atlantic Edge: 115135. Coimbra: APEQ, CITCEM, CEGOT, CCT/CGUP.

Martín-Seijo, M., Tereso, J.P., Vaz, F.C., Gaspar, R. and Rodríguez Rellán, C. 2017a. Early-Middle Bronze Age communities and wood resources management in northeast Portugal: the Sabor valley. Quaternary International 458: 28-43.

Martín-Seijo, M., Tereso, J.P., Bettencourt, A.M.S., Sampaio, H.A., Abad, E. and Vidal, L. 2017b. Socioecology of Early and Middle Bronze Age communities in the north-west Atlantic region of Iberia: wood resources procurement and forest management. Quaternary International 437: 90-101.

Martín-Seijo, M., Blanco-González, A., Teira-Brión, A., Rodríguez Rellán, C., Bettencourt, A.M.S., Rodríguez Sáiz, E. and Comendador Rey, B. 2017c. Disentangling the life-cycles of Bronze Age pits: a multi-stranded approach, integrating ceramic refitting, archaeobotany and taphonomy. Journal of Archaeological Sciences: Report 12: 528-542.

Martínez-Cortizas, A., Costa-Casais, M. and LópezSáez, J.A. 2009. Environmental change in NW Iberia between 7000 and $500 \mathrm{cal} \mathrm{BC}$. Quaternary International 200: 77-89.

Martínez-Cortizas, A., López-Merino, L., Bindler, R., Mighall, T. and Kylander, M.E. 2015. Early atmospheric metal pollution provides evidence for Chalcolithic/Bronze Age mining and metallurgy in Southwestern Europe. Science of the Total Environment 545-546: 398-406.

Meijide Cameselle, G. 1989. Un importame conjunto del Bronce Inicial en Galicla: el deposito de Leiro (Rianxo, A Coruna). Gallaecia 11: 151-164.

Méndez Fernández, F. 1994. La domesticacón del paisaje durante la edad del Bronce galego. Trabajos de Prehistoria 51(1): 77-94.

Méndez Fernández, M. 1995. Areas de acumulación: un modelo de yacimiento habitacional para la edad del bronce en Galicia, in Actas del XXII Congreso Nacional de Arqueología, Vigo 1993, vol. 2: 69-74. Vigo: Xunta de Galicia.

Mighall, T.M., Martínez Cortizas, A., Biester, H. and Turner, S.E. 2006. Proxy climate and vegetation changes during the last five millennia in NW Iberia: pollen and non-pollen palynomorph data from two ombrotrophic peat bogs in the North Western Iberian Peninsula. Review of Palaeobotany and Palynology 141(1-2): 203-223.

Muñoz-Sobrino, C., Ramil Rego, P. and Gómez-Orellana, L. 2004. Vegetation of the Lago de Sanabria area (NW Iberia) since the end of the Pleistocene: a palaeoecological reconstruction on the basis of 
two new pollen sequences. Vegetation History and Archaeobotany 13(1): 1-22.

Muñoz-Sobrino, C., Ramil Rego, P. and Gómez-Orellana, L. 2007. Late Würm and early Holocene in the mountains of northwest Iberia: biostratigraphy, chronology and tree colonization. Vegetation History and Archaeobotany 16: 223-240.

Muñoz-Sobrino, C., Ramil Rego, P. and Gómez-Orellana, L. and Díaz Varela, R. 2005. Palynological data on major Holocene climatic events in NW Iberia. Boreas 34: 381-400.

Muñoz-Sobrino, C., Suárez Pérez, F.J., Nava Fernández, H.S., Fernández Casado, M.A., Gómez-Orellana, L., Rodríguez-Guitián, M.A., Fernández Prieto, J.A. and. Ramil-Rego, P. 2012. Environmental changes in the westernmost Cantabrian Range during the postglacial period: the Pena velosa (Muniellos, Asturias) pollen record, in A.C. Almeida, A.M.S. Bettencourt, D. Moura, S. Monteiro-Rodrigues and M.I. Caetano Alves (eds). Environmental changes and human interaction along the western Atlantic edge: 7994. Coimbra: APEQ / CITCEM / CEGOT / CGUP/CCT.

Muralha, J., Vale, A., Gomes, S. and Jorge, V.O. 2018. A Intervenção Arqueológica em Castanheiro do Vento: campanha de 2017. CôaVisão 20: 73-84.

Muralha, J., Vale, A., Gomes, S. and Jorge, V.O. 2019. Relatório dos trabalhos arqueológicos em Castanheiro do Vento 2018. CôaVisão 21: 39-47.

Needham, S., Davis, M., Gwilt, A., Lod-Wick, M., Parkes, P. and Reavill, P. 2015. A hafted halberd excavated at Trecastell, Powys: from under-current to uptake - the emergence and contextualisation of halberds in Wales and North-west Europe. Proceedings of the Prehistoric Society 81: 1-42.

Nocete, F. 2001. Tercer milenio antes de nuestra era. Relaciones y contradicciones centro/periferia en el Valle del Guadalquivir. Barcelona: Bellaterra.

Nocete, F., Alex, E; Nieto, J.M., Sáez, R. and Bayona, M.R. 2005. An archaeological approach to regional environment pollution in the south-western Iberian Peninsula related to third millennium $\mathrm{BC}$ mining and metallurgy. Journal of Archaeological Science 32: 1566-1576.

O'Brien, W. 1996. Bronze Age Copper Mining in Britain an Ireland. Buckinghamshire: Shire Publications.

O'Brien, W. 2015. Prehistoric copper mining in Europe: 5500-500 BC. Oxford: Oxford University Press.

Odriozola, C.P., Sousa, A.C., Boaventura, R. and Villalobos, R. 2013. Componentes de adornos de pedra verde de Vila Nova de São Pedro (Azambuja): Estudo de proveniências e redes de troca do $3^{\circ}$ milénio A.N.E. no actual território portugués, in J. Morais, A. Martins and C. Neves (eds) Arqueologia em Portugal: 150 anos: 457-462. Lisboa: AAP.

Olalde, I., Brace, S., Allentoft, M.E., Armit, I., Kristiansen, K., Rohland, N., Mallick, S., Booth, T., Szécsényi-Nagy, A., Mittnik, A., Altena, E., Lipson, M., Lazaridis, I.,
Patterson, N., Broomandkhoshbacht, N., Diekmann, Y., Faltyskova, Z., Fernandes, D., Ferry, M., Harney, E., de Knijff, P., Michel, M., Oppenheimer, J., Stewardson, K., Barclay, A., Alt, K.W., Avilés, A., Bánkky, E., Bernabò-Brea, M., Lilloin, D., Blasco, C., Bonsall, C., Bonsall, L., Allen, T., Büster, L., Carver, S., Navarro, L.C., Craig, O.E., Cook, G.T., Cunliffe, B., Denaire, A., Dinwiddy, K.E., Dodwell, N., Ernée, M., Evans, C., Kuchaík, M., Francès, J., Fokkens, H., Fowler, C., Gazenbeek, M., Garrido, R., Haber-Uriarte, M., Haduch, E., Hey, G., Jowett, N., Knowles, T., Massy, K., Pfrengle, S., Lefranc, P., Lemercier, O., Lefebvre, A., Lomba, J., Majó, T., Mckinley, J.I., Mcsweeney, K., Gusztáv, M.B., Modi, A., Kulcsár, G., Kiss, V., Czene, A., Patay, R., Endrdi, A., Köhler, K., Hajdu, T., Cardoso, J.L., Lieseau, C., Parker Pearson, M., Wlodarczak, P., Price, T.D., Prieto, P., Rey, P.-J., Ríos, P., Risch, R., Rojo, M.A., Schmitt, A., Serralongue, J., Silva, A.M., Smrčka, V., Vergnaud, L., Zilhão, J., Caramelli, D., Higham, T., Heyd, V., Sheridan, A., Sjögren, K.G., Thomas, M.G., Stockhammer, P.W., Pinhasi, R., Krause, J., Haak, W., Barnes, I., Lalueza-Fox, C. and Reich, D. 2018. The Beaker phenomenon and the genomic transformation of northwest Europe. Nature 555: 190-196.

Olalde, I., Mallick, S., Patterson, N., Rohland, N., Villalba-Mouco, V., Silva, M., Dulias, K., Edwards, C.J., Gandini, F., Pala, M., Soares, P., Ferrando-Bernal, M., Adamski, N., Broomandkhoshbacht, N., Cheronet, O., Culleton, B.J., Fernandes, D., Lawson, A.M., Mah, M., Oppenheimer, J., Stewardson, K., Zhang, Z., Jiménez Arenas, J.M., Toro Moyano, I.J., SalazarGarcía, D.C., Castanyer, P., Santos, M., Tremoleda, J., Lozano, M., García Borja, P., Fernández-Eraso, J., Mujika-Alustiza, J.A., Barroso, C., Bermúdez, F.J., Viguera Mínguez, E., Burch, J., Coromina, N., Vivó, D., Cebrià, A., Fullola, J.M., García-Puchol, O., Ignacio Morales, J., Oms, F.X., Majó, T., Vergès, J.M., DíazCarvaja, A., Ollich-Castanyer, I., López-Cachero, F.J., Silva, A.M., Alonso-Fernández, C., Delibes de Castro, G., Echevarría, J.J., Moreno-Márquez, A., Pascual Berlanga, G., Ramos-García, P., Ramos-Muñoz, J., Vijande Vila, E., Aguilella Arzo, G., Esparza Arroyo, A., Lillios, K.T., Mack, J., Velasco-Vázquez, J., Waterman, A., Lugo Enrich, L.B., Benito Sánchez, M., Agustí, B., Codina, F., de Prado, G., Estalrrich, A., Fernández Flores, A., Finlayson, C., Finlayson, G., Finlayson, S., Giles-Guzmán, F., Rosas, A., Barciela González, V., García Atiénzar, G., Hernández Pérez, M.S., Llanos, A., Carrión Marco, Y., Collado Beneyto, I., LópezSerrano, D., Sanz Tormo, M., Valera, A.C., Blasco, C., Liesau, C., Ríos, P., Daura, J., Pedro Michó, M.J., DiezCastillo, A.A., Flores Fernández, R., Francès Farré, J., Garrido-Pena, R., Gonçalves, V.G., Guerra-Doce, E., Herrero-Corral, A.M., Juan-Cabanilles, J., LópezReyes, D., McClure, S.B., Merino Pérez, M., Oliver Foix, A., Sanz Borràs, M., Sousa, A.C., Vidal Encinas, 
J.M., Kennett, D.J., Richards, M.B., Alt, K.W., Haak, W., Pinhasi, R., Lalueza-Fox, C. and Reich, D. 2019. The genomic history of the Iberian Peninsula over the past 8000 years. Science 363(6432): 1230-1234.

Ontañón Peredo, R. 2003. Caminos hacia la complejidad: el Calcolítico en la región cantábrica. Santander: Universidad de Cantabria, Fundación Marcelino Botín.

Parcero Oubiña, C. 1997. Documentación de un entorno castreño: trabajos arqueológicos en el área de Cameixa. TAPA 1:1-15.

Peña Santos, A. 1979. Notas para una revisión de los grabados rupestres de O Castriño en Conxo, Santiago de Compostela. El Museo de Pontevendra 33: 69-100.

Peña Santos, A. 2001. Ideología y sociedade en los grabados rupestres galaicos. Quaderns de Prehistòria $i$ Arqueologia de Castelló 22: 235-266.

Pereira, G.R. 2014. A sepultura sob tumulus do Senhor dos Aflitos (Alvarenga/Arouca, Centro-Norte de Portugal). Primeiros resultados. Estudos do Quaternário 10: 3-14.

Pereira, G.R., 2018. O monumento sob tumulus da Regedoura 2 (Fafe/NO Portugal), in N. Hernández Gutiérrez, J. Larrazabal Galarza and R. Portero Hernández (eds) Arqueología en el valle del Duero. Del Paleolítico a la Edad Media: 144-166. Valladolid: Glyphos Publicaciones.

Pereira, L. 1999. As cerâmicas 'Cogeces' de Castelo Velho, Freixo de Numão (Vila Nova de Foz Côa). Seu enquadramento peninsular. Unpublished Master's dissertation. University of Porto.

Pereira, T., Sampaio, H.A., Bettencourt, A.M.S., CunhaRibeiro, J.P. and Brito, M. 2018. Práticas funerárias do Calcolítico e da Idade do Bronze da gruta da Lorga de Dine (Vinhais, Norte de Portugal): estudo antropológico. Férvedas 9: 59-66.

Pérez-Obiol, R., García-Codrón, J.C., Pèlachs, A., Pérez-Haase, A. and Soriano, J.M. 2016. Landscape dynamics and fire activity since $6740 \mathrm{cal}$ year BP in the Cantabrian region (La Molina peat bog, Puente Viesgo, Spain). Quaternary Science Reviews 135: 65-78.

Pina, L. 1928. A Penha eneolítica. Revista de Guimarães 38(3-4): 135-138.

Prieto Martínez, M.P. 1999. Caracterización del estilo cerâmico de la Edad del Bronce en Galicia: cerâmica campaniforme y cerâmica no decorada. Complutum 10: 71-90.

Prieto Martínez, M.P. 2011. Unity and circulation: what underlies the homogeneity of Galician bell beaker ceramic style?, in P. Prieto Martínez and L. Salanova (eds) Las comunidades campaniformes en Galicia. Cambios sociales en el III y II milenios BC en el NW de la Península Ibérica: 209-249. Pontevedra: Diputación de Pontevedra.

Prieto Martínez, M. and Gil Agra, D. 2011. Fraga do Zorro: fosas y cacharros. Innovaciones en la alfarería de la necropolis, in P. Prieto Martínez and L. Salanova (eds) Las comunidades campaniformes en Galicia. Cambios sociales en el III y II milenios BC en el NW de la Península Ibérica. 139-147. Pontevedra: Diputación de Pontevedra.

Prieto Martínez, M.P., Martínez Cortizas, A., Lantes Suárez, O. and. Gil Agra, D. 2009. Estudio de la cerámica del yacimiento de fosas de Fraga do Zorro. Revista Aquae Flaviae 41: 107-121.

Ramil Rego, P. 1993. Evolución climática e historia de la vegetación durante el Pleistoceno Superior y el Holoceno en las regiones montañosas del Noroeste Ibérico, in P. Alberti, L. Guitián and P. Ramil Rego (eds) La evolución del paisaje en las montañas del entorno de los Caminos Jacobeos: 25-60. Santiago de Compostela: Xunta da Galicia.

Ramil Rego, P. and Aira Rodriguez, M.J. 1993. A palaeocarpological study of Neolithic and Bronze Age levels of the Buraco da Pala rock-shelter (Bragança, Portugal). Vegetation History and Archaeobotany 2(3): 163-172.

Reimer, P.J., Bard, E., Bayliss, A., Beck, J.W., Blackwell, P.G., Bronk Ramsey, C., Grootes, P.M., Guilderson, T.P., Haflidason, H., Hadjas, I., Hatt, C., Heaton, T.J., Hoffmann, D.L., Hogg, A.G., Hughen, K.A., Kaiser, K.F., Kromer, B., Manning, S.W., Niu, M., Reimer, R.W., Richard, D.A., Scott, E.M., Southon, J.R., Staff, R.A., Turney, C.S.M. and Van Der Plicht, J. 2013. IntCall3 and Marine13 Radiocarbon Age Calibration Curves 0-50,000 Years cal. BP. Radiocarbon 55(4): 1869-1887.

Rimbu, N., Lohmann, G., Kim, J.-H., Arz, H.W. and Schneider, R. 2003. Arctic/North Atlantic Oscillation signature in Holocene sea surface temperature trends as obtained from alkenone data. Geophysical Research Letters 30(6): 1280-1283.

Rivas-Martínez, S., Penas, A., Díaz González, T.E., Cantó, P., del Río, S., Costa, J.C., Herrero, L. and Molero, J. 2017. Biogeographic units of the Iberian Peninsula and Balearic Islands to district level. A concise synopsis, in J. Loidi (ed.) Vegetation of the Iberian Peninsula, vol. 12: 29-80. Springer.

Rodríguez Casal, A.A. 1990. O Megalitismo. A primeira arquitectura monumental de Galicia. Biblioteca de Divulgación 4. Santiago de Compostela:Universidade Santiago de Compostela.

Rodríguez Rellán, C., Vázquez Martínez, A. and Fábregas Valcarce, R. 2018. Cifras e imágenes: una aproximación cuantitativa a los petroglifos Gallegos/Figures and images: a quantitative approach to the petroglyphs of Galicia. Trabajos de Prehistoria 75(1): 109-127.

Ruiz-Gálvez Priego, M. 1979. El Bronce Antiguo en la fachada atlántica peninsular: Un ensayo de periodización. Trabajos de Prehistoria 36: 151-172.

Ruiz-Gálvez Priego, M. 1987. Bronce Atlántico y Cultura del Bronce Atlántico en la Península Ibérica. Trabajos de Prehistoria 44: 251-264. 
Sampaio, H.A. 2014. A Idade do Bronze na Bacia do Ave (Noroeste de Portugal). Unpublished $\mathrm{PhD}$ thesis, University of Minho.

Sampaio, H.A. and Bettencourt, A.M.S. 2018. Vale Ferreiro (Fafe). Memória de um Lugar da Idade do Bronze do Noroeste Português. Braga: Lab2PT.

Sanches, M.J. 1992. Pré-história Recente no Planalto Mirandês. Monografias Arqueológicas 3. Porto: GEAP.

Sanches M.J. 1994. Laje de Vale de Juncal - Mirandela, in Atas do Seminário Megalitismo no Centro de Portugal, Mangualde, Novembro de 1992: 395-414. Estudos Préhistóricos 2. Viseu: CCEPBA.

Sanches M.J. 1995. Alabardas de tipo Carrapatas, in S.O. Jorge (ed.) A Idade do Bronze em Portugal. Discursos de Poder: 29-30. Lisboa: Instituto Português de Museus.

Sanches M.J. 1997. Pré-história Recente de Trás-os-Montes e Alto Douro. Porto: SPAE.

Sanches M.J. 2000-2001. O Crasto de Palheiros (Murça): do Calcolítico à Idade do Ferro. Portugália 21-22: 5-40.

Sanches, M.J. 2008. O Crasto de Pallheiros (Fragada do Crasto), Murça Portugal. Murça: Câmara Municipal.

Sanches, M.J. 2011. As estelas antropomórficas de Picote - Miranda do Douro (Trás-os-Montes), in R. Vilaça (ed.) Estelas e estátuas-menires: da Pré à Proto-História: 143-174. Sabugal: CEAUCP.

Sanches, M.J., Morais, P.R. and Teixeira, J.C. 2016. Escarpas rochosas e pinturas na Serra de Passos/Sta. Comba (Nordeste de Portugal), in M.J. Sanches and D. Cruz (eds) Actas da II Mesa Redonda Artes Rupestres da Pré-história e da Proto-história (Porto, Nov. 2011): 71117. Estudos Pré-históricos 18. Viseu: CCEPBA.

Sanches, M., Nunes, S. and Pinto, D. 2007. Trás-os-Montes (Norte de Portugal) - As gentes e os ecossitemas, do Neolítico à Idade do Ferro. A Concepção das paisagens e dos espaços na Arqueologia da Península Ibérica, in S.O. Jorge, A.M.S. Bettencourt and I. Figueiral (eds) A concepção das paisagens e dos espaços na Arqueologia da Península Ibérica. Actas do IV Congresso de Arqueologia Peninsular: 189-206. Faro: Centro de Estudos de Património, Departamento de História, Arqueologia e Património, Faculdade de Ciências Humanas e Sociais, Universidade do Algarve.

Santos-Estévez, M., Bettencourt, A.M.S., Sampaio, H.A., Brochado, C. and Ferreira, G. 2017. Shape and meaning: engraved weapons as materialisations of the Calcolithic/Early Bronze Age cosmogony in north-west Iberia, in A.M.S. Bettencourt, M. Santos-Estevez, H.A. Sampaio and D. Cardoso (eds) Recorded Places, Experienced Places. The Holocene Rock Art of the Iberian Atlantic Northwest: 151-165. British Archaeological Reports International Series 2878. Oxford: BAR Publishing.

Santos Júnior, J.R. 1963. As gravuras litotrípticas de Ridevides (Vilariça). Trabalhos de Antropologia e Etnologia 19(2): 111-144.
Schubart, H. 1973. Las alabardas tipo Montejicar, in Estudios dedicados al Prof. L. Pericot: 247-269. Barcelona: Univ. de Barcelona.

Senna-Martínez, J.C. 2017. Aspectos e problemas das origens e desenvolvimento da metalurgia do bronze na fachada atlântica península. Estudos Arqueológicos de Oeiras 15: 119-134.

Silva, A., Figueiredo, S.S., Neves, D. and Xavier, P. 2018. Sinais gravados da Idade do Bronze em Trás-osMontes Oriental: Rocha 11 de Vale de Figueira, in N. Hernández Gutiérrez, J. Larrazabal Galarza and R. Portero Hernández (eds) Arqueología en el valle del Duero. Del Paleolítico a la Edad Media: 167-180. Valladolid: Glyphos Publicaciones.

Silva, E.J.L. (2003). Novos dados sobre o Megalitismo do Norte de Portugal, in V.S. Gonçalves (ed.) Muita gente, poucas antas? Origens, espaços e contextos do Megalitismo. Actas do II Colóquio Internacional sobre Megalitismo: 269-279. Trabalhos de Arqueologia 25. Lisboa: Instituto Português de Arqueologia.

Soares, J.2016. Social complexity in the third millennium cal BC in southern Portugal, in J. Soares (ed.) Social complexity in a long-term perspective: 77-114. Setúbal Arqueológica 16. Setúbal: MAEDS.

Soares, J. 2020. Searching for the turning point to Bronze Age Societies in Southern Portugal: topics for a debate, in S.S. Lopes and S. Gomes (eds) Between the 3rd to the 2nd millennia BC: a tipping point? London: Archaeopress.

Sobrino, R. 1935. Corpus Petrogliforum Gallaecia. Santiago de Compostela: Seminario de Estudos Galegos.

Sousa, O. 1996. Estatuária antropomórfica Pré e Protohistórica do Norte de Portugal. Unpublished Master's dissertation, University of Porto.

Sousa, O. 1997. A estação arqueológica do Cabeço da Mina, Vila Flor. Notícia preliminar, Vila Real. Revista de Estudos Transmontanos e Durienses 7: 185-197.

Suárez Otero, J. 1991. Pieces of prehistoric jewellery in the Northwest of the Iberian Peninsula, in Galicia no Tempo/Galicia Trough Time: 136-143. Santiago de Compostela:Xunta de Galicia, Conselleria de Cultura e Xuventude.

Suárez Otero, J. 2011. Del campaniforme cordado AOC en el Noroeste Hispánico. Un extrãno e inesperado invitado, in M. Pilar Prieto Martínez and L. Salanova (eds) Las comunidades campaniformes en Galicia. Cambios sociales en el III y II milenios BC en el NW de la Península Ibérica: 259-265. Pontevedra: Diputación de Pontevedra.

Tabarés, M. and S. Baqueiro 2005. Estudo da cultura material do xacemento Montenegro, in F. CriadoBoado and E. Cabrejas Domínguez (eds) Obras públicas e patrimonio: estudo arqueolóxico do Corredor do Morrazo: 117-119. TAPA 35. Santiago de Compostela: Instituto de Estudios Gallegos Padre Sarmiento, Consejo Superior de Investigaciones Científicas. 
Taylor, J. 1970. Lunulae reconsidered. Proceedings of the Prehistory Society 36: 38-81.

Taylor, J. 1980. Bronze Age gold work of the British Isles. Cambridge: Cambridge University Press.

Teira Mayolini, L.C. and Ontañón Peredo, R. 2000 b. Revision de los grabados rupestres del Collado de Sejos (Polaciones), in R. Ontafion Peredo (ed.) Actuaciones arqueológicas en Cantabria: 1984-1999: 285288. Santander: Gobierno de Cantabria, Consejería de Cultura, Turismo y Deporte.

Teixeira, J. 2019. Os povoados da Pedreira e Regadas no contexto da Pré-história Recente do vale do Tua. As decorações dos recipientes cerâmicos enquanto modos de expressão identitária e de interação social. Unpublished Master's dissertation, University of Porto.

Tereso, J.P., Bettencourt, A.M.S., Ramil Rego, P., Teira Brión, A., López-Dóriga, I., Lima, A. and Silva, R.A. 2016. Agriculture in NW Iberia during the Bronze Age: a review of archaeobotanical data. Journal of Archaeological Sciences Reports 10: 44-58.

Vale, A.M.A. 2011. Modalidades de Produção de Espaços no Contexto de uma Colina Monumentalizada: o sítio pré-histórico de Castanheiro do Vento, em Vila Nova de Foz Côa. Unpublished PhD thesis, University of Porto.

Valente M.J. 2004. A fauna mamalógica do povoado do Fumo (Almendra, Vila Nova de Foz Coa). Revista Portuguesa de Arqueologia 7(1): 221-225.

Valera, A.C. 2007. Dinâmicas locais de identidade: estruturação de um espaço de tradição no $3^{\circ}$ milenio AC (Fornos de Algodres, Guarda). Braga: Município de Fornos de Algodres.

Valera, A.C. 2015. Social change in the late 3rd millennium BC in Portugal: The twilight of enclosures, in H. Meller, R. Risch, R. Jung and W. Arz (eds) $2200 \mathrm{BC}$ - A climatic breakdown as a cause for the collapse of the old world? 7th Archaeological Conference of Central Germany in Halle (Saale): 409-427. Tagungen des Landesmuseums für Vorgeschichte Halle. 13.12. Halle: Landesmuseum für Vorgeschichte Halle (Saale).

Valera, A.C. 2019. Landscapes of complexity in Southern Portugal during the 4th and 3rd millennia BC, in J. Müller, M. Hintz and M. Wunderlich (eds) Megaliths, Societies, Landscapes. Early monumentality and social differentiation in Neolithic Europe/Frühe monumentalität und soziale differenzierung, vol. 3: 1039-1054. Bonn: Verlag Dr. Rudolf Habelt GmbH.

Valera, A.C. and Rebuge, J. 2008. Datação de B-OSL para o fosso 1 do sítio Calcolítico do Lugar da Forca (Maia). Apontamentos de Arqueologia e Património 1: 11-12.

Van Schoor, M.L.O. 2003. Arqueometalurgia do Calcolítico e do Bronze Inicial no Norte de Portugal, in J.F. Manzano and J.I. Herrán Martínez (eds) Mineros y fundidores en el inicio de la Edad de los Metales: 82-98. León: Caja Madrid.

Varela, J.M. 2000. As cerâmicas do Bronze Inicial e Médio de Castelo Velho de Freixo de Numão(Vila Nova de Foz Côa). Tradição e inovação na transição do III ${ }^{\circ}$ para o II ${ }^{\circ}$ milénio AC (2 vols). Unpublished Master's dissertation, University of Porto.

Vaquero Lastres, J. 1995b.Túmulos tardíos en el NW. RB1: estruturas, in Actas del XXII Congreso Nacional de Arqueologia (Vigo, 1993), vol. 1: 405-410.Vigo: Instituto de Estudos Viguenses.

Vázquez Liz, P. and Prieto Martínez, P. 2016. El yacimiento de A Devesa de Abaixo (Pontevedra): muerte y tradición en la Prehistoria Reciente del Noroeste de la Península Iberica. Quadernos de Estudios Gallegos 63(129): 13-64.

Vázquez Martínez, A. 2015. Los petroglifos galaicos: una revisión sobre la distribuición especial, in $\mathrm{H}$. Collado Giraldo and J.J. García Arranz (eds) Symbols in the Landscape: Rock art and its context. XIX International Rock Art (IFRAO) Conference 2015: 841-846. ARKEOS 37. Tomar: IPT.

Vázquez Varela, J.M. 1980a. Enterramientos en cistade la Edad del Bronce en Galicia. Pontevedra 0: 23-40.

Vieira, A. 2015. Contributo para o Estudo dos Vestígios Arqueológicos do VI ao I milénios AC. Paisagens e Memórias na Bacia Hidrográfica do Douro. Unpublished PhD dissertation, University of Porto.

Vilas Boas, L. 2014. Vale de Chão 1, Braga. Um tumulus da Idade do Bronze no Noroeste português. Estudos do Quaternário 10: 15-23.

Wanner, H., Beer, J., Buetikofer, J., Crowley, T.J., Cubasch, U., Flückiger, J., Goosse, H., Grosjean, M., Joos, F., Kaplan, J.O., Küttel, M., Müller, S.A., Prentice, I.C., Solomina, O., Stocker, T.F., Tarasov, P., Wagner, M., Widmann, M. 2008. Mid-to Late Holocene climate change: an overview. Quaternary Science Reviews 27(19-20): 1791-1828. 


\title{
Chapter 3
}

\section{On Identity and Otherness \\ Reshaping the Dynamics of Late Prehistoric Art Traditions in Northern Portugal}

\author{
Lara Bacelar Alves \\ CEAACP - University of Coimbra \\ lara.b.alves@uc.pt
}

\begin{abstract}
As it is more often said than done, the challenge to look at what is exposed as a core issue may be more accurately addressed if we approach it from the margins. This premise is at the genesis of studies leading to the reconfiguration of the dynamics of Late Prehistoric art traditions in north-western Iberia and also of the hermeneutics disclosed in this chapter. But the need to attend to this procedure is also implicit in the research questions that inspired this volume, for the focus on evidence for social and cultural change in the transit from the 3rd to the 2nd millennium BC, implies a vigorous stretch of the temporal, spatial and conceptual boundaries as a means to look at the historical processes developing millennia before and after the transition. This chapter addresses the dialogue, affiliations and segregation processes apparent in the relationship between carvings and paintings in natural rock formations and decorated megalithic tombs, in the long-term and on a supra-regional scale, in order to re-think the socio-cultural processes underlying the emergence, span and abandonment of the major European rock art traditions that reached northern and central Portugal.
\end{abstract}

Keywords: Prehistoric Iberia, affiliations, segregation, rock art, megalithic art.

We don't see things as they are, 'We see them as we are

(Anais Nin, 1961, 'Seduction of the Minotaur', inspired from the Talmudic tractate, Berakhot) ...I am more interested in understanding how we can be sure of our knowledge rather than masking that knowledge with the veil of a Grand Theory.Bruno David

\section{Introduction}

It shall to be assumed at the outset that there are as many explanations for the dynamics of Late Prehistoric rock art traditions in Iberia as there are proposals for their chronological boundaries. And there have been many over the years. It is a story that has been told in a number of different ways, with a number of different 'endings', and implications for our understanding of the social and cultural contexts in which they were embedded. This is as such because our object of research is a low temporal resolution phenomenon, which Bailey describes as fragmentary, insufficiently dated and biased in nature (2005). Nevertheless, invoking G. Bailey's optimistic views, the study of low temporal resolution phenomenon 'may be turned to advantage to create a different conception of human history' (2005: 269) if appropriate methodological tools are applied.

The reality is that the knowledge produced in rock art studies is still seen as marginal, and the ways in which it is constructed are mostly self-contained. Methodology still tends to follow an hierarchical model, starting with the survey of an individual site that is then put into the context of a particular stylistic assemblage at a confined regional scale. Subsequently, the chronology of depictions and their makers is matched to the widely accepted chrono-typological framework and related with the modes of being of that particular period, conventionalised by mainstream archaeology. On the other side of the mirror, we very often see rock art serving as a kind of decorative device in handbooks on prehistory, and, with few exceptions, with the uncritical acceptance of chronological proposals put forward by highly ranked specialists, notwithstanding the fragility of the arguments that supported many of them. Lack of critique allied to what Shanks and Tilley (1987) called the 'comfort of the method', perpetuated this mutually trustworthy and reassuring relationship between rock art specialists and mainstream scholars.

As a result of this state of affairs, the question of what is the role of rock art research in terms of understanding the socio-cultural dynamics of human populations in the past still leaves specialists uncertain as to a straightforward answer. And, reversing the actors, we 
should seriously think about what kind of expectations prehistoric archaeologists have from rock art studies and how are they used in the process of thinking and writing on past societies.

The interpretative proposal exposed in this contribution results from an ongoing investigation that began in 1997, although only later provided with anatomic structure (Alves 2003). Inspired by the flow of new ideas introduced by 'Interpretative Archaeology' being explored in British archaeology in the mid 1990s, this work attempted to re-think the rock art of northwestern Iberia after pinpointing the issues that tended to be left outside the scope of conventional research. First, it was necessary to overcome the biases of studying rock art at local or regional level by widening the geographical scale of analysis to the whole of northwestern Iberia, which implied breaking across borders of various kinds: the political, administrative, but also the theoretical and historiographical borders between Portugal and Spain to the north and east, as well as the traditional division in archaeological research between the Atlantic coastal regions of northern Portugal and the hinterland. Second, the foundations of chronological proposals from different regions and academic backgrounds ought to be contrasted and reassessed. Third, the prevailing focus on the typological analysis of motifs should be complemented with insights on the materiality of the physical settings where the paintings and carvings were found - from the landscape to the natural architecture of the place - and the dialogue between humanly made designs and existing features in the rock formation (e.g. Alves 2002).

This work developed immediately after the breakthrough promoted by Richard Bradley's Rock art and the Prehistory of Atlantic Europe (1997), and attended particularly on his conviction that 'rock art research must contribute directly to Archaeology if it is to achieve anything of value'. The value is in actively contributing to the interpretation of the historical processes shaping the dynamics of past human societies, which implied vigorous adjustments to the ways rock art research was made and how it was perceived by mainstream archaeology. Yet, in conservative academic milieus locked in the quest for empirical evidence, aspects like the recognition that multiple pasts might have been produced within different (and even neighbouring) cultural, social and political contexts (Shanks and Tilley 1987) do not tend to be easily assimilated. Conversely, outside these academic circles, increasing attention is being given to the relationship between different European prehistoric art traditions (e.g. Bradley, 2020) and their underlying socio-cultural 'identities', which, as social realities, "can be shaped only by attending to a specific time and space and in opposition to others' (Domingo Sanz et al. 2009: 25).
Hence, this interpretative endeavour is perhaps better understood in the scope of an 'archaeology of social being', as proposed by Meskell and Preucel (2008), than one emanating from classical rock art research. In this perspective, social archaeology is to be considered at the junctions of temporality, spatiality and materiality; and temporality is 'ultimately grounded in how people articulate with both the linear and recursive elements of their lived experience', meaning that time is spatially inscribed in social space, as it is socially produced (Meskell and Preucel 2008: 9-10). Space is to be seen as constitutive of social structures and simultaneously created through the practices and processes inherent in the reproduction of social life. Materiality focuses on the social life of things, which is tightly linked with M. Hall's concept of archaeology as 'a study of the ways in which we express ourselves through the things we make and use, collect and discard, value or take for granted, and seek to be remembered by' (2001, cited in Meskell and Preucel 2008:3).

I shall start by introducing a critique to the scenario in the late 1990s/early 2000s on the symbolic ontologies of the Neolithic, which, in western Iberia, spans from the late 6th/early 5th millennia $\mathrm{BC}$ to the end of the 4th millennium $\mathrm{BC}$, and contrasting them with the dynamics of rock art in the 3rd and beginning of the 2nd millennia BC. The discussion will take into account the latest overviews on social and cultural change in this period concerning, in particular, burial practices and material culture, as an attempt to offer a contextual reading. This will be established around the concepts of 'time perspectivism' and the application of wide and dialectical scales of analysis to low resolution phenomena; on 'identity(ies)'; and historical processes regarding the adoption, resistance and rejection of innovations.

\section{The 'movement of signs' - rock art traditions of the 'old' world}

\section{The research questions}

At the dawn of the millennium, the scenario was that of two major European Late Prehistoric rock art traditions converging in northern Portugal:

- Schematic Art paintings were concentrated towards the east and dated from the regional Early Neolithic, i.e. from the late 6th/beginning of the 5th millennium $\mathrm{BC}$, to the end of the Copper Age/Early Bronze Age, in the late 3rd/ beginning of the 2 nd millennium $B C$.

- Atlantic Art carvings were found in western regions, and believed to have spanned from the late $3 r d$ to the early 2 nd millennium BC (Figure 1). 


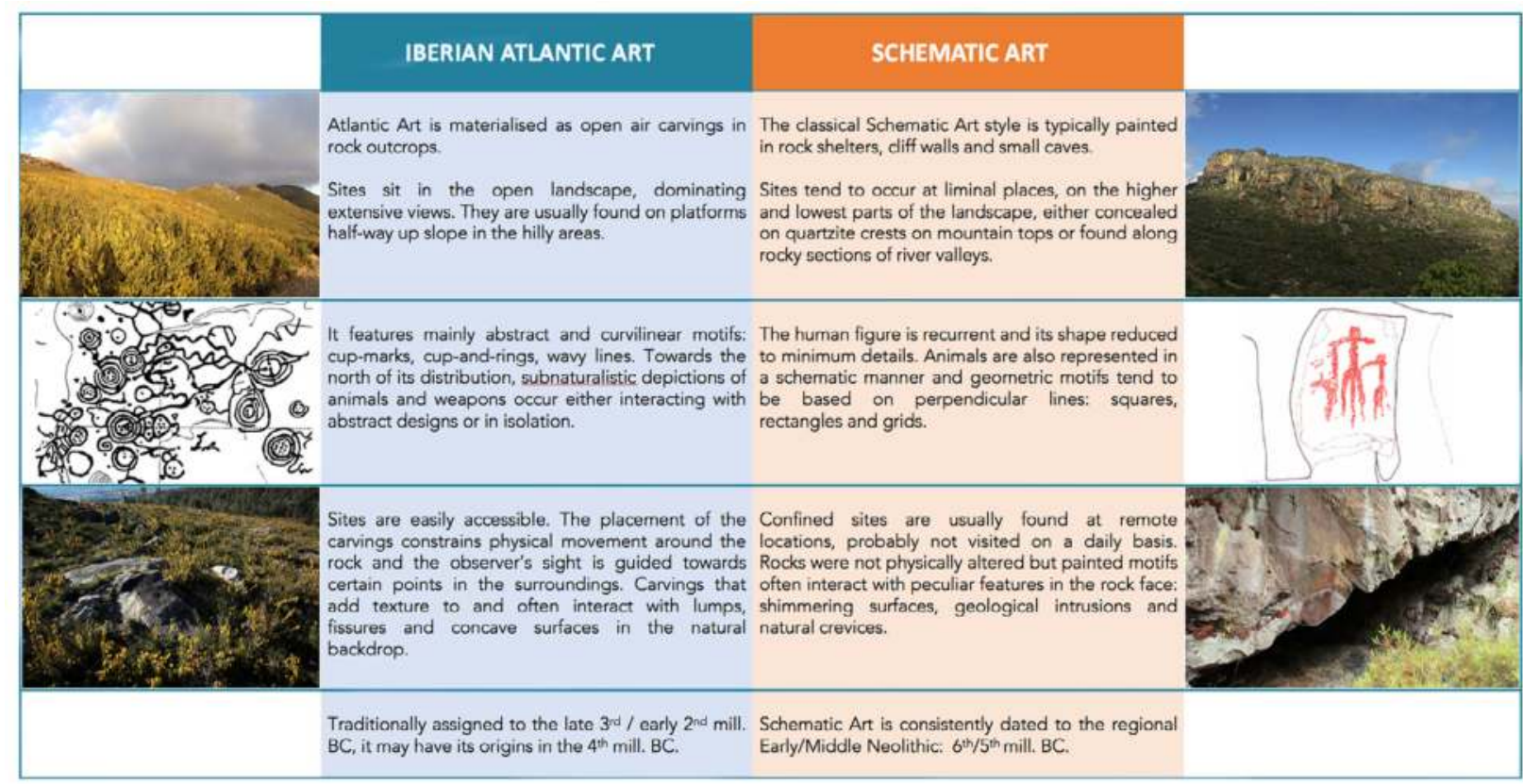

Figure 1 - The chief characteristics of the two Late Prehistoric rock art traditions converging in northwestern Iberia.

Because it was unquestioned that the expansion of both traditions into northern Portugal had been subsequent in time, they were treated as independent realities and the fact that they might have coexisted shortly before coming out of use was highlighted by few (Bradley and Fábregas 1998). However, there were a couple of simple, yet crucial, questions that remained to be asked: why did Schematic Art not expand towards the north-west of Portugal from the 5th to the 3rd millennia BC, even though carvings and paintings in megalithic tombs spanned across both regions? Why were north-western Iberian landscapes entirely devoid of rock art during the entire course of the Neolithic?

These issues were then summed up in the following research questions:

- To what extent has historiography been forcing research to follow paradigms based upon insufficiently tested evidence regarding the spatial, temporal and conceptual frames of prehistoric art?

- If two major prehistoric art traditions occur in the north-west of Iberia, what are their real spatial settings and how do they merge towards the boundaries?

- What are the implications of this convergence to the definition of their temporal span, the sociocultural contexts in which they were adopted, and the repercussions in other means of deploying symbolic imagery, namely megalithic art?

- To what extent does the study of the relationship between rock art and features of the natural world - from the landscape to the rock face help us to assess the social roles of prehistoric art, audiences and the contexts in which they were produced? (Alves 2003: 23).

\section{Finding ways of exploring new possibilities: the methodology}

The methodology employed to tackle these many questions implied breaking with the tendency to circumscribe rock art studies thematically, geographically, and/or chronologically by widening the scales of analysis and constantly adapting the lens from the detail to the wider picture. This dialectical approach was used as a means to seek diversity instead of regularities, to experiment alternative readings, or, in the words of Lopes and Gomes, 'to explore new possibilities of ordering difference' (2018: 3). ${ }^{1}$ Looking at changes and continuities in the long-term and across wider regions on issues such as material culture and the social uses of contrasting landscapes from east to west (Alves 2003; 2009a; 2009b) was, in some ways, an attempt to follow a symmetrical perspective.

At the foundations of this work was a critical review of the literature and detailed analysis of the archaeological evidence supporting chronological proposals for the origins of both rock art traditions. The structure was then built around the re-assessment of rock art sites in specific geomorphologic units, retrieving the focus on the imagery and thinking about how they connected with the natural properties of the backdrop and the

\footnotetext{
The present author's translation.
} 
surrounding landscape - aspects that were almost entirely overlooked at the time in Portuguese rock art studies. The goal was also to investigate the most essential and permanent elements across different regions that would have influenced the ways of life in the past, and, inevitably, the dynamics of social, cultural and ideological superstructures. As we shall see, this was later developed by adopting concepts from biogeography as a tool for interdisciplinary analysis (e.g. Alves 2012; Alves and Comendador 2017).

The study extended to an investigation into the dialogue between different prehistoric art traditions including megalithic art, leading to the scrutiny of their contexts, origins and temporal span as well as related processes of transmission, adoption or rejection, change and dilution (Alves 2003). It necessarily considered the presence of shared or mutually exclusive identities at regional and supra-regional scales. Given that the aim of this work was to find alternative readings and strategies of systematising data, there was a conscious refusal to propose rigid chrono-typological frameworks, and instead following a fluid narrative, which seemed more appropriate to look beyond what had been seen.

\section{The 'movement of signs': intersections, connections and resistance}

Investigating the dialogue between contrasting rock art traditions meant not only breaking through administrative borders, ${ }^{2}$ expanding temporal boundaries, replacing the focus on typological and technical aspects for a focus on stylistic conventions, dynamics and movement, but also meant to draw on previous research, updating, expanding, or consolidating some proposals, as well as re-assessing others.

As known, Atlantic Art carvings concentrate along the coastal amphitheatre confined by a chain of mountains that extends southwards from Galicia to centralnorthern Portugal down to the Vouga basin, and echo supra-regional affinities with the rock art of Great Britain and Ireland (e.g. Bradley 1997; Valdez-Tullett 2019). To the east we find Schematic Art paintings, whose main distribution spans across eastern, central and southern parts of Iberia, and finds its closer counterparts in the Western Mediterranean. The two traditions are mutually exclusive in space, each sitting on either side of the central mountain range. It is interesting to note that, in northern Portugal, the transition area between the two traditions runs precisely along the line that separates the Atlantic and

\footnotetext{
2 A.M. Baptista's interpretative proposal of rock art in Portugal (1983-1984) had already attended to the setting of different 'rock art cycles' in contrasting natural regions, yet it has not been updated or developed since.
}

Mediterranean biogeographical areas of Europe (Alves 2014: Fig. 1; Alves and Comendador 2017). Nevertheless, they were supposed to be subsequent in time.

From the early 1990s, the origins of Atlantic Art were drawn back from the Middle Bronze Age to the Copper Age (Jorge 1991; Peña and Rey 1993) (Figure 2). Proponents emphasised the occurrence of halberds, daggers and idols carved alongside the classical curvilinear motifs, arguing that this tradition was to be associated with the symbolic marking of new territories, where the power and prestige of emerging elites were negotiated (Bradley 1997; Jorge 1999; Peña and Rey 2001). This was further supported by a study that attempted to show a spatial relationship between rock art sites, settlements and burials from the end of the $3 \mathrm{rd} /$ beginning of the 2nd millennium $B C$ in the Morrazo peninsula (Galicia) by Peña Santos and Rey García (1993). However, a thorough analysis of the information behind the dots plotted on the map demonstrated that the supporting evidence was utterly fragmentary, heterogeneous, and not entirely explicit, failing to show a systematic association between Atlantic Art and the selected archaeological sites (Alves 2003; 2014: 19-22). This is not to say that this tradition was not active by then, rather that this particular study did not show that the origins of Atlantic Art are to be assigned to that period. This paradigm was long lasting, for reasons that are more concerned with the internal dynamics of the academic fabric then with the solidness of its foundations. Moreover, if the advent of Atlantic Art marked the end of the 'old world', the social rise of the individual and emergence of warrior elites as argued, why did it not last beyond the beginning of the 2nd millennium $B C$, side by side with the reinforcement of the new social order and political institutions?

The presence of weapon carvings was clearly overemphasised, for it is the one element that allows relative dating. But looking at the statistics known at the time, they represented less then $5 \%$ of carved motifs in the province of Pontevedra (García Alén and Peña Santos 1980). Updated analysis pushes back the percentage to a mere $2 \%$, corresponding to 53 Galician sites displaying halberds and daggers, against $56.8 \%$ of rocks carved with circular designs, in a total of 1910 sites (Vásquez Martínez et al. 2016: 67). The limited occurrence of weapon carvings seemed to us better understood as episodic in a long duration cycle (Alves 2003; 2014: 21). But was this episode to be placed at the beginning or at the end of the Atlantic Art sequence?

If scrutiny into the core subject seemed unsuitable to provide clues as to the emergence of Atlantic Art, we set out to explore the margins, peripheral spaces, times, instruments of analysis, concepts and artistic expressions. As such, looking at the southernmost 


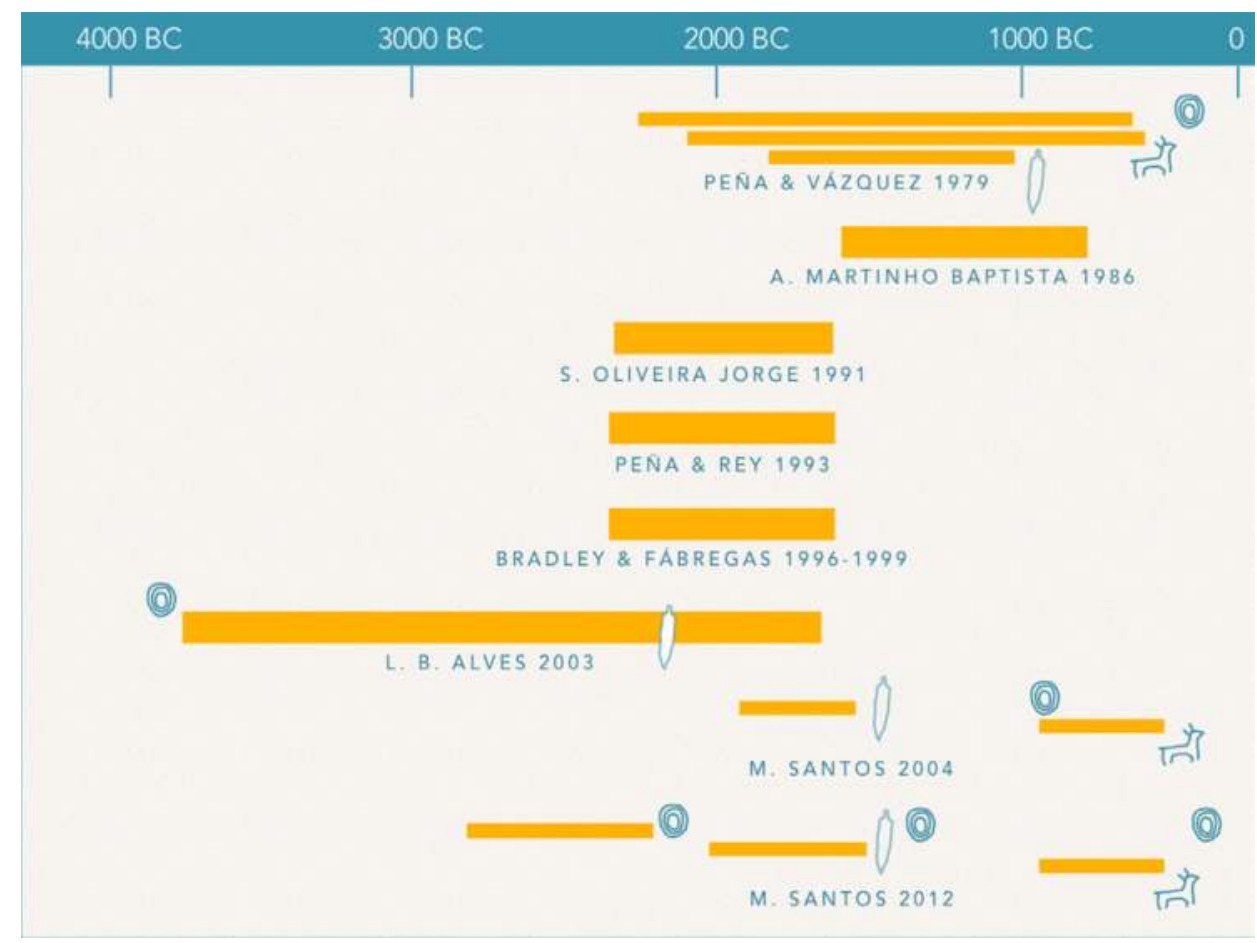

Figure 2 - The main chronological proposals for Iberian Atlantic Art.

area of distribution of Atlantic Art in Europe, along the Vouga river, which runs westwards, cutting across the central mountain range, we saw the number of carved rocks diminishing towards climatic areas characterised by lower annual levels of rainfall to the east (Alves 2003: Fig. 71). This evidence was investigated further by using analytical instruments provided by biogeography, a particularly interesting discipline for archaeology as it is based on the study of past and present relations between climate and the distribution of living beings on Earth (Aguiar 2008) (Figure 3). One of its goals is to establish typological hierarchical models of the territory based on the circumscription of ecological communities sharing climatic conditions and geological features which support species with similar life and adaptation strategies, known as biomes (Costa et al. 1998: 6; Spellerberg and Sawyer 1999: 2). The interest of this approach rests on the idea that biomes deeply influence economic strategies and the ways societies are structured. If adaptation to what the land has to offer is at some extent bound to human culture, it may be reasonable to argue that the features that characterise a particular biogeographical region are likely to shape the relationship between humans and the natural world (Alves and Reis 2017: 50). Long before Iberia's biogeographical units were defined, O. Ribeiro (1945), described two contrasting ways of life between eastern and western parts of northern Portugal, stressing that, towards the west, the landscape evokes Brittany or Ireland, as opposed to the arid hinterland which recalls the extreme south. Ribeiro asserted that the sense of belonging emanating from the earth was the birthplace of people's wisdom shaped by the communities' labour and experience (1945). Could it be the case that the establishment of different rock art traditions in different environments was related to 'two different ways of living' in north-west Iberia, as suggested by Bradley and Fábregas (1998: 306)? This is a question emerging from rock art studies but which is yet to be thoroughly addressed by mainstream archaeology.

The fact that painted Schematic Art did not expand towards the north-west can hardly be explained by the occurrence of physical obstacles, as the central mountain range is not insurmountable. Also, it is not related to the absence of the conventional geological formations where Schematic Art paintings tend to be found, for, towards the coast, occasional rock shelters containing rock art are found to be carved with Atlantic Art imagery (e.g. Fábregas and Rodriguéz 2012). Moreover, it cannot be explained by the lack of preservation of pigments in the more humid Atlantic environments, for there is much evidence of paintings in the chambers of megalithic tombs across Galicia (e.g. Carrera 2011).

In 2003 it was suggested that the geographical confinement of Schematic Art in the inland areas of Trás-os-Montes and Beira Alta could be explained by processes of social rejection of this tradition by communities with pre-existing and well-established symbolic structures living along the Atlantic façade 


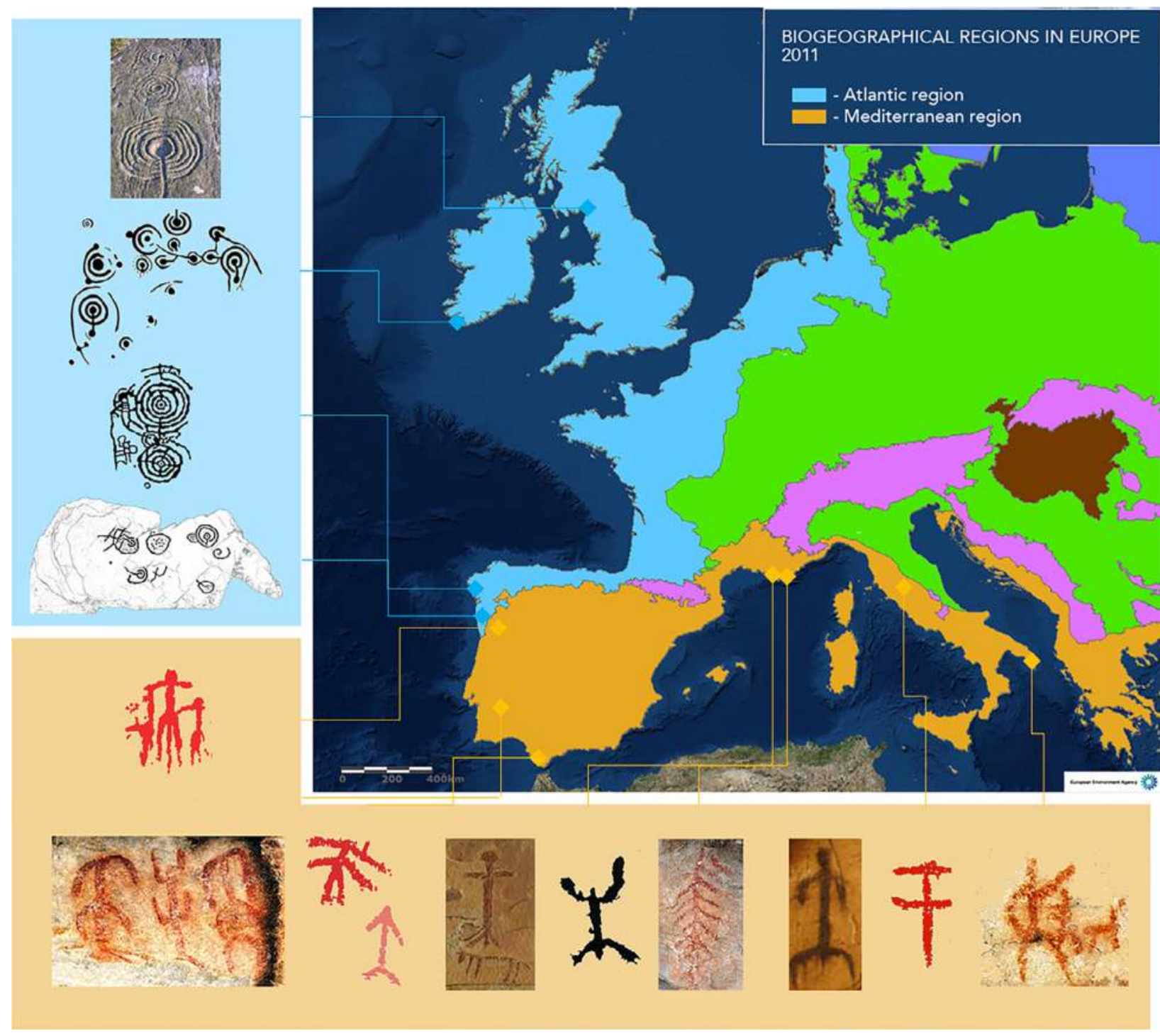

Figure 3 - Distribution of Late Prehistoric art traditions and the different styles of Megalithic Art in northern Portugal. The blue shade corresponds to the span of the Atlantic biogeographical region (after Costa et al. 1998).

(Alves 2003: 427). This statement ultimately suggests that questions of identity and otherness need to be addressed in greater detail, in association with issues underlying the dynamics of the processes of adoption and rejection of innovations, for the establishment of two different rock art traditions in distinct biogeographical regions may echo the presence of independent socio-cultural identities on either side of the central mountain range in the Neolithic (perhaps even in the early stages of this period).

Processes of resistance and rejection have not been widely explored in prehistoric archaeology, however, discussing the strategies through which societies coped with innovations, K. Kristiansen highlights the idea that 'innovations are resisted if they cannot be integrated within existing social and cosmological frameworks' (2005: 154). The author provides the example of the Baltic Ertebølle Culture, which resisted the expansion of agriculture for a whole millennium because there were no incentives to disrupt a stable socio-economic structure, or the long-term refusal of southern Scandinavian societies to adopt iron technology, as it meant disturbing the social and cosmological structures grounded on well-established networks related to the acquisition and uses of bronze (2005: 154).

In an attempt to investigate further aspects of diffusion and interaction, permeability and resistance, we looked for connections with measurable time in the evidence from other backdrops in which symbolic imagery was deployed in the Neolithic, namely megalithic art. Considering the swift appearance of monumental architecture in the late 5th/early 4 th millennium cal BC (Cruz 2001), we see, at the first glance, that architectural forms and techniques do not differ much across northern Portugal, but inside these 'humanly-built subterranean spaces', megalithic art seems to indicate 
otherwise. It is common knowledge that megalithic tombs have a ubiquitous presence to the west and south of the central mountain range, but are poorly represented in the north-east. However, here, and in the Viseu area, passage graves were dressed with a range of human and animal figures, as well as grids that are common to Schematic Art paintings in natural rock formations, (e.g. Baptista 1983-1984; Sanches 1997; Shee 1981). So, if the origins of Schematic Art predates (or is contemporary with) the emergence of monumental architecture, this implies that its design grammar and iconographic features were intrusive in the decoration of passage graves (Bueno and Balbin 1992). Also, the evidence that passage graves displaying Schematic Art imagery form a geographically confined and stylistic consistent assemblage, contrasting with megalithic art towards the west, was sufficiently striking to incite many specialists to consider the existence of more than one stylistic group in northern Portugal (Leisner 1934; López Cuevillas 1948; 1980; Shee 1981). These early works established differences more in terms of technical issues, such as paintings being prevalent in central and eastern regions and carvings dominating across the north-west, but also the presence/absence of specific types of figurative motifs, although both groups shared geometric patterns of surface decoration (e.g. Shee 1981).

By the mid 1990s, stimulated by the new developments in research after the discovery of preserved paintings in several Galician monuments, Bello Diéguez produced a thorough re-assessment of the megalithic art found along the north-western Atlantic façade of Iberia. The author suggested the existence of a distinctive style in this region, characterised by the presence of meanders invading the operational surfaces of orthostats, simple and concentric circles, semi-circles, U-shape motifs, zigzags, and by the scarcity of figurative motifs. He classified this style as the "North-western group of Megalithic Art' (1994), which was taken as complementary to E. Shee Twohig's 'group of Viseu', spanning to the south and east. ${ }^{3}$

\footnotetext{
${ }^{3}$ All studies on Iberian megalithic art that suggest the existence of regional stylistic groups have been discarded over the last two decades (e.g. Bueno and Balbín 2009: 87-88). This has to do not only with the scarcity of researchers devoted to this subject but also to the influence of representatives of a generation that grew up on a processual and evolutionist school of thought. Also in the study of monumental architecture from the 1970s onwards, inquiry methods tended to privilege typological and technical analysis of architectural features, favouring the establishment of an homogeneous picture of the phenomenon. The prevailing idea is the existence of common codes across the whole of Iberia, avoiding looking at what is different. The same happened with megalithic art. The early debate about paintings and carvings being mutually exclusive was totally transformed by the finding of paintings across Iberia, yet this argument prevails in the foreground for critics of the definition of regional sub-styles. None of the fundamental evidence put forward in challenging proposals, such as by Bello (1995), was accurately assessed by critics, but even so, any further questioning on diversity and stylistic variation was eliminated.
}

In fact, if we look at the scale of cemeteries along the Atlantic façade, arrangements are not generally entirely alike amongst tombs situated close together, as happens at Chã de Parada, Baião (Shee 1981), or Alto da Portela do Pau, Castro Laboreiro (Baptista 1997). However, there is a disturbing similarity in the decoration of pairs of monuments sitting hundreds of kilometres away from each other in north-western Portugal and Galicia, such as Chan de Castiñeiras (Marin, Galicia) and Alto da Portela do Pau 2 (Melgaço, Portugal), Tumba de Castellin (Navias, Astúrias), and mound 1 at Taco in the Vouga basin (Albergaria-a-Velha, Portugal) (Alves 2003: Fig. 110; 2009b: 175). Moreover, at much shorter distances, but in a west-east direction, the style of megalithic art formally changes (Figure 4). Also, it is pretty straightforward to notice that the distribution of Bello's 'north-west style of Megalithic Art' overlaps with the distribution of Atlantic Art, but also that this style, either painted or carved, is mostly curvilinear, geometric and abstract. Yet few of these curvilineargeometric motifs recall the classical designs from the repertoire of Atlantic Art, with the exceptional cases of the set of concentric circles carved at Mota Grande, mound 2 at Alto da Portela do Pau, or painted at Chã de Parada, and the coaxial arcs from Taco mound 1, reminders of megalithic art from Brittany and Ireland (Alves and Carvalho 2017).

Archaeologists tend to consider stylistic differences as indicators of chronological change, however if Atlantic Art designs only make sense in relation to the wider landscape and its features, as Bradley rightly showed (1997), we have to ask whether exactly the same motifs and conventions would have been suitable for use inside stone-built structures? For instance, Irish megalithic art shares some individual motifs with Atlantic Art, but the design grammar greatly differs between the two.

In addition, if it is consensual that Schematic Art is intrusive in megalithic art to the east of the central mountain range, it is because the types of motifs shared between the two - human figures and animals - obey strict conventions and are easy to identify, yet the truth is that only few types from the overall repertoire of Schematic Art were selected for painting in burial chambers. The typical sequences of bars or clusters of dots, widespread across Iberia in natural rock shelters, are virtually absent from passage graves.

We should note that styles are intentionally created to guaranty the maintenance of formal resemblance in time and space from generation to generation, since the intelligibility of forms is intrinsic to social interaction (Alves 2003). Styles with a long timespan that become the visible face of social and cultural 'identity' may be called 'traditions'. So, it is possible that the Atlantic and Schematic art traditions might have incorporated, or 


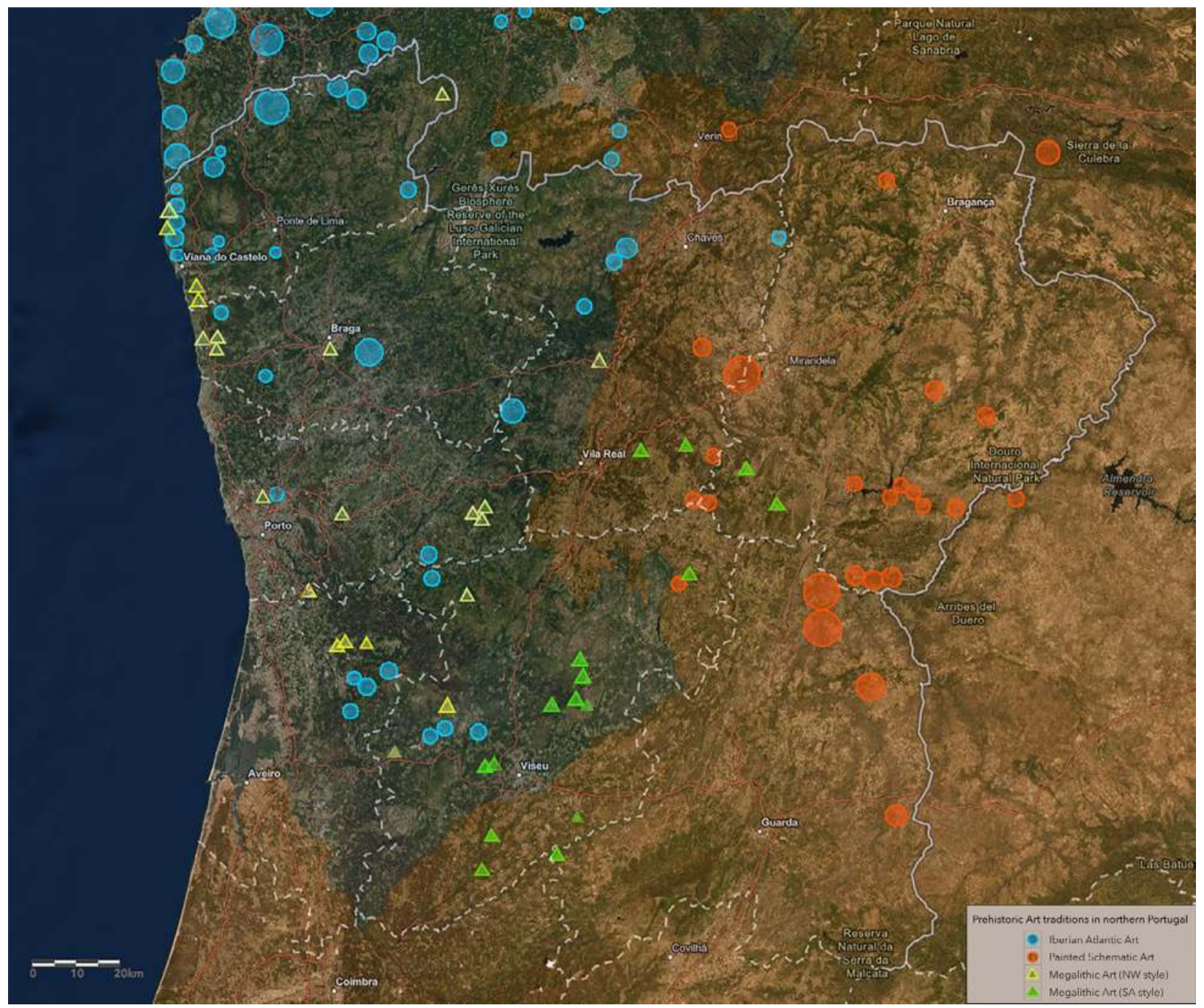

Figure 4 - Distribution of Atlantic Art and Schematic Art paintings across the Atlantic and Mediterranean biogeographical regions.

provided the origin for, particular styles meant to be displayed in megalithic tombs.

To sum up, this proposal brought to light a scenario that had not yet been firmly investigated in the study of Iberian prehistoric art: the possibility that Atlantic Art was already in use by the 4th millennium BC, overlapping with an essentially abstract-geometric style of megalithic art (Alves 2003). If so, we could be dealing in north-western Portugal and western Galicia with a wide system of representation composed of two partly coexisting styles: one that was meant to be exhibited in the open landscape and another conceived for the dead. If this was the case, they would be contemporary with Schematic Art paintings for at least the 4 th, and the whole of the 3rd millennium BC.

\section{Views from across the sea}

It is right to say that this interpretative structure is far from being grounded in large-scale empirical sources, but this has to do precisely with the nature of low resolution phenomena. This perspective alters what was widely accepted so far in regard to the dynamics of late prehistoric art, but still fails to explain the historical processes behind the presence of Atlantic Art in north-western Iberia, which implies thinking about the mechanisms behind the expansion of this tradition across Atlantic Europe - a delicate issue that modern archaeology has largely avoided. In his book on the subject, Bradley accepts the traditional Iberian short chronology and considers that contacts with the British Isles were to be explained in the context of long-distance interactions opened by the emergence of metalwork and bell beakers (1997). In this way, Bradley conformed both with MacWhite's thesis from the 1940s and with the conventional dating for Atlantic Art in the British Isles and Iberia (1997) (Fig. 2). At the time, it was still undisputed that Irish megalithic art predated the cycle of rock art. Yet, over the last decade, research has brought new insights into the chronology of prehistoric art in the British Isles. 
In Ireland, ground-breaking research around Loughcrew looked at the Atlantic Art sites known to be dotted around the conspicuous hills crowned by a vast assemblage of decorated passage graves. Fieldwork by the team led by E. Shee Twohig was able to increase substantially the number of rock art sites and identify a few cases of ancient quarrying of carved outcrops (2012). In this context, a reassessment of Loughcrew's megalithic art demonstrated that there were not only motifs from different styles in passage grave slabs but that they also showed highly differentiated degrees of weathering. One interesting aspect that came to light was the presence of circular images characteristic of open-air rock art amongst the most weathered motifs, which, added to the evidence for ancient quarrying at nearby rock art sites, reinforced the idea that previously carved panels were included in the building of these monuments (Twohig et al. 2012). As the pattern of weathering was quite significant, if compared with the fresh-looking engravings on other chamber slabs, open-air rock art would then most probably tomb construction (Figure 5). Despite the absence of modern excavations at Loughcrew, recent reviews of the radiocarbon dates from Irish passage graves brings their chronology back to an interval between 37753520 BC (95.4\% probability) (Cochrane and Jones 2018: 138). The use of Bayesian modelling for the programme of radiocarbon dating at Knowth shows that the main phase of use of the largest tomb and funerary activity lasted between 100 and 300 years in the period of 32002900 BC (Schulting et al. 2017: 378; Eogan and Cleary 2017). At Newgrange Site 1, the date range for the construction of the cairn is currently established at $c$. 3200-3000 BC (Schulting 2014).

Also, the hidden art at Newgrange, most probably originating from the reuse of previous building material, shows more similarities with open-air rock art then that visible in its inner recesses. This is only one of the arguments put forward in 1993 by S. Johnson to support a stylistic analysis that indicated that Irish rock art predated megalithic art - and not the opposite (Johnson 1993). Also, C. Waddington argues that Atlantic art not only precedes, but also outlives passage grave art in Ireland (2007).

Hence, the chronology of Irish passage graves matches the dating of their counterparts in north-western Iberia (e.g. Cruz 2001), and the origins of Atlantic Art in Ireland are now starting to be pulled back from the 3rd/2nd millennia BC (e.g. Waddel 2015: 168) to the 4th millennium $\mathrm{BC}$.

Across the Irish Sea, advances on the chronology of Atlantic Art in northern England and Scotland are grounded on archaeological excavations. At Hunterheugh Crag, an Early Bronze Age cist partly rested on top of a group of rocks decorated with
Atlantic Art dated, according to the excavators, to the Neolithic (Waddington et al. 2005). It was also attested that some of carved rocks in the vicinities were quarried and their fragments incorporated in the construction of the tumulus. There is also evidence that new motifs were roughly carved on the surfaces exposed by the extraction of blocks. This site thus reveals a terminus post quem for Atlantic Art in the Early Bronze Age, when this tradition is coming to and end in the region.

Further north, at Torbhlaren (Kilmartin, Scotland) excavations provided dates of the very beginning and mid 3rd millennium BC for activities around carved outcrops (Jones et al. 2011). In regard to the findings at other excavated sites in Great Britain, Cochrane and Jones highlight the presence of pitchstone, a volcanic glass found in Scotland known to have been worked from the Mesolithic to the Neolithic (2018: 138). Also, recently, an investigation into neolithic portable artefacts from Britain and Ireland decorated with motifs similar to those found in passage graves and open-air rock art, e.g. spirals and nested arcs, suggest that they can be dated to between $3500-3100$ cal. BC (Jones and Diaz-Guardamino 2019).

Similarly to Iberia, an earlier date for the emergence of Atlantic Art is still not consensual amongst British archaeologists (e.g. Sheridan 2012: 173). As far as the later moments of this tradition are concerned, it is interesting to note that weapon carvings are rare in the British Isles, apart from a few examples of Scottish rock art and stone-built monuments dated to the Early Bronze Age, clearly dominated by the representation of axes (virtually absent from Iberia), with the exceptional halberd engraved on a monolith from Ri Cruin cairn in Kilmartin (Needham and Cowie 2012), which nonetheless presents notable stylistic differences from those found in Iberia.

However challenging to establish, the limits of historical periods should refer to moments in which there are significant changes in the widest range of variants in the social sphere (Valera 2017: 36). Although the proposal that Atlantic Art was already in use by the 4th millennium BC is something still not widely acknowledged by mainstream archaeology, there is evidence to consider its latest stages within the framework of the socio-cultural shifts apparent in the transition from the 3 rd to the 2 nd millennium BC (e.g. Alves, 2014).

\section{Prehistoric art in northern Portugal in the transition from the 3 rd to the 2 nd millennium BC}

The discussion of the continuities and changes in the uses of Atlantic and Schematic Art traceable from the mid/late 3rd millennium BC should next be put against the ideological, social and cultural 

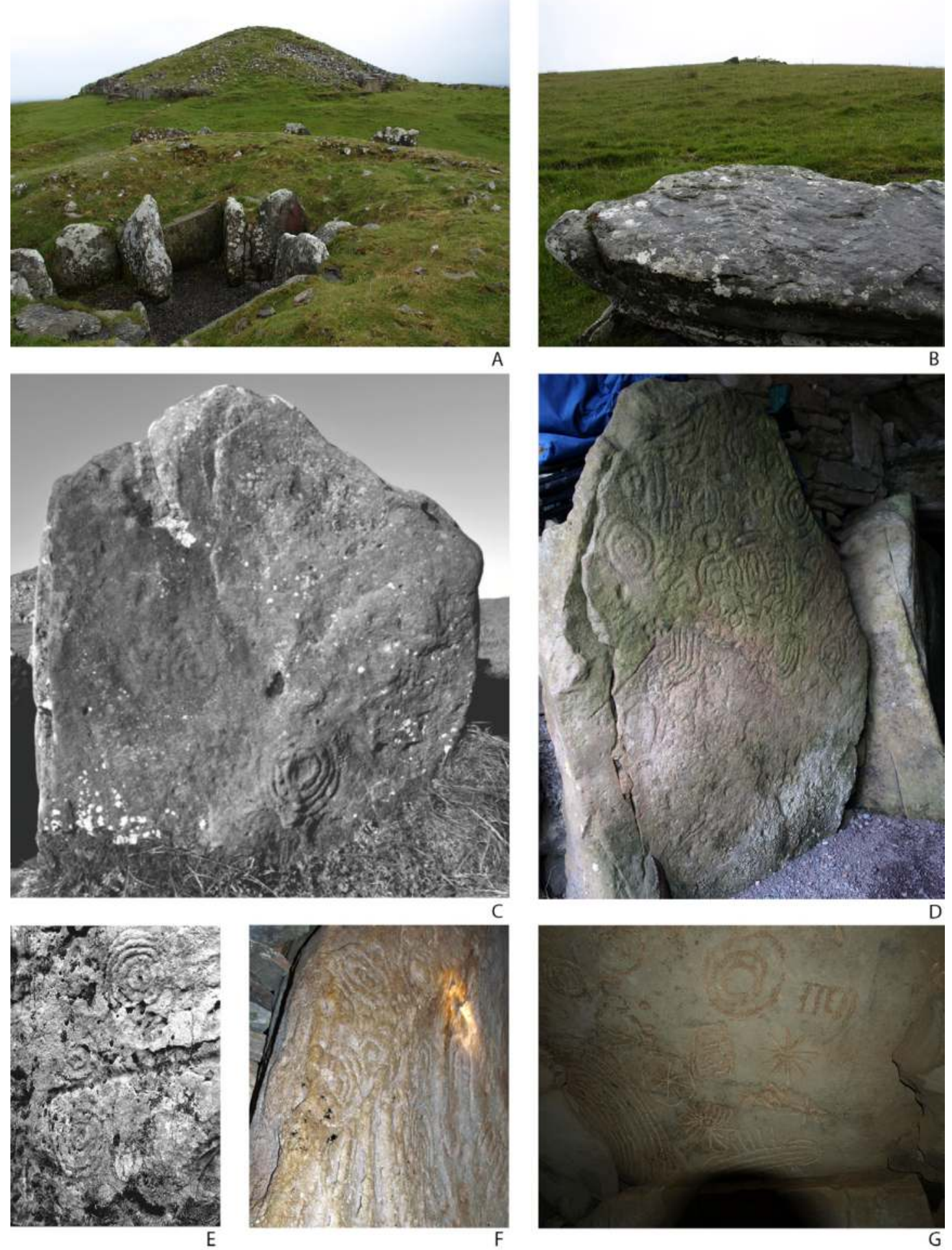

Figure 5 - Loughcrew, co. Meath (Ireland). A - The summit of Carnbane East hilltop with cairn T in the skyline (photo: L. B. Alves); B - the carved rock Corstown ME015-113 (Twohig, et al. 2010: 11) at Carnbane East, on the slope leading to the tombs (photo: L. B. Alves); C - on Cairn V, the orthostat C3 shows sets of motifs that are more typical of open-air rock art than of the Irish Passage Grave style, namely the rings surrounding a central cup-mark. There is visible a differentiated degree of weathering amongst the motifs. D - Ortosthat L2 - Cairn T exhibits a range of motifs similar to open-air rock art, like cup-and-rings, cup-marks, cup-mark clusters, different techniques of engraving and degree of weathering. E - The ortosthat C3 - Cairn H show severely weathered cupand-ring marks, fact which is better explained if the slab was incorporated in the tomb after the carvings were previously weathered in the open-air. F - Orthostat C15 - Cairn T Shows a severely weathered surface as well as some of the circular motifs. $G$ - In contrast, on the same tomb, a fresh rock surface on roofstone cell 2 exhibits the motifs typical of Irish Passage grave art, showing pecking marks in pristine conditions. 
structures characteristic of the 'old world', across the Mediterranean and Atlantic biogeographical areas of northern Portugal.

\section{The Mediterranean region}

The overview of late prehistory in northern Portugal by Susana Lopes and Ana Bettencourt looks at some of the dynamics between coastal areas of the north-west and the hinterland in comparative terms, pointing out the common adoption of innovations such as bell beakers, symbolic pottery decoration and copper artefacts in the 3rd millennium $\mathrm{BC}$, but also asymmetries in cultural evolution, which can be explained, in their words, by differential cultural ancestry (2017).

This is first and foremost visible in the burial record, with a decrease in tomb visibility and the emergence of new funerary practices (Lopes and Bettencourt 2017). One aspect that follows from the Neolithic is the presence of a larger number of burial sites in coastal regions if compared with the hinterland. Conversely, walled enclosures emergent in the east by the 3rd millennium $\mathrm{BC}$ are, according to current knowledge, uncommon towards the west. A further distinction can be pointed out regarding the contexts in which the bodies were disposed. Towards the west, there is a prevalent attachment to the 'old' ways and landscapes, as megalithic tombs are reused and new tumuli and cists are newly built in or around them (Cruz 2001). In contrast, the north-east shows a wider range of solutions - from stone cists at Vale da Cerva and Terraço das Laranjeiras and a few cave burials, to the deposition of human bones in the Castelo Velho walled enclosure (Lopes and Bettencourt 2017). The latter is so far unique, for it implies circulation of human remains, and, according to the authors, may be interpreted in terms of the maintenance of a neolithic symbolic ontology. If we put this suggestion against the evidence from one other domain of the symbolic - the rock art - we may find additional arguments to discuss the apparent invisibility of the burial record in the northeast in both the Neolithic and Copper Age.

We asked in 2003 why designs typical of Schematic Art on natural rock formations were adopted for decorating passage graves in central and north-eastern parts of Portugal. The presence of iconic elements from the Neolithic burial sphere, like schist plaques, at some Schematic Art sites of southern Iberia is widely known (e.g. Alves 2002); however, evidence that schematic human and animals figures were included in the decoration of stone-built monuments kept us thinking about what special meanings this imagery might have carried for its adoption within funerary contexts. Could it be that natural rock formations with Schematic Art paintings might also have been connected in any way to burial practices? Given the near invisibility of burials in north-east Portugal, other solutions might necessarily have been adopted for the disposal of the dead. It was then suggested that the private and often concealed places decorated with Schematic Art paintings might have been used for ephemeral burial practices, implying the manipulation, circulation and open-air deposition of human bones as ossuaries (Alves 2003; 2009a). Yet, because the majority of painted sites are bare rock, this type of evidence is obviously difficult to grasp. Notwithstanding, it is interesting to note that the Arquinha da Moura passage grave (Tondela, Viseu), which shows schematic animal and human figures painted in red, was actually used as an ossuary (Cunha, 1995).

It is consensual that Schematic Art in natural rock formations precedes passage grave building and its advent in north-western Iberia dates from the Early Neolithic. Yet, according to S. Monteiro-Rodrigues, pottery may have been introduced in the late 6th millennium BC; evidence for domesticated animals dates to the mid/late 5th millennium $\mathrm{BC}$; and domesticated plants to the early 4 th millennium $\mathrm{BC}$ (2011). Providing this picture, and given that the advent of megalithic tombs matches the adoption of the first domesticates, to which of these episodes should the emergence of Schematic Art be related?

Excavations carried out in painted rock shelters do not answer this question but provide some hints as to the periods in which they were in use. At Fraga d'Aia (Jorge et al. 1988) and Lapas Cabreiras (Reis et al. 2017) there is evidence for Early Neolithic pottery, attested by a fragment of boquique ware at the latter site ${ }^{4}$ and radiocarbon dates from hearths at the former. Both sites revealed material from the 3rd millennium BC, as well as at Ribeirinha, located in the vicinities of a settlement with Copper Age occupation (Reis et al. 2017). Just across the border, in Zamora (Spain), El Pedroso sits down slope from a Copper Age hilltop site and encloses a range of schematic imagery that, despite having been recut, are likely to have a prehistoric origin (Alves et al. 2013). Here, excavations revealed limited evidence of neolithic activities, although most artefacts and associated structures are assigned to the late $3 \mathrm{rd} /$ beginning of the 2nd millennium BC. The presence of a Palmela point suggests that the cave might have been used as a burial site in this period.

In fact, the proximity between some painted rock shelters and hilltop areas with surface finds dated to the Copper Age, worked as an indicator that these sites were still in use by the $3 \mathrm{rd}$ millennium BC (e.g. Sanches 1997). However, there are some signs of disruption of the ancient ideological structure. The cists of Vale da

\footnotetext{
${ }^{4}$ This is a surface find located in the transition from the soil and the bedrock just below the painted surface.
} 
Cerva, dated to the beginning of the millennium, are surrounded by upright surfaces displaying carvings of schematic human figures (Baptista 1983; Cruz 2001: 262). Could it be that the advent of new forms of burial took Schematic Art away from their traditionally more concealed locations and became more accessible as open-air carvings? (Alves, 2003)

At the same time, the appearance of statue-menhirs of Mediterranean style, and the creation of new settings where they were displayed, like Cabeço da Mina (e.g. Lopes and Bettencourt 2017) mark the adoption of innovations in one of the most stable domains of social life: the symbolic. These new sculptures representing individuals, either real or imaginary, were certainly related with the emergence of new spheres of power and cosmological settings. If we consider them to be the new canon, then the maintenance of use of old Schematic Art sites until the early stages of the 2nd millennium $B C$ could be explained as a process of resistance by certain spheres of society marginal to the new cultural and institutional cores, or, in other words, by groups within the society who were conservative in terms of ancient values and cosmologies. The presence of asymmetric rhythms in the acceptance of change, or the differential access to novelties, is a feature in the dynamics of social change common to both the past and the present.

\section{The Atlantic region}

Considering that Atlantic Art was already in use in the 4th millennium $\mathrm{BC}$ brings about a number of questions that ought to be addressed, particularly the contingencies of the historical processes underlying its dissemination across vast areas of Western Europe and the specificities of the socio-cultural contexts in which they were adopted. These may explain regional variations, even though the basic design grammar is consistent across its distribution area (Bradley 1997; Sharpe 2012; Valdez-Tullett 2019). If we take the wider picture of Atlantic and megalithic art across Atlantic Europe, we see the near absence of megalithic art in Britain and the virtual absence of Atlantic Art open-air carvings in Brittany. Both converge in Ireland and northwestern Iberia, even though they are not formally alike, they share the abstract, curvilinear, geometric imagery style that also characterises Atlantic Art.

As far as our study area is concerned, the overlapping of Atlantic Art and Bello's 'north-western group of megalithic art' in the late 5 th/early 4 th millennium $B C$ is coincident with the advent of the earliest domesticated animals and plants by essentially hunter-gatherer and mobile societies (Monteiro-Rodrigues 2011; Cruz 2001), dwelling in a land powerfully imprinted with carved symbols invading the slopes of entire hills and massive tombs.
Both Atlantic and Schematic Art were used as means of establishing bounds with the land across large territories unlike any earlier and later events of similar nature. If we accept the percolation model in which societies, responding to similar stimulus, accepted or rejected innovations according to their own common ancestry, it needs to be explained why did communities on both sides of the central mountain range adopted different languages of signs, and why the presence of megalithic tomb building is so conspicuous towards western and central parts of northern Portugal and so modest in the north-east.

The possibility of a close relationship between Atlantic Art and monumental architecture towards the coast helps framing the debate around the behaviour of both phenomena at the end of the sequence, as the dynamics of the use and reuse of megaliths in the 3rd millennium $\mathrm{BC}$ is somehow analogous to that of rock art. According to D. Cruz, megalithic tombs are closed and cease to be constructed by the end of the 4th/early 3rd millennium BC (2001). From then on, tombs become less conspicuous and although built under the same basic principles - structures under mounds - they do not enclose megalithic chambers but rather cists or pits for individual burials and tend to be found in the vicinities of ancient monuments (2001: 318). The Neolithic ideological superstructure and 'modes of doing' start to collapse, although social memory is still attached to the old dolmens and passage graves throughout the region. The author further suggests that the ways Copper Age burials were placed within earlier tombs by opening a way through the mound into the chamber recalls similar practices in burial caves and rock shelters (Cruz 2001: 318). The systematic reuse of earlier monuments may be related, as R. Bradley suggested (2002), with the need to create a sense of continuity during periods of social and political change.

As far as the Atlantic Art sequence is concerned, we argued that the representation of metalwork was episodic and intrusive in terms of its long timespan (Alves 2003). The addition of novel imagery on previously carved rocks recalls the intrusion of beakers and metalwork as grave goods in ancient megalithic tombs. Likewise, rocks carved ex novo showing exclusively weapons appear either at close distance from ancient carvings, in the periphery of large assemblages or at entirely new locations. For instance, the study of Monte Faro rock art showed that when weapon carvings are accompanied by circular motifs these tend to show slight nuances by comparison with classic compositions, e.g. being oval in shape instead of circular, devoid of a central cup-mark and not linked with wandering lines (Alves and Reis 2017) (Figure 6). It is always important to bear in mind when discussing the rise and fall of rock art traditions that we need to distinguish between the prevalence of individual motifs (form) and meaning 


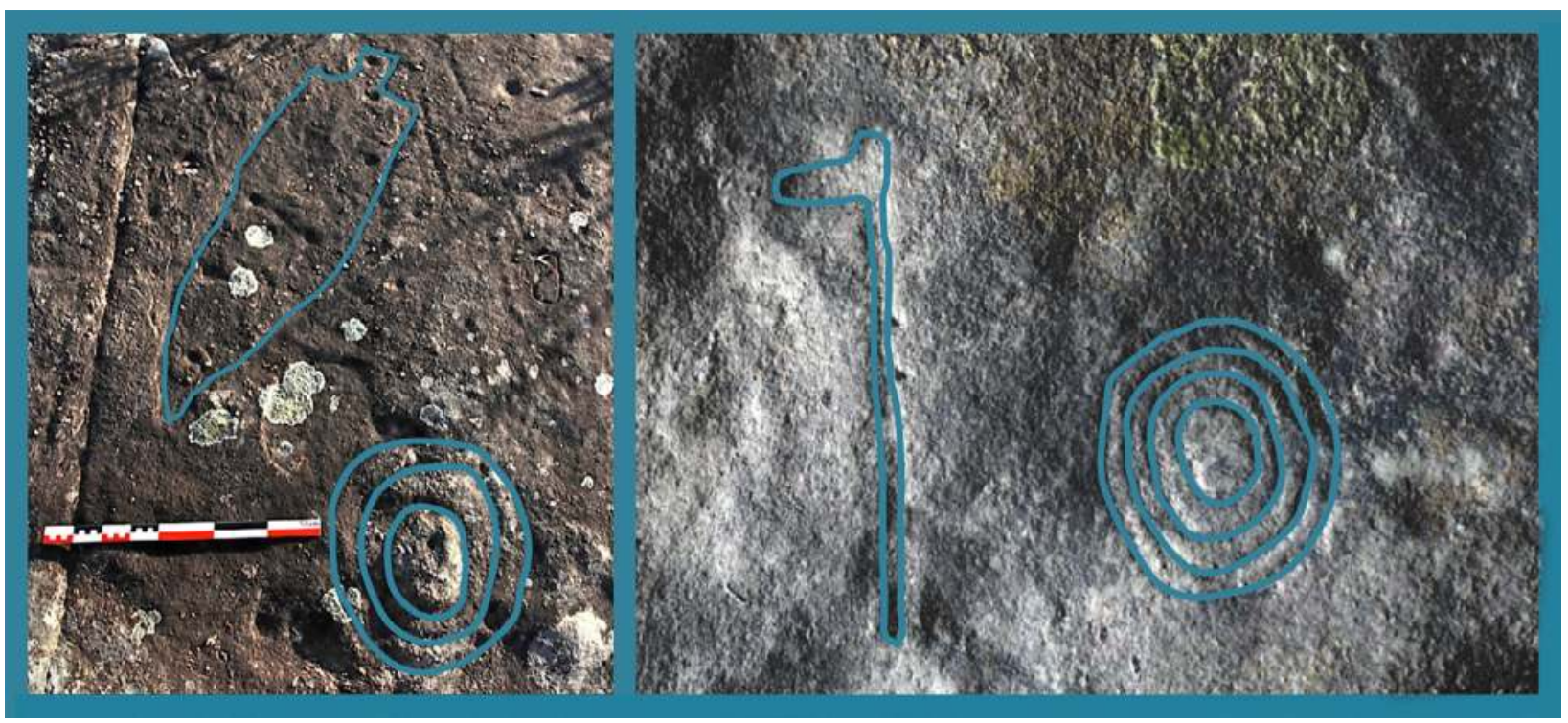

Figure 6 - Two weapon motifs carved alongside sets of concentric oval figures at Monte Faro (Valença, Portugal): an oversized dagger on Monte da Lage - rock 1 (on the left) and a halberd on Santo Ovídio - rock 3.

(essence), given that form may prevail, yet when meaning is adapted to new ontologies, changes may be detected in the arrangement of motifs in a composition or in their interaction with the backdrop.

Following this line of reasoning, it is likely that the creation of what I once called 'tattooed landscapes', referring to the nature of the sites created by Atlantic Art (Alves 2012), started to cease in the 3rd millennium BC with the permeability of new materialities and practices of Mediterranean origin, but that took place alongside a striking need to preserve 'identity' through the reenactment with old sites. The intrusion of metalwork in both burial monuments and rock art may be also related with the symbolic role of these items. Metalwork is the product of an unparallel transformation of matter, as rocks were quarried, heated and converted into metal. To some extent, the earliest carvings of weapons could be seen as an act of devolution of matter to its source (Alves and Comendador 2009). The deposition of copper axes in the fissures of two outcrops displaying Atlantic Art in Galicia further emphasises the symbolic reuse of old sites and the solid connection between the earliest metalwork and Atlantic Art in the northwest. The emphasis on the representation of daggers and halberds, added to the fact that the practice of carving weapons was short lived, suggests that the new ontologies underlying the emergence of metalwork may have been appropriated by the segment of societies that had already been the repository of the cosmological knowledge that lies at the foundations of the planning and construction of Atlantic Art 'tattooed landscapes' (Alves 2003).

Therefore, the dawn of the Bronze Age seems to mark the end of the great prehistoric art traditions characterised by the establishment of intimate and sensorial bounds to the surface of the land and opens the way for an hegemonic presence of sculpture in the archaeological record. This does not imply that new carvings ceased to be produced or added on to old sites, but no longer as an institutionalised, canonical practice, driven by particular sets of beliefs meant to be imprinted in the landscape. At the same time, we see new and increasingly different backdrops being used for applying symbolic imagery: artefacts, statues and stelae. Perhaps from the Bronze Age onwards, the depiction of carvings on natural rock formations (and the same applies for paintings), became a non-canonical practice restricted to peripheral spheres of society, not unlike what happened later, in historical periods.

The permeability of ideas and materialities of Mediterranean origin in the $3 \mathrm{rd}$ millennium $\mathrm{BC}$ prompted a syncretism between indigenous and foreign traditions, as the means of adapting innovations to the fabric of societies and the local modes of doing things. Copper Age statue-menhirs are largely absent from the far north-west, with the exception of that from Ermida, which in formal terms seems to be inspired in its Mediterranean counterparts, but the decoration shows some affinities to the geometric and curvilinear design grammar of open-air rock art (Baptista 1985) (Fig. 8). Along the 'transition area', there are more canonical examples, like the statue-menhirs of Nave and Alto da Escrita (Cruz 2001: 318). The sculpture of bodies in stone, their decoration and placement in the landscape, entails completely different technical and conceptual ideas if compared with rock art. Apart from being exemplars of the increasing preponderance of the individual, the morphology, graphic components and the choice of their physical setting are all 
driven by human determination, whereas in rock art the selection of designs and the properties of the backdrop are mutually dependent (Alves 2014: 28-29). Gradually, the umbilical link to the 'skin' of the land and to natural architecture gives way to new forms of transforming and manipulating matter. For some, the end of the 3rd (Bueno and Balbin 2010) or the first half of the 2nd millennium BC (Vilaça et al. 2001) marks the incorporation of metalwork items in sculpture. Armed statue-menhirs seem to have been one of the first phenomenon, as far as prehistoric art is concerned, to reach north-western areas from the east and south of Iberia in its conventional form (Fig. 9). Despite obeying to a set of design rules, these pieces are stylistically heterogeneous across northern Portugal, being locally produced and seeming to depend on the skills and readings of the canon by local communities (e.g. Alves and Reis 2011).

\section{Concluding remarks}

In his discussion of the concepts of time in Archaeology, G. Bailey argued that an expanded time perspective alters our conception of the relationship between 'larger-' and 'smaller-scale' factors and the cause/ effect relations between them (2005: 270). This contribution attempted to show how adjustments in the hermeneutics open a range of new possibilities for interpreting the cultural and social dynamics of late prehistoric art, supported on the following principles:

- The use of wide and dialectical scales of analysis to investigate the asymmetrical character of social, cultural and political temporalities, spatialities and materialities.

- Thinking about how and why innovations were adopted, resisted or rejected according to former common ancestry, implying a reflection on 'identity' and 'otherness'.

- Consideration of the coexistence of societies with different ways of life, ideologies, relations to the land, and socio-economic strategies in neighbouring regions with different ecosystems.

- Attending to the relationship between centre and periphery in the dynamics of historical processes.

The possibilities brought about by studying in parallel the role of monumental architecture and rock art traditions in the creation of neolithic landscapes is based primarily on an assessment of the nature of both phenomena. They are both means of anchoring social narratives onto the physical space, providing that underlying cosmologies are themselves anchored in the natural world (Alves 2003). In the Atlantic area, the reuse, incorporation, or deposition of new materialities in stone-built monuments and Atlantic Art sites is rather alike in conceptual terms.
Regarding the debate around the first evidence of change in the transition from the 3rd to the 2nd millennium BC, Lopes and Bettencourt hold that the hinterland seems to have largely maintained social dynamics intact across the 3rd millennium $\mathrm{BC}$, in contrast with the north-western region, where traditional contexts were disrupted by visible changes in the funerary sphere and the emergence of the first copper weapons and silver and gold ornaments in the second half of the millennium (2017). This is interpreted as the earliest evidence of the social tensions that would promote the rise of the new elites who led the network of inter-regional contacts (Lopes and Bettencourt 2017: 483). Yet, alternatively (or complementarily) the evidence for an apparent, more radical, change affecting the foundations of the 'ancient world' in the north-west may also be explained by the different character and degree of the impact that the advent of innovations and the wider opening to supra-regional contacts might have had in 'Atlantic' societies. It should be taken into account that the north-east region had always been more permeable to Mediterranean influences, regarding the example of the adoption of painted Schematic Art in the Early Neolithic. Despite the range of innovations visible from the beginning of the 3rd millennium $\mathrm{BC}$ in the northeast - walled enclosures, anthropomorphic stelae, new styles of pottery decoration - the traditional spheres of the symbolic and burial practices do not seem to have been substantially affected. In contrast with the northwest, images of weapons do not invade the figurative repertoire of Schematic Art, ${ }^{5}$ but are going to be found mainly in sculpture. This launches important questions about the simultaneous use, in time and space, of the old Schematic Art painting sites and a new class of places marked by stelae of Mediterranean influence, which are entirely different in conceptual grounds. Could it be that segments of the population, socially distant from the emergent spheres of power, and more vigorously attached to the old ways, kept the ritual use of Schematic Art sites as systems of belief characterised by entirely novel practices, and material display started to be established? Nevertheless, the apparently less significant disruption of the symbolic realm in the north-east may be related to a more conciliatory

\footnotetext{
5 Although representations of metalwork and weapons in particular are virtually absent from Schematic Art paintings, the recent finding of an open-air rock art site - Vale de Figueira - rock 1 - in eastern Trásos-Montes showing the carvings of daggers and an halberd (Silva et al.2018) reinforces the idea of a greater permeability between eastern and western regions of northern Portugal in the transition between the $3 \mathrm{rd}$ and the 2 nd millennia BC. It is also interesting to note the similarities between one of the daggers on this site and the smaller dagger carved at Monte da Laje - rock 1, located towards the Atlantic coast. The resemblance is striking as far as the morphological features of the blade are concerned as they both display a slight curve on one edge and a straight line on the opposite. Also, not only they are both oversized images, but have nearly the same dimensions, with the former measuring $0,62 \mathrm{~m}$ in length and $18,5 \mathrm{~m}$ in width (Silva et al. 2018) and the dagger from Monte da Laje, with a length of $0,60 \mathrm{~m}$ and 0,24m wide (Silva and Cunha, 1981: 151).
} 
embracing of innovations in a region linked, by tradition, to Mediterranean cultural environments and networks. Conversely, in the Atlantic north-west changes may have been more disruptive and tense, given that this region seems to have built and consolidated rather autonomous identity features in the Neolithic, as the symbolic and funerary spheres show. Despite attempts to preserve the 'old ways of doing things', visible in the syncretism of local and foreign referents, it appears that from the 2nd millennium BC, innovations start to be found in the north-west in their canonical forms.

Hence, the study of rock art allows us to recognise a shift of the symbolic order in the transition from the 3rd to the 2nd millennium BC, which we may actually consider a symbolic revolution, as described by $\mathrm{P}$. Bourdieu, that, if successful, alters the categories of perception used to understand representations of the world, and even the world itself in a given social and temporal context, transforming cognitive and social structures (Alves, 2014).

It should be noted however that setting the conditions for an extended debate on the ways in which innovations are adopted, resisted or rejected across the northwest of Iberia in late prehistory will surely be more fruitful if accompanied with a thoughtful discussion on the advances of archaeological thought. As far as rock art is concerned, we attempted to illustrate that this evidence, usually seen as marginal in prehistoric studies, may bring '...unexpected (...) revelations that ought to influence, in the future, the ways we think about the Late Prehistory of northern Portugal.' (Alves 2003: 421).

\section{References}

Aguiar, C. 2008. Biogeografia e uso do território, in Atlas das aves nidificantes em Portugal: 41-50. Instituto da Conservação da Natureza e da Biodiversidade. Lisbon: Assírio \& Alvim.

Alves, L.B. 2003. The Movement of Signs. Post-glacial rock art in north-western Iberia. Unpublished PhD thesis, University of Reading.

Alves, L.B. 2009a. O sentido dos signos - reflexões e perspectivas para o estudo da arte rupestre do pós-glaciar no Norte de Portugal, in R. de Balbín Behrmann (ed) Arte Prehistórico al aire libre en el sur de Europa: 381-413. Leon: Junta de Castilla y Leon.

Alves, L.B. 2009b. Signs on a rock veil: work on rocks, 'prehistoric art' and identity in north- west Iberia, in B. O'Connor, G. Cooney and J. Chapman (eds) Materialitas: working stone, carving identity: 169-180. Prehistoric Society Research Papers No 3. Oxford: Oxbow Books in association with UCD Humanities Institute of Ireland.

Alves, L.B. 2012. The circle, the cross and the limits of abstraction and figuration in north-western Iberian rock art, in A. Cochrane and A. Jones (eds) Visualising the Neolithic: abstraction, figuration, performance, representation: 198-214. Neolithic Studies Group Seminar Papers 13. Oxford: Oxbow Books.

Alves, L.B. 2014. Intermitências: a arte e a Idade do Bronze no Ocidente peninsular, A Idade do Bronze em Portugal. Antrope: 15-51. Série monográfica Em linha n¹, Tomar: Centro de Pré-história, Instituto Politécnico de Tomar.

Alves, L.B., Bradley, R., Fábregas Valcarce, R. 2013. Tunnel visions: a decorated cave at El Pedroso, in the light of fieldwork. Proceedings of the Prehistoric Society 79: 193-224. Cambridge: Cambridge University Press.

Alves, L.B., Comendador Rey, B. 2009. Rochas e Metais na Pré-História para além da Físico-Química, in A.M.S. Bettencourt and L. Bacelar Alves (eds) Dos Montes, das Pedras e das Águas. Formas de Interacção com o Espaço Natural da Pré-história à Actualidade: 37-54. Braga: Ed. Centro de investigação Transdisciplinar 'Cultura, Espaço e Memória' - CITCEM/Associação Portuguesa para o Estudo do Quaternário - APEQ.

Alves, L.B., Comendador Rey, B. 2017. Arte esquemático pintado en el noroeste peninsular: una visión integrada transfronteriza. Gallaecia 36: 11-52.

Alves, L.B. and Reis, M. 2011. Memoriais de Pedra, símbolos de identidade. Duas novas peças escultóricas de Cervos (Montalegre, Vila Real). IV Jornadas Raianas 'Estelas e estátuas-menir da Pré à Proto-história': 187-216.

Alves, L.B. and Reis, M. 2017. Tattooed landscapes. A reassessment of Atlantic Art distribution, research methods and chronology in the light of the discovery of a major rock art assemblage at Monte Faro (Valença, Portugal). Zephyrus, vol. LXXX: 49-67. Salamanca. Universidad de Salamanca.

Bailey, G. 2005. Concepts of time, in C. Renfrew and P. Bahn Archaeology. The key concepts: 268-273. London and New York: Routledge.

Baptista, A.M. 1983. O complexo de gravuras do Vale da Casa (Vila Nova de Foz Côa). Arqueologia 5: 57-69.

Baptista, A.M. 1983-1984. Arte Rupestre do Norte de Portugal: uma perspectiva. Actas do Colóquio InterUniversitário do Noroeste, Porto 1983, Portugália, Nova série, IV-V: 71-82. Porto: Instituto de Arqueologia da Faculdade de Letras da Universidade do Porto.

Baptista, A.M. 1985. A estátua-menir da Ermida (Ponte da Barca, Portugal). 0 Arqueólogo Português, 4a série, vol. 3: 7-44. Lisboa: Museu Nacional de Arqueologia,

Baptista, A.M. 1997. Arte megalítica no planalto de Castro Laboreiro. Brigantium 10: 191-216.

Bello Diéguez, J.M. 1995. Arquitectura, arte parietal y manifestaciones escultoricas en el Megalitismo noroccidental, in F.P. Losada and L. Castro Pérez (eds) Arqueoloxía e arte na Galicia Prehistórica e Romana. Monografias 7. A Coruña: Museu Arqueolóxico e Histórico de A Coruña. 
Bradley, R. 1997. Rock art and the Prehistory of Atlantic Europe. Signing the Land. London/New York: Routledge.

Bradley, R. 2002. The Past in Prehistoric Societies. London/ New York: Routledge.

Bradley, R. 2020. A Comparative Study of Rock Art in Later Prehistoric Europe. Cambridge: Cambridge University Press.

Bradley, R. and Fábregas Valcarce, R. 1998. Crossing the border: contrasting styles of rock art in the Prehistory of north-west Iberia. Oxford Journal of Archaeology 17(3): 287-308.

Bueno Ramírez, P. and Balbin Behrmann, R. 1992. L'árt mégalithique dans la Penínsule Ibérique: une veu d'ensemble. L'Anthropologie 96: 499-572.

Bueno Ramírez, P. and Balbin Behrmann, R. 2009. Marcadores gráficos y territorios tradicionales en la Preshistoria de la Península Ibérica. Cuadernos de Prehistoria y Arqueologia de la Universidad de Granada 19: 65-100.

Bueno Ramírez, P., Barroso Bermejo, R. and Balbin Behrmann, R. 2010. Metal and the symbols of ancestors in northern Iberia, in A.M.S. Bettencourt, M.J. Sanches, L.B. Alves and R. Fábregas Valcarce (eds) Conceptualising Space and Place. On the role of agency, memory and identity in the construction of space from the Upper Palaeolithic to the Iron Age in Europe: 71-87. British Archaeological Reports International Series 2058. Oxford: Archaeopress.

Carrera Ramírez, F. 2011. El arte parietal em monumentos megalíticos del Noroeste Ibérico. Valoración, diagnóstico, conservación. British Archaeological Reports International Series 2190. Oxford: Archaeopress.

Carvalho, P.S. and Alves, L.B. 2018. A Necrópole da Lobagueira, Viseu: expressões de arte e arquitectura da Beira Alta, Portugal, in J.C. Senna-Martinez, M. Diniz and A.F. de Carvalho (eds) Actas do colóquio 'De Gibraltar aos Pirinéus. Megalitismo, vida e morte na fachada Atlântica peninsular'

Cochrane, A. and Jones, A.M. 2018. Materials, process, image. The art of Neolithic Britain and Ireland, in A.M. Jones and A. Cochrane The Archaeology of Art. Materials, Practices, Affects. London/New York: Routledge.

Costa, J.C., Aguiar, C., Capelo, J., Lousa, M. and Neto, C. 1998. Biogeografia de Portugal Continental. Quercetea 0: 5-56.

Cruz, D.J. 2001. O Alto Paiva: megalitismo, diversidade tumular e práticas rituais durante a Pré-história Recente. Unpublished PhD thesis, University of Coimbra.

Cunha, A.L. 1995. Anta da Arquinha da Moura (Tondela), in $1^{\circ}$ Congresso de Arqueologia Peninsular. Actas VII, TAE 35(3): 133-152. Porto: SPAE.

Domingo Sanz, I., Fiore, D. and May, S.K. 2009. Archaeologies of Art. Time: Place, Identity in Rock Art, Portable Art and Body Art. One World Archaeology Series. Walnut Creek, CA: Left Coast Press.
Eogan, G. and Clearly, K. 2017. Excavations at Knowth 6. The Passage Tomb Archaeology of the Great Mound at Knowth. Dublin: Royal Irish Academy.

Fábregas Valcarce, R. and Rellán Rodríguez, C. 2012. A media luz. Grabados de la Prehistoria Reciente em abrigos galaicos. Trabajos de Prehistoria 69, ํo 1: 80102.

García Alén, A. and Peña Santos, A. d. 1. 1980. Grabados rupestres de la provincia de Pontevedra. A Coruña: Fundación Barrié de la Maza.

Johnson, S. 1993. The relationship between prehistoric Irish rock art and Irish passage tomb art. Oxford Journal of Archaeology 12(3): 257-279.

Jones, A.M. and Díaz-Guardamino, M. 2019. Making a Mark: Image and Process in Neolithic Britain and Ireland. Oxford: Oxbow Books.

Jones, A.M., Freedman, D., O'Connor, B. and LamdinWhymark, H. 2011. An Animate Landscape: Rock Art and the Prehistory of Kilmartin, Argyll, Scotland. Oxford: Oxbow Books.

Jorge, S.O. 1991. A ocupação do espaço no Norte de Portugal durante o III - inícios do II milénio A.C., in V.O. Jorge and S.O. Jorge (eds) Incursões na Préhistória: 299-380. Porto: Fundação Eng. António de Almeida.

Jorge, S.O. 1999. Domesticar a Terra. Trajectos Portugueses. Lisboa: Gradiva.

Jorge, V.O., Baptista, A.M., Jorge, S.O., Sanches, M.J., Silva, E.J., Santos Sanches, M. and Leite da Cunha, A. 1988a. O abrigo com pinturas rupestres da Fraga d'Aia (Paredes da Beira, S. João da Pesqueira) notícia preliminar. Arqueologia 18: 109-130.

Jorge, V.O., Baptista, A.M., Sanches, M.J. 1988b. A Fraga d'Aia (Paredes da Beira, S. João da Pesqueira) - Arte rupestre e ocupação Pré-histórica. Trabalhos de Antropologia e Etnologia 28(1-2): 201-233.

Kristiansen, K. 2005. Innovation and invention independent event or historical process? in C. Renfrew and P. Bahn Archaeology. The key concepts: 151-155. London/New York: Routledge.

Leisner, G. 1934. Die Malereien des Dolmen de Pedra Coberta. Jahrbuch für prähistorische und ethnographische kunst. Berlin: de Gruyter.

Lopes, S.S. and Bettencourt, A.M.S. 2017. Para uma periodização da pré-história recente do norte de Portugal: da segunda metade do $4^{\circ}$ milénio aos finais do 3ำ milenio AC, in Arqueologia em Portugal/2017 Estado da Questão - Actas do II Congresso da Associação Portuguesa de Arqueólogos: 467-487. Lisbon: University of Lisbon.

Lopes, S.S. and Gomes, S. 2018. Entre o 30 e o 20 milénio AC: que tipo de viragem? - Introdução, in Entre o 30 e o 20 milénio AC: que tipo de viragem? Seminário Internacional: 2-4. Coimbra: Centro de Estudos em Arqueologia, Artes e Ciências do Património.

López Cuevillas, F. 1948. El Noroeste de Portugal y el arte megalítico. Archivo Español de Arqueologia 15: 225-254. 
Meskell, L. and Preucel, R.W. 2008. Companion to Social Archaeology. Chichester: John Wiley \& Sons.

Needham, S. and Cowie, T. 2012. The halberd pillar at Ri Cruin cairn, Kilmartin, Argyll, in A. Cochrane and A.M. Jones (eds) Visualising the Neolithic: abstraction, figuration, performance, representation: 89-110. Neolithic Studies Group Seminar Papers 13. Oxford: Oxbow Books.

Peña Santos, A. and Rey García, J.M. 1993. El espacio de la representación. El arte rupestre galaico desde una perspectiva territorial. Revista de Estudios Provinciais 10: 11-50.

Peña Santos, A. and Rey García, J.M. 2001. Petroglifos de Galicia. A Coruña: Via Láctea.

Monteiro-Rodrigues, S. 2011. Pensar o Neolítico Antigo. Estudos Pré-históricos 16. Beira Alta: Centro de Estudos Pré-históricos da Beira Alta.

Reis, M., Alves, L.B., Cardoso, J.M., Carvalho, B. 2017. Art-facts - os contextos arqueológicos da Arte Esquemática no Vale do Côa, in S. Garcês, H. Gomes, A. Martins and L. Oosterbeek (eds)

Shanks, M. and Tilley, C. Techne 3(1), Arte das Sociedades Pré-históricas (Actas do IV Congresso de Doutorandos e Pós-doutorandos, 26-29 de Novembro, Mação, 2015): 9711.

Sanches, M.J. 1997. Pré-história Recente de Trás-osMontes e Alto Douro. Porto: Sociedade Portuguesa de Antropologia e Etnologia.

Shanks, M. 1987. Social Theory and Archaeology. Oxford: Polity Press/Basil Blackwell.

Sharpe, K. 2012. Reading between the grooves: regional variations in the style and deployment of 'cup and ring' marked stones across Britain and Ireland, in A. Cochrane and A.M. Jones (eds) Visualising the Neolithic: abstraction, figuration, performance, representation: 47-63. Neolithic Studies Group Seminar Papers 13. Oxford: Oxbow Books.

Shee Twohig, E. 1981. The Megalithic Art of Western Europe. Oxford: Clarendon Press.

Shee Twohig, E., Roughley, C., Shell, C., O'Reilly, C., Clarke, P. and Swanton, G. 2010. Open-air rock art at Loughcrew, Co. Meath. The Journal of Irish Archaeology XIX: 1-28.

Shee Twohig, E. 2012. Inside and outside: visual culture at Loughcrew Co Meath, in A. Cochrane and A.M. Jones (eds) Visualising the Neolithic: abstraction, figuration, performance, representation: 125-139. Neolithic Studies Group Seminar Papers 13. Oxford: Oxbow Books.

Sheridan, A. 2012. Contextualising Kilmartin: building a narrative for developments in Western Scotland and beyond, from the Early Neolithic to the Late Bronze Age, Image memory monumentality, in A.M. Jones, J. Pollard, M. J. Allen and J. Gardiner (eds) Image, Memory and Monumentality - archaeological engagements with the material world: a celebration of the academic achievements of Professor Richard Bradley. Prehistoric Society Research Paper 5: 163-183. Oxford: Oxbow Books.

Schulting, R. 2014. Dating the construction of Newgrange, in A. Lynch Newgrange revisited: new insights from excavations at the back of the mound 19845: 46-50. Journal of Irish Archaeology 23.

Schulting, R., Ramsey, C.B., Reimer, P., Eogan, G., Cleary, K., Cooney, G. and Sheridan, A. 2017. Dating the Neolithic Remains at Knowth, in G. Eogan and K. Clearly (eds) Excavations at Knowth 6. The Passage Tomb Archaeology of the Great Mound at Knowth: 331386. Dublin: Royal Irish Academy.

Silva, A., Figueiredo, S.S.., Neves, D., Xavier, P. 2018. Sinais gravados da Idade do Bronze em Trás-osMontes oriental: rocha 11 de Vale de Figueira, in N. H. Gutiérrez, J. L. Galarza and R. P. Hernández (eds), Arqueología em el Valle del Duero: del Paleolítico a la Edad Media 6: 167-180. Valladolid: Glyphos

Silva, E.J.L. and Cunha, A.L. 1981. As gravuras do Monte da Laje (Valença), Arqueologia, 13: 143-158

Spellerberg, I.F. and Sawyer, J.W. 1999. An introduction to applied biogeography. Cambridge: Cambridge University Press.

Waddell, J. 2005. The Prehistoric Archaeology of Ireland. Galway: Galway University Press.

Waddington, C. 2005. Excavation of a rock art sites at Hunterheugh Crag, Northumberland. Archaeologia Aeliana 34: 29-54

Waddington, C. 2007. Cup and Rings and Passage Grave Art. Insular or Imported traditions?, in C. Burgess, P. Topping and F. Lynch (eds) Beyond Stonehenge. Essays on the Bronze Age in honour of Colin Burgess: 11-19. Oxford: Oxbow Books.

Valdez-Tullett, J. 2019. Design and connectivity. The case of Atlantic rock art. Archaeology of Prehistoric Art 1. British Archaeological Reports International Series 2932. Oxford: BAR Publishing.

Valera, A.C. 2018. Morte no Expresso do Ocidente: razões para um colapso social no final do 30 milénio a.C. no Sudoeste da Península Ibérica, in Entre o 30 e o 20 milénio AC: que tipo de viragem? Seminário Internacional: 34-39. Coimbra: Centro de Estudos em Arqueologia, Artes e Ciências do Património.

Vásquez Martínez, A., Fábregas Valcarce, R., and Rodríguez-Rellán, C. 2016. Going by the numbers, a quantitative approach to the Galician prehistoric petroglyphs, in R. Fábregas Valcarce and C. Rodríguez-Rellán Approaches to post-Palaeolithic rock art: 63-69. Proceedings of the XVII UISPP World Congress (1-7 September 2014, Burgos, Spain). Volume 5/Session A11e. Oxford: Archaeopress Archaeology. 


\title{
Chapter 4 \\ The Site of Areias Altas (Porto, Portugal): Current Knowledge of its Occupation in the first Half of the 2nd Millennium BC
}

\author{
Sara Luz \\ Archaeologist and Master's student at the University of Minho. \\ saradaluz@yahoo.com
}

\begin{abstract}
This text provides a knowledge update about Areias Altas: an archaeological site discovered in the early 1950s near the coast of Porto and vaguely attributed to the Bronze Age. To this end, I will first revisit the old excavation with its original interpretation and then present the data recently achieved by preventive archaeology work. The contemporary research has found that this is a large pit site, with a particular material culture, deeply connected with the adjacent marine environment and dating from the first half of the 2nd millennium BC. In addition, I draw attention to the distinctive features that make of Areias Altas a unique site in the context of the Bronze Age of northern Portugal, and in particular those that give depth to its social dynamics: the identification of deposition practices and the possibility of salt production through artificial evaporation.
\end{abstract}

Keywords: pits, Bronze Age, depositions, salt production.

\section{Introduction}

Areias Altas is a Bronze Age pit site located in Porto, near the sea, excavated by Russell Cortez (1952) in the early 1950s, and more recently due to housing construction. For decades, the data available was limited to this outdated excavation of ambiguous findings regarding the nature of the identified contexts, as well as archaeological material of apparently distinct chronologies and no general consensus. This contribution presents the main results of the preventive archaeology work, bridging with those published by Cortez. The new data have significantly improved our knowledge of the site, particularly regarding the type of features, associated materials and chronology. In addition, they have made it possible to draw up some scenarios that can help in understanding the character of the site and its social spatiality.

Despite the new excavations, much data is still unavailable, limiting the creation of a cohesive discourse. In order to overcome these constraints, the two best documented interventions are mainly used here as 'windows' to present the site. We can begin by presenting a summary of the history of the archaeological interventions at the site, providing an image of how fragmentary our actual view of the evidence is. An analysis will follow of the main aspects of the stratigraphy, the morphology of the features and pit fills, the artefactual assemblages, and the radiocarbon dates. Since this is an ongoing analysis, aspects that seem to stand out or are of special relevance are chosen to highlight each subject and see how they might contribute to an understanding of the particularity of the site. As a result of this analysis, two aspects can be stressed related to the social dynamics of the site: practices of deposition, and, possibly, salt production. The identification of deposition contexts has greatly benefited from the good preservation of the pit fills, thus enhancing their visibility. In the process of their recognition, what could be seen was a distinct form of material culture expressing itself, exposing its careful manipulation and intentional arrangement. As for salt production, this is a possibility that has only recently been posited, due to the identification of parallels for the most paradigmatic vessels of Areias Altas. This perception acted as a glimpse into other evidence of the site, whose meaning was, until then, both intriguing and opaque.

\section{History of the archaeological interventions at Areias Altas}

The site of Areias Altas is located near the coastal edge of the city of Porto, in the north-western region of Portugal. It was first discovered in the early 1950 s by Russell Cortez (1952), a local archaeologist who was interested in the prehistory of Porto. Since then, it has only been the scene of new archaeological works between 2008 and 2011, carried out in advance of housing construction. Figure 1 presents an image taken from Google Earth with the location of these works and the place indicated by Russell Cortez, later in the 1980s, for the digging he performed. ${ }^{1}$ This is a specific area within the city of Porto, mostly occupied by villas with large gardens and virtually no construction

I am grateful to Susana Soares Lopes for this information. 


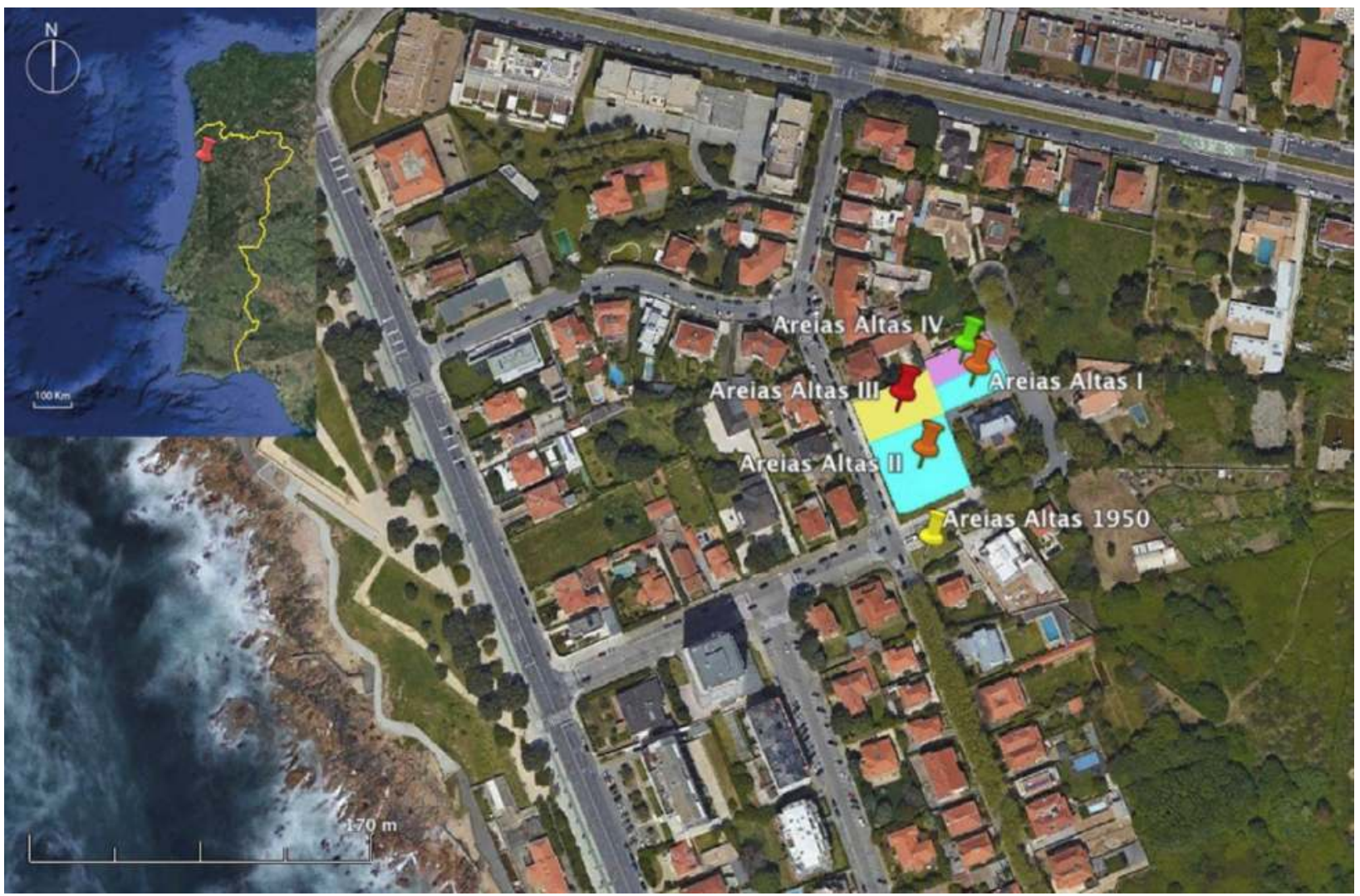

Figure 1. Location of the archaeological works at Areias Altas (Google Earth).

from north-east to south-east of the archaeological excavations, which means that future development may also contribute new data for the understanding of the archaeological site.

The site lies on the coastal platform, occupying a flattened surface between 21 and 23 masl, c. $300 \mathrm{~m}$ from the present coastline. The geological map depicts the convergence of different formations, such as PlioPleistocene beach deposits (from $15-20 \mathrm{~m}, 30-40 \mathrm{~m}$, 60-70 m), the schist-greywacke complex and eruptive rocks; in addition there are also landfill deposits near Castelo do Queijo beach. Archaeological fieldwork has confirmed the presence of the schist-greywacke complex, characterised by highly metamorphosed rocks transformed into phyllites, mica schists, gneisses, migmatites, etc., and eruptive rocks (granites), on the top of which the sandy-pelitic formation of probable Late Pleistocene origin has been identified (Araújo 1991).

Russell Cortez took advantage of the extension works on Marechal Saldanha street for digging 'in the place of Areias Altas - a raised beach of 30 meters' (1984:11). ${ }^{2}$ The results obtained were never fully published, but only sparse references and somewhat ambiguous and confusing data are known. Regarding the contexts

\footnotetext{
${ }^{2}$ Translations of the Cortez references are by the present author.
}

identified, Cortez refers to the presence of 'a dwelling dug into the alluvial deposit that provided gathering remains - pottery vessels, scrapers and quartzite weights', to which he adds the collection of 'clay remains that were used to garnish the palisade' (1984: 11-12); the Portal do Arqueólogo website also mentions the exhumation of ' 5 bases of conical vessel with basal ring, an almost complete ovoid vessel with side handle, fragments of great decorated vessels (knobs), lithic material, a saddle quern and mollusc valves. It is thought to be a dumping ground or a hut bottom'.

With regard to the archaeological materials, it was in the 1952 article that Russell Cortez published some drawings and more detailed information. The author presents an assemblage of pebble tools, mostly of pointed outline, and net weights (Figure 2), arguing for its association with the 'Asturian culture' (1952: 205) that developed in the north-west of the Iberian Peninsula during the Mesolithic. In addition, he refers to the presence of 'milling' and 'blushed stones' (probably thermo-altered) which Cortez suggests would have been used to cook 'floured cereals', and thus attributed to the Neolithic (1952: 210).

The ceramic repertoire includes vessels with a subcylindrical profile, ovoid, spherical with slight neck constriction, tronco-conical, ovoid with pedestal and widened base and a carinated bowl (Figure 2). These are 

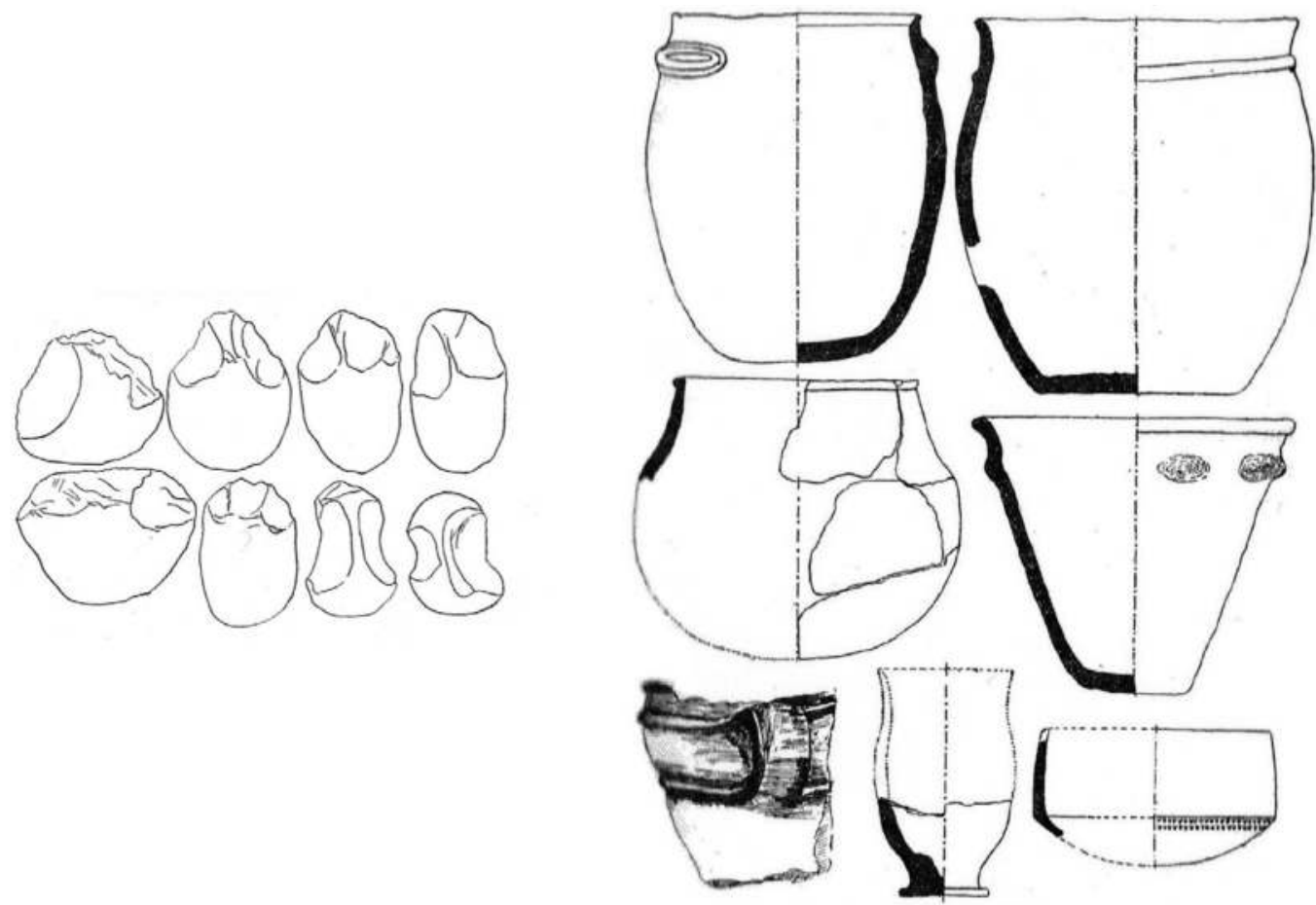

Figure 2. Ceramic and lithic materials published by Russell Cortez (1952: 204; 231).

mostly flat-based forms with plastic decoration below the rim (cordons and knobs) with the possibility of some puncturing (?) in the lower part of the bulge of the carinated bowl: in particular, Cortez mentions that this is a fragment of a 'dark, highly polished, carefully made and richly decorated pot' (1952: 230). As for chronology, Cortez attributes the ceramic vessels to the Neolithic, although he admits that they may be contemporaneous with the 'Eneolithic (Bronze I)', given the presence of pedestal vessels - of which he claims no other examples are known in Portugal - and the flat-based forms (1952: 229).

In addition to these materials, the author also mentions the presence of 'two bronze foundry rocks' (1952: 229) and mollusc shells, namely Patella (limpets) and Trochus (snails) (1952: 210), although the description at the Portal do Arqueólogo generally refers to shellfish valves (mussels?).

The proposal of a chronology for the recovered findings at Areias Altas was presented, in a more objective way, at the Seminário de Arqueologia Portuense in 1983. In the summary of his presentation, Cortez ascribes the occupation of Areias Altas to $2500 \mathrm{BC}$, based, above all, on the collection of 'a bronze foundry rock' (1984: 12). The transcription of the questions raised by the audience reveals the interest and the many doubts that the data presented posed, especially by the association, within the same level, of lithic industries of the Asturian tradition - with a hardly consensual chronology, held as palaeolithic by some researchers and post-palaeolithic by others - with pottery and evidence of metalworking that could be of the Bronze Age. ${ }^{3}$ This coexistence seems, however, to be interpreted by Cortez as an indicator of the persistence of archaic features among 'well-fed gatherer populations, whose location did not impose any reason that forced them to greatly modify their economy' (1952: 210).

In the last two decades of the 20th century, no other references to the site of Areias Altas are known, apart from those on the tronco-conical vessels in particular (Bettencourt 1995; 1999; Jorge 1986; Sanches 1980; 1981). The 2006 'Special Plan for Archaeological Protection' (PEPA 27 - Archaeological site of Areias Altas; CNS 4245) drawn up by the Municipality of Porto, put the site back into perspective, conditioning the area and demanding safeguarding measures due to the negative impact of building projects.

Between 2008 and 2011, preventive archaeology was carried out on four adjoining plots and the site where Russell Cortez first excavated, comprising an area of c. $3000 \mathrm{~m}^{2}$. These works were undertaken within the scope of commercial archaeology by different companies and distinct directors, and thus so to simplify the presentation of the results, the different projects are referred to here as Areias Altas I, II, III, IV (Figure 1). ${ }^{4}$ In general terms, the same type of measures

\footnotetext{
${ }^{3}$ Among the audience were Prehistory Professors from the Faculty of Arts and Humanities of University of Porto - Vítor Oliveira Jorge, Susana Oliveira Jorge, and João Pedro Cunha Ribeiro.

4 At Areias Altas I and II the archaeological works were contracted
} 


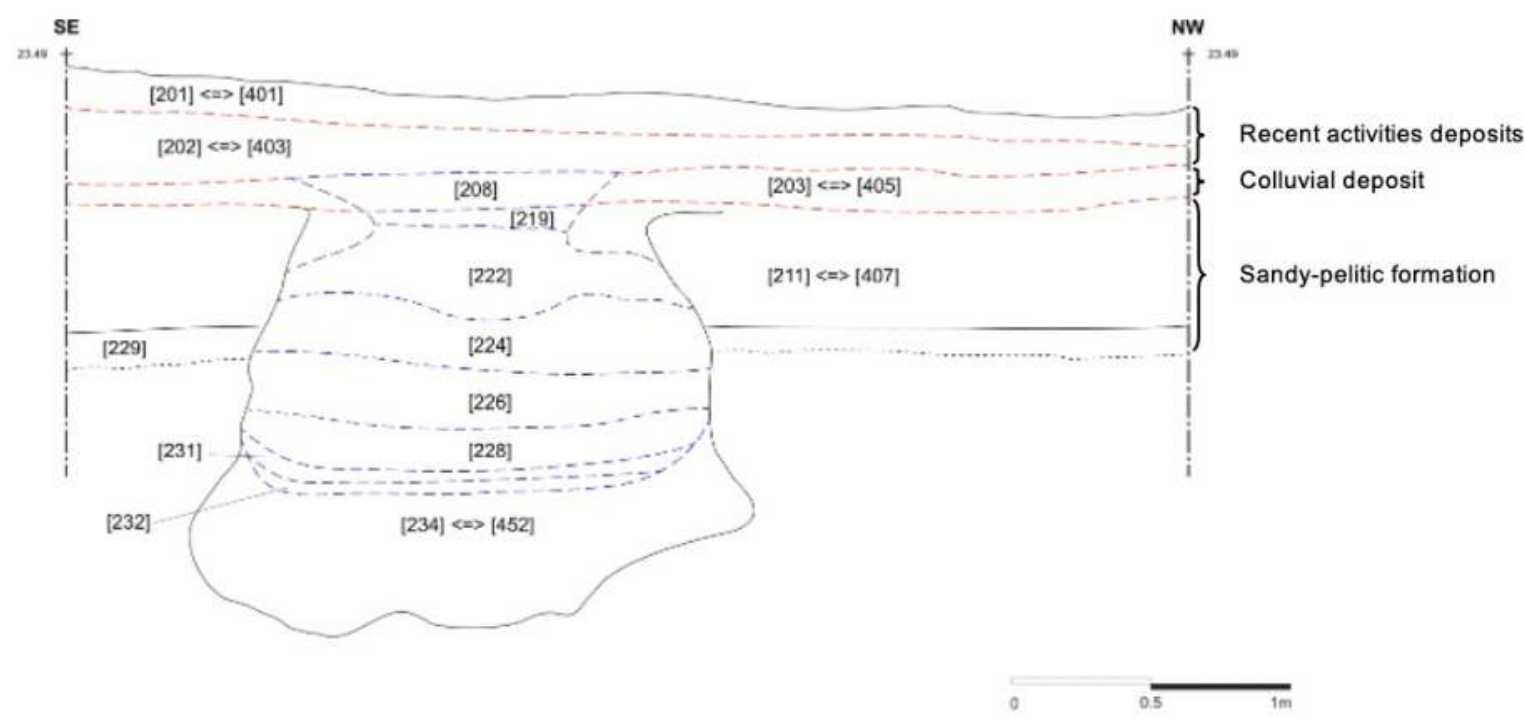

Figure 3. Stratigraphic profile of Structure 3 from Areias Altas I, recorded and re-interpreted.

have been established for all projects: a trench-based evaluation; full excavation of the identified contexts in the building areas; and archaeological supervision of the excavation developed by the contractor. The only exception occurred at Areias Altas IV, the first project to be executed, where, unfortunately, the in-depth excavation was already in an advanced stage when the Municipality of Porto became aware and stepped in, taking the due diligences: archaeological supervision of the remaining soil removal, allowing a first assessment of the stratigraphy, the collection of archaeological materials of prehistoric chronology, and confirming the archaeological potential of the area.

The results achieved allowed the identification of new contexts correlated with the site of Areias Altas and attested to its scientific relevance. With this framework more than 200 features were excavated, such as pits, post-holes and ditches. In association with these structures, ceramic and lithic materials of prehistoric chronology were recovered, with emphasis on the presence of well-preserved shell assemblages, which, in addition to their biological contribution (Cabral 2010; 2014), allowed the first absolute dates to be obtained.

\section{The stratigraphy of the site: a brief note}

The different areas had distinct land-use: Areias Altas I and IV corresponded to vacant lots that may previously have had an agricultural use; while at Areias Altas

out to Logiark; at Areias Altas I, direction was under João Paulo Barbosa, later in co-direction with the present author; at Areias Altas II the work was shared by the present author, João Paulo Barbosa, and Roger Prieto de La Torre; at Areias Altas III the works were contracted out to Etnos and directed by José Marcelo Mendes Pinto and Sónia Pereira; at Areias Altas IV the work was conducted by the Urban Archaeology Office team (GAU) from the Municipality of Porto.
II and III there were houses with garden areas and outbuildings. In this sense, the levels that overlapped the features were essentially characterised by the presence of traces related to recent activities, causing the disturbance of some contexts.

After the removal of these levels, a reddish-brown clay deposit was identified, which included a high frequency of lithic and ceramic materials. This was not a continuous deposit, however it could be observed that it covered both a natural deposit connected to the local geomorphological dynamics, the sandy-pelitic formation (Araújo 1991), and the top of the features. At Areias Altas I this deposit raised important questions, first in the field, and later during the post-excavation process. In fact, the analysis of the archaeological record allowed us to reconsider its interpretation, proposing that the top of one of the pits (Structure 3) occurred within this deposit (Figure 3). The hypothesis put forward is that of a colluvial deposit that presented a sharp thickening to the west, with values between 5 and $80 \mathrm{~cm}$, thus compensating for the slope on the top of the previous deposit. In this light, it seems reasonable to assume that, at least, the beginning of its formation should be contemporary with the occupation of the site.

At the base of the stratigraphic sequence the sandypelitic formation was identified, laying directly on the bedrock. When excavated, it turned out to be a group of sandy-clay deposits of yellowish spectrum, featuring at the base a sometimes dark brown, sometimes orangebrown layer, with inclusions of shale laminae and rolled pebbles; the former may result from the substrate disintegration, while the rolled pebbles may be: ' 1 - the elements that remain, in situ, of a dismantled deposit; 2 - elements dragged, by solifluction, from other places, 


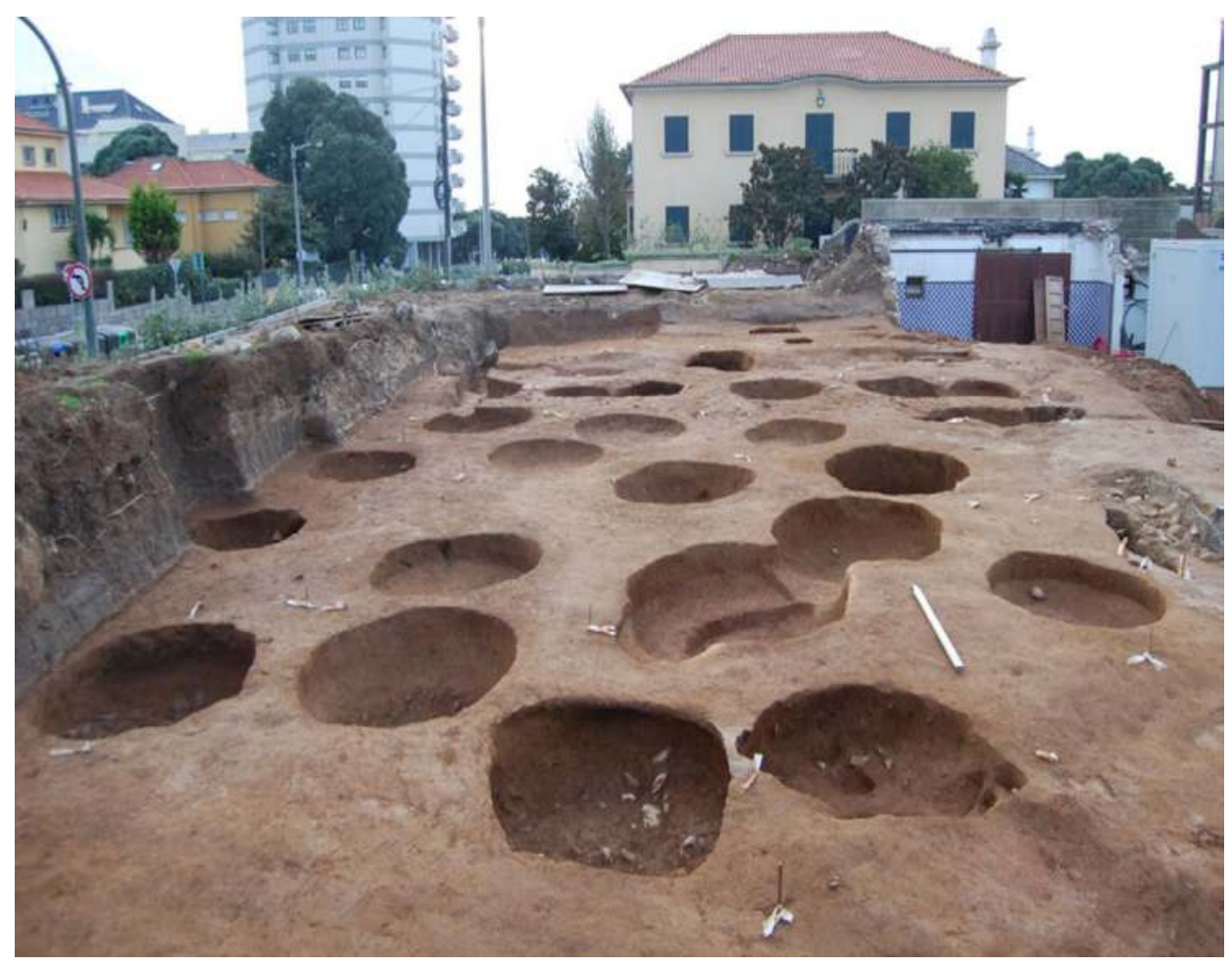

Figure 4. General view of the pits at Areias Altas II.

slightly higher, where it still exists, or previously existed, a deposit with rolled pebbles' (Araújo 1991: 361-362; present author's translation). The remaining structures were identified on the top of this formation, with several cutting its base level and a few also reaching the rocky substrate, giving them fairly uneven bases.

This said, the understanding of the site's stratigraphy resulted from the crossing of several readings made possible by the excavation strategy, analysing plans, sections (those of the diagnostic trenches having proved decisive), the features' sides, but also from the reflections developed subsequently on all these data.

\section{The features: main characteristics}

Overall, the preventive archaeological works allowed for the identification of over 200 features, the vast majority consisting of pits. At Areias Altas I and II, 113 were recorded, 74 of which corresponded to pit-type structures, 32 to post-holes, 6 to ditch segments, and with one not fitting any of these types.

\section{The pits}

From a morphological point of view, the pits had mostly a sub-circular plan and a spherical profile, but oval and sub-elliptical plans, and ovoid, cylindrical and tronco-conical profiles also occurred. It was found that at Areias Altas I the closed or very closed forms predominate, whereas at Areias Altas II we have the open forms; in the case of pits with a very closed form their profile usually presents a 'neck constriction' (Figure 3). At the base level an oscillation was observed between the concave and flattened forms, and, in the case of structures that reached the aforementioned pebble layer, and sometimes even the bedrock, the base form is essentially uneven.

At Areias Altas II there were also four structures with what seems to be a composite layout, i.e. similar to an ' 8 ', or an ' 8 ' with a small semicircle at one end, where each segment had distinct depths. Unlike other cases, in this group of structures no intercutting was detected, leading to the consideration of two scenarios: their initial design was a composite form consisting of two or three semi-circular segments, backfilled as a whole; or each of the segments at a previous time was a separate structure, later cut, eventually emptied, and again filled in together with others, leaving no traces of these actions.

As for their dimensions, it is noteworthy that the pits identified at Areias Altas II were, on average, much wider and shallower ( $140 \mathrm{~cm}$ long and $30 \mathrm{~cm}$ deep) than those of Areias Altas I; irrespective of their depth, it is certain that some have been truncated. Regarding size, the area of Areias Altas II is the closest to the locale indicated by Cortez, thus the features he found could be pits of similar dimensions, leading him to consider the presence of 'hut bases'. 
In terms of spatial distribution some differences were also observed, i.e. a very high density of pits at Areias Altas II (Figure 4) and III, with some cases of intercutting recorded. At Areias Altas I, these were more scattered, although there was a greater concentration of pits in the south-east area, and there were no intercuts.

Pits and fills: deposition contexts and other ambiguous deposits

In discussing the pit fills there are several aspects that should be highlighted. Overall, these were clay and sandy-clay matrix deposits, mainly identified on the basis of their colour and compactness variations. They had mostly horizontal and regular surfaces, although some could be arranged in a sloping, concave, or flat-convex way, with small concavities at the pits' sides, which gives them a certain 'plastic' character and suggests the existence of an intention (to close something?); also, these were always connected to deposits similar to the local substrate, containing few or no associated materials. It should be noted that only three pits were completely devoid of artefacts; the vast majority had both pottery and lithics (78\%), some had only lithics (12\%), and in four structures there were finds of pottery, lithics, and shells.

Concerning the number of fills, it is possible to observe a trend, related with pits containing between one and four fills (70\%), but also variability, since it is necessary to group categories so that numbers can gain expression, and, in this sense, structures containing between 5 and 10 fills (27\%) should not be overlooked (Figure 5).

Thus, the presence of well-preserved levels involving different kinds of materialities should be underlined. The excellent conditions of these levels have enhanced the identification of deposition contexts, so it is important to mention both Structure 12 and 15 (Luz 2010) of Areias Altas I, and Structure 66 of Areias Altas II, as the most remarkable examples (Figure 6). These pits stood out because they allowed us to understand a set of complex relationships not recognised in most structures. This difference manifests itself in the materials that have been deposited and in the way they make themselves noticed, bringing out their intentional placement and their articulation with others in elaborate and organised compositions in space.

The deposited materials consist of ceramics, lithics and shells, and may occur in a fragmented, partially fragmented and whole state. They may appear as massive deposits dominated by a specific category, such as fragments of pedestal vessels (Figure 6a), or shells (Figure 6b), or a mix of these two categories (Figure 6c); they may be homogeneous or heterogeneous clusters of

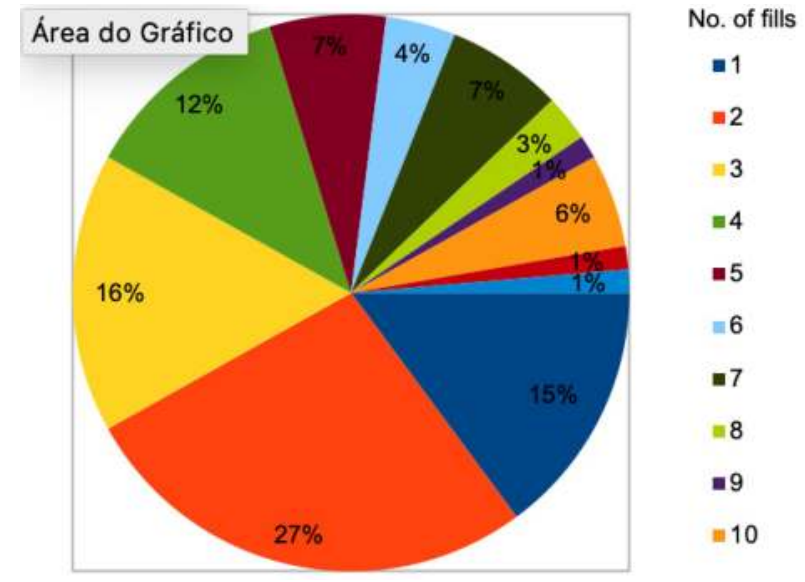

Figure 5. Distribution of the number of fills per pit.

lithics and ceramics; their presence may be conspicuous or discrete. We can say that the quality that best defines these materials is that of being 'extra-ordinary', in the sense that they well represent the archaeological record and number of activities likely to have occurred at Areias Altas (production, use and disposal of objects, fishing, mollusc collecting, salt production), but the frequency of some types of materials, their state of integrity, and their stories, is not trivial.

The formalisation of these contexts can be very diverse, although there seems to be a tendency towards concentric arrangement: some things occupy the centre, some occur around the centre, and others are distributed along the edges. This perception may suggest the existence of hierarchy, however, the way things intertwine, or stand out, undermines such a rigid scheme, transforming depositions into impressive images, a coherent whole. But these are not flat images, they play with depth and may incorporate elements from previous deposits. In this sense, there is also an additive logic in the filling sequence of these pits that cements this idea of unity, but now at the structure's scale.

In the various forms of depositions, there are some principles which have been decisive in their creation, including decision-making, on which materials can participate, being aware of the possible ways of combining them and proceeding with care. Being familiar with these principles and with a space, enables a connection between practices and a means of visibility of those practices. The depositions of Areias Altas articulate objects and actions that are only meaningful in relation to that place. And they do so by means that go beyond mere reference to the activities practised there, but rather seem to exalt the possibility of that place. 


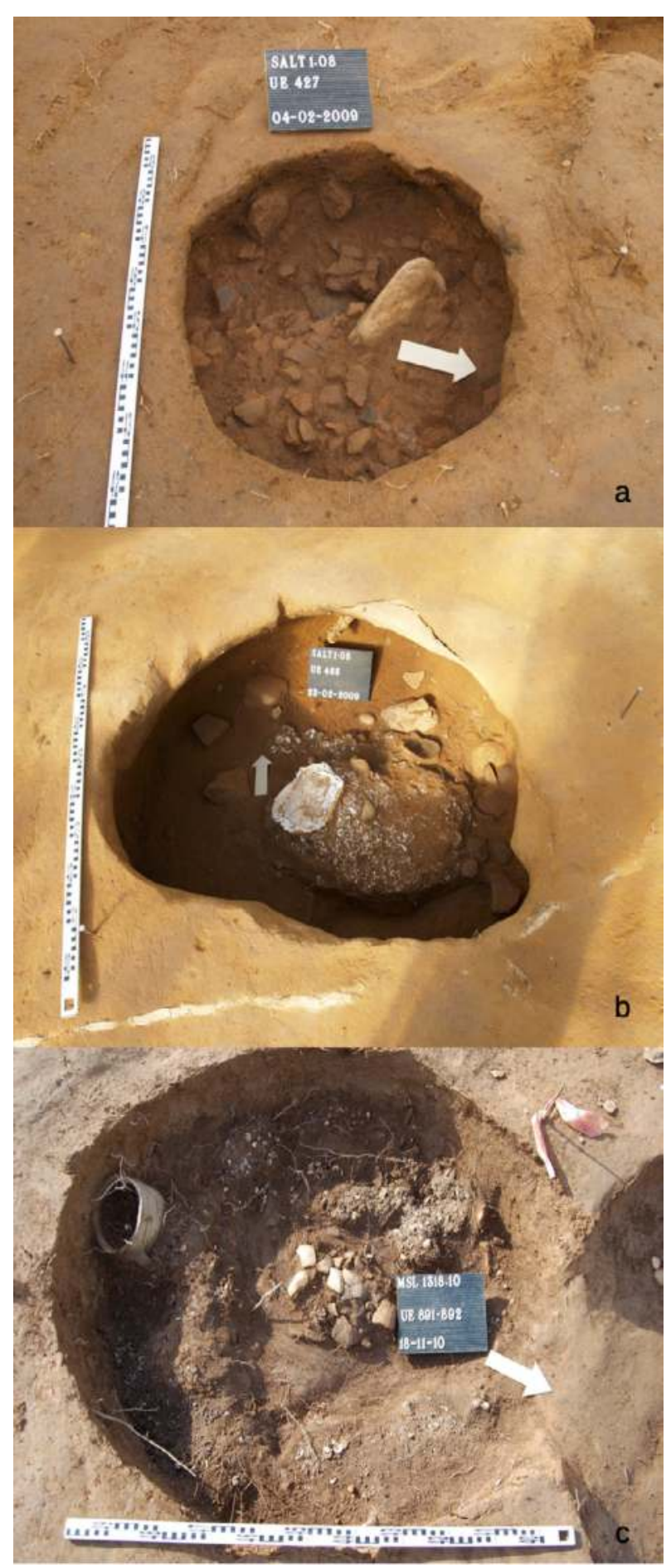

Figure 6. Examples of deposition contexts: (a) Structure 12 and (b) Structure 15 from Areias Altas I; (c) Structure 66 from Areias Altas II.

\section{Other features}

With the post-hole-type features, their morphology often depicts a sub-circular plan and profile between the ovoid and tronco-conical, with some variations; the base typology is usually concave; its diameter or major axis varies between 18 and $44 \mathrm{~cm}$, and its depth between 8 and $30 \mathrm{~cm}$. In terms of spatial distribution, these features often appear in clusters, evident in the presence of some alignments and occasionally appearing isolated near the pits.

As for the ditch segments, the following aspects should be highlighted: the only segment identified at Areias Altas I had an east-west orientation, an open U-shaped profile and a flattened base; at Areias Altas II they were all north-west/south-east oriented, inflecting slightly westwards, with mostly open U-shaped profiles, except for one which was V-shaped, and flattened bases, with small concavities present in their cuts that could extend from the sides to the base.

From a stratigraphic standpoint, it should be stressed that all the segments identified at Areias Altas II cut pittype structures. On the other hand, these are the only structures that raise doubts about their prehistoric framing and even about their anthropic origin. In fact, the associated materials were quite weathered and often related to distinct chronologies, namely Roman ceramics, to which, adding their cutting irregularities, the possibility of being paleo-channels should not be neglected.

\section{Artefact assemblages}

Most of the materials have been recovered from the pits fills and the following sections will mainly focus on these assemblages.

\section{Ceramics}

At Areias Altas I and II, the general picture from over 7500 potsherds is that of a rather fragmentary sample ( $84 \%$ of the sherds measure $\leq 5 \mathrm{~cm}$ ), consisting essentially of plain fragments (98\%). The vast majority belongs to vessel bodies (81\%), featuring eroded surfaces, particularly the internal ones, and fresh breaks. These are primarily related to coarse wares with medium to large size inclusions and smoothed surfaces, although a small number of fragments fit into fine wares with burnished finish. Despite the fragmented nature of the sample, the presence of large and well-preserved fragments within some features is noteworthy, highlighting some refits that provided large portions of vessels, as well as the presence of nearly complete shapes, although never in their integral state (Figure $7 b-d)$.

From the morphological point of view, it was possible to recognise all the types presented by Cortez, identifying at least one new form, probably a semi-spherical bowl, forming an assemblage in which flat-based forms predominate. Except for the carinated bowls and the pedestal vessels, the remaining types often include side handles attached, and a combination of handle with lug was also observed in the sub-cylindrical form 

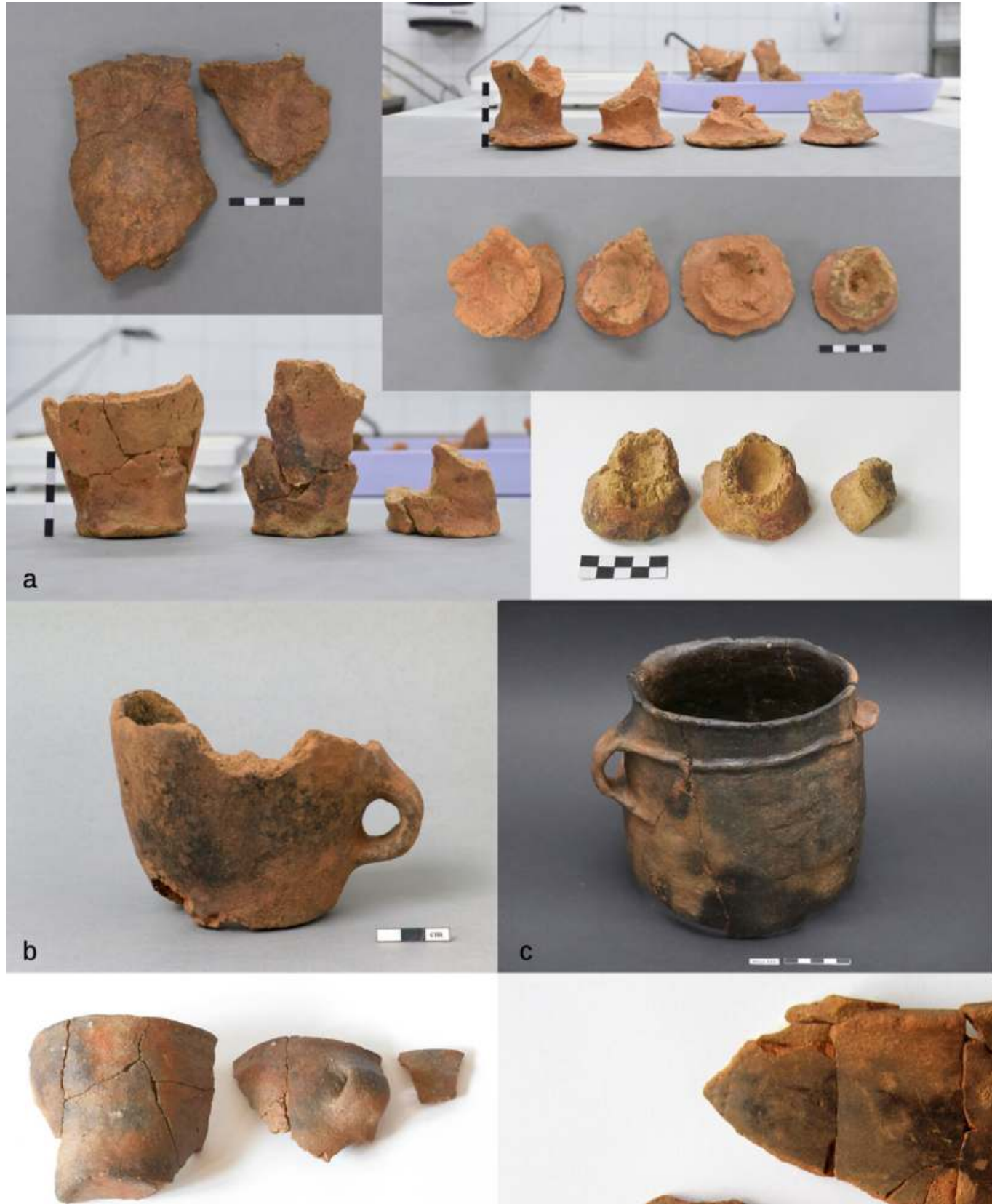

d
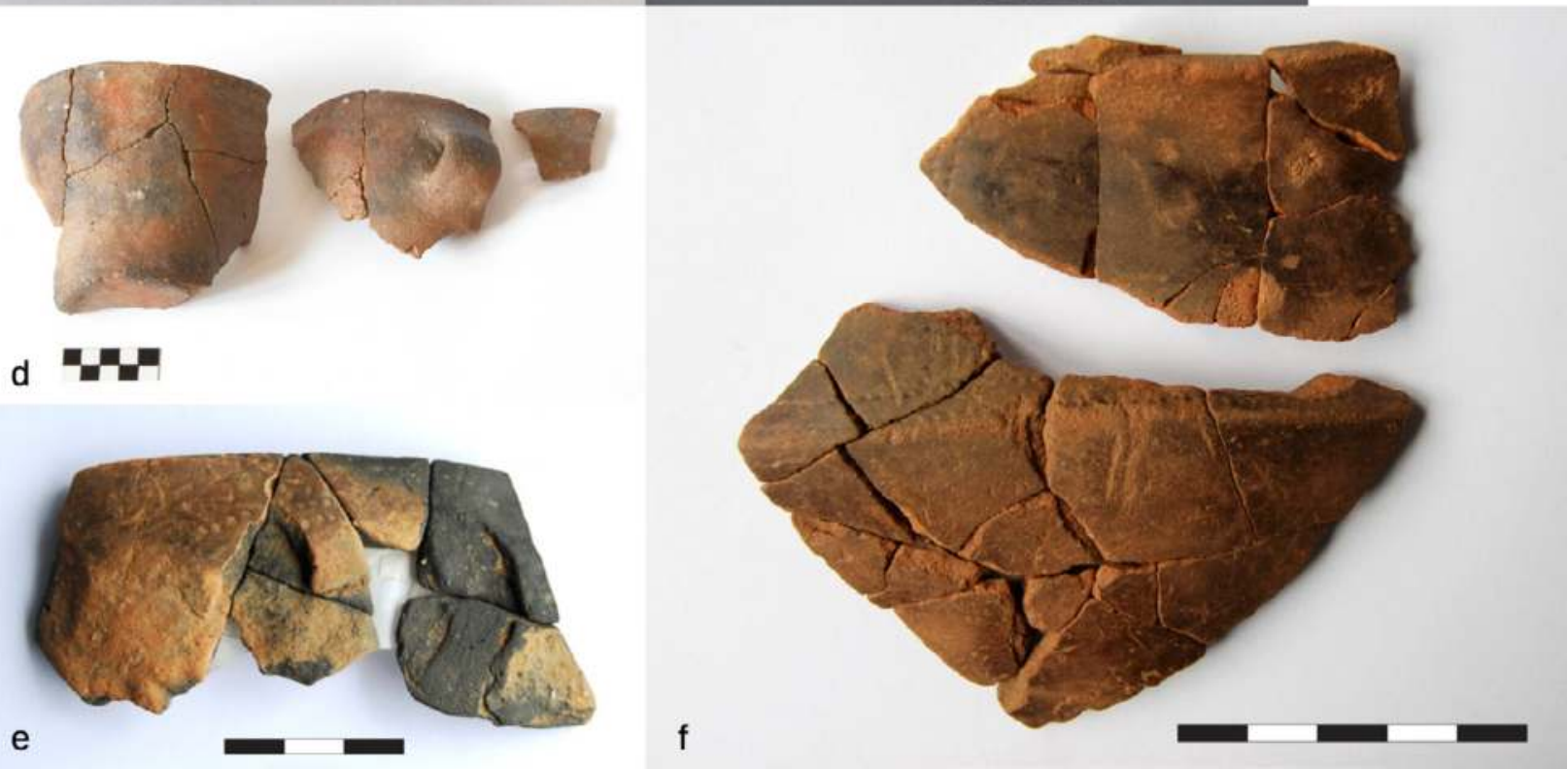

Figure 7. Some ceramic forms and decorations of Areias Altas I and II: (a) pedestal vessels; (b, d) tronco-conical forms; (c) subcylindrical form with plastic decoration; (e) possible semi-spherical bowl and (f) carinated bowl with burnished finish and comb-impression decoration (photos $b$ and $c$ by the Municipality of Porto). 
(Figure 7c). The vast majority of the ceramic pieces are connected to the pedestal vessels (Figure 7a), sometimes occurring in massive amounts (three pits had between 500-800 fragments, and one over 3000), being represented in most of the pits.

In addition to their shape, framed between conical and ovoid with pedestal base, a series of attributes make these vessels particularly distinctive. Overall, they have a rather crude character, strongly determined by their careless shaping, particularly evident on the rim fragments, which look 'unfinished', a coarse and crumbly texture with numerous inclusions, and while they appear to be poorly fired, it looks as though they have been subjected to high temperatures or thermal stress, given the presence of cracks and reddish/dark stains on the outer surface, which seem to result from shrinkage failures and specific exposure to combustion. Furthermore, the surface treatment appears to be uneven, since the external surfaces are always quite rough, while the internal ones exhibit traces of smoothing and greater care, particularly evident at the rims and bases.

The pedestal is the most paradigmatic fragment of Areias Altas, not only for its peculiar and often complete form, but also because it is the second most represented potsherd within the ceramic sample (6\%). These are solid pieces with slight variations in form and size, with dished or straighter sides and often with a widened base, featuring a concavity at the top (the vessel's bottom) where a clay coating is sometimes noticeable. In contrast, the rim fragments are quite scarce and difficult to identify, yet the few that remain internally preserved display a pattern of vertical grooves, likely to correspond to the marks left by a shaping tool, or even a mould (?).

Among the few decorated fragments the plastic decoration stands out (77\%), in the form of cordons, knobs and lugs, being connected with most of the pottery types, namely sub-cylindrical, ovoid, spherical and tronco-conical; the motifs are mostly horizontally arranged below the rim and may extend to the vessel's body, although more complex compositions occur. ${ }^{5}$

Second, there is a group related to incision (13\%, albeit half of them are interrogated), with simple motifs comprising horizontal, diagonal and triangular lines, for which it is not yet possible to establish a morphological correlation.

Finally, a group with what appears to be combimpression (9\%) should be highlighted. These are all

\footnotetext{
${ }^{5}$ As seems to be the case with a large ovoid vessel recovered at Areias Altas III that the present author had the opportunity to examine, where cordons and knobs resemble a garland-like composition.
}

fragments of carinated bowls and probably of semispherical form. They also stand out for matching the burnished finish of the fine ware, although they are quite worn and fragmented, hampering the identification of decorative schemes. In the semi-spherical form there is a motif diagonally arranged below the rim comprising three dotted lines: the top and bottom lines appear to be straight and parallel, while the middle one is more curved and attached to the top one; on the right, and with an opposite direction, a sequence of three points could give continuity to the composition (Figure 7e). The carinated bowls are mainly represented by fragments of the carination, featuring, immediately above or below it (depending on how we position the piece), two horizontal dotted lines. However, two refits probably from the same bowl and showing the rim, indicate a decorative panelled scheme: two horizontal dotted lines above the carination, and above these, two vertical dotted lines, one of which starts to curve below the rim, working as a separating motif between blank spaces, with a new sequence of dots at the right end being perceived (Figure 7f).

Returning to Russell Cortez's illustration (Figure 2), is it possible that some details could have been misinterpreted regarding this particular decoration on the carinated form? It seems that Cortez only had a carination fragment (left side of the drawing), but then, having decided to represent the complete vessel he depicted as a closed shape, with two lines below the carination apparently made through the repetition of a triangular (?) motif, perhaps more in line with puncturing technique. Yet the fragments we examined refer to an open shape with everted rim, and appear to have been decorated with a matrix of rounded edges (possibly a comb), stressing that this is the only case in which the piece's attitude is obvious, and all the motifs are above the carination.

Concerning ceramic chrono-typology, it should be noted that no parallels are known in Portugal, or in the Iberian Peninsula, for the predominant shape: the pedestal vessels. However, considering all their distinctive attributes, they seem to fit into a specific category of ceramic materials - briquetage (Gouletquer and Daire 1994; apud Terán 2011) - and the use of ceramic moulds to obtain 'salt cakes' through ignition, currently well-documented in European prehistory (Cassen and Weller 2013; Harding 2013; Weller 2002; 2015).

With this framework there are some peninsular contexts, highlighting a number of sites in central/ southern Portugal (Rocha 2013; Soares 2013; Soares and Silva 2013; Valera et al. 2006; Valera 2017), with a chronological range between 3700-2600 Cal BC (MidLate Neolithic/Early Chalcolithic), or Molino Sanchón 
II and Santioste (Abarquero et al. 2010; 2013), near Zamora, in Spain, dating from the mid 3rd to the early 2nd millennium BC (Late Chalcolithic/Early Bronze Age), the latter extending to the mid 2nd millennium BC (Middle Bronze Age) (Abarquero et al. 2017).

However, the pedestal fragments of Areias Altas find formal similarities with ceramic moulds from central and eastern Europe, notably with Bronze Age contexts in Poland (Harding 2013) and Chalcolithic in Romania (Sandu et al. 2012; Weller 2002; 2015), which, along with other evidence that will be further seen, strengthens their connection to salt production.

The remaining ceramic assemblage is well known in northern Portugal and surrounding regions, highlighting the presence of flat-based shapes, often with handles, of carinated bowls and the high percentage of plastic decoration. Flat-based shapes, along with carinated bowls, were interpreted by Susana Lopes as 'evolved' shapes 'indicating a new aesthetic that heralds the Bronze Age' (Jorge 1986: 622), becoming progressively more visible from the late 3rd/early 2 nd millennium onwards. This is particularly striking at long-term sites, such as Castelo Velho (Baptista 2003; Lopes 2019; Varela 2000), in the Upper Douro region, or in areas where it was possible to carry out comparative studies in diachrony, such as Chaves-Vila Pouca de Aguiar, in western Trás-os-Montes, with emphasis on the sites of Pastoria and Castelo de Aguiar (Jorge 1986), or Fornos de Algodres, in the Beira Alta region, and the sites of Malhada and Fraga da Pena (Valera 2007), where new morphologies, such as tronco-conical and carinated, often associated with plastic decoration, acquire great significance. ${ }^{6}$

In addition, tronco-conical vessels and carinated bowls are also frequently connected with funerary contexts, whether they are reuses of megalithic tombs or new kinds of structures, having a wide geographical distribution (Beira Alta, northern Portugal and Galicia) and chronological persistence (Jorge 1986; Bettencourt 1999), the former from the late 3rd millennium to the second quarter of the 2 nd millennium $\mathrm{BC}$, and the latter from the mid 2nd millennium to the 7th/6th century BC (Bettencourt 2010).

More challenging is to frame the presence of dotted impressions, with two possible scenarios emerging: the first focuses mainly on the decorative technique and the almost immediate reference to a Beaker background; the second pays particular attention to its occurrence in a carinated bowl with a decorative scheme comprising

\footnotetext{
6 "Although they never outweigh the local stylistic background, especially regarding the persistence of the high decoration percentage, which is particularly remarkable in the Trás-os-Montes region, but also at Castelo Velho.
}

blank and decorated panels, these being features that suggest affinity with the group of La Corvera/ El Tranco del Diablo, located in the southwest of the northern Spanish Meseta and considered one of the stylistic groups that gave rise to Cogotas I (Abarquero 2005; Fabián 2012). It is noteworthy that the Cogeces/ Protocogotas ceramics identified at the sites of Fraga dos Corvos (Luís 2016) and Castelo Velho (Pereira 1999) also seem to find inspiration in La Corvera/El Tranco del Diablo and in the neighbouring group of Valle Amblés/Valle del Duero (Fabián 2012). Both scenarios are still precarious, and therefore daring, with the first documenting the persistence of a Beaker tradition well into the 2nd millennium BC in northern Portugal, and the second the extension of the Cogotas I influence up to the mouth of the Douro River.

\section{Lithic materials}

The lithic assemblage recovered at Areias Altas I and II $(\mathrm{N}=1845)$ is dominated by local raw materials in which quartzite predominates (55\%), and granite, quartz, shale, and others (undetermined) are also present. Since the very beginning of the field work, three major characteristics have stood out in the assemblage composition: the strong presence of macrolithic industries on pebble and flake; a smaller, but no less important, quartz industry; and a high number of stones with evidence of thermal alteration. These evidences could be of different kinds, such as deep surface cracks, fine crazing, colour changes (discolouration, reddening, sooting), and patterned fractures. Furthermore, during material analysis it became clear that whenever a tool or a stone with use-wear simultaneously exhibited traces of thermal alteration, these referred to the last event of their history (and not the other way round). In this sense, it was intended, whenever possible, to value their 'life history' and not only their first purpose.

Therefore, from the typological point of view it was found that lithics with thermal alteration represent the largest percentage of the whole (65\%); the vast majority exhibit no other features (57\%) and may correspond to the remains of hearths and combustion structures, which is particularly evident on burnt blocks and slabs on one side only; however, the identification of several cases with previous uses is noteworthy, mostly knapped pebbles (4\%), knapped stone tools and grinding stones (around 2\% each), and if it is possible that some have been simply too close to fire, their integration into combustion structures should not be overlooked; several refits were also achieved, though most of all within the same pits (Figure 8a-d).

There is also a significant amount of lithic material with apparently no signs of use (16\%), which can be interpreted as discarded raw material that was never 


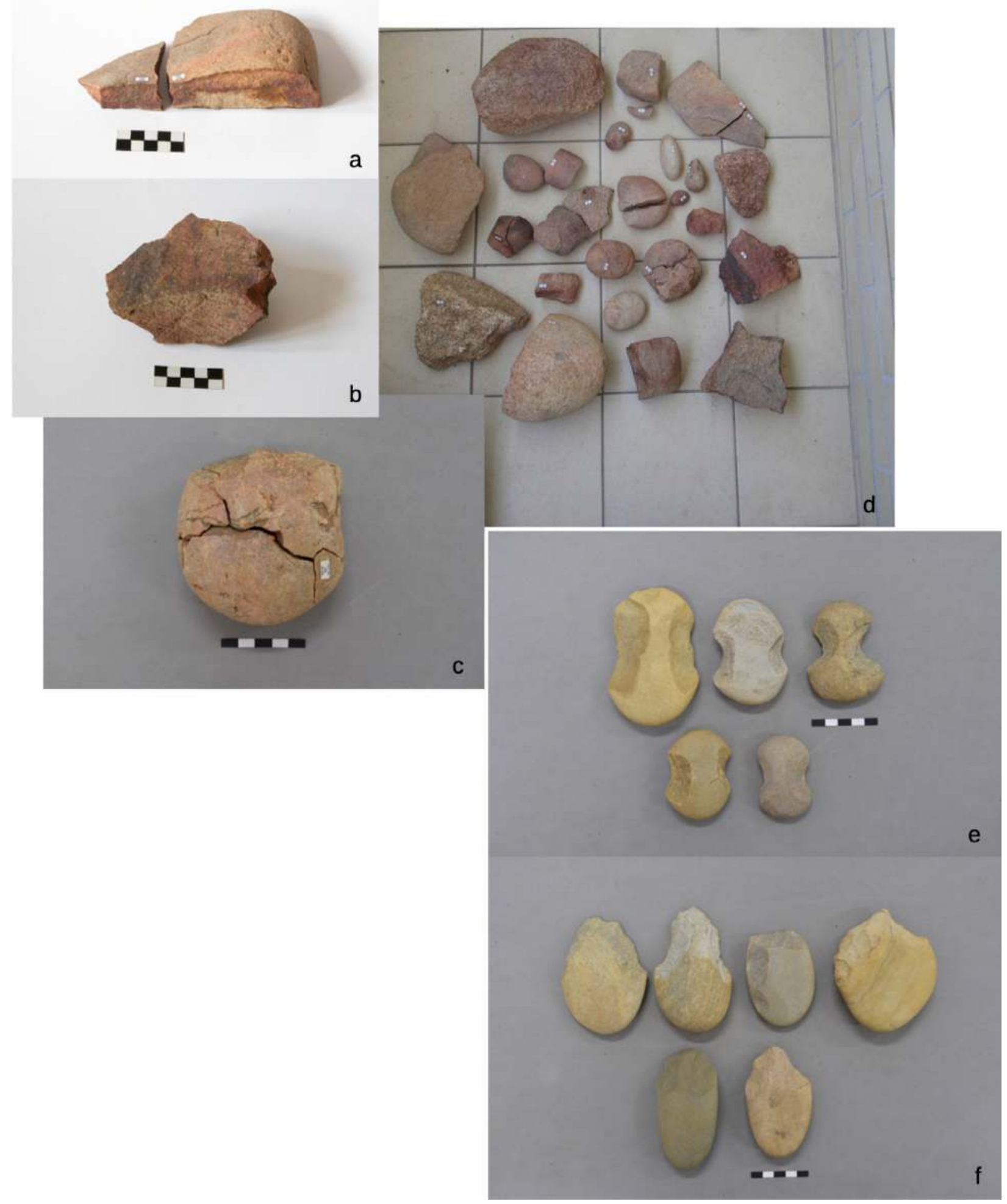

Figure 8. (a-d) Lithic assemblage with evidence of thermal alteration recovered from a fill of Structure 15 at Areias Altas I: (a) a refit with no other evidence; (b) a grinding stone; (c) a refit of a knapped pebble; and (d) the complete assemblage. (e) Fishing net weights. (f) Different kinds of knapped pebbles (photo (d) by Cláudia Manuel). 
used, or whose contribution in the creation of contexts and their meanings may be as relevant as that of artefacts. The remaining assemblage is found to have a certain balance regarding the distribution of knapped stone tools (6\%), flakes (5\%, over half with retouches and use-wear), and knapped pebbles (4\%). Among the knapped stone tools, quartzite net weights stand out (Figure 8e), but scrapers, notches and denticulates are also present. The group of knapped pebbles mostly comprises distal unifaces of pointed outline (Figure 8f), often with use traces, with several examples where the proximal edge was also used as a hammer; the occasional presence of pebble artefacts with patinas that refer to a greater antiquity is also remarkable, namely a specimen with double patina (i.e. with a fresh edge and an eolised one).

The less significant amount of lithics includes working debris, cores, hammers and grinding stones; to a certain extent, the latter can be interpreted as tools for processing food or other goods in general, and not necessarily cereals, as Russell Cortez pointed out and is commonly accepted, since so far there is no such evidence. Moreover, the presence of a polished stone tool is noteworthy and may be related to wood supply, either for building structures or as fuel, with several species having been documented. ${ }^{7}$ The fact that it is fragmented and made from an exogenous raw material (amphibolite) may also be relevant, as people could have taken whole tools elsewhere (Garrow et al. 2005: 145-146).

Overall, two points should be emphasised. First of all, the lithic industry is dominated by the presence of techniques and artefacts of great antiquity and lifespan, which have on the northern coast of Portugal, and in Porto particularly, a great tradition (Meireles 1992; 2009; Monteiro-Rodrigues 2000). These are often considered archaic tools, as they do not require very sophisticated technical skills, and perhaps this is one of the keys to their longevity, along with their availability in nature. In addition, versatility is one of their greatest attributes, unfolding into different categories and cumulating multiple functions in the same artefact.

The second point to emphasise is that the high number of thermo-altered lithics suggests the existence of intense fire-related activities. In fact, it often seems that there were hearths inside the pits, no longer in the physical and structural sense, but as a reminiscence,

\footnotetext{
The following taxa were identified from soil samples: Quercus $s p$. Caducifolio; Frangula alnus; Monocotyledons; Fabaceae; Corylus avellana; Pinus sp. and undetermined. Regarding their combustible qualities, it should be noted that Quercus and Fabaceae are recognised for producing long-lasting embers, while Corylus and Pinus generate faster combustion, the latter producing more flame. The anthracological study is being carried out by Maria Martín Seijo, whom I would like to thank for providing the data.
}

i.e. those hearths or combustion structures actually existed in physical and temporal spaces other than the pits. But what kind of scenario could be behind all this evidence? For a long time this was an intriguing question, considering that the material culture within the pits was telling much more about everyday life than about occasional or unusual activities. In fact, the answer could be associated with the other striking evidence of Areias Altas, that of pedestal vessels and their specific use, as crystallisers and moulds, in the production of salt by artificial evaporation.

\section{Shell assemblages}

Shell assemblages have been recovered from all interventions, with a greater occurrence at Areias Altas II within four pits. They usually appear in the form of small mounds occupying the pit centres, except for Structure 66 at Areias Altas II, where a mixture of shells, ceramic fragments and soil surrounded the pit sides, in association with an almost complete pot (only the base was missing) that also contained shells (Figure 7c).

This structure, and Structure 15 from Areias Altas I (Figure 6b-c), stand out for several reasons: they represent two of the singular contexts that allowed structured depositions to be considered (Luz 2010); they included the most impressive amount of molluscs; the unusual occurrence of marine elements in the archaeological record of northern Portugal aroused other scientific interests, namely their biological study (Cabral 2010; 2014) and their dating.

Overall, the shells were very well-preserved and both assemblages were dominated by limpet specimens. In Structure 15 (Cabral 2010) at least three different limpet species were identified, some snails, mussel valves and barnacle remains (referred to as inedible). Their good preservation was assigned to the neutral pH of the soil, which is contrary to most of the Portuguese north-west region, known for its acidity; this also suggested that the specimens were collected alive, probably from the rocky beaches near the archaeological site.

Cabral focused on limpets and compared them with specimens collected on beaches north of Porto. Small,yet significant morphometric differences were observed, interpreted as resulting from different environmental conditions than we have today. The possibility of nonselective collection (suggested by size randomness and the presence of barnacles) was highlighted, leading to the view that the food need was not acute, or pressing, and that molluscs would possibly play a secondary/ residual role in the diet, integrating other livelihood resources such as fishing and/or agriculture.

Here we may add the archaeological view of the context and the possibility of shells embodying a meaning that 
Table 1: Radiocarbon dates for two pits from Areias Altas I and II. Calibration based on the Marine 13 curve (Reimer et al. 2013) using the OxCal 4.3.2 program (Bronk Ramsey 2017). The marine reservoir effect for the Portuguese western coast was taken into account $\left(\Delta \mathrm{R}=95 \pm 15{ }^{14} \mathrm{C}\right.$ years) (Soares and Dias 2006).

\begin{tabular}{|c|c|c|c|c|c|c|}
\hline Area & Structure & Lab. No. & Sample & Radiocarbon Age BP & Cal BC $1 \sigma(68.2 \%)$ & Cal BC $2 \sigma(95.4 \%)$ \\
\hline \multirow[t]{2}{*}{ Areias Altas I } & \multirow[t]{2}{*}{15} & Sac-2474 & Patella sp & $3820 \pm 45$ & $1761-1622$ & 1861-1574 \\
\hline & & Sac-2475 & Mytilus sp & $3800 \pm 50$ & $1746-1601$ & 1841-1527 \\
\hline \multirow[t]{3}{*}{ Areias Altas II } & \multirow[t]{3}{*}{66} & Beta-347887 & Shell & $3790 \pm 30$ & $1713-1612$ & 1764-1549 \\
\hline & & Beta-347888 & Shell & $3830 \pm 30$ & $1758-1650$ & $1841-1611$ \\
\hline & & Beta-347889 & Shell & $3780 \pm 30$ & $1699-1598$ & $1747-1537$ \\
\hline
\end{tabular}

is beyond purely a means of subsistence. Ultimately, one question remains open: were they eaten at all?

In Structure 66, Cabral (2014) gave particular attention to a snail species which had two morphological features that immediately stood out: the apex preservation and the prominence of the umbilicus were very different from the modern specimens known in the Porto region. Comparison was then made with specimens collected along the Portuguese mainland coast, challenging these particular features and their possible environmental significance. It was found that the apex preservation had a relation to latitude, improving considerably from the central coast and particularly evident on the southern coast of Algarve; this relationship allows the suggestion that the seashore in the area of Areias Altas would be less exposed, with less sea disturbance and lower wave intensity than at present.

It was also found that the sizes of the archaeological specimens were larger than most of today's. Moreover, the specimens inside the vessel were larger than those outside, which led Cabral to consider the possibility of an intentional selection, in line with the archaeological interpretation of a deliberate deposition of this context.

\section{Site chronology}

The dated samples resulted from an opportunity to date first the archaeological marine elements, and then those particular shell assemblages. Nevertheless, it was hoped that the results would provide some interpretative margin in view of the differences observed between the two areas in terms of density, morphology, and pit size. However, the ranges obtained are quite consistent, roughly falling between 1800-1500 cal $B C$, i.e. in the first half of the 2nd millennium BC.

According to the periodisation established by Bettencourt $(2010$; 2013) for the Portuguese northwest, this timespan places the occupation of the site between the last stage of the Early Bronze (2300/2200 $\mathrm{BC}-1700 / 1600 \mathrm{BC})$ and the dawn of the Middle Bronze Age $(1700 / 1600-1100 / 1000$ BC)
There is no intention to discuss periodisation in this work, and perhaps it may be more fruitful to look for evidence that can contribute instead to discuss the temporality of occupation at Areias Altas. In this sense, the occurrence of negative features on an essentially horizontal stratigraphy and the identification of a pit at the top a colluvial deposit, can be a start. Rather than considering the existence of two levels of occupation, it opens the possibility that this structure refers only to a distinct episode among others covered by such formation.

\section{Final considerations}

In between Cortez's discovery and the preventive archaeological work, there is a gap of several decades which is reflected in the results exposed from all points of view, although the author has identified several aspects that remain current and that are determinant in the characterisation of the site. It is clear that the image presented is still rather fragmented and incomplete. But briefly, it may be claimed that a new pit site has been rediscovered - one that has since come to fill a singular space in the context of the first half of the 2nd millennium BC of northern Portugal.

In terms of location, the coastal platform, there are only two other pit sites, north of Areias Altas, with approximate dates (mid 2nd millennium BC): the sites of Lavra (Matosinhos) (Bettencourt and Fonseca 2011) and Corgo (Vila do Conde) (Botelho 2016). They also have some materials in common, such as flat-bottom ceramics with plastic decorations, and lithic industries on quartzite pebbles, but these are features shared by many other sites and within a much broader chronology.

If we are looking for more detail, what really distinguishes the site of Areias Altas relies fundamentally on two possibilities: deposition practices and salt production.

The subject of depositions in the Bronze Age remains, mainly in the north of Portugal, virtually limited to two types of archaeological expressions: metal hoards and funerary contexts. Although in recent decades there has been an increased interest by Portuguese archaeologists in this subject and an effort to discuss 


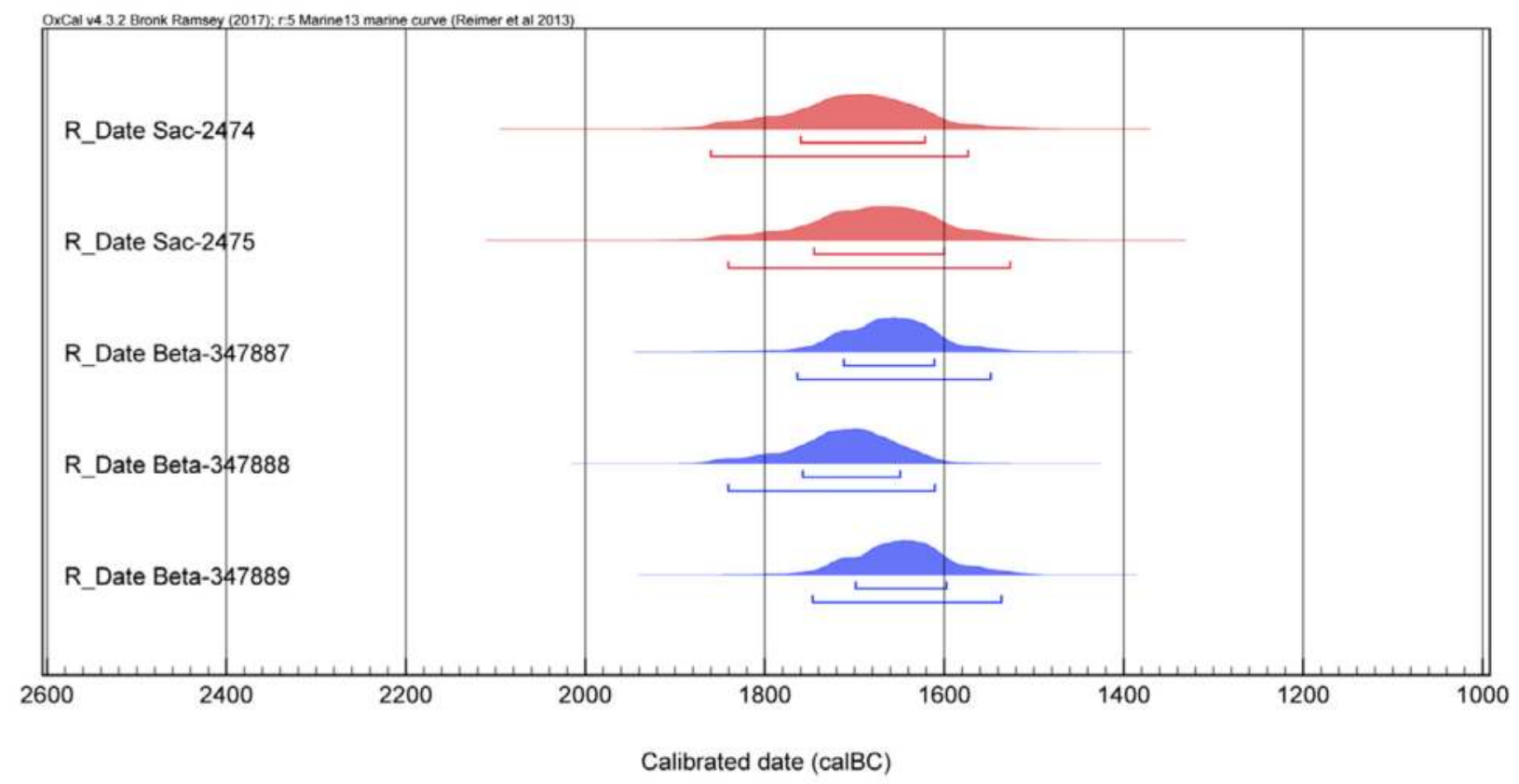

Figure 9. Graphical representation of the probability distributions of the radiocarbon dates.

it (Valera 2019), it seems important to insist on this debate, otherwise we will miss an important social dimension of prehistoric communities.

Research on pre-historic salt production in Portugal is another fairly recent theme, being well-documented only in the central/south and covering earlier chronologies. In the north, there is some evidence, mostly out of context, highlighting a fragmented shale salt pan found at Carreço beach (Viana do Castelo) (Meireles 1992; Bettencourt 2009) and dated from the Early Bronze Age, in addition to the thinking that the north-west coast would be conducive to salt exploitation during the Bronze Age (Bettencourt 1999). In this sense, the evidence that refers to salt production at Areias Altas - the pedestal vessels possibly used as crystallisers and moulds for 'salt cakes', and the remains of combustion structures - are unprecedented. This requires reflection in order to understand the techniques involved and the social context behind this practice.

The pits fills also gave a glimpse of a daily life beyond salt production. Fishing and mollusc gathering, attested by dozens of net weights and shell deposits, seem to have been important activities in which people were also engaged; on the other hand, so far there is not much evidence that agriculture was practised.

With this text, the intention was to demonstrate that our current knowledge on the site of Areias Altas is diametrically larger. And that this breadth seems to encapsulate an exponential quality, allowing us to explore various aspects that should not only contribute to our understanding of the site itself, but also its place within the first half of the 2nd millennium BC.

\section{Acknowledgements}

I would like to thank Susana Lopes and Sérgio Gomes for inviting me to the seminar, and for the suggestions they made throughout the writing of this text. Thanks also go to António Monge Soares for his readiness to review the calibration of absolute dates. In addition, I am grateful to the reviewer of this text for the relevant and constructive comments.

\section{References}

Abarquero Moras, F.J. 2005. Cogotas I. La difusión de un tipo cerámico durante la Edad del Bronce. Arqueología en Castilla y Léon (Monografias 4). Valladolid: Junta de Castilla y Léon.

Abarquero Moras F.J, Guerra Doce, E., Delibes de Castro, G., Palomino Lázaro, A.L. and Del Val Recio, J. 2010. Excaviones en los 'cocederos' de sal prehistóricos de Molino Sanchón II y Santioste (Villafáfila, Zamora), in F.J. Abarquero Moras and E. Guerra Doce (eds) Los yacimientos de Villafáfila (Zamora) en el marco de las explotaciones salineras de la prehistoria europea: 85-118. Valladolid: Junta de Castilla y Léon.

Abarquero Moras F.J, Guerra Doce, E., Delibes de Castro, G., Palomino Lázaro, A.L. and Del Val Recio, J. 2013. Explorações pré-históricas de sal nos arredores das lagunas de Villafáfila (Zamora, Espanha), in J. Soares (ed) Prehistory of wetlands. Ladscapes of salt: 233-254. Setúbal Arqueológica 14. Setúbal: MAEDS. 
Abarquero Moras, F.J., Guerra Doce, E., Delibes de Castro, G. and López Sáez, J.A. 2017. La explotación de la sal durante la Prehistoria en las Lagunas de Villafáfila (Zamora): los cocederos de Molino Sanchón II y Santioste. Cuaternario y Geomorfología 31 (1-2): 7-24. https://doi.org/10.17735/cyg.v31i1-2.53646.

Araújo, M.A. 1991. Evolução geomorfológica da plataforma litoral da região do Porto. Unpublished $\mathrm{PhD}$ dissertation, University of Porto.

Baptista, L. 2003. A cerâmica do interior do recinto de Castelo Velho de Freixo de Numão. Contributos para a interpretação de contextos de uso. Unpublished Master's dissertation, University of Porto.

Bettencourt, A.M.S. 1995. Dos inícios aos finais da Idade do Bronze no Norte de Portugal, in I. Silva and I. Cordeiro (eds) A Idade do Bronze em Portugal. Dicursos de Poder: 110-115. Lisboa: Instituto Português dos Museus, Museu Nacional de Arqueologia.

Bettencourt, A.M.S. 1999. A Paisagem e o Homem na bacia do Cávado durante o II e I milénios AC. Unpublished PhD dissertation, University of Minho.

Bettencourt, A.M.S. 2009. A Pré-história do Minho: do Neolítico à Idade do Bronze, in P. Pereira (ed) Minho. Traços de Identidade: 70-113. Braga: Conselho Cultural da Universidade do Minho.

Bettencourt, A.M.S. 2010. La Edad del Bronce en el Noroeste de la Península Ibérica: una análisis a partir de las prácticas funerárias. Trabajos de Prehistoria 67(1): 139-173.

Bettencourt, A.M.S. 2013. A Pré-história do Noroeste Português/The Prehistory of North-Western Portugal, in Territórios da Pré-história em Portugal, vol. 2. Braga/Tomar: CEIPHAR/CITCEM (E. biligue).

Bettencourt, A.M.S and Fonseca, Jorge 2011. O povoado da Idade do Bronze de Lavra, Matosinhos. Contributos para o estudo do Bronze Médio no litoral Norte. Braga: J.F Lavra/C.M.Matosinhos/CITCEM.

Botelho, I. 2016. O processo do Corgo. Do princípio da conservação pelo registo científico. Unpublished $\mathrm{PhD}$ dissertation, University of Porto.

Bronk Ramsey, C. 2017. Methods for Summarizing Radiocarbon Datasets. Radiocarbon 59 (2): 1809-1833.

Cabral, J.P. 2010. O depósito de conchas do sítio arqueológico das 'Areias Altas' (Porto, Portugal). Estudo morfológico e morfométrico das conchas inteiras de moluscos, in E.G. Gómez, V.B García, C.F. Rodríguez and N.F. Prieto (eds) I Reunión Científica de Arqueomalacología de la Península Ibérica: 73-82. Férvedes 6. Villalba: MPAV.

Cabral, J.P. 2014. Morfologia das conchas de Phorcus Lineatus (da Costa 1778: Trochus) do sítio arqueológico de Areias Altas II (Porto, Portugal) e seu possível significado ambiental, in J.J. Cantillo, D. Bernal and J. Ramos (eds) Moluscos y púrpura en contextos arqueológicos atlántico-mediterráneos. Actas de la III Reunión Científica de Arqueomalacología de la
Península Ibérica: 65-73. Cádiz: Universidad de Cádiz, Servicio de Publicaciones.

Cassen, S. and Weller, O. 2013. Idées et faites relatifs à la production de sels marins et terrestres en Europe, du VIe au IIIe millénnaire, in J. Soares (ed.) Prehistory of wetlands. Ladscapes of salt: 255-304. Setúbal Arqueológica 14. Setúbal: MAEDS.

Cortez, F.R. 1952. Contributos para o estudo do Neolítico de Portugal. Trabalhos de Antropologia e Etnologia 13(3-4): 193-248. Porto: SPAE.

Cortez, F.R. 1984. Achados Pré-históricos na área do Porto. Arqueologia 10: 11-12. Porto: GEAP.

Fabián García, J.F. 2012. Proto-cogotas I en el suroeste de la Meseta Norte. Dos facies alfareras en territorios inmediatos, in J.A. Rodríguez Marcos and J. Fernandez Manzano (eds) Cogotas I. Una cultura de la Edad del Bronce en la Península Ibérica: 323-348. Valladolid: Universidad de Valladolid.

Garrow, D., Beadsmoore, E. and Knight, M. 2005. Pit clusters and the temporality of occupation: an Earlier Neolithic site at Kilverstone, Thetford, Norfolk. Proceedings of the Prehistoric Society 71: 139157.

Harding, A. 2013. Salt in Prehistoric Europe. Leiden: Sidestone Press.

Jorge, S.O. 1986. Povoados da Pré-história Recente (III Inícios do II ${ }^{2}$ Milénios A.C.) da região de Chaves - Vila Pouca de Aguiar (Trás-os-Montes Ocidental). Porto: Instituto de Arqueologia da Faculdade de Letras.

Lopes, S.S. 2019. Voltar a Castelo Velho de Freixo de Numão: pensar a reconfiguração dum recinto pré-histórico do Alto Douro português, in Olhares sobre Castelo Velho de Freixo de Numão: revisitar um recinto pré-histórico do Alto Douro português: 357-389. Coimbra: DigitAR Monografias.

Luís, E. 2016. Mudança e transformação. Calcolítico, Bronze Inicial e Bronze Médio em Trás-os-Montes Oriental: reflexões a partir dos recipientescerâmicos. Unpublished $\mathrm{PhD}$ dissertation, Unviversity of Lisbon.

Luz, S. 2010. O depósito de conchas do sítio arqueológico das Areias Altas (Porto, Portugal). Discussão do enquadramento arqueológico da Estrutura 15, in E.G. Gómez, V.B. García, C.F. Rodríguez and N.F. Prieto (eds) I Reunión Científica de Arqueomalacología de la Península Ibérica: 141-145. Férvedes 6. Villalba: MPAV.

Meireles,J.1992. Asindústrias líticas pré-históricas do litoral minhoto. Contexto cronoestratigráfico e paleoambiental. Cadernos de Arqueologia (Monografias 7). Braga: Universidade do Minho.

Meireles, J. 2009. Os primeiros povoadores. A Préhistória Antiga do Minho, in P. Pereira (ed.) Minho. Traços de identidade: 20-66. Braga: Conselho Cultural da Universidade do Minho.

Monteiro-Rodrigues, S. 2000. A Pré-história Antiga da região do Porto: síntese bibliográfica. Al-Madan 9 (2 $2^{\mathrm{a}}$ série): 74-78. Centro de Arqueologia de Almada. 
Pereira, L. 1999. As cerâmicas 'Cogeces' de Castelo Velho, Freixo de Numão (Vila Nova de Foz Côa). Seu enquadramento peninsular. Unpublished Master's dissertation, University of Porto.

Reimer, P.J., Bard, E., Bayliss, A., Beck, J.W., Blackwell, P.G., Bronk Ramsey, C., Buck, C.E., Cheng, H., Edwards, R.L., Friederich, M., Grootes, P.M., Guilderson, T.P., Haflidason, H., Hadjas, I., Hatté, C., Heaton, T.J., Hoffman, D.L., Hogg, A.G., Hughen, K.A., Kaiser, K.F., Kromer, B., Manning, S.W., Niu, M., Reimer, R.W., Richards, D.A., Scott, E.M., Southon, J.R., Staff, R.A., Turney, C.S.M., Van der Plicht, J. 2013. IntCal13 and Marine13 Radiocarbon Age Calibration Curves, 0-50,000 Years cal BP. Radiocarbon 55(4): 1869-1887.

Rocha, L. 2013. A praia do Forte Novo. Um sítio de produção de sal na costa Algarvia?, in J. Soares (ed) Prehistory of wetlands. Ladscapes of salt: 225-232. Setúbal Arqueológica 14. Setúbal: MAEDS.

Sanches, M.J. 1980. Alguns vasos cerâmicos inéditos do Museu de Antropologia do Porto. Arqueologia 1: 1219. Porto: GEAP.

Sanches, M.J. 1981. Recipientes cerâmicos da Préhistória recente do Norte de Portugal. Arqueologia 3: 88-97. Porto: GEAP.

Sandu, I., Weller, O., Stumbea, D. and Alexianu, M. 2012. Analyses archéométriques sur les moules à sel chalcolithiques de l'est de la Roumanie, in V. Nikolov and K. Bacvarov (eds) Salt and gold: the role of salt in Prehistoric Europe: 143-154. Provadia: Faber.

Soares, A.M.M. and Dias, J.M.A. 2006. Coastal Upwelling and Radiocarbon - Evidence for Temporal Fluctuations in Ocean Reservoir Effect off Portugal during the Holocene. Radiocarbon 48(1): 45-60.

Soares, J. 2013. Sal e conchas na Pré-história portuguesa. O povoado da Ponta da Passadeira (estuário do Tejo), in J. Soares (ed) Prehistory of wetlands. Ladscapes of salt: 171-196. Setúbal Arqueológica 14. Setúbal: MAEDS.

Soares, J. and Silva, C.T. 2013. Economia agro-marítima na Pré-história do estuário do Sado. Novos dados sobre o Neolítico da Comporta, in J. Soares (ed.) Prehistory of wetlands. Landscapes of salt: 145-170. Setúbal Arqueológica 14. Setúbal: MAEDS.
Terán Manrique, J. 2011. La producción de sal en la Prehistoria de la Península Ibérica: estado de la questión. Arqueología y Territorio 8: 71-84. http:// www.ugr.es/ arqueologyterritorio/Index.htm, viewed 13 March 2020

Valera, A.C. 2007. Dinâmicas locais de identidade: estruturação de um espaço de tradição no $3^{\circ}$ milénio AC (Fornos de Algodres, Guarda). Braga: C.M. Fornos de Algodres/TA.

Valera, A.C. 2017. Salt in the 4th and 3rd millennia BC in Portugal: specialization, distribution and consumption. Cuaternario y Geomorfología 31 (12): 105-122. https://doi.org/10.17735/cyg.v31i12.53656 .

Valera, A.C. (ed.) 2019. Fragmentation and depositions in Pre and Proto-historic Portugal. Lisboa: NIA, Era Arqueologia S.A.

Valera, A.C., Tereso, J.P. and Rebuge, J. 2006. O Monte da Quinta 2 (Benavente) e a produção de sal no Neolítico Final/Calcolítico do estuário do Tejo, in N. Bicho and H. Veríssimo (eds) Do Epipaleolítico ao Calcolítico na Península Ibérica. Actas do IV Congresso de Arqueologia Peninsular: 201-305. Promontoria Monográfica 4. Faro: Universidade do Algarve.

Varela, J.M. 2000. As cerâmicas do Bronze Inicial e Médio de Castelo Velho de Freixo de Numão (Vila Nova de Foz Côa). Tradição e inovação na transição do III $I^{\circ}$ para o IIํ milénio AC. Unpublished Master's dissertation, University of Porto.

Weller, O. 2002. Aux origines de la production du sel en Europe. Vestiges, fonctions et enjeux archéologiques, in O. Weller (ed) Archéologie du sel. Techniques et sociétés. Actes du Colloque 12.2 du XIVe Congrès UISPP, 4 septembre 2001, et de la Table Ronde du Comité des Salines de France, 19 mai 1998, Paris: 163-175. ASTK 3. Rahden: Marie Leidorf GmbH, Internationale Archäologie.

Weller, O. 2015. First salt making in Europe: an overview since Neolithic times. Documenta Praehistorica LXII: 185-196. https://doi.org/10.4312/dp.42.12. 


\title{
Chapter 5
}

\section{Searching for the Turning Point to Bronze Age Societies in Southern Portugal: Topics For A Debate}

\author{
Joaquina Soares \\ MAEDS/AMRS - Museum of Archaeology and Ethnography of the District of Setúbal and UNIARQ- \\ Centre of Archaeology of the University of Lisbon
}

\begin{abstract}
This contribution aims to address the Chalcolithic/Bronze Age transition in southern Portugal from a socio-economic perspective. The starting point is the extensive archaeological fieldwork that took place at the Chalcolithic fortification of Porto das Carretas (Luz Territory) on the left bank of the Middle Guadiana river, integrated in multi-geographical scales. Our main goal is to arrive 'just in time' at the dawn of southwest Middle Bronze Age societies, trying to understand their formation. In chronological terms, the deconstruction of Chalcolithic societies began in central-southern Portugal around 2500 cal BC, coincident with the rise of the Bell Beaker phenomenon. At Chibanes (Estremadura), domestic architectures and the wall of the fortification were damaged, with no signs of any reconstruction. Other sites, such as Porto das Carretas and Monte da Tumba (Alentejo) had been rebuilt by Bell Beaker elites, showing a clear cut with the previous architectural programs. Ditched enclosures collapsed c. 2200-2000 cal BC, but the construction of the latest ditches of the enclosure systems did not extend beyond 2500$2400 \mathrm{cal}$ BC. The construction of large tholos-type collective funerary monuments was replaced by individual graves, although sometimes with the reuse of the previous collective tombs. This trend to single graves reached a peak in the Early/Middle Bronze Age. The crisis of the Chalcolithic society and its collapse in the second half of the 3rd millennium cal BC allowed more unequal and hierarchical regional Bronze Age societies throughout southern Iberia, along with craft specialisation/oriented groups (socio-economic specialisation of labour) in metallurgy and textile activities (mainly linen production). At the same time, the political economy grew more differentiated, controlled by powerful chiefs of the 'Southwest Bronze Age Culture', or ruled by the early state of El Argar in the southeast.
\end{abstract}

Keywords: Chalcolithic, Bell Beaker, Early Bronze Age, 'Southwest Bronze Age Culture', Porto das Carretas.

\section{Introduction: dealing with the data}

Around 2200 cal BC, the old kinship social-organisation inspired by long-lasting communal principles, inherited from Neolithic 'egalitarian' societies, collapsed, not necessarily by the effect of the $4.2 \mathrm{Ky} \mathrm{BP}$ event (Meller et al. 2015; Risch et al. 2015; Blanco-González et al. 2018), but rather by socio-economic dynamics (Figure 1). Environmental conditions obviously played a meaningful role, although these have not yet been satisfactory evaluated. A new world emerged, with increasing social complexity, a strong sphere of political economy, wider territorial scales of political organisation, and networks of unequal exchange (Soares 2016; 2017; Bueno Ramirez, Balbín Behrmann and Barroso Bermejo 2005; Bueno Ramírez et al. 2019). In southern Iberia, the first state emerged at El Argar around 2200-2000 BC (Lull et al. 2015) and the weak development or even crisis of the peripheral southwestern societies of the Early Bronze Age (EBA) could not be explained without stressing their geopolitical position on the edges of the Argaric core (Figure 9) (Soares and Tavares da Silva 1998; 2016).

Over the last decades, the empirical record has grown exponentially, with no precedents in the south of the Iberian Peninsula, due to the development of rescue archaeology as a response to accelerated urban growth and to the construction of major public infrastructures, such as the irrigation system of the Alqueva Dam in the Guadiana Basin. Despite the great accumulation of fieldwork data, there are weaknesses and lacunae in its study.

It was a period when archaeological sciences (archaeometry) were becoming increasingly more important (Martinón-Torres and Killick 2015), mainly in the domains of stable isotope analysis (Díaz-Zorita 2017; Waterman, Tykot and Silva 2015; Waterman et al. 2013), and genetic studies (Olalde et al. 2018; 2019), but these were instrumental and in need of integration, with clarity, in archaeological theories (scientific archaeology rooted in natural and social sciences), avoiding those archaeometry practices addressed to meaningless subjects - or just to technicalities not well contextualised in the archaeological entities. Nowadays, many young scholars are being trained in both archaeological theory and in scientific analysis, and they can be the future bridges to link 'field and lab' archaeologies.

The genetic data is being analysed mostly through 'new diffusionist' approaches, perhaps inspired by the current migration catastrophe, with such outstanding 


\section{GENERAL CONCEPTS}

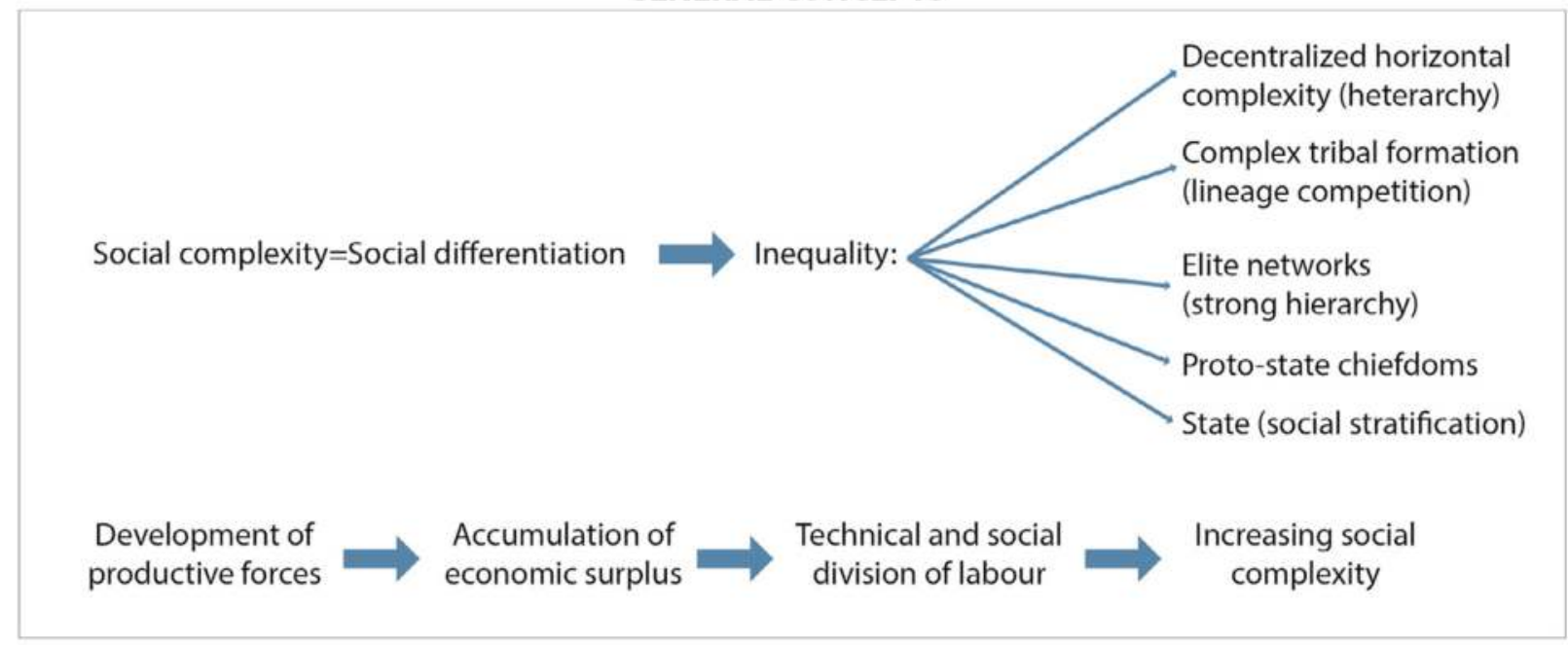

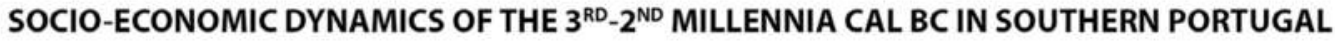

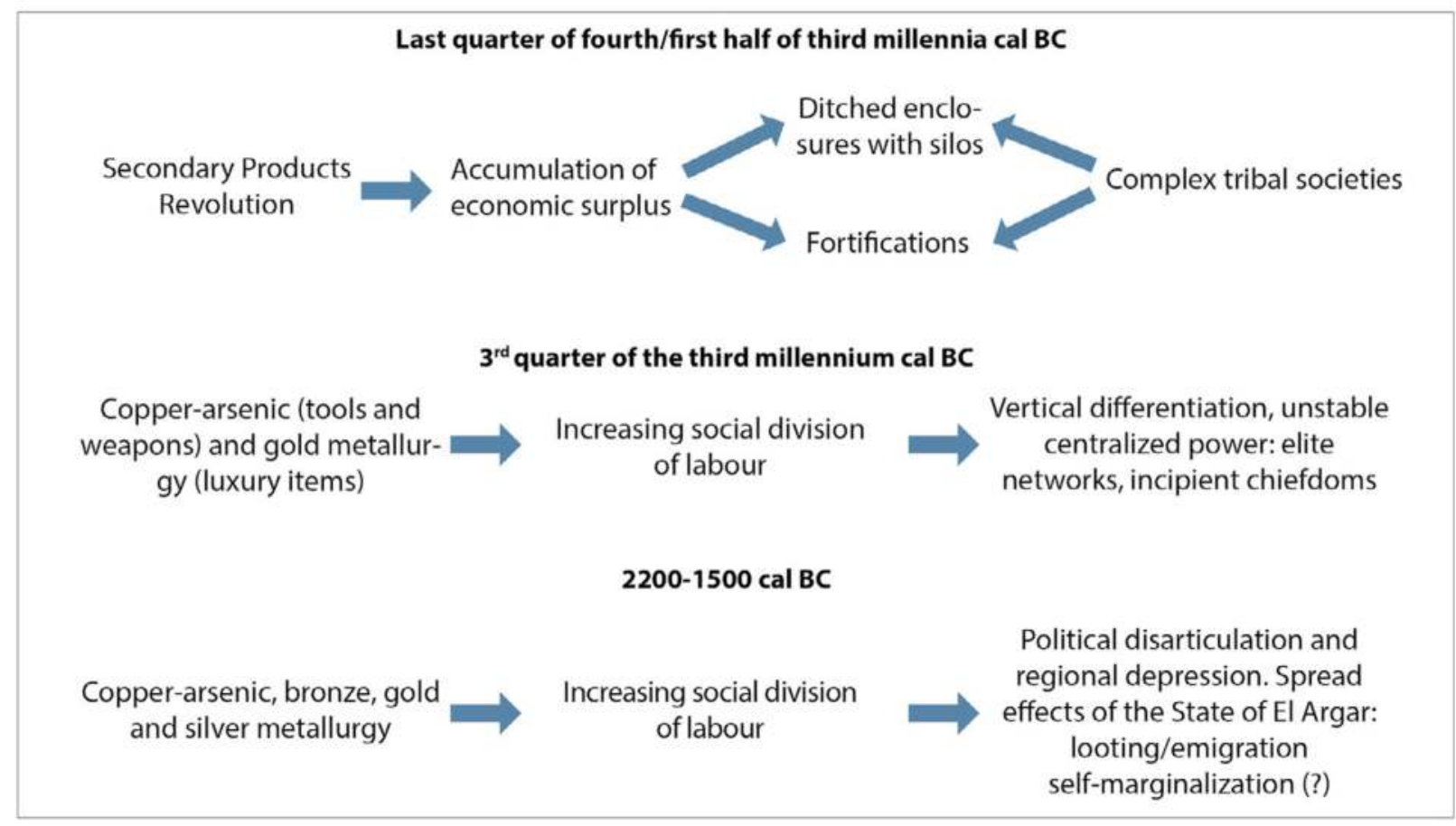

Figure 1. A general framework of social complexity in the Late Prehistory of Southern Portugal (after Soares 2016).

interpretations as, e.g., '[...] by $\sim 2000$ BCE the replacement of $40 \%$ of Iberia's ancestry, and nearly $100 \%$ of its Y-chromosomes, by people with Steppe ancestry' (Olalde et al. 2019: 1230). Worldwide generalisations are not acceptable in the presence of limited datasets, non-systematic sampling procedures, biased by local and regional research asymmetries (Furholt 2019), taphonomic loss (e.g. soil acidity has strongly hampered the preservation of organic materials, namely human bones, in our region), and insufficient diachronic control. In any case, these new inquiring methods of materialities are influencing the theoretical archaeology (Kristiansen et al. 2017; Heyd 2017). As for El Argar, the proposal of a relationship between it and south-eastern Europe, based on metalworking tools (Lull et al. 2015: 385) is hardly supported by mtDNA analysis and the haplogroup level c. 2200 BC (SzécsényiNagy et al. 2017).

Even in terms of our ready confidence in radiocarbon dating procedures, there are many problems with the selection quality of samples, the control of stratigraphy, and the contextual provenance. Most of the radiocarbon determinations attributed to the 
Portuguese Bell Beaker period (the starting point of the changeover Chalcolithic/Bronze Age) from Estremadura had been collected in highly commingled domestic layers and funerary contexts, creating the paradigm of the 'International' or 'Maritime' Bell Beaker pottery having originated in Portugal, at $c$. 2800-2750 cal BC (Salanova 2004), although confident Bell Beaker contexts have not been dated in Portugal before 2600-2500 cal BC (Table 1) (Soares and Tavares da Silva 2010). Modelling the 4th-3rd millennia evolution in southern Portugal through radiocarbon dates, bell beaker pottery starts from the middle of the 3rd millennium (Mataloto and Boaventura 2009: 65). The same is observed in other regions of Iberia (Ríos, Blasco and Aliaga 2011-2012), for example the Madrid region, with a large set of new radiocarbon dates, mainly from Camino de las Yeseras and Humanejos (Ríos 2013): the first bell beakers (International/Maritime style) appeared around the middle of the $3 \mathrm{rd}$ millennium BC, and the latest, Ciempozuelos and evolved Palmela bell beakers, disappeared in the first centuries of the 2nd millennium cal BC. We have proposed elsewhere, based only on stratigraphical and typological data (Soares and Tavares da Silva 1974-1977), a similar stylistic sequence for the Portuguese Estremadura Bell Beaker complex. Genetic information also does not confirm the Tagus Bell Beaker origin:

'We observe limited genetic affinity between Iberian and central European Beaker Complex-associated individuals, and thus exclude migration as a significant mechanism of spread between these two regions' (Olalde et al. 2018). Following this study, the results showed that the Beaker complex could not be attributed to a homogeneous group. 'Even at a local scale, the Beaker Complex was associated with people of diverse ancestries'. The 100 beaker-associated individual analyses displayed different genetic signatures from distinctive origins. The assemblages of prestigious goods from Beaker complexes, exhibited in particular situations by elites, would be intermediated by exchange networks, in some cases long-distance trade. Population mobility and cultural transactions interplayed depending on regional trajectories. In Iberia, the majority of Beaker complex-associated individuals had almost no Steppe affinities, they were genetically similar to the previous Chalcolithic Iberian populations and they had not transmitted substantial genetic contributions to central Europe. On the contrary, in Britain, the Beaker complex originated a sharp demographic transformation, as indicated by the presence of large amounts of Steppe-related ancestry after $2400 \mathrm{cal} \mathrm{BC}$. This cultural change, perhaps via small-scale movements crossing the European mainland (northern Italy, southern France), is very well represented by the Amesbury Archer, the 'Copper Age Ulysses' (Fitzpatrick 2009), who lived in the span between 2470-2280 cal BC (OxA-13541, 3895 \pm 32 BP).
In fact, the cultural change we observe in the archaeological record of the second half of the 3rd millennium cal $\mathrm{BC}$ in Iberia can be explained mostly by the socio-economic dynamics of the Late Chalcolithic societies integrated within the European economic system of prestige goods (Soares 2017) (Figure 8), instead of having resulted from massive migrations.

Beyond the empirical analysis, a broad-scale frame of reference is indispensable to interpret the prehistoric record, trying to approach societies in their cultural totality. We are not afraid to use anthropological concepts such as 'tribe', 'chiefdom' or 'state' (Kristiansen 1991; Earle 1991; 1999; Service 1962), 'egalitarian', 'rank', and 'stratified societies' (Fried 1967) as means of analysis, and not as universal socio-political organisational stages (Soares and Tavares da Silva 1998) (Figure 1). Even if these 'unfashionable' categories are subject to controversy (Scarre 2013), they are quite useful to search for pre-state socio-economic systems (Bate 2003; Carneiro 1981) and power structures (Hayden 1995) in the diverse mosaic of Iberian societies at the transition to the 2nd millennium BC (Figure 7). Historical societies can also provide useful information for comparison in order to model Prehistoric societies (Ling, Earle and Kristiansen 2018). Furthermore we are aware of the inexorable loss of information about multiple transition forms between heterarchically organised societies and state societies (Brumfiel 1995).

Highlighting the socio-economic perspective (Soares 2013a:55-77), we focus on the development of productive forces, productivity, production intensification, surplus accumulation and social division of labour (Figure 1), which are all pre-conditions for the emergence of unstable elites in Iberian late prehistory. 'Meritocracy' forms essayed during the second half of the 3rd millennium BC (Figure 7) could be an ultimate strategy to prevent state deployment, which constitutes perhaps the most unequal socio-political organisation (Clastres 1974; Gailey and Patterson 1988).

Returning to the empirical field, for different approaches and pathways, the analysis of the huge information currently available (Balsera et al. 2015) indicates for the late prehistory of the southwest a marked peak of development during the Chalcolithic (2900-2500 cal BC), and a subsequent and prolonged decline beginning with the Beaker phase c. $2500 \mathrm{cal} \mathrm{BC}$, until the onset of the Middle Bronze Age, c. 1600/1500 cal BC.

The 3rd millennium after the stratigraphy and radiocarbon chronology of Porto das Carretas: Chalcolithic society 2900-2500 cal BC

Trying to explain the deep cultural changes between the social practices of the kinship (corporate) social 


\begin{tabular}{|c|c|c|c|c|c|c|c|}
\hline Archaeological site & № Lab. & Date BP & Date cal BC $(2 \sigma)$ & Context & Associated materials & Sample & Reference \\
\hline \multicolumn{8}{|c|}{ 2nd half of the 3rd millennium cal BC. EBA } \\
\hline \multirow{3}{*}{ Moita da Ladra } & Sac-2371 & $3810 \pm 60$ & $2470-2050$ & Vala 3 & \multirow{3}{*}{$\begin{array}{l}\text { International Bell Beaker } \\
\text { pottery style }\end{array}$} & \multirow{3}{*}{ Animal bones } & \multirow{3}{*}{$\begin{array}{l}\text { Cardoso, Soares and } \\
\text { Martins, 2013. }\end{array}$} \\
\hline & Sac-2122 & $3700 \pm 50$ & $2280-1940$ & ML55 (30-45) & & & \\
\hline & Sac- 2123 & $3700 \pm 50$ & $2280-1940$ & ML9 (30-45) & & & \\
\hline \multirow[b]{2}{*}{ S. Pedro do Estoril 1} & Beta-178467 & $3830 \pm 40$ & $2460-2140$ & Human femur, inv. 1892 & \multirow{2}{*}{$\begin{array}{l}\text { Palmela Bell Beaker } \\
\text { pottery style }\end{array}$} & Human femur & \multirow[b]{2}{*}{ Gonçalves, 2005.} \\
\hline & Beta-178468 & $3790 \pm 40$ & $2401-2045$ & $\begin{array}{l}\text { Human phalanx with gold } \\
\text { spiral ring. }\end{array}$ & & Human phalanx & \\
\hline $\begin{array}{c}\text { Hipogeu } 1 \\
\text { Quinta do Anjo }\end{array}$ & Beta-496305 & $3720 \pm 30$ & $2201-2032$ & & $\begin{array}{l}\text { Palmela Bell Beaker } \\
\text { pottery style }\end{array}$ & Human jaw & $\begin{array}{l}\text { Gonçalves, Sousa and } \\
\text { Santos, } 2018 .\end{array}$ \\
\hline \multirow{2}{*}{ Malhadas } & Beta-126091 & $4140 \pm 70$ & 2336-1912 & Archaelogical layer (C.2b) & \multirow{2}{*}{$\begin{array}{l}\text { Palmela Bell Beaker } \\
\text { pottery style }\end{array}$} & \multirow{2}{*}{ Ruditapes decussatus } & \multirow{2}{*}{ Soares, 2003.} \\
\hline & Beta-126090 & $3980 \pm 70$ & $2117-1711$ & Archaelogical layer (C.2a) & & & \\
\hline Chibanes & Beta-164906 & $4200 \pm 80$ & $2444-1980$ & $\begin{array}{l}\text { Locus L12/P10. C.6B/4B } \\
\text { (Phase ID) }\end{array}$ & $\begin{array}{l}\text { Palmela Bell Beaker } \\
\text { pottery style }\end{array}$ & Ruditapes decussatus & $\begin{array}{l}\text { Tavares da Silva and } \\
\text { Soares, } 2014 .\end{array}$ \\
\hline \multirow{2}{*}{ Freiria } & & & & \multirow{2}{*}{ Bell Beaker hut foundation } & \multirow{2}{*}{$\begin{array}{l}\text { Palmela Bell Beaker } \\
\text { pottery style }\end{array}$} & \multirow{2}{*}{ Animal bones } & \multirow{2}{*}{$\begin{array}{l}\text { Cardoso, Cardoso and } \\
\text { Encarnação, } 2013 .\end{array}$} \\
\hline & Beta-296577 & $3630 \pm 40$ & $2130-1890$ & & & & \\
\hline \multirow{3}{*}{$\begin{array}{l}\text { Barranco do } \\
\text { Farinheiro }\end{array}$} & Beta - 386974 & $4010 \pm 30$ & $2616-2469$ & EU 4, A.5-17 & \multirow{3}{*}{ Decorated Bell Beakers } & & \\
\hline & Beta - 331680 & $3930 \pm 30$ & $2550-2300$ & EU 3 & & Charcoal & $\begin{array}{l}\text { Gonçalves, Sousa and } \\
\text { Andrade, } 2017 .\end{array}$ \\
\hline & Beta -425876 & $3900 \pm 30$ & $2469-2298$ & EU 4, A.5-28 & & & \\
\hline Miguens 3 & Wk-18507 & $3934 \pm 33$ & $2570-2300$ & EU 35 & International Bell Beaker & Charroale Olea & Mataloto and \\
\hline 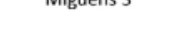 & Wk-18508 & $3902 \pm 38$ & $2480-2230$ & EU 55 & pottery style & Charcoal: Olea & Boaventura, 2009. \\
\hline & Beta-196681 & $3920 \pm 40$ & $2490-2290$ & C.2B2, Tower M13 - hearth D & & Charcoal: Pinus pinea & \\
\hline (Phase II) & Beta-204062 & $3860 \pm 40$ & $2460-2200$ & C. 2 B2, Tower M13 - hearth B & $\begin{array}{l}\text { International Bell Beaker } \\
\text { pottery style }\end{array}$ & Charcoal: Pinus pinea & Soares, 2013a. \\
\hline & Beta-193743 & $3840 \pm 60$ & $2470-2130$ & C. $2 \mathrm{~B} 2$, Tower $\mathrm{M} 13$ - hearth $\mathrm{A}$ & & Charcoal: Olea & \\
\hline & ICA-16B/0914 & $4030 \pm 30$ & $2630-2470$ & Hut 1, EU 267 & & Cervus elaphus & \\
\hline & ICA-16b/0912 & $4010 \pm 30$ & $2620-2470$ & Hut 1, EU 393 & & Sus sp. & \\
\hline & ICA-17B/1149 & $4000 \pm 30$ & $2580-2470$ & Hut 2, EU 421 & & Big mammals & \\
\hline Perdigões & Beta-315719 & $3780 \pm 30$ & $2290-2140$ & Ditch 1, EU 118 & Decorated Bell Beakers & Sus tooth & $\begin{array}{l}\text { Valera and Basilio, } \\
2017 .\end{array}$ \\
\hline & Beta-315716 & $3770 \pm 30$ & $2290-2060$ & Ditch 1, EU 11 & & Sus humerus & \\
\hline & ICA-17B/0104 & $3700 \pm 30$ & $2200-1980$ & Pit 79/Cairn 488 & & Animal bone & \\
\hline & ICA-16B/0913 & $3690 \pm 30$ & $2200-1980$ & Pit 79/Cairn UE 500 & & Cervus elaphus & \\
\hline Porto Torrăo & Sac-2027 & $3810 \pm 50$ & $2460-2060$ & Ditch 2, EU 2056 & Decorated Bell Beakers & Animal bones & Valera 2013 \\
\hline & Sac-2028 & $3700 \pm 60$ & $2290-1920$ & Ditch 2, EU 2020 & Decorated Bell Beakers & Animal bones & Valera, 2013. \\
\hline Quinta do Castelo 1 & ICA-16B/0304 & $3890 \pm 30$ & $2470-2290$ & Burial & Decorated Bell Beakers & Human bone & $\begin{array}{c}\text { Valera, Mataloto and } \\
\text { Basilio, } 2019 .\end{array}$ \\
\hline Monte da Velha 1 & Beta-194027 & $3900 \pm 40$ & $2490-2210$ & Secondary burial & $\begin{array}{l}\text { Ferradeira material } \\
\text { culture }\end{array}$ & Human bone & Soares, 2008. \\
\hline & Sac-2791 & $3940 \pm 50$ & $2497-2204$ & EU 12, Oss. 1 & & & \\
\hline Tholos Centira ? & Sac- 2790 & $3900 \pm 45$ & $2469-2205$ & EU 13, Burial 2 & Ferradeira material & Human bones & Henriaueset ol 2013 \\
\hline Tholos Centira 2 & Sac-2782 & $3760 \pm 70$ & $2404-2058$ & EU 14, Burial 4 & culture & Human bones & \\
\hline & Sac-2788 & $3810 \pm 80$ & 2179-1957 & EU 7, Burial 1 & & & \\
\hline Bela Vista 5 & Beta-330091 & $3740 \pm 30$ & $2270-2040$ & Funerary pit & $\begin{array}{c}\text { Ferradeira material } \\
\text { culture }\end{array}$ & Human bone & Valera, 2014. \\
\hline & & & First half of the 2 nd & millenium cal BC "Southwest B & ironze Age Culture I" & & \\
\hline & Sac- 2878 & $3390 \pm 40$ & $1870-1560$ & Hypogeum MT6.59 & & & \\
\hline & Sac - 2867 & $3380 \pm 40$ & $1770-1530$ & Hypogeum MT6.59 & & & \\
\hline Montinho 6 & Sac - 2877 & $3360 \pm 45$ & $1750-1530$ & Hypogeum MT6.153 & Southwest Bronze Age I & Human bones & Valério et al. , 2015. \\
\hline & Sac -2879 & $3360 \pm 40$ & $1740-1530$ & Hypogeum MT6.159 & & & \\
\hline & Sac - 2876 & $3350 \pm 80$ & $1880-1450$ & Hypogeum MT6.20 & & & \\
\hline Horta do Folgăo & Sac - 2557 & $3400 \pm 50$ & $1877-1535$ & Hypogeum 3 & Southwest Bronze Age I & Human bone & $\begin{array}{c}\text { Nunes da Ponte et al. , } \\
2012 .\end{array}$ \\
\hline Torre Velha 3 & Sac - 2825 & $3280 \pm 50$ & $1680-1450$ & Hypogeum [1267][1792] & Southwest Bronze Age I & Human bone & Valério et al ., 2014. \\
\hline Herdade do Pomar & ICEN - 87 & $3510 \pm 45$ & $1951-1695$ & Cist 1 & Southwest Bronze Age I & Human bone & Gomes, 1994. \\
\hline Abelheira 1 & Sac - 2918 & $3460 \pm 40$ & $1900-1670$ & Cist AB1.13 & Southwest Bronze Age I & Human bone & Valério et al. , 2015. \\
\hline Monte da Cabida 3 & Sac -2888 & $3490 \pm 50$ & $1940-1690$ & Pit 41/931 & Southwest Bronze Age I & Human bones & Valério et al. 2014 \\
\hline & Sac- -2437 & $3330 \pm 45$ & $1690-1510$ & Pit 64 & & & \\
\hline Torre Velha 12 & Sac -2833 & $3450 \pm 45$ & $1890-1640$ & Pit TV12.13.3 & Southwest Bronze Age I & Human bone & Valério et al. , 2015. \\
\hline Vale Frio 2 & Sac - 2917 & $3360 \pm 70$ & $1880-1500$ & Pit VF2.38 & Southwest Bronze Age I & Human bone & Valério et al. , 2015. \\
\hline Torre Velha 3 & Sac - 2882 & $3330 \pm 50$ & $1740-1500$ & Pit 969 & Southwest Bronze Agel & Human bones & Valério et al. , 2014. \\
\hline & Sac -2883 & $3290 \pm 50$ & $1690-1450$ & Pit 1991 & & & \\
\hline
\end{tabular}

Table 1. Selection of radiocarbon dates of the second half of the 3rd, first half of the 2 nd millennia cal BC in central-southern Portugal. 


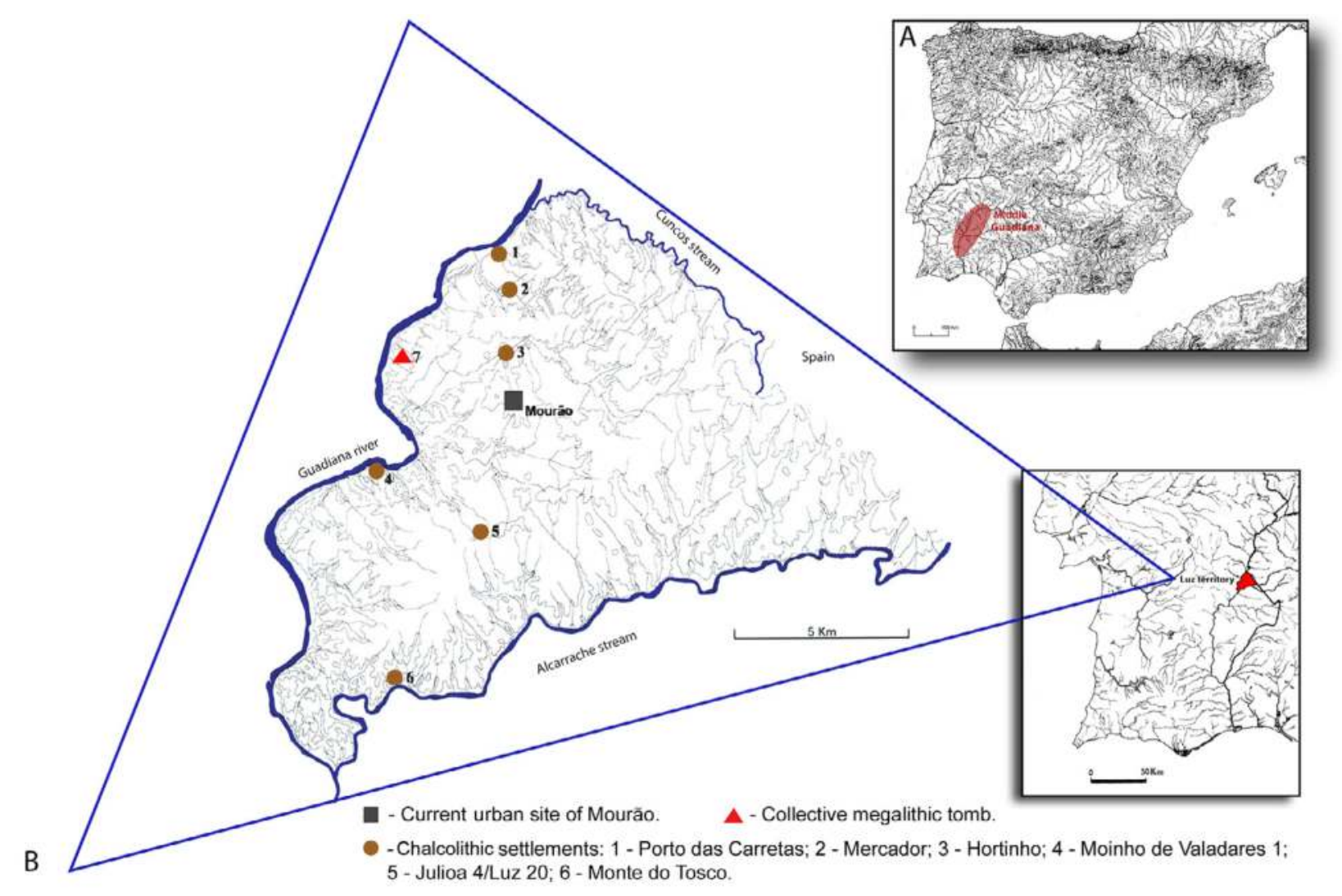

Figure 2. A) The Middle Guadiana River Basin in the Iberian Peninsula; B) Geographical setting of the Chalcolithic fortification of Porto das Carretas integrated in the local productive system of the Luz territory. First half of the 3rd millennium cal BC (after Soares 2016).

system inherited from Late Neolithic or 'Megalithic' societies and the chiefdom-oriented power of Bell Beaker elite networks (Figure 7), our initial example is the fortified site of Porto das Carretas, c. 1 ha, on a spur over the Guadiana river (Figure 2) and founded around $2900 \mathrm{cal} \mathrm{BC}$ (Phase I). It was destroyed by a huge fire c. $2580 / 2500 \mathrm{cal} \mathrm{BC}$ - which made a clear cut between the long-lasting traditional kinship based society, and a new power structure of an unstable chiefdom-oriented society of the second half of the $3 \mathrm{rd}$ millennium (Figure $3 \mathrm{~A})$. Probably in the course of two generations, roughly 70 years, the site was abandoned (Soares 2013a; 2016).

The military architecture (walled enclosure, with tower and semi-circular bastions) of Phase I (Figure $4 \mathrm{~A}-\mathrm{C}$ ) and its material culture, besides the local profile and the particularity of the site, integrate the general pattern of the southern Iberian Chalcolithic Identity coast to coast (Hurtado 2010). This type of settlement is not sustainable on its own, although most have been studied singly; the same can be applied currently to the ditched enclosures.

To improve the territorial perspective, our enquiries extended to the regional scale, revealing a new model for the settlement system of the southwest Chalcolithic based on a concept of the local productive system (Soares 2016: 82), which corresponds to a minimal area of an organised community with shared geography, balanced income redistribution, common ancestors, and similar believes and survival aims. In such a territorial unity, all sites were interconnected (Figure 4D, Luz territory); the resources were exploited in a very skilled way, oriented to successful outcomes for the whole local productive system. Each part of the system was represented by functionally distinct sites, accordingly with its articulation linked to a collective project of efficient exploitation of the territory: open sites in particularly rich ecotones, e.g. the pit-site of Mercador, fortified sites on the territory's borders, such as Porto das Carretas and Monte do Tosco, and a ditched enclosure located as usual on the most fertile areas of the territory (Julioa 4/Luz 20). The local productive system of the Luz territory could correspond to a segment of a tribal society (Fig 4D) whose main centre could be located at La Pijotilla (Badajoz) (Figure 4D). With c. 80 ha, this is the largest mega-site known in the Middle Guadiana Basin, deployed on the most productive soils of the region, generated by the alteration of Miocene deposits (Hurtado 2010). Large, ditched enclosures would include the functions of residence, labour aggregation, storage of foodstuffs and water, celebration and 


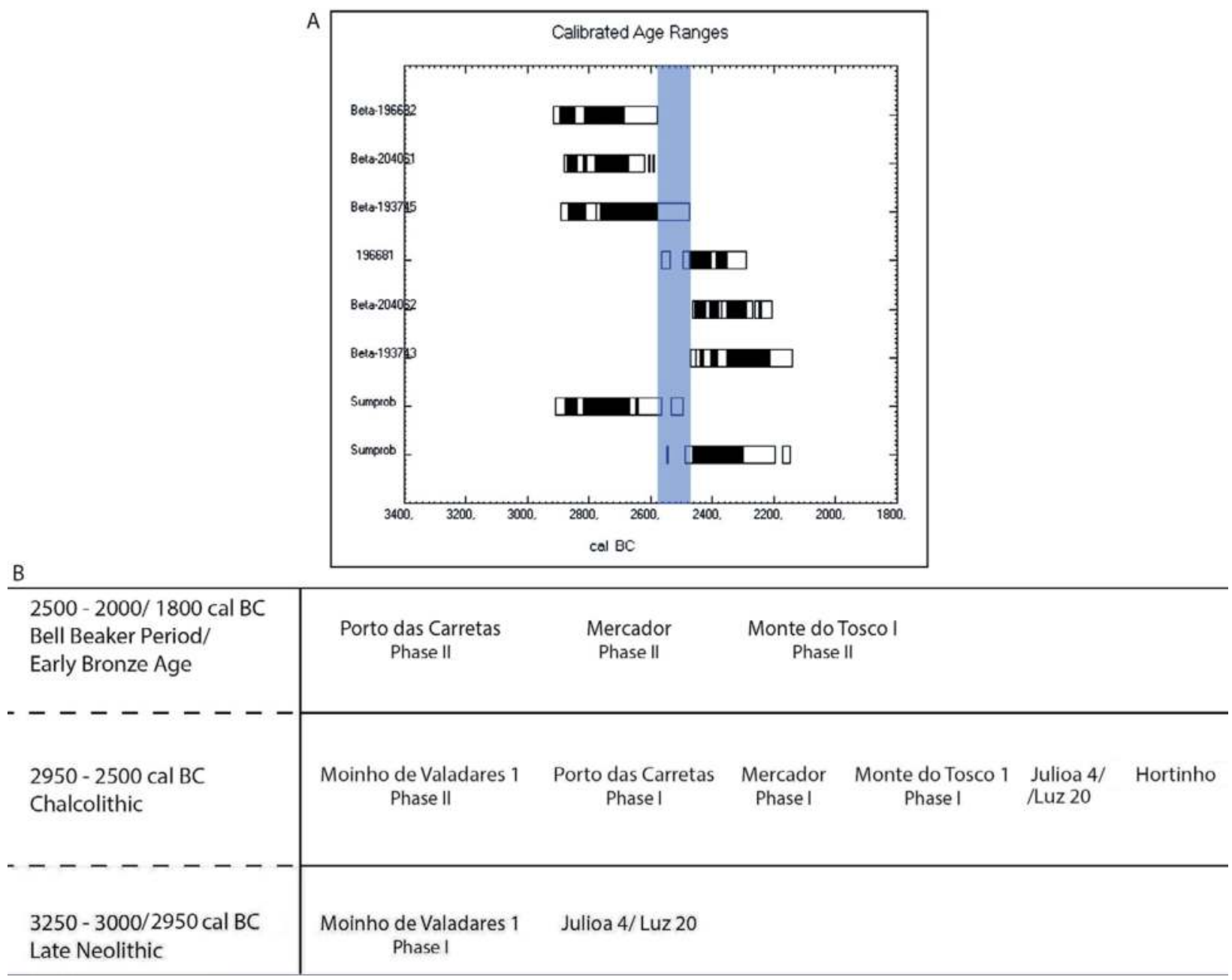

B

Figure 3. A) The stratigraphy and radiocarbon chronology of Porto das Carretas showed two phases of occupation, separated by an abandonment caused by extensive fire. Phase I corresponds to the first half of the 3rd millennium cal BC, and phase II occurred in the third quarter of the same millennium; B) The main sites of the Luz territory settlement system. It emerged in the Late Neolithic, reached its peak of demographic increase in the first half of the 3rd millennium and declined in the second half of the same millennium (after Soares 2016).

religious meetings, and funerary practices. Indeed, it is very difficult to find in the archaeological record a separation between profane and sacred spaces/ behaviours, as their boundaries may have not existed within prehistoric societies (Márquez 2003). Those central places would have some attributions in rear defence, but the functions of surveillance and defensive vanguard of the territory were guaranteed by small- or medium-sized border fortifications, such as Porto das Carretas, Monte do Tosco, Cerro dos Castelos de S. Brás (Parreira 1983), on the left bank of the Guadiana, or Monte da Tumba in the Sado Basin (Tavares da Silva and Soares 1987). Each local productive system would be integrated within the whole tribal territory, polarised by a mega-site of complex, ditched enclosures, e.g. La Pijotilla (Figure 4D) in the Middle Guadiana Basin, or Porto Torrão (c. 100 h) in the Sado Basin, Valencina de la Concepción in the Guadalquivir Basin (c. 450 h), or Alcalar (c. $30 \mathrm{~h})$ on the Algarve coast. The economies of the Chalcolithic societies of southwest Iberia were based on an integrated and intensive agroforestry/ livestock strategy, complemented by hunting, fishing and gathering, oriented to the production of economic surplus (Soares 2013a: 350-60). The bone pathology in the metatarsal observed from the faunal remains of Bos taurus, from the site of Mercador (Valera 2013a), an open-site satellite of Porto das Carretas, was attributed to the plough and cart traction. Bovine traction applied to agriculture substantially increased the area a person can work with hoe and allowed the cultivation of the thickest and most fertile soils, thereby increasing profit and lessening the fallow cycle.

The regional variant of the Mediterranean polyculture agro-managerial model (Gilman 1981) generated in Alentejo and Andalucia a particular anthropogenic landscape (Soares 1994; 2013a; Stevenson and Harrison 1992), referred to as montado/dehesa. This was the result 

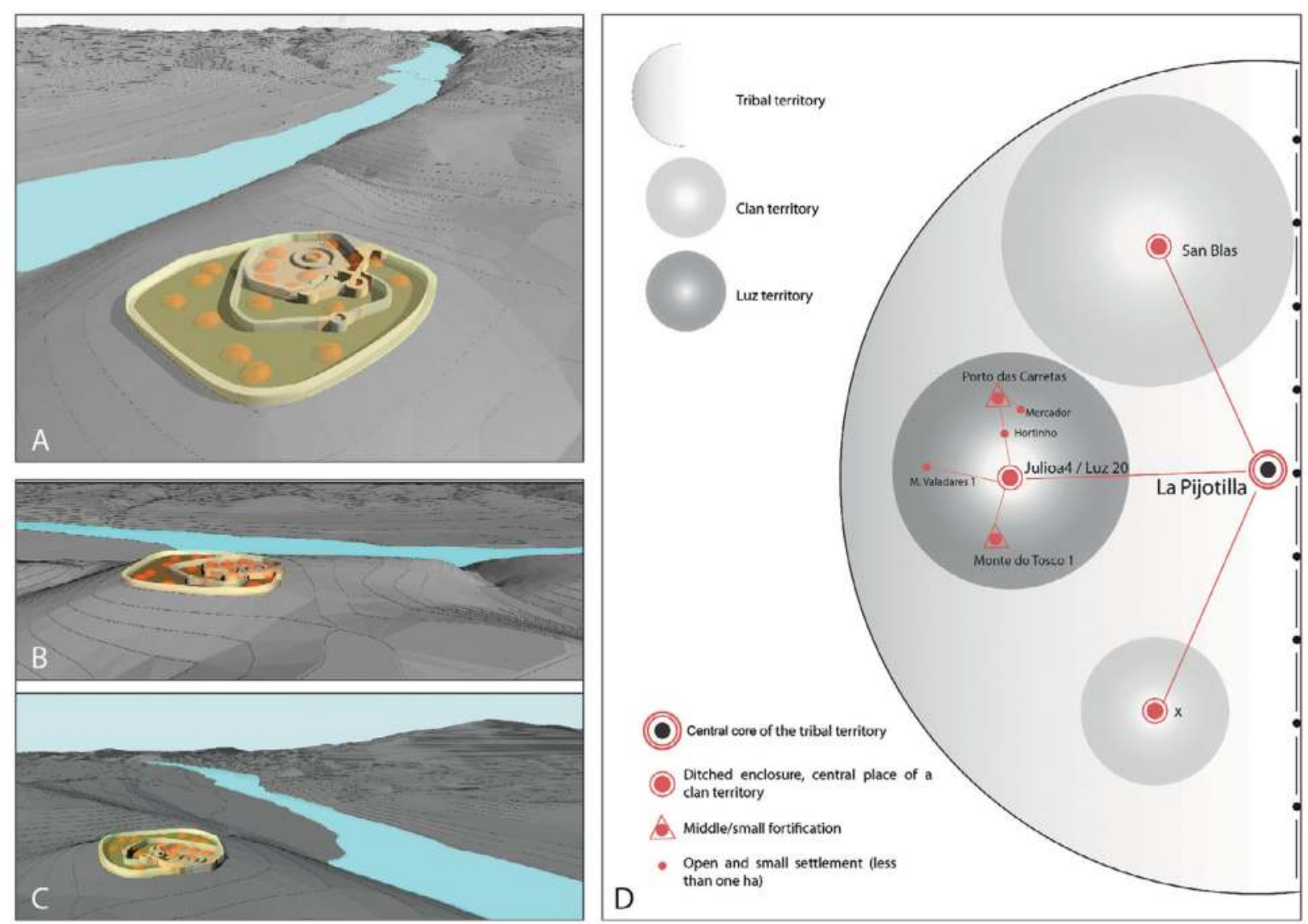

Figure 4. Architectural reconstruction of Porto das Carretas, Phase I, by António Alfarroba (in Soares 2013a). The two main locative factors were the good position for the surveillance of the Guadiana river and the proximity of fertile soils: A) From southwest to upstream; B) Southeast view; C) View from east to downstream; D) A complex tribal organisation model for the Middle Guadiana Basin in the first half of the 3rd millennium cal BC commanded by La Pijotilla. The Luz territory could correspond to a clan segment (after Soares 2016).

of high-return pig grazing in evergreen oak forests, dominated by Quercus rotundifolia and Quercus suber, taking advantage of the huge production of holm oak acorns. Pigs were a very important food resource, in association with sheep, goats and bovids; the presence of ivory figurines of pigs and acorns in the tholos of Montelirio (García Sanjuan et al. 2018a) is in accordance with the economic value of the montado ecosystem. In general, the preservation of organic remains in the southwest of the Iberian Peninsula is very poor due to the acidic nature of soils, but in some particular situations, like the Chalcolithic macro-village of Alcalar (Morán 2014), located on limestone, a large set of macro-botanic remains were preserved, displaying a diverse ensemble of cultivated species, with the major crops including cereals (Triticum aestivum, Hordeum vulgare), legumes (Vicia faba, Pisum fabacea), and also linen (Linum usitatissimum), Papaver somniferum, and vines (Vitis vinifera L.). Fruit trees, such as olive (Olea europaea) and pear/apple (?) (Pyrus sp.) were the least favoured, as observed at Porto das Carretas (Tereso et al. 2011).
In short, we propose a complex tribal organisation for the first half of the third millennium cal BC in southern Portugal by crossing archaeological data with the anthropological concepts of unilocal/plurilocal clan and conical territory (Friedman and Rowlands 1982). This social model, rooted in the kinship structure, inherited from the Late Neolithic, allowed a growing social inequality promoted by competing lineages with unequal status legitimated by the genealogical distance to the mythic ancestor (Sahlins 1963). Communitarian ideology would hide the uneven wealth distribution inside the limits of psychosocial pressure. The intertribal sphere could have been the escape valve of conflict.

There is evidence for the emergence of economic specialisation in textile production. Although it would have been embedded in the domestic activities, weaving was spatially segregated at Porto das Carretas (Soares 2013a: 389-393). This observation can support the idea of an emerging trend to full-time craftspeople, completely exempted from agriculture and animal 


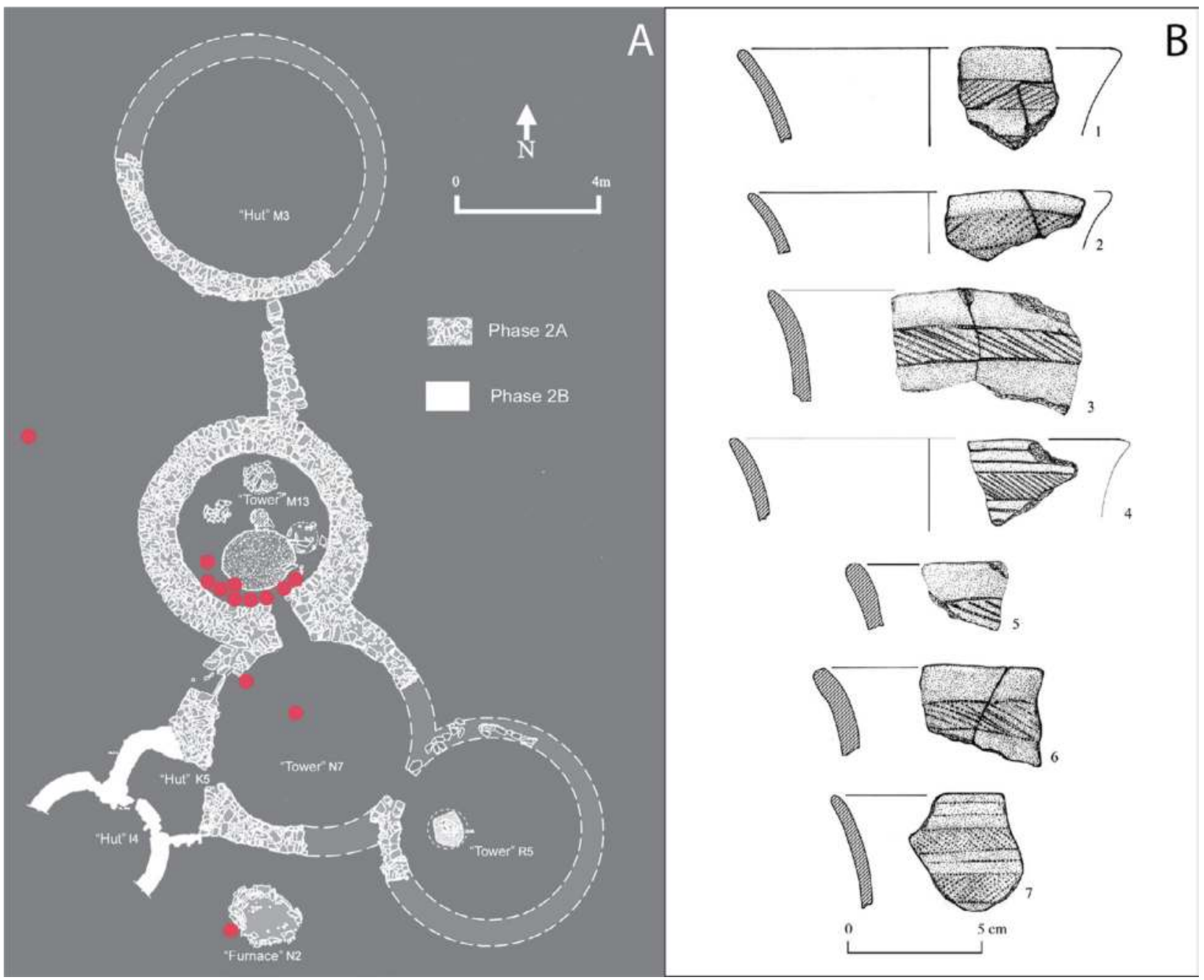

Figure 5. A) Porto das Carretas, Phase II. Distribution of Bell Beaker pottery (International style) $(\bullet)$ on the architectural plan of Porto das Carretas, constituted by a set of three terraced and monumentalised towers interconnected, three huts and a metallurgical furnace, built in the open space; B) Porto das Carretas, Phase II. Bell Beaker pottery (International style) (after Soares 2016).

husbandry (social division of labour). From Andalucía (the Montelirio tholos), expressive data has arrived to support the proposal of social division of labour in southern Iberia in the first half of the 3rd millennium: the luxury beaded textiles (about a million perforated beads in shell, limestone, greenstones, ivory and amber) used to dress corpses of a probable female priestess community inhumated in the large chamber of the Montelirio tholos. For manufacturing those ceremonial costumes, it would have been necessary to spend c. 200,000 hours of work. This corresponds to 208 persons working full-time over some six months (DíazGuardamino, Wheatley, Williams, Garrido 2016).

In general, we can hypothetically admit that Chalcolithic societies could achieve the coordination required for political action, as well as the previous Megalithic organisation, through assemblies, consensus, local solidarity, communal rituals and collective graves. The political power could be shared among multiple loci, preventing state formation (Clastres 1974; 1987). Ancestors would still be playing a relevant role in structuring the social relations of the living, even if investment in funerary architectures dropped, regardless of the Neolithic megalithic tombs. In the Chalcolithic, the investment in architectural projects was shared between funerary and domestic spaces. The latter became progressively more exigent due to increasing sedentism and growing interlineage, as well as inter-tribal competition and conflict at the transition to the 3rd millennium onwards. Thus, the major innovation of this time in funerary architecture was the introduction of a new type of collective tomb - the tholos: much easier to build and with less consummation of raw material and workforce requirements. The construction of this new type of collective funerary monument spread over southern Iberia from the end of the 4 th and during the first half 


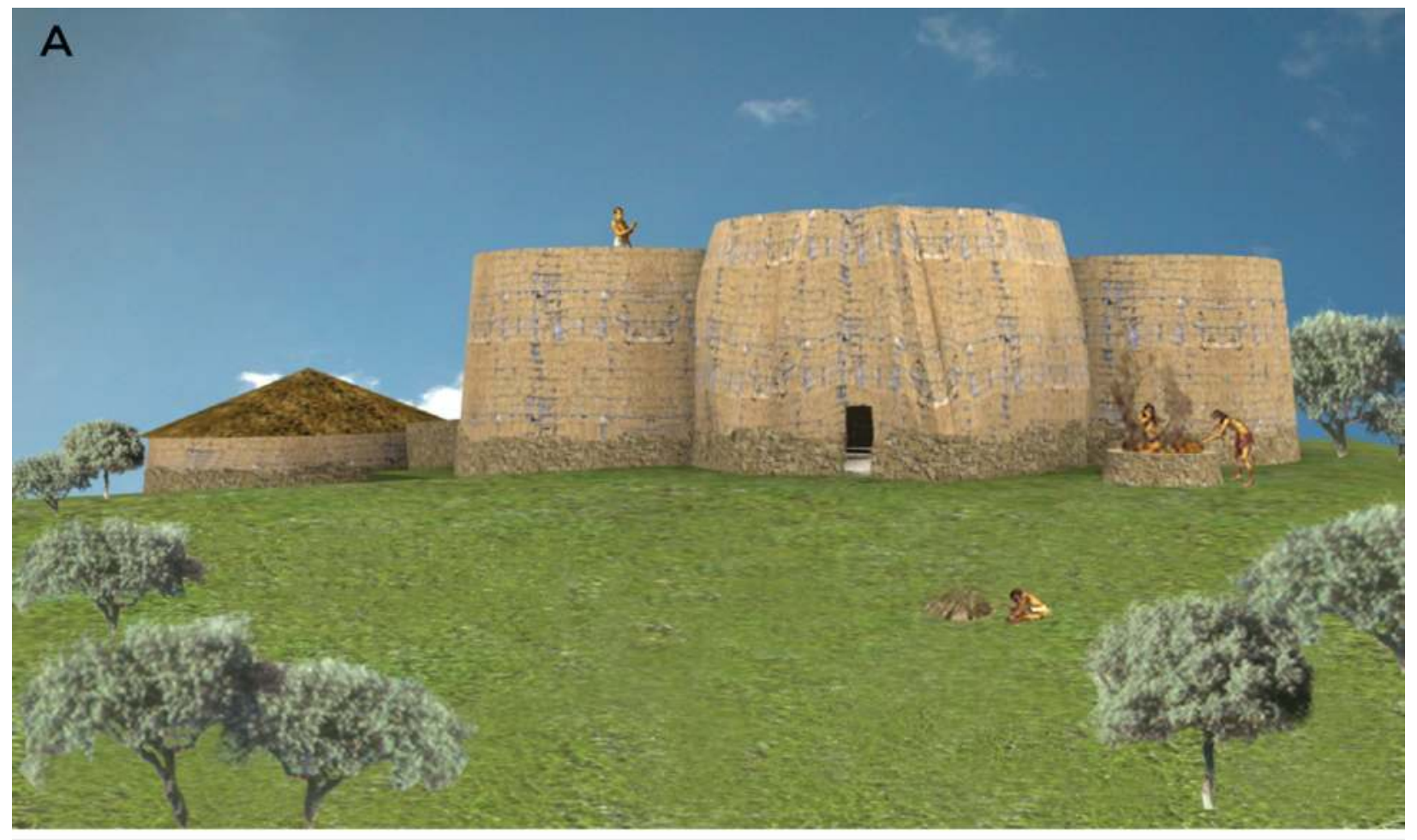

B

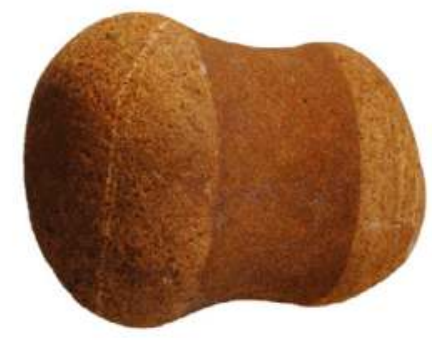

0 $4 \mathrm{~cm}$ 1
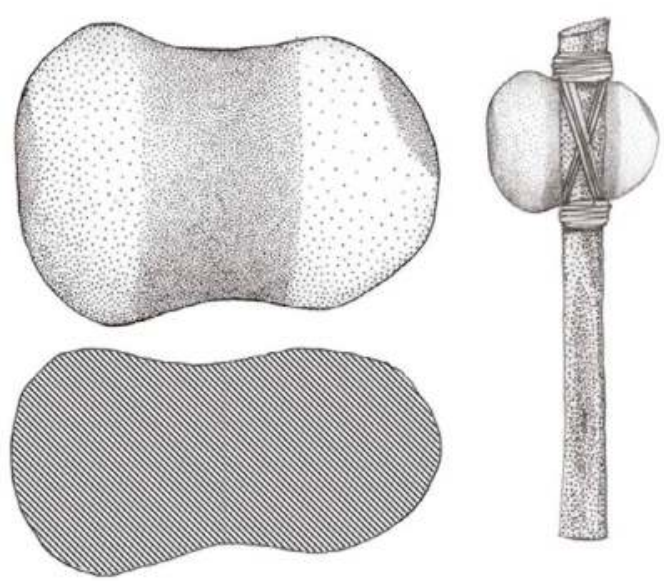
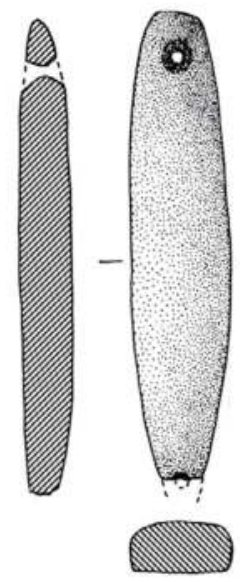

Figure 6. A) Architectural reconstitution of Porto das Carretas in Phase II. Southwest view (drawing by C. Menezes, in Soares 2013a); B) Porto das Carretas, Phase II (Bell Beaker complex): a probable forging hammer on a quartzite pebble and a polished wrist-guard on quartzite (after Soares 2013a).

of the 3rd millennium. At Valencina, tholoi construction started at about 3200, peaked at 2900/2800 and lasted until 2400 cal BC (García Sanjuan et al. 2018b). In southcentral Portugal, tholoi also emerged at the end of the 4 th, but appearing mostly from the early $3 \mathrm{rd}$ millennium (Sousa 2016). However their use could extend during the second half of the 3rd millennium, receiving single burials of the Horizon of Ferradeira, as observed at the tholoi of Monte da Velha 1 (Soares 2008) and Cardim 6, or Bell-Beaker inhumations, e.g. the tholos of Praia das Maçãs. The calibrated radiocarbon dates at $2 \sigma$ of those final moments of tholoi (re)utilisation are respectively:
Beta-104027, 3900 \pm 40 BP = 2479-2211 (Soares, 2008); SANU-53037, 3795 \pm 26 BP $=2297-2140$ (Valera et al. 2019); $\mathrm{H}-2048 / 1458,3640 \pm 60 \mathrm{BP}=2295-1865$ (Soares and Cabral 1984).

Underlying the general trends of the political organisation of the Chalcolithic of southern Iberia, quite different trajectories of change could occur at regional and local scales between segments encompassing the same tribal unity, or regarding different tribes. Power exercise and social inequality could have distinct configurations. At Estremadura, for example, intra- 
social inequality and communitarian principles seem to have been under control (Soares 2003; Tavares da Silva and Soares 2014) when compared with Guadalquivir valley, where the funerary record of Valencina (Seville) displayed a sharp intra-site social inequality (García Sanjuan et al. 2018b); in fact, a strong hierarchical social organisation, probably dominated by a theocratic power, could have succeeded to a 'paternalist' kinship society.

Increasing contradictions related to the rise of intrasocial inequality inside a complex ideological system pretending to submit to communitarian principles, without an institutionalised coercive force, would create internal stress that could hardly be absorbed by the inter-tribal conflict zones. From an economic perspective, this type of political power, based on kinship and sacred ancestors, with a tangle of restrictive norms, would block the productive forces of the most innovative sectors (craftwork and trade of metals, salt and textiles). Thus, the whole complex tribal organisational model started to crumble at 2500/2400 cal BC onwards. At Valencina, the funerary activity declines from 2400 cal BC onwards; the site probably survived with reduced output until the Early Bronze Age; activity in copper metallurgy continued until the last quarter of the 3rd millennium BC (García Sanjuan 2013; García Sanjuan et al. 2018a, 2018b).

\section{Reading the signs of the collapse of the Chalcolithic society and the evidence of the southwest Early Bronze Age}

\section{International/maritime Bell Beaker complex in the Late Chalcolithic/dawn of the Early Bronze Age (EBA1): 2500/2400-2200 cal BC}

After the abandonment of Porto das Carretas, which may have lasted about two generations, a new architectural project was deployed on the remains of the old Chalcolithic fortification. A set of three monumentalised and terraced towers, three huts, and a metallurgical furnace were constructed (Figs. 5-6) and used between c. 2500-2200 cal BC.

The central tower, N7, has an internal diameter of $5.70 \mathrm{~m}$; its walls are $0.90 \mathrm{~m}$ and $1.5 \mathrm{~m}$ wide. The best similarities for this architecture are found in the tower of Miguens 3 (Calado 2006), constructed ex-nihilo on the opposite bank of the Guadiana, and the tower of Monte da Tumba, with a sub-circular plan and an external diameter of $12 \mathrm{~m}$, built on the remains of a Chalcolithic fortification (Tavares da Silva and Soares 1985; 1987). Both were built in the Bell Beaker period (International ceramic stylistic group and Mixed-Maritime Bell Beaker style).
The architectural features of the Bell Beaker occupation phase of Porto das Carretas, associated with prestige goods such as arsenic copper, socially-prominent lithic artefacts and international/maritime Bell Beaker pottery (Figs. 5-6), compared to perishable domestic structures, can be interpreted as a metaphor for the emerging new social organisation, based on 'omniscient' leaders (Soares 2013a: 69) and followers, integrated in multi-scale elite networks. At the same time, in the Portuguese Estremadura there are also some stone structures over the ruins of the walled enclosures of the first half of the 3rd millennium, such as towers A and B of Zambujal (Sangmeister and Schubart 1981; Kunst and Arnold 2011), or even new architectural foundations, i.e. Moita da Ladra (Vila Franca de Xira) (Cardoso, Soares and Martins 2013), a walled enclosure with a large tower of sub-circular plan and about $10 \mathrm{~m}$ in diameter, associated with Mixed-Maritime Bell Beaker pottery and prestige items, including gold ornaments. The ditched enclosure of Barranco do Farinheiro (Coruche) also seems to have a late foundation at about $2600 \mathrm{cal}$ BC. The excavations delivered Mixed-Maritime, Ciempozuelos and evolved Palmela Bell Beaker pottery (Gonçalves, Sousa and Andrade 2017).

Returning to the Middle Guadiana Basin, in the second half of the $3 \mathrm{rd}$ millennium cal $\mathrm{BC}$, we observe that the previous local productive system of the Luz Territory had collapsed. The population density had probably decayed, along with the number of sites (Figure 3B). The demographic pressure over the landscape was reduced, enhancing the development of a supra-Mediterranean forest, with the growth of Quercus faginea, as well as the development of the riparian forest (Fraxinus angustifolia) (Duque Espino 2004; Queiroz and Tereso 2013). The role of the $4.2 \mathrm{ky}$ BP event (abrupt climate change $c$. 2350/2450-1850/1950 cal BC that led to a colder and drier climate regime) could not be directly associated with the social dynamics of the Late Chalcolithic/Early Bronze Age cycle at a local or even regional scale (Risch et al. 2015; Lull et al. 2015: 391). In Phase II at Porto das Carretas, the river no longer seems to have formed a rigid boundary, as it was in Phase I, becoming instead an axis of interaction. Metallurgical remains and marine-estuarine shells, perhaps related to salt trading (Soares 2008; 2013b), suggest the integration of Porto das Carretas in regional exchange networks. A set of 14 International or Maritime Bell Beaker vessels, although locally/regionally manufactured, connected this site with a long-distance exchange network, in an economic system of prestige goods, with sub-continental expansion (Figure 8).

Dwelling-space reduction in the macro-villages seems to be a general trend in southern Iberia (Pajuelo Pando and López Aldana 2016; Tavares da Silva and Soares 1987; Morán 2014), connected with deep social changes. 


\section{Pre-state socio-economic systems of Iberian Southwest; $3^{\text {rd }}$ millennium cal BC}

(adapted from Soares 2013a)

\begin{tabular}{|c|c|c|}
\hline Socio-economic indicators & $\begin{array}{l}\text { Hierarchical complex tribal system } \\
\text { First half of the } 3^{\text {rd }} \text { millenium }\end{array}$ & $\begin{array}{c}\text { Elite networks } \\
\text { Second half of the } 3^{\text {rd }} \text { millenium }\end{array}$ \\
\hline Power strategy & $\begin{array}{l}\text { Diffused but stable, based on kinship relations } \\
\text { associated to ancestors cults; in it's extreme } \\
\text { version it can take the form of theocratic } \\
\text { power. E.g. Valencina de la Conception/Mon- } \\
\text { telírio tholos. }\end{array}$ & $\begin{array}{c}\text { Centralized/personalized and unstable power } \\
\text { based on the flow of prestige goods by large } \\
\text { exchange networks. E.g. phase II } \\
\text { of Porto das Carretas. }\end{array}$ \\
\hline Social relations of production & $\begin{array}{l}\text { Exploitation and extorsion of surplus encapsu- } \\
\text { lated in communitary principles; lineages } \\
\text { competion at high rank levels; maintenance of } \\
\text { solidarity at the lower segments of each group. }\end{array}$ & $\begin{array}{l}\text { Feudalization relationships; individual prestige } \\
\text { inside inter-group networks; meritocracy principles. } \\
\text { Wealth-based social relations. Control of craftwork } \\
\text { in mettalurgical and textile productions. Social } \\
\text { relations of prodution with expoitation legitimated } \\
\text { by chiefs "wisdom". }\end{array}$ \\
\hline Scale of action & Local/regional. & $\begin{array}{l}\text { Regional/"global" (long distance prestige } \\
\text { goods trade). }\end{array}$ \\
\hline Ideological strategies & $\begin{array}{l}\text { Communal rituals, collective representations, } \\
\text { ancestors and fertility cults; traditional and } \\
\text { religious knowledge. }\end{array}$ & $\begin{array}{l}\text { Personalised power representation; increase } \\
\text { of sociothecnic artifacts; manipulation of } \\
\text { prestige goods, rhetoric of heritage. }\end{array}$ \\
\hline Archaeological expressions & $\begin{array}{l}\text { Collective architectures; collective tombs } \\
\text { with a paraphernalia of ideotechnic artifacts like } \\
\text { occulated idols. E.g. tholoi of Olival da Pega, walled } \\
\text { and ditched enclosures (Porto das Carretas I, S. } \\
\text { Brás, San Blas, Perdigões, Pijotilla, Alcalar). }\end{array}$ & $\begin{array}{l}\text { Elaborate prestige goods in individual graves; } \\
\text { Extended production and standardization of } \\
\text { prestige goods like arsenic copper weapons, } \\
\text { gold ornaments, ivory buttons and Bell Beaker } \\
\text { pottery. E.g. hoard of S. Brás; reuse of ancestors } \\
\text { funerary monuments like the hipogea cemeter- } \\
\text { ies of Quinta do Anjo, S. Pedro do Estoril or } \\
\text { Dolmen da Pedra Branca; power architecture as } \\
\text { the towers of Porto das Carretas II, Monte da } \\
\text { Tumba IV, Miguéns } 3 \text {. }\end{array}$ \\
\hline
\end{tabular}

Figure 7. Socio-economic dynamics in the 3rd millennium cal BC of the Iberian Southwest (after Soares 2013a).

By the end of the millennium the abandonment process of these agglomerations becomes evident, replaced by a spectrum of social fission dynamics, with increasing dispersion of open and small settlements (with incised Bell Beaker pottery of Ciempozuelos and evolved Palmela styles), such as Barrada do Grilo (Santos, Soares and Tavares da Silva 1972), Castelos do Torrão (Soares and Tavares da Silva 1986), Vale Vistoso (Soares and Tavares da Silva 1976-77), and Quinta do Estácio 14 (Soares 2017) in Alentejo. The same phenomenon has been observed in Estremadura (Soares 2003; Sousa 2013; Tavares da Silva 2017). Unstable political power, as already proposed, seems to be controlled by skilled leaders who were also managing the chaînes opératoires of metallurgy and textile craftwork (Barber 1991; Murra 1962; Soares et al. 2018). This new economic sector (not regulated by the traditional peasant society) could have been the driving factor in the constitution of elites progressively consolidated by heredity after $1500 \mathrm{cal} \mathrm{BC}$ in southwest Bronze Age societies (Soares and Tavares da Silva 2016).

The subsistence economy was mostly based on cereals and livestock (Sus sp., Bos taurus, Ovis aries/Capra hircus), and millstones were better represented in Phase II of Porto das Carretas than in Phase I (Soares 2013a: table 33), which can indicate that the local elite might have been receiving tribute from peasant households. The increase in hunting for larger species is remarkable, namely Cervus elaphus and Bos primigenius ('aristocratic hunting' with Canis familiaris), as observed at the Bell Beaker occupation site of Monte da Tumba in the Middle Sado Basin (Antunes 1987: 125). The same trend occurred with riverine fishing, with evidence of a 


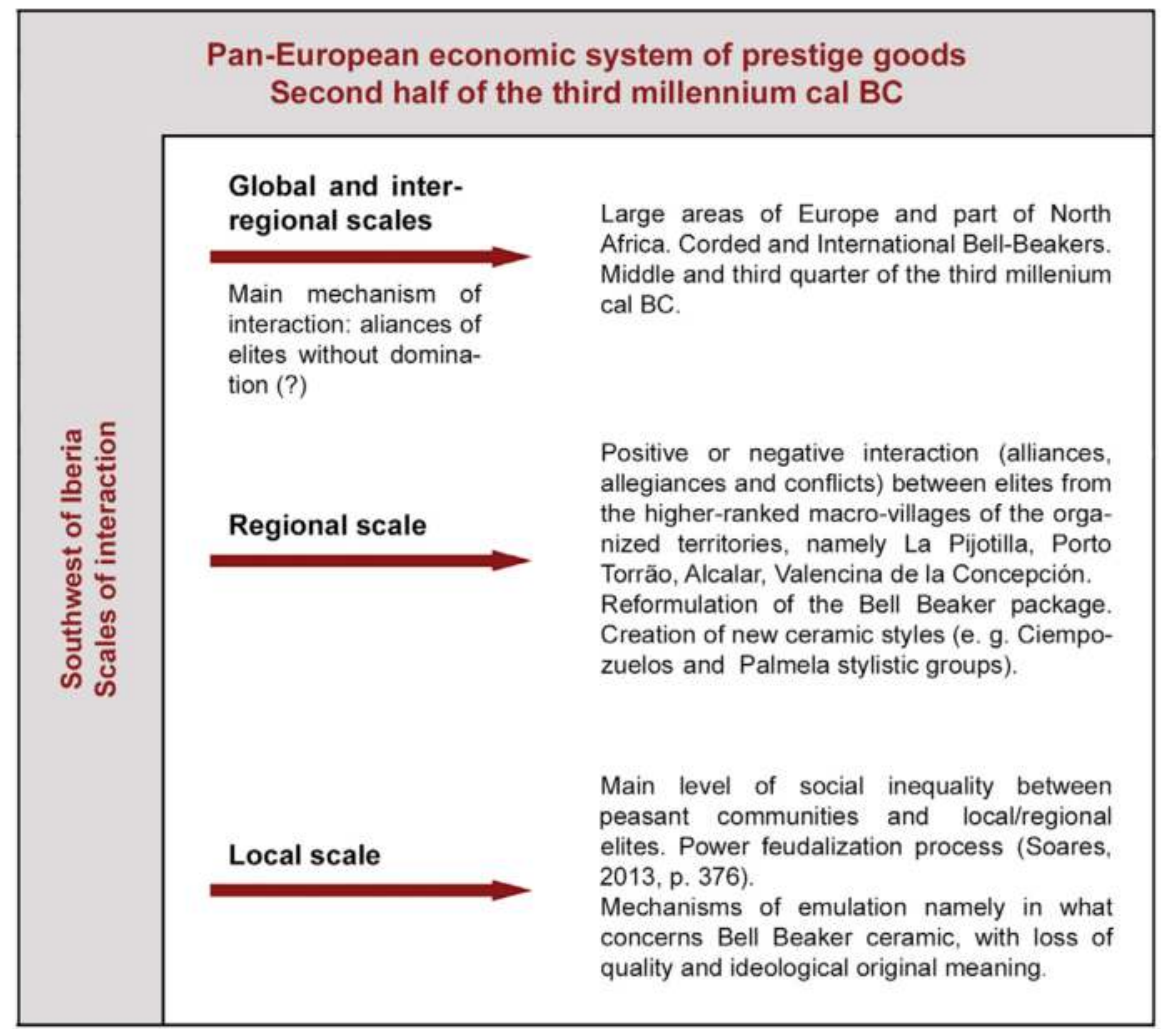

Figure 8. Outline of the main interaction scales during the second half of the $3 \mathrm{rd}$ millennium in the Iberian Southwest (after Soares 2016).

complete fishing net found in tower M13 of Porto das Carretas (Soares 2013a: table 20). Weaving activity also seems to have reached a peak of development (Soares et al. 2018). The typology of loom weights (crescentes), and the high quality of linen revealed by a painted fragment of linen from the necropolis of Belle France in Algarve, directly dated to the middle-third quarter of the 3rd millennium (Soares et al. 2018: Figure 17), illustrate the technological development of weaving in southern Portugal, a region that may have been at an advantage compared to other parts of Portugal (Cardito Rollán 1996).

In synthesis, striking social changes took place in the third quarter of the 3rd millennium cal BC (Phase II of Porto das Carretas). The complex tribal organisation of the first half of the 3rd millennium was exhausted, probably due to excessive territorial and social segmentation, which blocked the development of productive forces (craft activities of weaving and metallurgy, and trade). In the second half of the 3rd millennium cal BC, we find evidence of an unstable politic power, still without capacity for hereditary perpetuation, which fits well with the anthropological concept of chiefdom (Carneiro 1981; Kipp and Schortman 1989; Kristiansen 1991; Service 1962).

A new socio-political organisation emerges from the wreckage of the precedent, polarised by personalised leaderships: adventurers, holders of the control of the production and circulation of arsenic copper artefacts, namely weapons, gold and ivory sociotechnic artefacts (Schuhmacher et al. 2009), textiles, and other prestigious goods. The accumulation of socially recognised wealth guaranteed these individuals the capacity to organise supportive factions and labour force reserves, thus creating a new kind of social relations in terms of production (vassalage /feudalisation), different from the traditional lineage structure. Primary subsistence production would hypothetically continue to be secured by peasant communities with direct access to the land; the extraction of surplus value from the labour force involved in production would be carried out by Beaker elites within the framework of the economic power of symbols (Lash and Urry 1999; Soares 2003) and in the context of an emergent warrior ideology, as mechanisms of wealth accumulation. The social division of labour, a prerequisite for social stratification, can now begin its development outside the rigid Chalcolithic tribal organisation. The archaeological record reveals not only widespread dissemination by the vast majority of habitats of copper smelting practices on a domestic scale, but in parallel shows the existence of an integrated metallurgical specialisation crossing the whole Iberian Peninsula, both in the sources of supply, for example in underground mines (Blas Cortina and Suárez Fernandéz 2009), in small open-air mining camps (Montero Ruiz and Rodríguez de la Esperanza 
2008), and at stable mining sites, such as Cortadouro (Tavares da Silva and Soares 1976-1977) and Cabezo Juré (Sáez et al. 2003; Nocete et al. 2006), or in functionally specialised spaces inside macro-villages, such as at Valencina de la Concepción (Nocete et al. 2008) and San Blas (Hunt et al. 2009; Hurtado Pérez 2004: 153).

The main changes that occurred in the second half of the 3rd millennium cal BC in the Middle Guadiana Basin, compared to the previous Chalcolithic complex tribal society, can be listed as the following (Figure 7):

1. Development of arsenic copper metallurgy and textile manufacturing $->$ gains of productivity.

2. Development of exchange networks. Production and consumption of standardised prestige commodities: metallic weapons, ivory buttons, fine textiles, Bell Beaker pottery $\rightarrow$ fluidity of territorial boundaries.

3. Weakening of kinship relations versus strengthening of residential solidarities.

4. Power centralisation + knowledge-based political economy linked to personalised leaderships, integrated into extended exchange networks of prestige goods (D'Altroy and Earle 1985; Earle 1999; Clark and Blake 1999; Guyer and Belinga 1995; Soares 2013a) -> unstable and 'omniscient' leaderships based on the control of esoteric and ecological knowledge systems; use of rhetoric heritage accounts (Lash and Urry 1999; Graham, Ashworth, Tunbridge 2000; Soares 2013a: 6970 and 386-388) -> individual appropriation of wealth.

5. Intensification of the social division of labour -> (Soares 2008; 2013a; 2016) -> managerial activities $\rightarrow$ political leadership.

6. Death of the 'sun eyes' Chalcolithic divinities 'occulated idols'- replaced by symbols of warrior and heroic ideologies.

Thus it was the onset of a new socio-political organisation with a vertical structure, increasingly personalised in its representation. Insofar as this process advanced, the old world of tribal societies and the correlated communitarian ideology were entering into a profound crisis. The collective funerary ritual changed sharply to single grave inhumations, some with rich assets: Palmela copper arrowheads, tanged copper daggers, stone wrist-guards, Bell Beaker vessels, ivory buttons with V-shaped perforation, gold ornaments.

\section{The Early Bronze Age (EBA2): 2200-1800 cal BC}

The radiocarbon chronology of the mega-sites of the Iberian Southwest Chalcolithic demonstrates a very long permanence that began with the Secondary Products Revolution (Sherratt 1983; Soares 2003,
Greenfield, 2010) at the end of the 4th millennium, decayed at 2500 cal BC onwards, and collapsed at c. 2200 cal BC, as observed for example at La Pijotilla (Badajoz). Moving towards the east, at the upper Guadalquivir region, in a semi-periphery of El Argar, the mega-site of Marroquies Bajos (Jaen), of more than 100 ha and with five concentric ditches, underwent a similar sharp transformation, being abandoned at c. 2200-2100 cal $\mathrm{BC}$, 'to be replaced by small farms that testify to the fragmentation of the previous economic collectivism' (Lull et al. 2013: 605).

The EBA elites, who held control of metallic production and its distribution, either in southern or northern Portugal, grasped the right to have coercive means such as fortress-towers and weapons (e.g. the São Brás copper hoard at Serpa, and the single grave of Quinta da Água Branca in Vila Nova de Cerveira) (Soares 2013a: 400-411; Valério et al. 2018; Armbruster and Parreira 1993: 36-39; Fortes 1905-1908).

The regional demographic signature displays a clear reduction at the transition to the 2 nd millennium cal BC. Settlements and domestic architectures became hardly visible in the archaeological record. Currently, archaeological rescue works have been filling the gap, revealing a few open silo-sites of long-lasting peasant communities in southern Portugal, from Chalcolithic to Late Bronze Age (the resilient dimension of continuity), such as Monte da Cabida 3 (Soares et al. 2009) and Casarão da Mesquita 3 (Santos et al. 2008). Additionally, the archaeological record of this period is based mostly on funerary evidence (Table 1): individual burials even if they reuse collective tombs of ancestors (late Ciempozuelos and Palmela beakers, and Ferradeira horizon), such as the dolmen of Pedra Branca - Melides (Ferreira et al. 1975a, 1975b), the hypogea cemeteries of the Lisbon and Setúbal Peninsulas (Soares 2003; Sousa and Gonçalves 2019), the tholoi of Monte da Velha 1 (Soares Monge 2008), Centirã 2 (Henriques et al. 2013), Cardim 6 (Valera et al. 2019), and the single graves of the Ferradeira complex at Guadajira (Hurtado and Garcia Sanjuan 1994), and Bela Vista 5 (Valera 2014).

In the material culture of the Ferradeira complex (southernPortugal), wecanobservea 'dematerialisation' process that will continue during the culture of Southwest Bronze Age I. The showy Bell Beaker pottery lost its decoration and correlated ideological/ communicational functions; on the contrary, the metallic weapons of the Bell Beaker package, namely the Palmela copper arrowhead type had a noteworthy presence in the Ferradeira horizon.

Meanwhile other regions, such as the southeast, experienced a demographic increase and growing cultural activity. In the Iberian southeast a new 


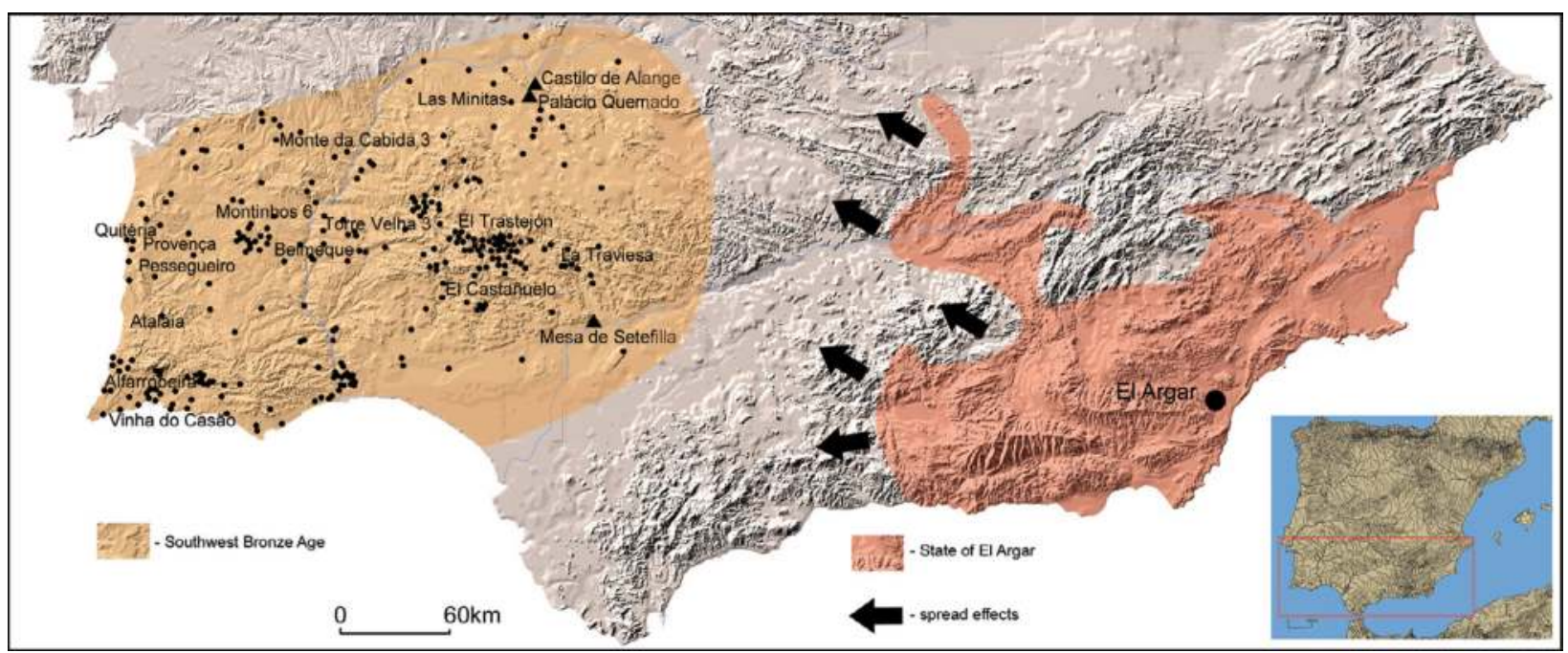

Figure 9. Southern Iberia with the territories of the 'Southwest Bronze Age Culture' (yellow) and El Argar State (red). Locations of the most important achaeological sites of the 'Southwest Bronze Age Culture' (after Soares and Tavares da Silva 2016).

archaeological reality emerges around 2200 cal BC 'unrelated to any Chalcolithic construction' (Lull et al. 2015: 366), dominated by very strong, inaccessible and monumental fortifications: La Bastida, Gatas, Fuente Alamo, El Argar. This politically organised territory corresponds to the early state model (Lull et al. 2005; Cámara and Molina 2011).

\section{At the onset of the Middle Bronze Age (EBA/MBA) (1800- 1500 cal BC)}

After the moment of a probable political disarticulation, to which the neighbouring state of El Argar would have given an important contribution, the sphere of political economy confirms the precedent turn towards its detachment from subsistence economy (Soares 2013a: 431). A probable scenario of short-lived, incipient chiefdoms in the Early Bronze Age evolved slowly into a progressively more vertical hierarchical organisation (along with growing social inequality), but one subjected to fragmentation and weakening by the alleged assaults of El Argar (Soares and Tavares da Silva 2016) (Figure 9).

Taking into account the hypothesis we are defending, by which the Iberian southwest was one of the peripheries subjected to direct or indirect action of the state of El Argar (Soares and Tavares da Silva, 2016), the southwest had been probably affected by exploitation during the Early Bronze Age, likely by looting and destruction of the means of production by El Argar forces, which hindered political centralisation in that region. Chiefs of the extended peripheries of the El Argar territories could have had different agreements with this state, moving at distinct rhythms on emulation, competition increases, and even on the exploitation of their own peripheries. In more favourable conditions, a few chiefdoms might essay mechanisms of power transmission by hereditary. However, in general, social instability created by the strongest neighbour may have been an adverse factor to the reinforcement of political power and consolidation of class society in peripheral/ marginal areas.

Cultural southeast influences beyond El Argar borders are documented in the far southwest mainly in metal production and funerary practices: inhumation of bodies in single containers; proximity and even spatial overlap of residential and funerary functions; rituals of commensality; metallic grave goods in arsenic copper, bronze, silver and gold (Valério et al. 2019), as well as greenstone beads (Odriozola et al. 2016). However, the distance/resistance may have avoid the mischaracterisation of the southwest cultural profile.

The slow cycle of development of the Southwest Bronze Age Culture (SBAC) (Schubart 1975) includes a growing component of social inequality between the early phase, c. $1800 \mathrm{cal} \mathrm{BC}$, and the latter, c. $1200 \mathrm{cal} \mathrm{BC}$, observed namely by the application of the Lorenz curve to funerary data of Algarve (Gomes 1994): cemeteries of Vinha do Casão (SBAC I), Vale da Telha and Alfarrobeira (SBAC II) (Figure 10B). Therefore, at that stage the southwest would have been subject to very asymmetrical power relations, even among intra-social local groups (Tavares da Silva and Soares 2009). The social hierarchy is very well expressed in the typology of habitats, displaying a sharp contrast between:

- Hilltop fortified settlements such as Cerro del Castillo de Alange (Pavón Soldevila 1998; Pavón Soldevila and Duque Espino 2014), Setefilla, 


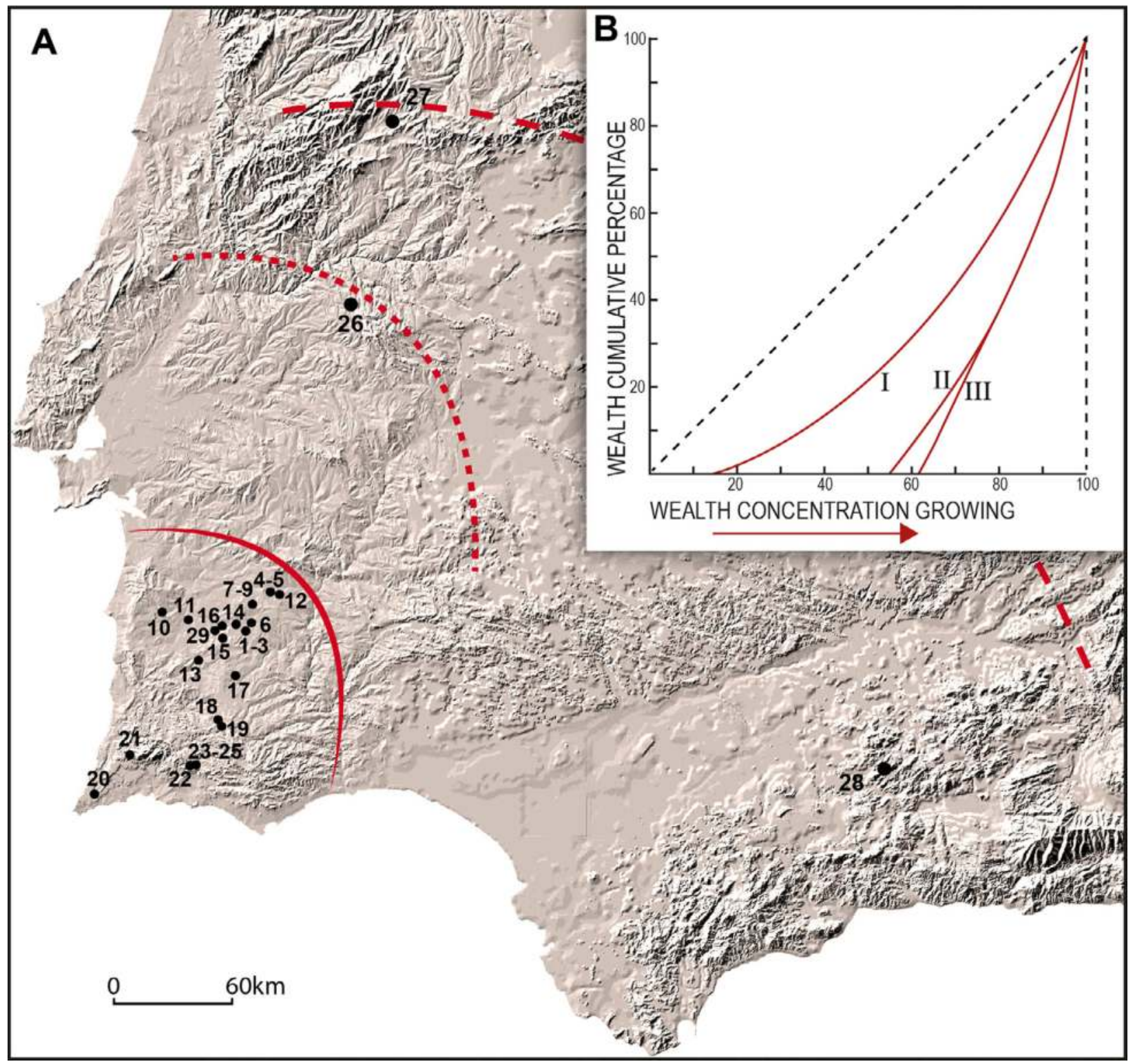

Figure 10. A) Southern Iberia with the distribution of the stelae of Alentejo type, a good indicator of the sociocultural identity of the Southwest Middle Bronze Age: 1) Assento, Santa Vitória (Beja); 2) Pedreirinha, Santa Vitória (Beja); 3) Santa Vitória; 4) Trigaches I (Beja); 5) Trigaches II (Beja); 6) Monte do Ulmo, Santa Vitória (Beja); 7) Mombeja I (Beja); 8) Mombeja II (Beja); 9) Mombeja III (Beja); 10) Abela (Santiago do Cacém); 11) Defesa, Alvalade do Sado (Santiago do Cacém); 12) Monte de Abaixo (Beja); 13) Panóias (Ourique); 14) Ervidel I (Aljustrel); 15) S. Salvador (Aljustrel); 16) S. João de Negrilhos, Messejana (Aljustrel); 17) Castro Verde; 18) Gomes Aires (Almodôvar); 19) Mouriços (Almodôvar); 20) Milrei, Raposeira (Vila do Bispo); 21) Marmelete (Monchique); 22) Alfarrobeira (S. Bartolomeu de Messines); 23) Passadeiras I (S. Bartolomeu de Messines); 24 ) Passadeiras II (S. Bartolomeu de Messines); 25) Passadeiras III (S. Bartolomeu de Messines); 26) Tapada da Moita (Castelo de Vide); 27) Corgas, Donas (Fundão); 28) El Torcal (Córdoba); 29) Carniceira (Aljustrel) (after Soares and Tavares da Silva 2016. B) Lorenz curve, showing the growth of social inequality in the Southwest Bronze Age at Algarve: Vinha do Casão - I (Southwest Bronze Age Culture I), Vale da Telha - II and Alfarrobeira - III (Southwest Bronze Age Culture II) (after Gomes 1994).

Seville, (Aubet et al. 1983), or the terraced site of El Trastejón, Huelva (Hurtado 1990; García Sanjuán, L. and V. Hurtado 2011), probably with political control functions, which were occupied from the Early to Late Bronze Age.

- Open peasant lowland villages, with perishable huts near cist cemeteries, of the far southwest Atlantic coast: Pessegueiro, Provença and
Quitéria in Sines Municipality (Tavares da Silva and Soares 1981; 2009; Soares and Tavares da Silva 1995), Vale da Telha, in Aljezur, the Algarve (Gomes, 2015).

After the decay and collapse of El Argar, around 1400/1375 cal BC (Molina and Camara 2004), the southwest enters a cycle of development, from about 
$1600 / 1500$ to $1200 \mathrm{cal} \mathrm{BC}$, i.e. the full Middle Bronze Age, encompassing the Southwest Bronze Age Culture II (SBACII). There are important innovations, such as the repertoire of fine, dark-coloured pottery inspired by metallic models, and metal-rich weapons as grave goods in hypogea and cist cemeteries, as well as the Alentejo stelae type, a good indicator of the sociocultural identity of the Southwest Middle Bronze Age (Figure 10A). The practice of bronze metallurgy is documented, namely in the settlement of Malhada do Vale da Água, Ferreira do Alentejo, with radiocarbon dates between 1535-1294 cal BC (Valério et al. 2013). This empirical record converges on the hypothesis of the emergence of a proto-state in the Middle Bronze Age, encompassing southern Portugal (Figure 10A), from the Guadiana river to the Atlantic shore, polarised by the region of Beja - the Santa Vitória Cultural Horizon (Soares and Tavares da Silva 2016).

From the Middle Bronze Age (1500-1200 cal BC) onwards, societies in the southwest of the Iberian Peninsula multiply the evidence of trans-Mediterranean interactions, expressed, for example, by the long swords, a characteristic item of Alentejo stelae iconography (Barceló 1991; Díaz-Guardamino 2014; Gomes and Monteiro 1977), and by the Montejícar-style halberds, which seem to follow models of the Creto-Mycenaean circle (Gomes 1994: 122; Buchholz and Karageorghis 1973). This integration into the Mediterranean world will be reinforced in the Late Bronze Age (Ruiz-Gálvez 2009; Vilaça 2011-2012).

\section{Conclusion}

In the first half of the $3 \mathrm{rd}$ millennium cal $\mathrm{BC}$, a complex tribal social formation blossomed in the Middle Guadiana Basin, as observed from the local productive system of the Luz Territory. After 2500 cal BC that Chalcolithic society decays, being replaced by unstable elite networks of Bell Beaker groups. This new unstable hierarchical social model, with vertical organisation integrated within the economic system of prestige goods, spread over most of the European continent.

The Chalcolithic communitarian principles and 'peasants' identities represented by ideological artefacts, such as 'occulated idols', were replaced by symbols of the glorification of specific individuals and their association to a warrior ideology, as expressed in metal weapons and by other sociotechnic artefacts. The commemoration of Beaker leaders will drive onwards to the paramount chiefs of the Middle/Late Bronze Age.

For the late prehistory of the Iberian southwest, the Early Bronze Age represents a deep cultural crisis and political disconnection, with demographic decrease and cultural dematerialisation. In trying to explain this social decline, we highlight the socio-economic dynamics of the Late Chalcolithic and geopolitical factors during the Early Bronze Age: the peripheral position of the southwest in relation to the state of $\mathrm{El}$ Argar.

We are, ultimately, aware of the limitations of the available data in approaching Early Bronze Age societies, dominated by fission dynamics and sociopolitical disarticulation, which hide the trajectories of local and regional changes, as well as Bronze Age settlement strategies.

\section{Acknowledgements}

Thanks are due to the Archaeological Research Centre (CEA) of MAEDS - Museum of Archaeology and Ethnography of the District of Setúbal/AMRS for its support, especially to Carlos Tavares da Silva for his discussions on the subject, and to Barbara Polyak for her English translation. We are also grateful to Susana Lopes and Sérgio Gomes for their invitation to participate at such a stimulating forum, as well as to the anonymous reviewer for her/his careful reading and suggestions and to Gerald Brisch for the final English revision.

\section{References}

Antunes, M.T. 1987. O povoado fortificado calcolítico do Monte da Tumba. IV - Mamíferos (nota preliminar). Setúbal Arqueológica 8: 103-144.

Armbruster, B. and Parreira, R. (eds) 1993. Inventário do Museu Nacional de Arqueologia. Colecção de Ourivesaria. Do Calcolítico à Idade do Bronze 1. Lisboa: Secretaria de Estado da Cultura/Instituto Português de Museus.

Aubet, M.E., Serna, M.R., Escacena, J.L. and Ruiz Delgado, M.M. 1981. La Mesa de Setefilla, Lora del Río (Sevilla). Campaña de 1979. Excavaciones Arqueológicas en España 122. Madrid: Ministerio de Cultura.

Balsera, V., Bernabeu, J.A., Costa-Caramé, M, Dìaz-delRío, P., García Sanjuán, L. and Pardo, S. 2015. The radiocarbon chronology of Southern Spain's Late Prehistory (5600-1000 cal BC): a comparative review. Oxford Journal of Archaeology 34(2): 139-156.

Barber, E.J.W. 1991. Prehistoric textiles: the development of cloth in the Neolithic and Bronze Age with special reference to the Aegean. New Jersey: Princeton University Press.

Barceló, J.A. 1991. El Bronce del Sudoeste y la cronologia de las estelas alentejanas. Arqueologia 21: 15-24. Porto: Grupo de Estudos Arqueológicos do Porto.

Bate, L.F. 2003. Sociedades cazadoras recolectoras y primeros asentamientos agrarios, in Jornadas Temáticas Andaluzas de Arqueología. Resúmenes 1-26. Ronda-Málaga: Junta de Andalucia.

Blanco-González, A., Lillios, K.T., López-Sáez, J.A. and Drake, B.L. 2018. Cultural, demographic and environmental dynamics of the Copper and Early 
Bronze Age in Iberia (3300-1500 BC): towards an interregional multiproxy comparison at the time of the 4.2 ky BP event. Journal of World Prehistory 31: 1-79.

Blas Cortina, M.A. and Suárez Fernández, M. 2009. Unprecedented tools of animal origin in the prehistoric copper mines of La Profunda (León) and their C14 dating (AMS). Zhephyrus 64: 5-18.

Brumfiel, E.M. 1995. Heterarchy and the analysis of complex societies: comments, in R.M. Ehrenreich, C.L. Crumley, J.E. Levy (eds) Heterarchy and the Analysis of Complex Societies: 125-131. Archaeological Papers 6. Arlington: American Anthropological Association.

Buchholz, H.G. and Karageorghis, V. 1973. Prehistoric Greece and Cyprus: an archaeological handbook (trans. F. Garvie). London: Phaidon.

Bueno Ramirez, P., De Balbín Behrmann, R. and Barroso Bermejo, R. 2005. Hiérarchisation et métallurgie: statues armées dans la Péninsule Ibérique. L'Anthropologie 109(4): 577-640.

Bueno Ramírez, P., Barroso Bermejo, R., Balbín Behrmann, R.D. and Salvado, P. 2019. Stone witnesses: armed stelae between the international Tagus and the Douro, Iberian Peninsula. SPAL 28 (2): 143-164.

Calado, M. 2006. Territórios da Pré-história em Portugal. Alentejo. Arkeos 18. Tomar: Centro de Pré-história do Instituto Politécnico de Tomar.

Cámara, J.A. and Molina, F. 2011. Jerarquización social en el mundo Argárico (2000-1300 a. C). Quaderns de prehistòria i arqueologia de Castelló 29: 77-104.

Cardito Rollán, L.M. 1996. Las manufacturas textiles en la Prehistoria: Las placas de telar en el Calcolítico Peninsular. Zephyrus 49: 125-145.

Cardoso, J.L.,Monge Soares, A.M. and Martins, J.M.M. 2013. Moita da Ladra. O Arqueólogo Português 3, S. V: 213-253.

Carneiro, R. 1981. The chiefdom: precursor of the state, in G.D. Jones and R.R. Kautz (eds) The transition to the statehood in the New World: 45-54. Cambridge: Cambridge University Press.

Clark, J.E. and Blake, M. 1999. The power of prestige: competitive generosity and the emergence of rank societies in Lowland Mesoamerica, in R.W. Preucel and I. Hodder (eds) Contemporary Archaeology in Theory. A Reader: 258-281. Oxford: Blackwell Publishers.

Clastres, P. 1974. La société contre l'état. Paris: Les Éditions de Minuit.

Clastres, P. 1987. Investigaciones en antropologia política. Barcelona: Gedisa Editorial.

D'Altroy, T. and Earle, T. 1985. Staple finance, wealth finance, and storage in the Inka political economy. Current Anthropology 25: 187-206.

Díaz-Zorita, M.B. (ed.) 2017. Dossier: new perspectives in the study of bioarchaeological remains from the 3rd millennium BC in southern Iberia. Menga 8: 1287.

Díaz-Guardamino, M. 2014. Shaping social identities in Bronze Age and Early Iron Age western Iberia: the role of funerary practices, stelae, and statuemenhirs. European Journal of Archaeology 17(2): 329349.

Díaz-Guardamino Uribe, M., Wheatley, D.W., Williams, E.F. and Garrido Cordero, J.Á. 2016 Los textiles elaborados con cuentas perforadas de Montelirio, in Á. Fernández Flores, L. García Sanjuán and M. DíazZorita Bonilla (eds) Montelirio. Un gran monumento megalítico de la Edad del Cobre: 345-364. Seville: Junta de Andalúcia.

Duque Espino, D.M. 2004. La gestión del paisaje vegetal en la Prehistoria Reciente y Protohistoria en la Cuenca Media del Guadiana a partir de la antracología (tese doutoral). Cáceres: Universidade de Extremadura.

Earle, T.K. 1991. Property rights and the evolution of chiefdoms, in T. Earle (ed.) Chiefdoms: Power, Economy and Ideology: 71-99. Cambridge: Cambridge University Press.

Earle, T.K. 1999. Specialization and the production of wealth: Hawaiian chiefdoms and the Inka Empire, in R.W. Preucel and I. Hodder (eds) Contemporary Archaeology in Theory. A Reader: 165-188. Oxford: Blackwell Publishers Ltd.

Ferreira, O. da V., Zbyszewski, G., Leitão, M., North, C.T., and de Sousa, H.R. 1975a. A contribuição do 'agro setubalense' para o conhecimento da cultura do vaso campaniforme em Portugal. Setúbal Arqueológica 1: 45-51.

Ferreira, O. da V., Zbyszewski, G., Leitão, M., North, C.T., and de Sousa, H.R. 1975b. Le Monument mégalithique de Pedra Branca auprès de Montum (Melides). Comunicações dos Serviços Geológicos de Portugal 59: 107-192.

Fitzpatrick, A. 2009. In his hands and in his head: the Amesbury Archer as a metalworker, in P. Clark (ed.) Bronze Age Connections. Cultural contact in Prehistoric Europe: 176-188. Oxford: Oxbow Books.

Fortes, J. 1905-1908. A sepultura da Quinta da Água Branca. Portugalia II: 241-252.

Fried, M. 1967. The evolution of political society: an essay in political anthropology. New York: Random House.

Friedman, J. and Rowlands, M. 1982. Notes towards an epigenetic model of the evolution of 'civilisation', in J. Friedman and M. Rowlands (eds) The evolution of social systems: 201-276. Pittsburgh: Institute of Archaeology.

Furholt, M. 2019. Re-integrating archaeology: a contribution to a DNA studies and the migration discourse on the 3rd millennium BC in Europe. Proceedings of the Prehistoric Society 85: 115-129.

Gailey, C.W. and Patterson, T.C. 1988. State formation and uneven development, in J. Gledhull, B. Bender, M.T. Larsen (eds) State and Society: The emergence 
and development of social hierarchy and political centralization: 77-90. London: Routledge.

García Sanjuan, L. 2013. El asentamiento de la Edad del Cobre de Valencina de la Concepción: estado actual de la investigación, debates y perspectivas, in $\mathrm{L}$. García Sanjuan, J.M. Vargas Jiménez, V. Hurtado Pérez, T. Ruiz Moreno and R. Cruz-Auñón Briones (eds) El asentamiento prehistórico de Valencina de la Concepción (Sevilla): 21-59. Sevilla: Universidad de Sevilla.

García Sanjuán, L. and Hurtado, V. 2011. Las dataciones radiocarbónicas de El Trastejón en el marco de la cronologia absoluta de la Edad del Bronce (c. 2200850 cal A.N.E.) en el Sur de la Península Ibérica, in V. Hurtado, L. García Sanjuán and M.A. Hunt Ortiz (eds) El asentamiento de El Trastejón (Huelva): 138-157. Huelva: Junta de Andalucía, Consejería de Cultura.

García Sanjuan, L., Cintas-Peña, M., Bartelheim, M. and Luciañez Triviño, M. 2018a. Defining the 'elites': a comparative analysis of social ranking in Copper Age Iberia, in H. Meller, D. Gronenborn and R. Risch (eds) Überschuss ohne Staat - Politische Formen in der Vorgeschichte/Surplus without the State Political Forms in Prehistory: 311- 333. Tagungen des Landesmuseums für Vorgeschichte Halle, Band 18. Halle (Saale): Landesmuseum für Vorgeschichte.

García Sanjuan, L., Vargas Jiménez, J.M., Cáceres Puro, L.M., Costa Caramé, M.E., Díaz-Guardamino Uribe, M., Díaz-Zorita Bonilla, M., Fernández Flores, Á., Hurtado Pérez, V., López Aldana, P.M., Méndez Izquierdo, E., Pajuelo Pando, A., Rodríguez Vidal, J., Wheatley, D., Ramsey, C.B., Delgado-Huertas, A., Dunbar, E., Mora González, A., Bayliss, A., Beavan, N., Hamilton, D., Whittle, A. 2018b. Assembling the dead, gathering the living: radiocarbon dating and Bayesian modelling for Copper Age Valencina de la Concepción (Seville, Spain). Journal of World Prehistory 31: 179-313.

Gilman, A. 1981. The development of social stratification in Bronze Age Europe. Current Anthropology 22: 1-23.

Gomes, M.V. 1994. A Necrópole de Alfarrobeira (S. Bartolomeu de Messines) e a ldade do Bronze no Concelho de Silves. Silves: Câmara Municipal de Silves.

Gomes, M.V. 2015. The Vale da Telha necropolis (Aljezur) in the context of the Southwest Iberian Bronze Age. Lisboa: Instituto de Arqueologia e Paleociências da Universidade Nova de Lisboa.

Gomes, M.V. and Monteiro, J.P. 1977. As estelas decoradas da Herdade de Pomar (Ervidel, Beja). Estudo Comparado. Setúbal Arqueológica 2-3: 281343. Setúbal: Museu de Arqueologia e Etnografia do Distrito de Setúbal.

Gonçalves, V.S., Sousa, A.C., Andrade, M.A. 2017. O Barranco do Farinheiro (Coruche) e a presença Campaniforme na margem esquerda do Baixo Tejo, in V.S. Gonçalves (ed) Sinos e Taças. Junto ao Oceano e mais longe. Aspectos da presença campaniforme na Península Ibérica: 98-125. Estudos \& Memórias 10.
Lisboa: Centro de Arqueologia da Universidade de Lisboa.

Gonçalves, V. S., Sousa, A. C., Santos, M. 2018. A necrópole de grutas artificiais do Casal do Pardo. (Quinta do Anjo, Palmela). 3200-2000 anos antes da nossa era. Um guia curto e alguns comentários. Palmela: Câmara Municipal de Palmela.

Graham, B., Ashworth, G.J. and Tunbridge, J.E. 2000. A Geography of Heritage. London: Arnold.

Greenfield, H.J. 2010. The Secondary Products Revolution: the past, the present and the future. World Archaeology 42(1): 29-45.

Guyer, J.I. and Eno Belinga, S.M. 1995. Wealth in people as wealth in knowledge: accumulation and composition in Equatorial Africa. Journal of African History 36(1): 91-120.

Hayden, B. 1995. Pathways to power. Principles for creating socioeconomic inequalities, in T.D. Price and G.M. Feinman (eds) Foundations of Social Inequality: 15-86. New York: Plenum Press.

Henriques, F.R., Soares, A.M., António, T.F., Curate, F., Valério, P., and Rosa, S. 2013. O tholos Centirã 2 (Brinches, Serpa): construtores e utilizadores; práticas funerárias e cronologias, in J. Jiménez Ávila, M. Bustamante Álvarez and M. García Cabezas (eds) Actas del VI Encuentro de Arqueología del Suroeste Peninsular: 319-55. Villafranca de los Barros: Ayuntamiento.

Heyd, V. 2017. Kossinna's smile. Antiquity 91(356): 348359, https://doi.org/10.15184/aqy.2017.21

Hunt Ortiz, M.A., Hurtado Pérez, V., Montero Ruíz, I., Rovira Llorens, S., and Santos Zalduegui, J.F. 2009. Chalcolithic metal production and provenance in the site of San Blas (Cheles, Badajoz, Spain), in 2nd International Conference of Archaeometallurgy in Europe: 81-92. Milano: Associazione Italiana di Metallurgia.

Hurtado Pérez, V. 1990. Excavaciones en el yacimiento de El Trastejón (Zufre, Huelva). Primera campaña, 1988. Informe preliminar. Anuario Arqueológico de Andalucía/1988 2: 158-164. Sevilha: Junta de Andalucía.

Hurtado Pérez, V. 2004. El asentamiento fortificado de San Blas (Cheles, Badajoz). III milenio AC. Trabajos de Prehistoria 61(1): 141-155.

Hurtado Pérez, V. 2010. The ditched enclosures of the Middle Guadiana basin, in L. Oosterbeek (ed) Proceedings of the XV UISPP World Congress: 109-122. British Archaeological Reports International Series 2124. Oxford: Archaeopress.

Hurtado Pérez, V. and García Sanjuan, L. 1994. La necrópolis de Guadajira (Badajoz) y la transición a la Edad del Bronce en la cuenca media del Guadiana. Spal 3: 95-144.

Kipp, R.S. and Schortman, E.M. 1989. The political impact of trade in chiefdoms. American Anthropologist 91 (2): 
370-385. New Hampshire: American Anthropological Association.

Kristiansen, K. 1991. Chiefdoms, states and systems of social evolution, in T. Earl (ed.) Chiefdoms, Power, Economy and Ideology: 16-43. Cambridge: Cambridge University Press.

Kristiansen, K., Allentoft, M.E., Frei, K.M., Iversen, R., Johannsen, N.N., Kroonen, G., Pospieszny, L., Douglas Price, T., Rasmussen, S., Sjögren, K.-G., Sikora, M., Willerslev, E. 2017. Re-theorising mobility and the formation of culture and language among the Corded Ware Culture in Europe. Antiquity (91) 356: 334-347, https://doi.org/10.15184/aqy.2017.17

Kunst, M., Arnold, F. 2011. Sobre a reconstrução de estruturas defensivas do Calcolítico da Península Ibérica com base na Torre B de Zambujal (Torres Vedras, Lisboa). O Arqueólogo Português 1, S. V: 429488.

Lash, S. and Urry, J. 1999. Economies of signs and space. London: Sage Publications.

Ling, J., Earle, T., Kristiansen, K. 2018. Maritime mode of production. Raiding and trading in seafaring chiefdoms. Current Anthropology 59(5): 488-524.

Lull, V., R. Micó, C. Rihuete Herrada and R. Risch 2005. Property relations in the Bronze Age of Southwestern Europe: an archaeological analysis of infant burials from El Argar (Almeria, Spain). Proceedings of the Prehistoric Society 71: 247-268.

Lull, V., Micó, R., Rihuete Herrada, C., and Risch, R. 2013. Bronze Age Iberia, in H. Fokkens and A. Harding (eds) The European Bronze Age: 594-616. Oxford University Press.

Lull, V., Micó, R., Rihuete Herrada, C. and Risch, R. 2015. Transition and conflict at the end of the $3 \mathrm{rd}$ millennium BC in south Iberia, in H.H. Meller, H.W. Arz, R. Jung and R. Risch (eds) 2200 BC - a climatic breakdown as a cause for the collapse of the old world?: 365-407. Mitteldeutscher Archäologentag, vom 23, bis 26. Halle: Landesmuseum für Vorgeschichte.

Márquez, J.E. 2003. Recintos Atrincherados (RPA) en Andalucía (España): Una propuesta interpretativa, in S. Oliveira Jorge (ed.) Recintos murados da PréHistoria Recente: 269-285. Porto-Coimbra: University of Porto.

Martinón-Torres, M. and Killick, D. 2015. Archaeological theories and archaeological sciences. The Oxford Handbook of Archaeological Theory: 1-17. Oxford Handbooks Online. Oxford: Oxford University Press.

Mataloto, R. and Boaventura, R. 2009. Entre vivos e mortos nos IV e III milenios a.n.e. do Sul de Portugal: um balanço relativo do povoamento com base em datações pelo radiocarbono. Revista Portuguesa de Arqueologia 12(2): 31-77.

Meller, H., Arz, H.W., Jung, R. and Risch, R. (eds) 2015. 2200 BC - A climatic breakdown as a cause for the collapse of the old World?: 9-24. Halle: Landesmuseum für Vorgeschichte.
Molina, F. and Cámara, J.A. 2004. Urbanismoe fortificaciones en la cultura de El Argar. Homogeneidad y patrones regionales, in La Península Ibérica en el II milénio a. C: poblados y fortificaciones: 9-56. Cuenca: Universidad Castilla-La Mancha.

Montero Ruíz, I. and Rodríguez de la Esperanza, M.J. 2008. Un pequeño campamento minero de la Edad del Bronce: La Loma da la Tejeria (Albaracín, Teruel). Trabajos de Prehistoria 65(1): 155-168.

Morán, E. 2014. El asentamiento prehistórico de Alcalar (Portimão, Portugal). La organización del territorio y el proceso de formación de un estado prístino en el tercer milenio a.n.e. PhD thesis presented at University of Sevilla, Faculty of Geography and History, Department of Prehistory and Archaeology.

Murra, J.V. 1962. Cloth and its function in the Inka state. American Anthropologist 64: 710-728.

Nocete, F., Nieto, J.M., Inácio, N., Bayona, M., Sáez, R. and Lizcano, R. 2006. A petrographic contribution to the study of Bell Beaker Phenomena in Southwest Iberia: the case of Cabezo Juré (Huelva, Spain). Resumos do XV Congresso da UISPP: 449. Lisbon: University of Lisbon.

Nocete, F., Queipo de Llano, G., Sáez, R., Nieto, J.M., Inácio, N., Rodríguez Bayona, M., Peramo, A., Vargas Jiménez, J.M., Cruz-Auñon Briones, R., GillIbarguchi, J.L. and Santos, J.F. 2008. The smelting quarter of Valencina de la Concepción (Seville, Spain): the specialised copper industry in a political centre of the Guadalquivir Valley during the third millennium BC (2750-2500). Journal of Archaeological Science 35: 717-732.

Odriozola, C.P., Soares, J., Tavares da Silva, C. and Fonseca, P. 2016. Iberian Southwest Middle Bronze Age. Reading social complexity in greenstone beads from the cist necropolis of Sines, in J. Soares (ed.) Social complexity in a long term perspective: 131152. Setúbal Arqueológica 16. Setúbal: Museu de Arqueologia e Etnografia do Distrito de Setúbal.

Olalde, I., Brace, S., Allentoft, M.E., Armit, I., Kristiansen, K., Rohland, N., Mallick, S., Booth, T., SzécsényiNagy, A., Mittnik, A., Altena, E., Lipson, M., Lazaridis, I., Patterson, N., Broomandkhoshbacht, N., Diekmann, Y., Faltyskova, Z., Fernandes, D., Ferry, M., Harney, E., De Knijff, P., Michel, M., Oppenheimer, J., Stewardson, K., Barclay, A., Alt, K.W., Avilés Fernández, A., Bánffy, E., BernabòBrea, M., Billoin, D., Blasco, C., Bonsall, C., Bonsall, L., Allen, T., Büster, L., Carver, S., Castells Navarro, L., Craig, O.E., Cook, G.T., Cunliffe, B., Denaire, A., Dinwiddy, K.E., Dodwell, N., Ernée, M., Evans, C., Kuchařík, M., Farré, J.F., Fokkens, H., Fowler, C., Gazenbeek, M., Garrido Pena, R., Haber-Uriarte, M., Haduch, E., Hey, G., Jowett, N., Knowles, T., Massy, K., Pfrengle, S., Lefranc, P., Lemercier, O., Lefebvre, A., Maurandi, J.L., Majó, T., McKinley, J.I., McSweeney, K., Gusztáv, M.B., Modi, A., Kulcsár, G., Kiss, V., 
Czene, A., Patay, R., Endrődi, A., Köhler, K., Hajdu, T., Cardoso, J.L., Liesau, C., Pearson, M. P., Włodarczak, P., Price, T.D., Prieto, P., Rey, P.-J., Ríos, P., Risch, R., Rojo Guerra, M.A., Schmitt, A., Serralongue, J., Silva, A.M., Smrčka, V., Vergnaud, L., Zilhão, J., Caramelli, D., Higham, T., Heyd, V., Sheridan, A., Sjögren, K.-G., Thomas, M.G., Stockhammer, P.W., Pinhasi, R., Krause, J., Haak, W., Barnes, I., LaluezaFox, C. and Reich, D. 2018. The Beaker phenomenon and the genomic transformation of northwest Europe. Nature 555(7695): 190-196. http://dx.doi. org/10.1101/135962

Olalde, I., Mallick S., Patterson, N., Rohland, N., VillalbaMouco, V., Silva, M., Dulias, K., Edwards, C.J., Gandini, F., Pala, M., Soares, P., Ferrando-Bernal, M., Adamski, N., Broomandkhoshbacht, N., Cheronet, O., Culleton, B.J., Fernandes, D., Lawson, A.M., Mah, M., Oppenheimer, J., Stewardson, K., Zhang, Z., Jiménez Arenas, J.M., Toro Moyano, I.J., Salazar-García, D.C., Castanyer, P., Santos, M., Tremoleda, J., Lozano, M., García Borja, P., Fernández-Eraso, J., MujikaAlustiza, J.A., Barroso, C., Bermúdez, F.J.,Viguera Minguez, E., Burch, J., Coromina, N., Vivó, D., Cebrià, A., Fullola, J.M., García-Puchol, O., Morales, J.I., Xavier Oms, F., Majó, T., Vergès, J.M., DíazCarvajal, A., Ollich-Castanyer, I., López-Cachero, F.J., Silva, A.M., Alonso-Fernández C., Delibes de Castro, G., Jiménez Echevarría, J., Moreno-Márquez, A., Pascual Berlanga, G.†, Ramos-García, P., RamosMuñoz, J., Vijande Vila, E., Aguilella Arzo, G., Esparza Arroyo, A., Lillios, K.T., Mack, J., Velasco-Vázquez, J., Waterman, A., Benítez de Lugo Enrich, L., Benito Sánchez, M., Agustí, B., Codina, F., De Prado, G., Estalrrich, A., Fernández Flores, A., Finlayson, C., Finlayson, G., Finlayson, S., Giles-Guzmán, F., Rosas, A., Barciela González, V., García Atiénzar, G., Hernández Pérez, M.S., Llanos, A., Carrión Marco, Y., Collado Beneyto, I., López-Serrano, D., Sanz Tormo, M.†, Valera, A.C., Blasco, C., Liesau, C., Ríos, P., Daura, J., De Pedro Michó, M.J., Diez-Castillo, A.A., Flores Fernández, R.†, Francès Farré, J., Garrido-Pena, R., Gonçalves, V.S., Guerra-Doce, E., Mercedes HerreroCorral, A., Juan-Cabanilles, J., López-Reyes, D., McClure, S.B., Merino Pérez, M., Oliver Foix, A., Sanz Borràs, M., Sousa, A.C., Vidal Encinas, J.M., Kennett, D.J, Richards, M.B., Alt, K.W., Haak, W., Pinhasi, R., Lalueza-Fox, C. and Reich, D. 2019. The genomic history of the Iberian Peninsula over the past 8000 years. Science 363: 1230-1234.

Pajuelo Pando, A. and López Aldana, P. 2016. Prestige indicators and Bell Beaker ware at Valencina de la Concepción (Sevilla, Spain), in E. Guerra Doce and C. Liesau (eds) Analysis of the economic foundations supporting the social supremacy of the beaker groups. Proceedings of the XVII UISPP World Congress (1-7 September, Burgos, Spain) 6 (B36): 55-68. Oxford: Archaeopress.
Parreira, R. 1983. O Cerro dos Castelos de S. Brás (Serpa). Relatório Preliminar dos Trabalhos Arqueológicos de 1979 e 1980. O Arqueólogo Português 1, S. IV: 149168.

Pavón Soldevila, I. 1998. El Cerro del Castillo de Alange (Badajoz). Memorias de Arqueologia Extremeña 1. Mérida: Junta de Extremadura.

Pavón Soldevila, I., Duque Espino, D.M. 2014. 40 años de Bronce del Suroeste: aportaciones desde su periferia extremeña. Revista de estudios extremeños LXX: 35-66.

Queiroz, P.F. and Tereso, J.P. 2013. Estudos de arqueobotânica do povoado do Porto das Carretas, Mourão, in J. Soares Transformações sociais durante o III milénio AC no Sul de Portugal. O povoado do Porto das Carretas: 488-500. Lisboa: EDIA, DRCAL and MAEDS.

Ríos, P. 2013. New dating of the Bell Beaker Horizon in the region of Madrid, in M.P. Prieto Martínez and L. Salanova (eds) Current researches on Bell Beakers. Proceedings of the 15th International Bell Beaker Conference: From Atlantic to Ural: 97-110. Santiago de Compostela: Galician ArchaeoPots: wikipot.com.

Ríos, P., Blasco, C. and Aliaga, R. 2011-2012. Entre el Calcolítico y la Edad del Bronce. Algunas consideraciones sobre la cronología campaniforme. CUPAUAM - Cuadernos de Prehistoria y Arqueología 3738: 195-208.

Risch, R., Meller, H., Arz, H.W. and Jung, R. 2015. Preface of the editors, in H. Meller, H.W. Arz, R. Jung and R. Risch (eds) 2200 BC - A climatic breakdown as a cause for the collapse of the old world?: 9-24. Halle: Landesmuseums für Vorgeschichte.

Ruiz-Gálvez Priego, M. 2009. Qué hace un micénico como tú en un sítio como éste? Andalucía entre el colapso de los palacios y la presencia semita. Trabajos de Prehistoria. 66(2): 93-118.

Sahlins, M. 1963. Poor man, rich man, big man, chief: political types in Melanesia and Polynesia. Comparative Studies in Society and History 5: 285-303.

Salanova, L. 2004. Le rôle de la façade atlantique dans la genèse du Campaniforme en Europe. Bulletin de la Société Préhistorique Française 101(2): 223-226.

Sangmeister, E. and Schubart, H. 1981. Zambujal. Die Grabungen 1964 bis 1973. Madrider Beiträge 5, 1. Mainz: Verlag Philipp von Zabern.

Sáez, R., Nocete, F., Nieto, J.M., Capitan, M.A. and Rovira, S. 2003. The extractive metallurgy of copper from Cabezo Jure, Huelva, Spain: chemical and mineralogical study of slags dated to the third millennium BC. The Canadian Mineralogist 41: 627638.

Santos, M.F., Soares, J. and Tavares da Silva, C. 1972. Campaniforme da Barrada do Grilo (Torrão-Vale do Sado). o Arqueólogo Português 6, S. III: 163-192.

Santos, F.J.C., Aréz, L., Monge Soares, A.M., Deus, M., Queiróz, P.F., Valério, P., Rodrigues, Z., Antunes, A.S. and Araújo, M.F. 2008. O Casarão da Mesquita 3 (S. Manços, Évora): um sítio de fossas 'silo' do 
Bronze pleno/ final na encosta do Albardão. Revista Portuguesa de Arqueologia 11(2): 55-86.

Scarre, C. 2013. Social stratification and the State in Prehistoric Europe. The wider perspective, in M. Cruz Berrocal, L. García Sanjuán and A. Gilman Guillén (eds) The Prehistory of Iberia: debating early social stratification and the State: 381-405. Hoboken: Taylor and Francis.

Schubart, H. 1975. Die Kultur der Bronzezeit im Südwester der Iberischen Halbinsel. Madrider Forschungen 9. Berlin: Walter de Gruyter.

Schuhmacher, T.X., Cardoso, J.L. and Banerjee, A. 2009. Sourcing African ivory in Chalcolithic Portugal. Antiquity 83: 983-997.

Service, E.R. 1962. Primitive Social Organization. New York: Random House.

Sherratt, A.G. 1983. The secondary exploitation of animals in the Old World. World Archaeology 15(1): 90-104.

Soares, A. and Monge, M. 2008. O monumento megalítico Monte da Velha 1 (MV1) (Vila Verde de Ficalho, Serpa). Revista Portuguesa de Arqueologia 11(1): 33-51.

Soares, A., Monge, M. and Cabral, J.M.P. 1984. Datas convencionais de radiocarbono para estações arqueológicas portuguesas e a sua calibração. 0 Arqueólogo Português. S. IV (2): 167-214.

Soares, A., Monge, M., Santos, F., Dewulf, J., Deus, M. and Antunes, A. 2009. Práticas rituais do Bronze do Sudoeste. Alguns dados. Estudos Arqueológicos de Oeiras 17: 433-456.

Soares, A., Monge, M., Ribeiro, M.I.M., Oliveira, M.J., Baptista, L., Esteves, L. and Valério, P. 2018. Têxteis arqueológicos pré-históricos do território português: identificação, análise e datação. Revista Portuguesa de Arqueologia 21: 71-82.

Soares, J. 1994. L'habitat fortifé de Monte da Tumba et le Chalcolithique du Sud du Portugal. Les Dossiers d'Archéologie 198: 16-21.

Soares, J. 2003. Os hipogeus pré-históricos da Quinta do Anjo (Palmela) e as economias do simbólico. Setúbal: Museu de Arqueologia e Etnografia do Distrito de Setúbal.

Soares, J. 2008. Economias anfíbias na costa sudoeste ibérica. IV-III milénios BC. O caso da Ponta da Passadeira (estuário do Tejo), in IV Congreso del Neolítico Peninsular T. II: 356-364. Alicante: Museo Arqueológico de Alicante/Diputación Provincial de Alicante.

Soares, J. 2013a. Transformações sociais durante o III milénio AC no Sul de Portugal. O povoado do Porto das Carretas. Lisboa: EDIA, DRCAL and MAEDS.

Soares, J. 2013b. Sal e conchas na Pré-história portuguesa. O povoado da Ponta da Passadeira (estuário de Sado), in J. Soares (ed) Pré-História das Zonas Húmidas. Paisagens de Sal: 171-196. Setúbal Arqueológica 14.

Soares, J. 2016. Social complexity in the third millennium cal $B C$ in southern Portugal, in $\mathrm{J}$.
Soares (ed) Social complexity in a long-term perspective (Setúbal Arqueológica 16): 77-114.

Soares, J. 2017. Para uma leitura sociopolítica do Campaniforme do Guadiana. Longas viagens com curta estada no Porto das Carretas, in V. S. Gonçalves (ed.) Sinos e Taças. Junto ao Oceano e mais longe. Aspectos da presença Campaniforme na Península Ibérica: 39-56. Lisboa: Centro de Arqueologia da Universidade de Lisboa.

Soares, J. and C. Tavares da Silva 1974-77. O Grupo de Palmela no quadro da cerâmica campaniforme em Portugal. 0 Arqueólogo Português 7/9, Série III: 102112.

Soares, J. and C. Tavares da Silva 1976-77. Cerâmica campaniforme de Vale Vistoso (Porto Covo - Sines). Setúbal Arqueológica 2-3: 163-177. Setúbal: Museu de Arqueologia e Etnografia do Distrito de Setúbal.

Soares, J. and Tavares da Silva, C. 1986. Intervenção arqueológica na vila do Torrão. Ocupação calcolítica, in I Encontro Nacional de Arqueologia Urbana (Setúbal 1985): 103-114. Lisboa: Instituto Português do Património Cultural.

Soares, J. and Tavares da Silva, C. 1995. O Alentejo Litoral no contexto da Idade do Bronze do Sudoeste Peninsular, in A Idade do Bronze em Portugal: Discursos de Poder: 136-139. Lisboa: Instituto Português de Museus.

Soares, J. and Tavares da Silva, C. 1998. From the collapse of the Chalcolithic mode of production to the development of the Bronze Age societies in the southwest of Iberian Peninsula, in S. Oliveira Jorge (ed) Existe uma Idade do Bronze Atlântico?: 231-245. Trabalhos de Arqueologia 10. Lisboa: IPA.

Soares, J. and Tavares da Silva, C. 2010. Campaniforme do Porto das Carretas (Médio Guadiana). A procura de novos quadros de referência, in V.S. Gonçalves and A.C. Sousa (eds) Transformação e mudança no Centro e Sul de Portugal: o 40 e o 30 milénios a.n.e.: 225-261. Cascais: Câmara Municipal de Cascais and UNIARQ.

Soares, J. and Tavares da Silva, C. 2016. Bronze Médio do Sudoeste Ibérico. Indicadores de Complexidade Social, in A.C. Sousa, A. Carvalho and C. Viegas (eds) Terra e Água. Escolher sementes, invocar a deusa. Estudos em Homenagem a Victor S. Gonçalves: 359-384. Estudos \& Memórias 9. Lisboa: Centro de Arqueologia da Universidade de Lisboa.

Sousa, A.C. 2013. Casal Cordeiro 5 e o povoamento (com) campaniforme na área da ribeira de Cheleiros, in Arqueologia em Portugal. 150 anos: 469-480. Lisboa: Associação dos Arqueólogos Portugueses.

Sousa, A.C. 2016. Megalitismo e Metalurgia. Os tholoi do Centro e Sul de Portugal, in A.C. Sousa, A. Carvalho, C. Viegas (eds) Terra é Água. Escolher sementes, invocar a Deusa: 209-241. Lisboa: Uniarq.

Sousa, A.C. and Gonçalves, V.S. 2019. Presencia del campaniforme em las cuevas artificiales de las penínsulas de Lisboa y Setúbal, in G. Delibes and E. Doce Guerra (eds) Un brindis por el príncipe! El vaso 
Campaniforme en el interior de la Península Ibérica (25002000 a.C.): 179-206. Madrid: Museo Arqueologico Regional.

Stevenson, A. and Harrison, R. 1992. Ancient forest in Spain: a model for land-use and dry forest management in South-west Spain from 4000 BC to 1900 AD, in Proceedings of the Prehistoric Society 58: 227-247.

Szécsényi-Nagy, A., Roth, C., Brandt,G., RihueteHerrada, C.,Tejedor-Rodríguez, C., Held, P., GarcíaMartínez-de-Lagrán, I., Magallón, H.A., Zesch, S., Knipper, C., Bánffy, E., Friederich, S., Meller, H., Bueno Ramírez, P., Barroso Bermejo, R., De Balbín Behrmann,R., Herrero-Corral, A.M., Flores Fernández, R., Alonso Fernández, C.,Javier Jiménez Echevarria, J., Rindlisbacher, L., Camila Oliart, C., Fregeiro, M.I., Soriano, I., Vicente, O., Micó,R., Lull, V., Soler Díaz, J., López Padilla,J.A. Roca de Togores Muñoz, C., Hernández Pérez, M.S Jover Maestre, F.J., Lomba Maurandi, J., Avilés Fernández, A., Lillios, K.T., Silva,A.M., Ramalho, M.M., Oosterbeek, L.M., Cunha, C., Waterman, A.J., Roig Buxó, J., Martínez, A., Ponce Martínez, J., Hunt Ortiz, M., Mejías-García , J.C., Pecero Espín, J.C., Cruz-Auñón Briones, R., Tomé,T., Carmona Ballestero, E., Cardoso, J.L., Cristina Araújo, A.C., Liesau von Lettow-Vorbeck, C., Blasco Bosqued, C., Ríos Mendoza, P., Pujante, A., Royo-Guillén, J.I., Esquembre Beviá, M.A., Goncalves, V.S., Parreira, R., Morán, E., , Elena Izquierdo, M., Vega y Miguel, J., Menduiña García, R., Martínez Calvo, V., López Jiménez, O., Krause,J., Pichler, S.L., Garrido-Pena, R., Kunst, M., Risch, R., Rojo-Guerra, M.A., Haak, W., and Alt, K.W. 2017. The maternal genetic make-up of the Iberian Peninsula between the Neolithic and the Early Bronze Age. Scientific Reports 7, 15644, doi: https://doi.org/10.1038/s41598-017-15480-9

Tavares da Silva, C. 2017. Entre os estuários do Tejo e do Sado na 2.a metade do III milénio BC: o fenómeno campaniforme, in V.S. Gonçalves (ed) Sinos e Taças. Junto ao Oceano e mais longe. Aspectos da presença campaniforme na Península Ibérica: 142-157. Estudos \& Memórias 10. Lisboa: Centro de Arqueologia da Universidade de Lisboa.

Tavares da Silva, C. and Soares,J.1976-1977. Contribuição para o conhecimento dos povoados calcolíticos do Baixo Alentejo e Algarve. Setúbal Arqueológica 2-3: 179-272.

Tavares da Silva, C. and Soares, J. 1981. Pré-história da Área de Sines. Lisboa: Gabinete da Área de Sines.

Tavares da Silva, C. and Soares, J. 1985. Monte da Tumba (Torrão). Eine Befestigte Siedlung Der Kupferzeit Im Baixo Alentejo. Madrider Mitteilungen 26: 1-21.

Tavares da Silva, C. and Soares, J. 1987. O povoado fortificado calcolítico do Monte da Tumba. I Escavações arqueológicas de 1982-86 (resultados preliminares). Setúbal Arqueológica 8: 29-79.
Tavares da Silva, C. and Soares, J. 2009. Práticas funerárias no Bronze pleno do Litoral Alentejano: o Monumento II do Pessegueiro. Estudos Arqueológicos de Oeiras 17: 389-420.

Tavares da Silva, C. and J. Soares 2014. O Castro de Chibanes (Palmela) e o tempo social do III milénio BC na Estremadura. Setúbal Arqueológica 15: 105-172.

Tereso, J., Queiroz, P., Soares, J. and Tavares da Silva, C. 2011. Charcoal analysis from Porto das Carretas: the gathering of wood and the paleoenvironment context of SE Portugal during the 3rd millennium. Saguntum: Papeles del Laboratorio de Arqueologia de Valencia 11, № Extra: 145-146.

Valera, A.C. 2013. As comunidades agropastoris na margem esquerda do Guadiana (2a metade do IV ao inícios do II milénio AC). Lisboa: EDIA and DRCAL.

Valera, A.C. 2014. Bela Vista 5: um recinto do final do 3ำ milenio a.n.e. (Mombeja, Beja). Era Monográfica 2. Lisboa: NIA-ERA.

Valera, A.C. and Basílio, A.C. 2017. Approaching Bell Beakers at Perdigões enclosures (South Portugal): Site, local and regional scales, in V.S. Gonçalves (ed) Sinos e Taças. Junto ao Oceano e mais longe. Aspectos da presença Campaniforme na Península Ibérica: 82-97. Lisboa: Centro de Arqueologia da Universidade de Lisboa.

Valera, A.C., Figueiredo, M., Lourenço, M., Evangelista, L.S., Basílio, A.C. and Wood, R. 2019. O tholos de Cardim 6. Porto Torrão, Ferreira do Alentejo (Beja). Era Monográfica 3. Lisboa: NIA-ERA.

Valério, P., Baptista, L., Gomes, S., Pinheiro, R., Fernandes, S., Soares, A.M. and Araújo, M.F. 2013. Malhada do Vale da Água: Novos dados sobre a metalurgia do Bronze Pleno no Sudoeste, in Actas VII Encontro de Arqueologia do Sudoeste Peninsular: 575586.

Valério, P., Soares, J., Araújo, M.F., Alves, L.C. and Tavares da Silva, C. 2018. The composition of the São Brás Copper Hoard in relation to the Bell Beaker Metallurgy in the Southwestern Iberian península. Archaeometry 61: 392-405.

Valério, P., Araújo, M.F., Monge Soares, A.M., Soares, J. and Tavares da Silva, C. 2019. Os metais das necrópoles de cistas de Casas Velhas (Melides) e da Provença (Sines). O encontro de antigas e novas tecnologias no Bronze Pleno do Sudoeste, in J. Soares, I.V. Pinto and C. Tavares da Silva (eds) Do Paleolítico ao Período Romano Republicano. Actas do IX Encontro de Arqueologia do Sudoeste Peninsular: 89-96. Setúbal Arqueológica 18. Setúbal: Museu de Arqueologia e Etnografia do Distrito de Setúbal.

Vilaça, R. 2011-2012. Late Bronze Age: Mediterranean impacts in the Western end of the Iberian Peninsula (Actions and Reactions), in M.E. Aubet and P. Sureda (eds) Interacción Social y Comercio en la Antesala del Colonialismo: 13-41. Cuadernos de Arqueología 
Mediterránea 21. Barcelona: Laboratorio de Arqueología de la Universidad Pompeu Fabra.

Waterman, A.J., Tykot, R.H. and Silva, A.M. 2015. Stable isotope analysis of diet-based social differentiation at Late Prehistoric collective burials in southwestern Portugal. Archaeometry: doi: 10.1111/arcm.121.59
Waterman, A.J., Peate, D.W., Silva, A.M and Thomas, J. 2013. In search of homelands: using strontium isotopes to identify biological markers of mobility in late prehistoric Portugal. Journal of Archaeological Science 42: 119-127. 


\title{
Chapter 6
}

\section{'Death in the Occident Express': Social Breakdown in Southwestern Iberia at the End of the 3rd Millennium BC}

\author{
António Carlos Valera \\ Era Arqueologia (antoniovalera@era-arqueologia.pt) / ICArEHB - Algarve University
}

\begin{abstract}
This contribution addresses a problem of periodisation: the transition between the Chalcolithic and the Bronze Age in south Portugal in the late $3 \mathrm{rd}$ millennium BC. This transition corresponds to a breakdown in a path of social complexification developed since the middle of the 4th millennium BC. Four main endogenous systemic variables were selected to discuss their explanatory potential in addressing this breakdown: large scale interaction, investment in monumental forms of ideological display, social emulation, and historical acceleration. The inflated development of these variables is considered to have generated imbalances within the system (namely with the productive subsystem and with social bonds), responsible for the development of systemic fragilities that, by the last quarter of the 3rd millennium BC, would make this social trajectory more vulnerable to eventual external factors, which would act mainly as accelerators of the outcome.
\end{abstract}

Keywords: Transition to Bronze Age, south Portugal, periodisation, monumentality, social interaction.

\section{Introduction: a short conceptual reference for a period of change}

This chapter deals with a problem of historical periodisation, questioning the processes of transition between two sequential social trajectories in prehistoric south Portugal (and in southwestern Iberia in general) at the end of the 3 rd millennium BC. But before entering the discussion we might summarise what is intended by an historical period and what defines its limits.

Social change is not an homogeneous process working in a regular time. It operates in the interactions between subsystems, with arrhythmic velocities generating differential times within historical time. It is the articulation of these different rhythms that leads to the definition of historical periods. A period is, therefore, dependent on the nature and quantity of the variables considered relevant, and which correlation allows the determination of 'moments of historical homogeneity' (Aróstegui 1995): periods where the correlation of relevant variables generates a relatively coherent social trajectory.

Subsequently, the boundaries of a period are related to moments of significant changes involving the wider assemblage of variables within the social scope. Undoubtedly, the nature of archaeological sources may raise problems in the definition of these moments of historical homogeneity and change, for the quantity and quality of information is rarely the same for all the variables of the social system. However, the difficulties should be a warning to use a larger number of variables possible when defining those milestones of change and try to apprehend their rhythmic asymmetries.
To deal with these asymmetries of rhythm and of spatiality it is interesting to recover a concept developed by the historian Vitorino Magalhães Godinho - the 'Historical Geographical Complex' (Complexo Histórico Geográfico) (1955; 1978). The concept was developed precisely to apprehend structural changes, and the arrhythmias and diversity of trajectories within systemic relations in time and space. It brings together time (velocity and rhythm of change) events, interactions, climate, landscapes, and their spatiality, conforming coherent social trajectories within specific spatial relations. It emphasises that the definition of a region is not an historical constant, but something forged in the historical process and which varies according to political, economic, technical, ideological, and cultural factors. As he stated, '[the] idea of region should be relativised, and become historic-anthropogeographic" (Godinho 1946: 28, our translation).

The Iberian Southwest constituted an Historical Geographic Complex, roughly between 3500-3300 and 2200-2000 BC. Spatially speaking, it comprises the lower Guadalquivir valley, the middle Guadiana and Sado basins, and the south coast of Portugal and the Huelva region. Having intra-regional specificities and differences, this area presents a general homogeneous social trajectory and was integrated in large scale interactions with neighbouring regions, such as the Portuguese Estremadura, the central south Meseta, the central and eastern Andalusia, and even regions outside Iberia, such as the north of Africa and central Mediterranean basin. That is why it makes sense to talk about an historical geographical complex referring to this region and its social trajectory during this period, 
because it was involved in a specific network of spatial relations that was different from previous and posterior times. This structural development is aligned with several other Iberian regions between the 4th and 2nd millennia BC. But their temporality and spatial ranges vary, showing historical processes that are related but which present different levels of complexity and outcomes (for the territory of Spain, see Cruz Berrocal et al. 2013; Blanco González et al. 2018).

By the end of the 3rd millennium $\mathrm{BC}$, however, this southwestern area of Iberia shows significant transformations in several variables of the social system that set in train a moment of structural change, with specific regional outcomes.

\section{Signalling an 'Historical Singularity'}

Using another borrowed concept, in this case originated in mathematics to designate points of rupture (and also used to term the moment when the machines will gain consciousness and take over their destinies and ours Ganascia 2018), we may say that by the end of the 3rd millennium $B C$ we have an historical singularity in this region. In fact, the perception of an abrupt change in the southwest is striking, showing a significantly different situation from what can be perceived in the southeast, or even in more northern areas. This is particularly evident in south Portugal, the area within the southwest focused on in this contribution.

What the available archaeological record is showing in this region is a sudden breakdown of a trajectory of social complexification. This trajectory can be followed at least from the third quarter of the 4 th millennium $B C$, or a bit earlier, in the final stages of what is traditionally designated as the Middle Neolithic. And this rupture is a milestone for a periodisation, as, following the criteria presented above, it is recorded simultaneously in multiple variables of the social system (Valera 2015), namely:

- Collapse of large centres of aggregation (Perdigões, Porto Torrão and Alcalar in south Portugal, or Pijotilla, San Blás and Valencina de la Concepción, respectively in Extremadura and western Andalusia).

- Architectonic divestment and drastic reduction of the monumentality in both funerary and non-funerary contexts. End of the enclosure phenomenon.

- Rupture of the interaction networks and of the circulation of valued raw materials and exotic products.

- Disappearance of the diversified iconography and setting of an iconoclastic atmosphere (not in the strict meaning of the word of breaking icons, but in the sense of absence of icons).

- End of the cosmologies founded in the sun cycle, expressed in orientations of structures and iconographic representations.

- Decline of settlement networks and of Neolithic symbolic landscapes, and the emergence of discrete settlements, without significant architectonic investments and 'invisible sites'.

- Substitution of collective and secondary funerary practices and practices of intense manipulation of human remains by individual primary funerary contexts, privileging body integrity, being manipulations discrete or inexistent.

- Signs of growing hunting activity at the cost of herding.

- Significant changes in material culture.

- Signs of demographic decline.

These changes in multiple scopes of social life occur over a relatively short period of time in the last centuries of the 3rd millennium BC, although still with blurred chronological boundaries, and do not configure a situation of progressive transition, but rather a situation of social breakdown.

\section{In search of explanations for a social breakdown}

Several lines of inquiry have been developed to address this problem, but they do not cover all the variables that might have had a significant impact in the outcome of the process. In the present analysis, these variables will be divided into two sets: one regarding the factors considered external to the social relations (briefly mentioning recent published works), and the other corresponding to variables within social relations, where discussion will be more focused.

\subsection{Outside the social relations}

The impact of climatic changes in the late 3rd millennium BC in the collapse of social trajectories has been addressed for many European regions (Weiner 2014; Meller et al. 2015). In Iberia, the regional impact of the aridification $4.2 \mathrm{ka}$ BP event (Mangy et al. 2009; 2013) has been considered in its possible relation with social changes observed in the archaeological record in several regions (Weinelt et al. 2015; Lillios et al. 2016; Blanco-González et al. 2018; Schirrmacher et al. 2020). In south Portugal, the data for climate during the 3rd millennium $B C$ is still relatively scarce, although there is some evidence for a warming tendency along the millennium (Mateus, Queiroz 2000; Espino 2004; Fletcher et al. 2007). But a direct relation between the episodes of significant climatic changes and social 


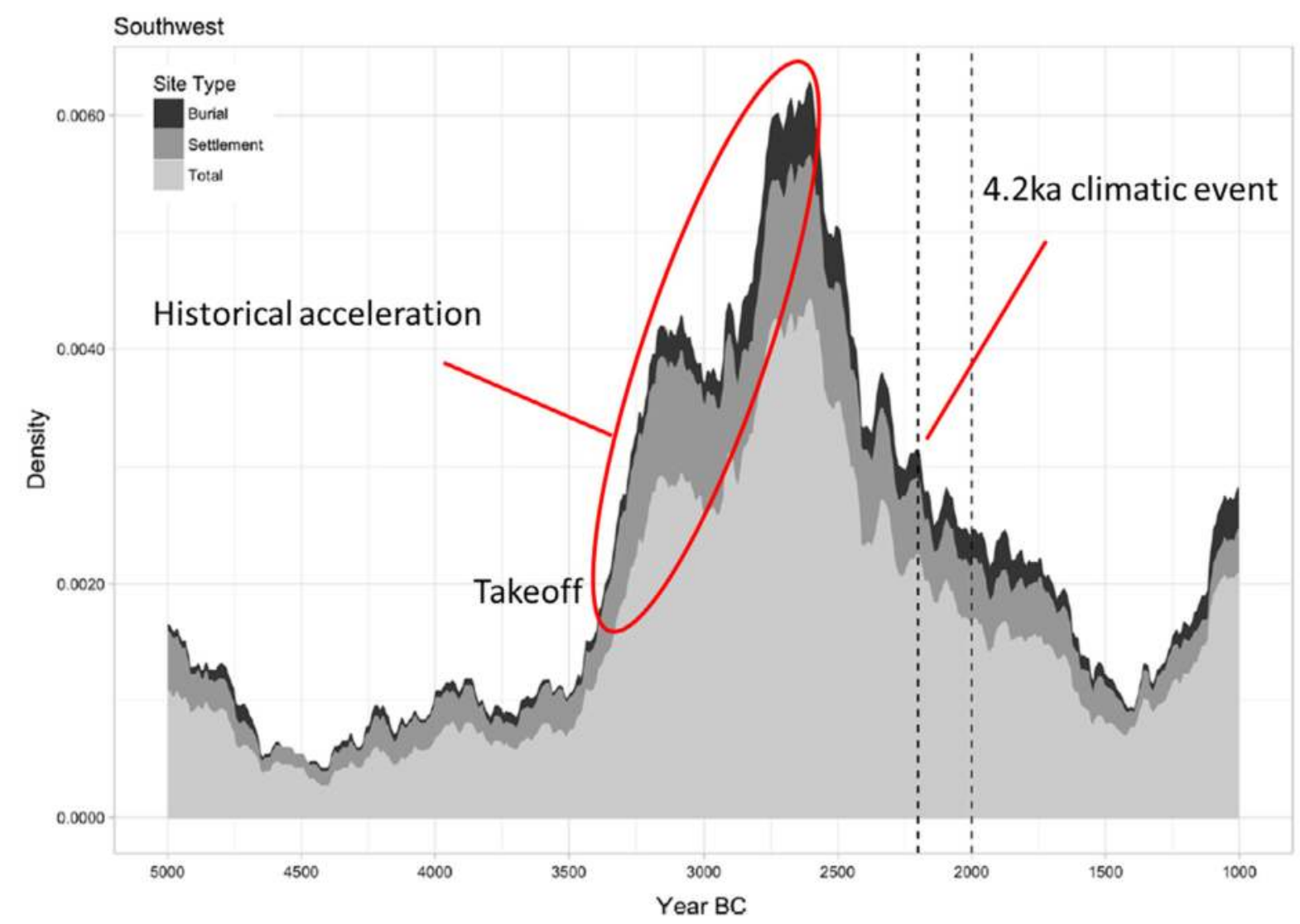

Figure 1 - summed calibrated date range distributions for burials and settlements in the Southwest Iberia (adapted after Blanco González et al. 2018, fig.18).

dynamics is still difficult to establish at the moment in this region.

Recently, a curve for the demographic development between 5000-1000 BC in southwest Iberia was published, using available radiocarbon dates for settlements and burials as proxy (Blanco-González et al. 2018). A tendency for accelerated growth starts around $3500 \mathrm{BP}$ and presents a first small break around 3000-2900 BC, and an even smaller one around 2800 BC (Figure 1). A peek of aridity was also detected at 2800 BC in the lower Guadiana basin (Fletcher et al. 2007). These early 3rd-millennium events correspond to the transition from the Late Neolithic to the Chalcolithic in the region. In the Perdigões sequence (the best dated for the south of Portugal), this moment corresponds to a slight reduction in the area of the enclosures. But this break in the curve is rapidly surpassed, and the accelerated demographic growth continued until the middle of the $3 \mathrm{rd}$ millennium $\mathrm{BC}$. It is then, previously to the climatic $4.2 \mathrm{ka}$ BP event, that the graph shows the beginning of a decline which extends to the middle of the 2nd millennium BC.

It is possible that this early chronology for the inversion of the tendency of growth, preceding a final abrupt breakdown by the end of the millennium, may still reflect the poor quality of the data (in terms of number of dated sites and of dates per site). A significant number of dates from the second half of the 3rd millennium BC recently obtained are not yet considered and recent data for Perdigões or Porto Torrão enclosures show intense chalcolithic activity during the third quarter of the 3rd millennium $B C$, suggesting that the breakdown was, in fact, in the beginning of the last quarter of the millennium. Even so, it does not seem to be related to the $4.2 \mathrm{ka}$ BP event in terms of cause/effect. That is suggested by the recent paleoclimatic data indicating that the $4.2 \mathrm{ka}$ BP event was not directly affecting the southwest (Schirrmacher et al. 2020: 12). In fact, this climatic occurrence is of large scale, and, as with all large-scale phenomena, it must have had diversified regional impacts according to local environmental and social conditions. In southwestern Iberia it seems to have been less effective and, at most, might have had an acceleration consequence for a change already in course. However, in certain areas, the impact of this event could have been particularly high, as recent studies in the Doñana and south Meseta seem to suggest (López-Sáez et al. 2017; 2018).

Another exogenous variable has been recently discussed: a migratory influx. DNA approaches have shown the flow into Iberia of Steppe-related ancestry 

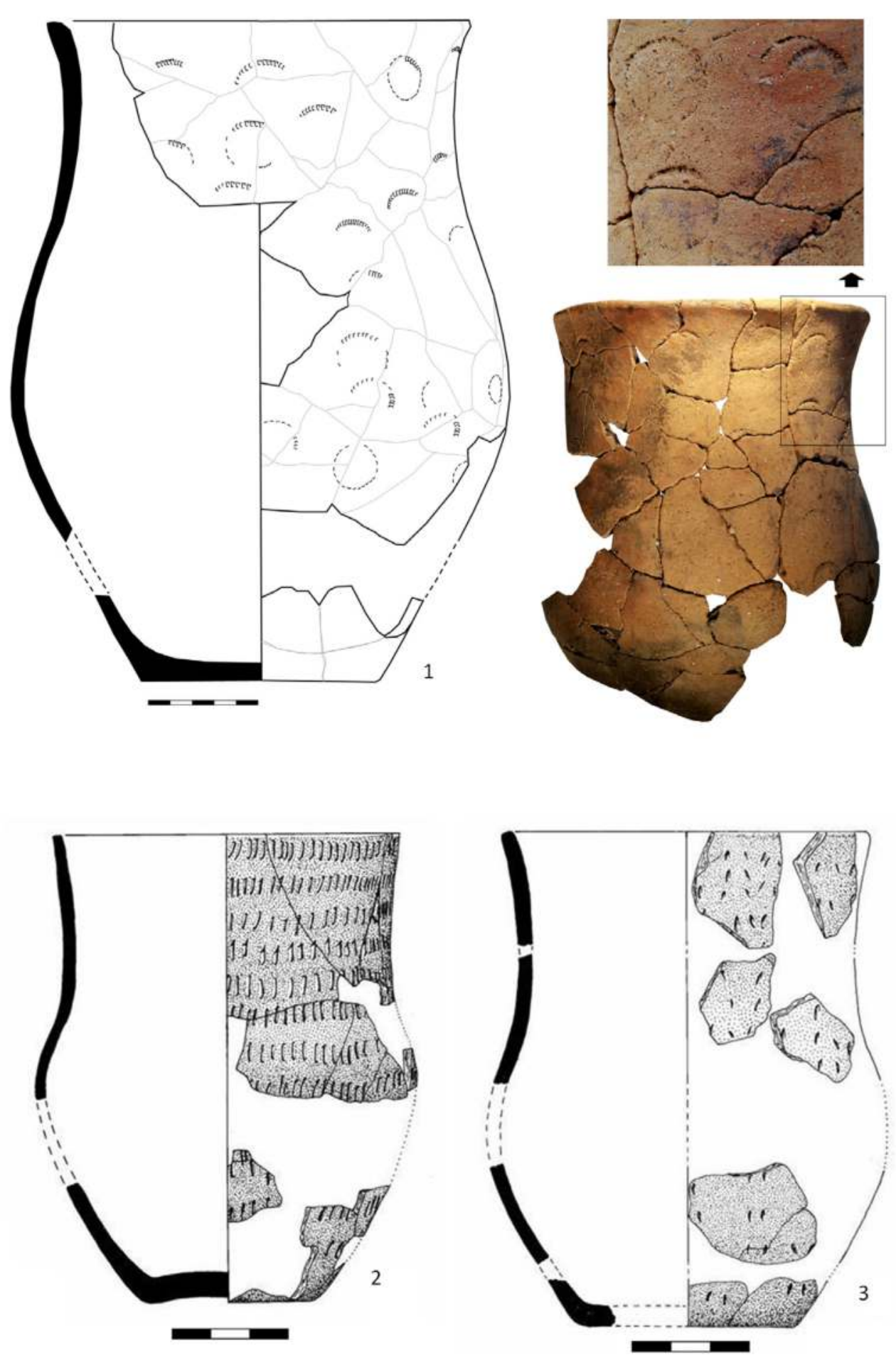

Figure 2 - Bell Beaker vessels with elongated profiles from the late $3^{\text {rd }}$ millennium BC. 1. Perdigões (South Portugal); 2. and 3. Fraga da Pena (Central-North Portugal).

during the Chalcolithic (Olalde et al. 2018). But the turnover detected in the Y-chromosome in the Bronze Age analysed individuals, with the almost complete substitution of the Chalcolithic lineages, suggests a significant contribution of migrations (Olalde et al. 2019). It is too soon, however, to evaluate the dimension and impact of these influxes in the social change observed by the end of the 3rd millennium BC. This information needs to be carefully integrated with archaeological and anthropological data and theory to try to understand the role of population influxes in the process. For the moment, and for southern Portugal, 
we can only say that the material assemblages of the Early Bronze Age do not show a significant number of items that can clearly be related to continental Europe within a context of an eventual massive and sudden population movement. However, some punctual elements of material culture can be stylistically related to continental influences. That is the case of a bell beaker from the Perdigões enclosure, dated from the end of the 3rd millennium $\mathrm{BC}$, that presents a high profile and is decorated with rows of circular denticulated stamps (Figure 2:1). Similar high profiles are also known in the walled enclosure of Fraga da Pena (central Portugal), also dated from the last century of the 3rd millennium $\mathrm{BC}$ (Figure 2: 2). But these are just scattered elements within a scenario characterised mainly by local and regional traditions.

Another hypothesis involving the movement of people was suggested to explain the demographic decay observed in the southwest. As this decay is roughly coincident with an opposite tendency observed in the southeast quadrant of Iberia, a possible west to east displacement of people was suggested (Lillios et al. 2016; Blanco González et al. 2018), although the existing isotopic studies amongst some Argaric populations (Aranda Jiménez et al. 2015) have not yet identified these possible migrants. Nevertheless, if an eventual migration could help to explain a demographic reduction in the southwest, it provides no explanation for the observed structural change in many other dimensions of the social system.

\subsection{Inside social relations}

Social dynamics are systemic and dialectical. Every circumstance in the development of a system may result in more or less profound changes or even collapse. The outcome, however, is forged in the interactions between the different elements within the system and in their external relations. In other words, the outcomes are neither inherent, linear, nor predictable. They are related to the contingencies of those interactions and to the relations they design. That is why they are not generalised, allowing diversified solutions and trajectories in time and space.

In the south of Portugal, as in the whole Andalusia (Gilman 2013; García Sanjuán 2017), and other regions, such as the Portuguese Estremadura (Jorge 1999; Sousa 2010) or central Iberia (Diáz-del Río 2003; Ríos 2011; Schmitt 2017), the accelerated social trajectory developed since the end of the 4 th millennium BC brought the region to levels of complexity previously unknown and with no parallel in central-north Portugal. The reasons for that asymmetry are not yet fully understood. We may think in terms of processes of resistance to social change, able to generate slower rhythms of transformation and induce distinctive trajectories. Studies of social resistance to change, however, are rare in Portuguese archaeology. Successful social conservatism tends to be interpreted not as such, but as minor expressions of trajectories of social complexification, adopting and adapting templates developed for other scenarios.

Nevertheless, southern Portugal was one of those areas that suffered an accelerated and intense transformation. The first two centuries of the second half of the 4th millennium BC marked the take-off of that trajectory (Valera 2018), after which there is an acceleration of the historical process of social complexification that will characterise the region in continuity between 3300$2300 / 2200$ BC. Amongst the multiplicity of variables of the systemic social relations developed during this period, four were selected to be discussed here.

First, the velocity of change that was rapidly brought about (metaphorically associated to an express train of the 'West' in the title of this chapter). Second, the participation in growing interaction networks of transregional scale, with significant circulation of people and exotic materials. Third, the development of a strong need for forms of ideological expression progressively more monumental and diversified, and consumers of high quantities of labour and logistics. Finally, the development of practices of social emulation and practices of wealth squandering, with the double and contradictory social role of promoting social inequality at the same time as they function to control it.

\section{The internal variables selected for discussion}

Eventually, the second metaphorical dimension of this chapter's title is now clearer: a nod to Agatha Christie's famous detective novel Death on the Orient Express. Those who know the book, or saw one of its cinematograph versions, will be aware that there is not just one individual responsible, but several. In fact, looking for a unique and specific cause for the abrupt decline of Chalcolithic societies in the southwest does not seem to be a very consistent purpose. Therefore, without seeking exclusivity, the four considered variables are all believed to be of importance to the outcome of the process, namely through the dynamics forged in the interactions between them.

\subsection{Historical acceleration}

For the analysis of historical processes, the relevant time is the social one, where the rhythms of human life are established (Elias 1998). These rhythms are submitted to accelerations framed by the theories of accelerated change (Kurzweil 2001) and of the pressure of the constant change (Koselleck 2001). The acceleration of historical processes is not just an increase of the velocity 


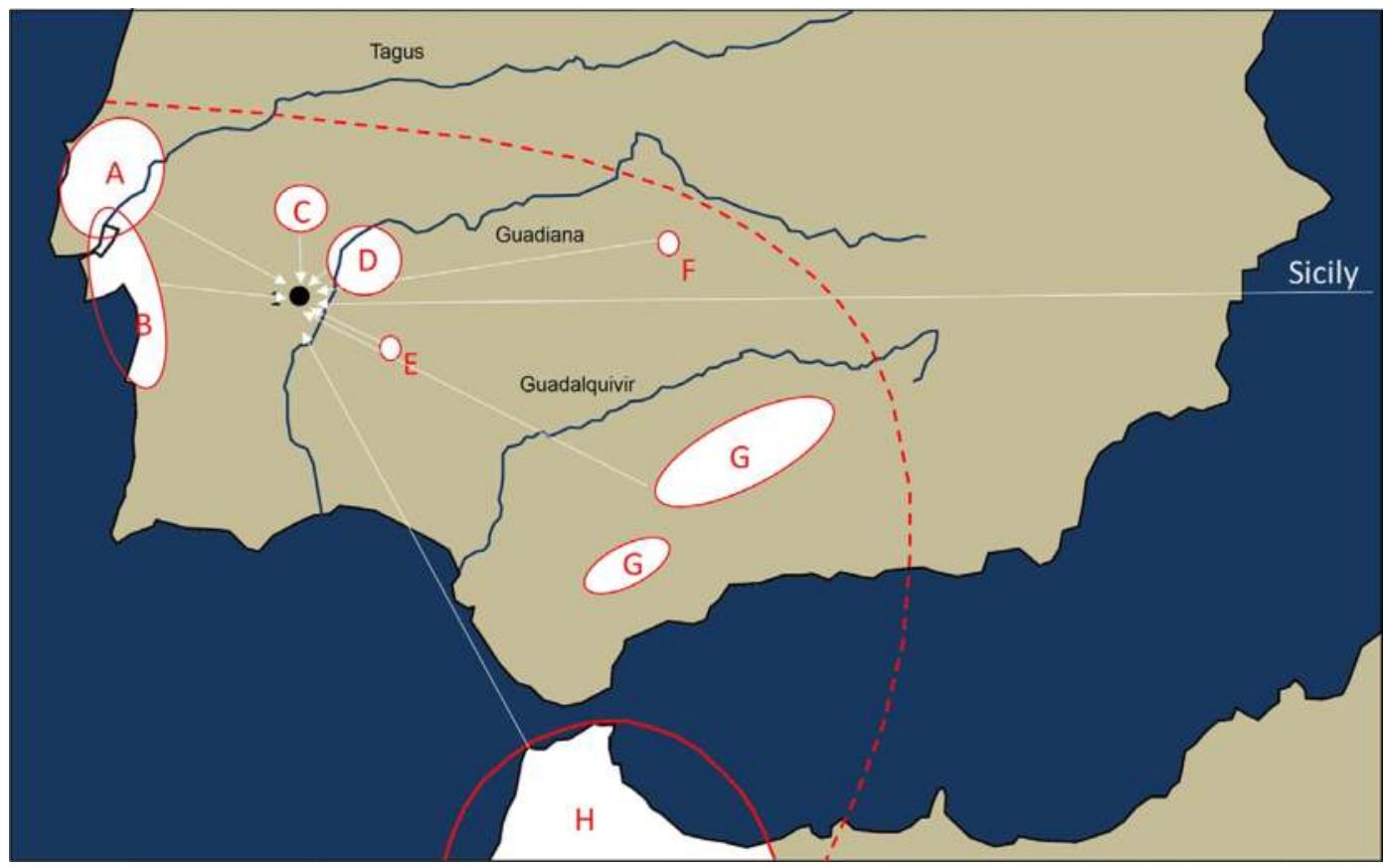

Figure 3 - Origin of raw materials of objects recorded at Perdigões enclosure that give the idea of the size of the interaction network where the site was integrated. A. Pottery styles and limestone; B. Sea and estuarine shells; C. Marble; D. Pottery styles; E. Variscite; F. Cinnabar; G. Oolithic flint; H. Ivory and amber from Sicily (after Valera 2017).

of a social trajectory, but also implicates qualitative changes correlative to that velocity. The increase of the speed of change may cause disparities and imbalances, and frequently the processes of adjustment result in an escape forward, increasing the speed and the problems it causes. Just like the person who runs faster to stand up, until the inevitable fall. Thus, the acceleration of historical processes, although not being an independent variable, emerging as it does from the dynamics generated in systemic interactions, has a strong influence on the outcome of those processes, becoming also an important heuristic instrument and gaining explicative significance.

If the acceleration observed in the late 4th, and especially during the $3 \mathrm{rd}$ millennium $\mathrm{BC}$ cannot be compared with accelerations that occurred in historical periods, and even less with the more recent times (modern and contemporary eras), it represented, nevertheless, a significant process with systemic impact. It was probably not fast enough to introduce noteworthy changes in personal experiences of time; and even less to transform cyclical perceptions of time in linear ones (as occurred in more recent centuries - Brook 2012; Koselleck 2001). But it was enough to increase and multiply the systemic effect of other variables and certainly to enlarge world visions and knowledge through increasing interactions and circulation of people. This acceleration can be seen in how rapidly the southwest communities became engaged in these interaction networks, how their investments in monumental forms of expression rapidly grew, or even in the signs of a rapid demographic expansion. The argument is that the velocity of those social developments act back as a pressure on the social system, namely in its productive and technological bases, driving it to levels of instability. It is not just the pressures caused by more people and more resources for investments in monumentality, it is also the velocity of the actual growing process itself.

\subsection{Large scale interaction}

Large-scale interaction is one of the factors that contributed to this acceleration of the historical process. The Late Neolithic societies of southwest Iberia, as others, entered rapidly in interaction networks progressively of larger scale. This process was itself an accelerator of social dynamics, for interchange generates transformation and implicates the increase of the rhythms of change.

In the Alentejo region we observe an introduction of exogenous materials (ivory, oolithic flint, cinnabar, seashells, variscite, and probably salt) in contexts dated from the second half of the 4th millennium BC. During the 3rd millennium BC the circulation of these exogenous materials would rapidly increase and new prestige items (made of amber, limestone, hyaline quartz, gold, jet, or prestige (bell beakers) or symbolic 
pottery) were added to the net, progressively more dense, connected and complex (Figure 3).

The search for and consumption of exogenous and exotic products were responding to growing necessities and simultaneously generated new ones. This represented a growing systemic dependence of those interaction networks and a progressive vulnerability to their vicissitudes, to their pressures and risks. Economies and social organisations linked through these networks were more vulnerable to problems that may arise in other areas, forcing the reconfiguration of relations, of trade routes, or political alliances. For instance, that is what seems to have happened with the circulation of salt: when the production sites of the Atlantic coast cease their intensive production is when the central Iberian ones start to become archaeologically visible, suggesting that a change in the network had a negative impact in de development of salt exploitation along the littoral, and a positive one in the hinterland (Valera 2017a). But because resources tend not to circulate alone, but in 'complexes of resources' (Bartelheim and Bueno Ramírez 2017; Valera 2020a), the positive and negative impacts in different regional systems would be even greater, for a change in one resource could impact the circulation of others.

The insertion of a local or regional settlement network in these large-scale interactions would be in part responsible for the development of social complexity in that area (as was recently proposed for Reguengos de Monsaraz (Valera 2018)), but would also generate dependence, becoming progressively more exposed to problems in other knots of the net. Problems that could be amplified by the tight relations between large-scale exchange and other systemic variables. By the middle of the 3rd millennium BC those networks that responded more to social, ideological, and political demands than to subsistence ones reached their peak, and were directly associated to other two developments: the investment in monumentality and social competition.

\subsection{Investments in monumental forms of expression}

The increasing investment in monumentality (for the discussion about the scope of the concept used here, see Valera 2019 and 2020b) and other exuberant forms of ideological display is also another structural aspect of the path followed by southwestern communities since the second half of the 4 th and during the $3 \mathrm{rd}$ millennium BC. Architectonically, monumental ditched enclosures emerged during the second half of the 4th millennium $\mathrm{BC}$, and some (Perdigões, Porto Torrão) rapidly acquire large dimensions. Simultaneously, funerary megalithic monuments reach their apogee in terms of investment, and necropolises of hypogea, sometimes associated with other monumental structures (e.g. a timber circle at Outeiro Alto 2 and stelae in Sobreira de Cima (Valera and Filipe 2012; Valera 2013a)), start to be built. Throughout the 3rd millennium BC the number of ditched enclosures grew, and some become large and complex, integrating monumental structures and no less monumental investments of communal work. Their designs, in several cases, are impregnated with ideological principles (Valera 2013b), and reunite evidence of intensive ceremonial practices, namely involving funerary practices and manipulation of human remains and the construction of tombs and other ceremonial monuments. Walled enclosures also appear, and, independently of the discussion about their functionality and intentions behind construction, they represent a significant investment in monumentality, something that also occurs in tholoi tombs, and even in the construction of huts (Valera et al. 2019).

Perdigões is a paradigmatic example of this increasing architectonic monumentality. Starting in the beginning of the second half of the 4th millennium BC as a small ditched enclosure, close to a megalithic cromlech, the site rapidly reached an enclosed area of $c .16$ ha, with several concentric enclosures, some of them with ditches already of considerable dimensions (Valera 2018). During the $3 \mathrm{rd}$ millennium $B C$ larger ditches were opened ( $3 \mathrm{~m}$ deep and 5-9 $\mathrm{m}$ wide) and intentionally filled (sometimes with re-cuttings). Several tombs were built (Valera et al. 2014) and, in the centre, there was a sequence of constructions involving a monumental timber circle, an hemi-ellipsoidal timber structure, a funerary area for secondary deposition of human cremated and unburned remains, a compound of stone structures, and a large and monumental circular stone cairn (this already dating from the end of the 3rd millennium BC), showing an intense and prolongated use of this central area for ceremonial purposes (Figure 4).

But the investment in monumentality goes behind architecture and landscape organisation and extends to the mobile material culture and to practices. As was recently argued, "monumentality is the "imaginal" category that evokes the images of the past and perpetuates their meanings through monuments that appear as forms of external memory. However, understanding monumentality as a symbolic imaginative creation that allows abstractions such as memories, absent in the material world, to gain material form has implications in the concept, turning it more inclusive, and especially allows us to consider that monumentality is also expressed by mobile materials and by practices.' (Valera 2020b). In fact, the abundant and diversified iconographic materials common to the southern half of Iberia during the $3 \mathrm{rd}$ millennium $\mathrm{BC}$, most of them made of exotic, exogenous materials and circulating through the large-scale interaction 


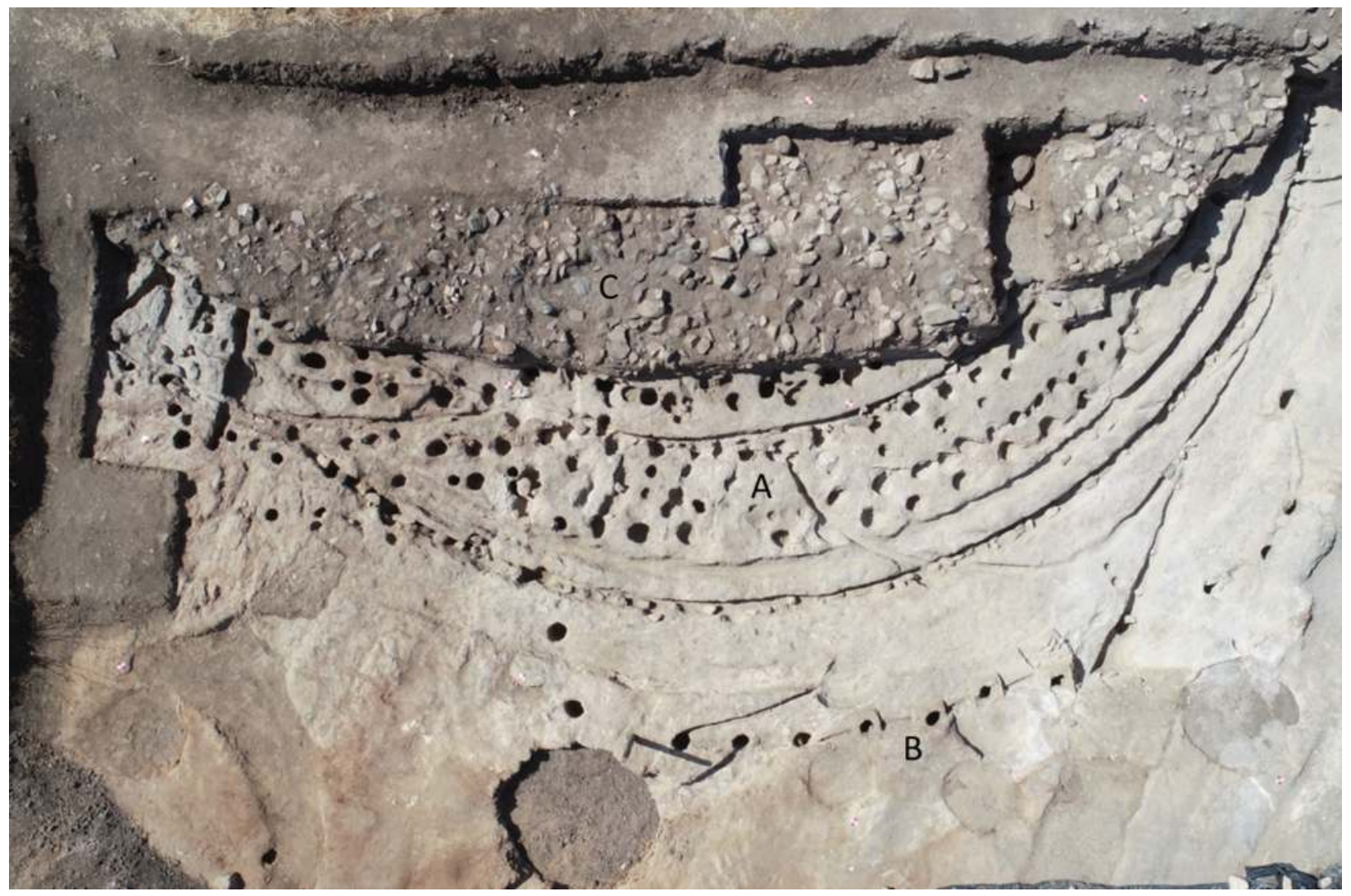

Figure 4 - Sequence of architectonic construction in the central area of Perdigões enclosures. Among others: A. Monumental enclosure delimited by a double ditch (the outside one with wedges inside) and internal rows of large post holes and palisades; B. Posterior hemi-ellipsoidal structures of large post holes; C. Large stone terrace that closes the sequence already in the Early Bronze Age (end of the 3rd millennium BC).

networks, can be perceived as monumental forms of ideological display. This occurs not just because of the immaterial dimension of monumentality, but also because of the material support of these objects, which is ostentatious in nature due to its origin and investments likely to be obtained. During the 3rd millennium BC we observe the emergence of what might be called a 'monumental material culture', one representing, in its production, circulation and consumption, a significant social investment.

However, these monumental forms of expression, by constituting a variable that has a significant pressure over the productive subsystem and over social interaction, might generate systemic imbalances when elevated to certain levels, namely in terms of the capacity of production to sustain the investments, or in the ability of leadership to congregate the required labour and control over production and circulation. This systemic risk is higher when large investments in monumentality are associated with strategies and practices of social emulation.

\subsection{Strategies of social emulation}

Growing evidence suggesting practices of social competition, generating procedures of squander, are also being detected in the archaeological record of south Portugal during the 3rd millennium BC.

Examples come from the enclosures of Salvada and Monte das Cabeceiras 2, already discussed in Valera 2019. These are two large and complex ditched enclosures, generically contemporary, located just 3.5 $\mathrm{km}$ apart. If we take into consideration that models should have a predictive utility, this situation should not be expected. In fact, if we adopt the traditional models on hierarchic settlements developed for Chalcolithic southwest Iberia, usually based on size and complexity of sites (with territories dominated by big centres surrounded by peripheral smaller sites), then we should not expect to find two large ditched enclosures (slightly bigger than Perdigões) so close to each other, as occurs for these two contexts (Figure 5). Material culture from both sites indicates that they were contemporaneous during the $3 \mathrm{rd}$ millennium 


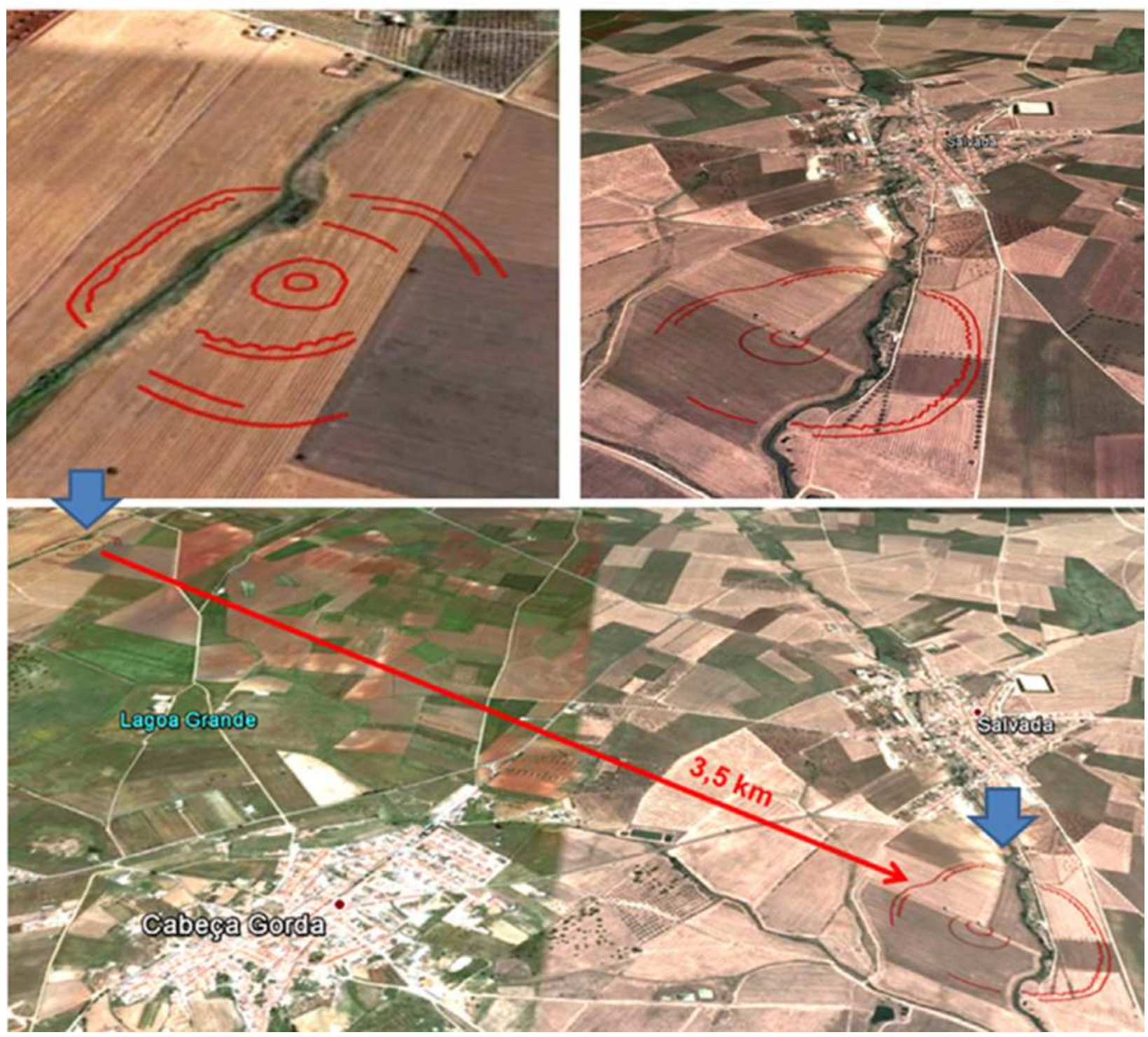

Figure 5 - Proximity of the two large ditched enclosures of Monte das Cabeceiras 2 (left) and Salvada (right), both in Beja district, South Portugal.

$\mathrm{BC}$, although no absolute chronology is yet available for one of them. But if they were not, then we would have the hard task of explaining why a 'macro-site' would disappear and another, with the same general design, size and material culture, would appear just $3.5 \mathrm{~km}$ away. In fact, the development of two large and similar ditched enclosures in such proximity could be better understood in the context of social competition through mimetic behaviours between neighbouring communities and leaderships, developing efforts to attract and congregate supporters.

Social competition drives communities towards monumentality, to excessive constructions, to inflate the symbolic dimension of architectures and of behaviours. This process is already present in the constructive phases, as the ability to attract followers/ participants for the building work is simultaneously a competitive process and a factor of consolidation of factions. It generates disproportionality between the investment/achievement and the real socio-economic bases of the communities (sometimes putting it at risk or driving it to collapse). Size would be a makeup, and it could be misleading regarding the real level of social complexity of those communities, and especially in terms of the capacities of their economic basis. The recent overview of the available empirical data regarding direct and indirect indicators of agriculture in the hinterland of southern Portugal during the Late Neolithic (Valera 2018) shows a marked low quantity, far from suggesting an intensive agricultural system, well implanted, and frequently inferred from the investments in the monumental constructions of the period. In fact, these increasing investments in monumental forms of ideological display (architectonic, mobile material culture, practices) drive 
societies to a necessity of intensification of production as a response to ideological demands. This generates an inflated pressure on the productive and technological subsystems, which might not be able to support such pressure in the long term.

Another example of mechanisms of noninstitutionalised social competition was recently discussed for the funerary contexts of Perdigões (Valera et al. 2015; Valera 2019). The collective use and reuse with secondary depositions of two tholoi-type tombs in the eastern part of the enclosure (Tombs 1 and 2) was partially contemporary with the secondary deposition of human cremated remains in pit graves located in the centre of the enclosure (in the area where the central timber circle previously was). They present different architectonic solutions, different treatments of the bodies of hundreds of individuals, and both sets of contexts present rich but quite different funerary assemblages (namely in exogenous exotic materials), where no individual status can be identified in the collectiveness of each tomb. This situation suggests processes of group differentiation and competition through squander practices of exogenous exotic materials. These strategies of social emulation implicate a strong economic, social and political effort to integrate the large-scale interaction networks, through which the exotic items were obtained, used and squandered. Again, pressure is placed on the productive and exchange subsystems. The same might be said in terms of the thousands of animal remains that are being recovered in several ditched enclosures, indicating massive killing and consumption of animals at ceremonial events.

Adding to that, these strategies of wealth squandering, if operating within a framework of social competition and identity differentiation, also generate a contradictory effect. If they promote inequality through ostentation and enrolment of supporters, they also help to resist and control it through a 'waste' of wealth, taken from the world of the living, preventing accumulation processes that could sustain the growing inequality. Both situations, however, constitute strategies of risk in terms of the orientation of the productive effort, constrained by an accelerated increasing of ostentation and investments in ideological display.

\section{Concluding}

Following a previous analysis (Valera 2015), this contribution argues that the transition between the Chalcolithic and the Bronze Age in south Portugal (and southwest Iberia in general), occurred during the last centuries of the 3rd millennium BC, is a periodisation milestone (in the sense of Aróstegui 1995), corresponding to a social breakdown. To that statement, it adds the claim that explanations for this historical circumstance cannot be found in a unique major cause, but within the interactions between several variables, internal and external to the social system.

While external factors, such as environmental changes or the influx of new populations, are considered variables still presenting us with blurred information for this region (although the more recent comparative studies indicate relevant and promising data for the issue), four endogenous aspects were identified to highlight and discuss their explanatory potential regarding the outcome of the historical process in question (without the prejudice of the relevance of other variables not considered here).

As argued before (Thomas 1991; Whittle 1996; Bradley 1998; Valera 2018), the bases of the Neolithic world rested largely in an ideological revolution and in a new form of organising cosmologic views, developing a need with no precedents for a strong symbolic display that led to a 'monumentalization of life' (Valera 2020b). This process was not linear and does not present the same outlines in the different Iberian regions we may considerer. In areas where it reached more complex levels, such as the Iberian southwest, it might have induced systemic imbalances, with unsustainable pressures in the long term over the productive system and over polities still based in transegalitarian social relations (Hayden 1995; Gilman 2013), encouraging strategies of social resistance and fission. In fact, we have no clear evidence for the recognition of the 'cage theory' (Diáz-del-Rio 2004; Gilman 2013) that could traduce more hierarchised social relations. Perdigões is again paradigmatic here. In the second half of the 3rd millennium BC, where in many areas of continental Europe and Iberia individuality is emerging in funerary contexts as expression of growing inequalities, in all the funerary contexts so far excavated in the enclosure, the situation is that of a complete rejection of individualisation. There are almost exclusively secondary depositions forming comingled accumulation of bones, where no sense of the individual is perpetuated. If differences are displayed, they are between groups with bones agglomerated in different tombs, and not through wealth, but through style and practices (Valera et al. 2015; Valera 2017b), documenting processes of identity management and symbolically reaffirming collectivism over emerging individualism.

The development of social relations of emulation and cosmological views impose strong and demanding monumental devices of communication, that simultaneously sustain and depend on large interaction networks of exotic materials and require huge investments in labour out of the subsistence 
activities. These dynamics show a strong acceleration during the 3rd millennium BC. This inflation of monumentality and associated labour, linked to a greater dependence of interaction networks, would have engendered imbalances in the productive sphere, still unprepared to sustain that trajectory in the long term and to cope with higher regional vulnerability to network events (openness to effects of crisis emerging in other regions integrating the net). At a point, this turns the system more susceptible to external factors. The level of engagement of Chalcolithic societies of south Portugal with the 'monumentalization of life' engendered systemic vulnerabilities that could be aggravated in periods of crisis. External variables, such as the environmental one, could then appear as accelerating factors. Even if the region seems not have been affected by a significant impact of the 4.2 ka event according to recent paleoclimatic data (Schirrmacher et al. 2020), smaller variations could be relevant to a more vulnerable social system.

As noted, a first peek of aridity was overpassed in the early 3rd millennium $B C$, showing that the system was still able to respond and continue to follow the same general path. By the beginning of the third quarter of the millennium, when the levels of interaction, social competition and investments in monumental display had reach their apogee in the region, signs of instability and retraction start to be detected. This suggests that, if the subsequent breakdown was roughly coincident with the 4.2 ka climatic event, problems were already occurring, and that, if climatic factors are to be considered in the outcome, they essentially catalysed tendencies of disaggregation of the current social order already in course.

By the end of the 3rd millennium $\mathrm{BC}$, a breakdown of a path social complexification occurred in the south of Portugal (and southwestern Iberia in general), while that same general trajectory proceed in the Iberian southeast, at least until the middle of the 2nd millennium BC (Lull et al. 2013; Aranda Jiménez et al. 2017). What immediately followed that breakdown in the transition/early 2nd millennium $\mathrm{BC}$ in the southern Portugal is still blurred. That path, however, would be resumed by the second quarter/middle of the 2nd millennium BC, but in new terms, when profound changes had already occurred, namely in funerary practices and in the general ideological sphere, where the needs for collective monumental forms of display and large-scale interaction seem less prominent.

\section{Acknowledgments}

The author wishes to thank the organisers of this forum for their kind invitation to present this study, and to the institutions that made the development of research into these subjects possible: Era Arqueologia S.A., ICArEHB-UAlg, and Fundação para a Ciência e Tecnologia, currently through the project PTDC/EPHARQ/0798/2014).

\section{References}

Aranda Jiménez, G., Montón-Subías, S. and SánchezRomero, R. 2015. The archaeology of Bronze Age Iberia: Argaric societies. New York: Routledge.

Aranda Jiménez, G., Lozano Medina, A., Díaz-Zorita Bonilla, M., Sanchez Romero, M. and Escudero Carrillo, J. 2017. Cuntural continuity and social resistance; the chronology of megalithic funerary practices in Southern Iberia. European Journal of Archaeology 1-15, doi:10.1017/eaa2017.42.

Aróstegui, J. 1995. La investigación histórica: teoría y método. Barcelona: Crítica.

Bartelheim, M. and Bueno Ramírez, P. 2017. Resource Use and Sociocultural Dynamics in the Chalcolithic of the Iberian Peninsula. An Introduction and Synthesis, in M. Bartelhein, P. Bueno Ramírez and M. Kunst (eds) Key resources and socio-cultural developments in the Iberian Chalcolithic: 7-21. Tübingen: Library Publishing.

Blanco-González, B., Lillios, K., López-Sáez, J.A., Drake, B.L. 2018. Cultural, Demographic and Environmental Dynamics of the Copper and Early Bronze Age in Iberia (3300-1500 BC): Towards an Interregional Multiproxy Comparison at the Time of the $4.2 \mathrm{ky}$ BP Event. Journal of World Prehistory, doi.org/10.1007/ s10963-018-9113-3.

Bradley, R. 1998. The significance of Monuments. London: Routledge.

Brook, T. 2012. O chapéu de Vermeer: O século XVII e o começo do mundo globalizado. Rio de Janeiro: Record.

Cruz Berrocal, M., García Sanjuán, L. and Gilman, A. 2013. The Prehistory of Iberia. Debating Early Stratification and the State. London: Routledge.

Diáz-del Río, P. 2003. Recintos de fosos del III milenio ac en la meseta peninsular. Trabajos de Prehistoria 60(2): 61-78.

Díaz-del-Río, P. 2004. Factionalism and collective labor in Copper Age Iberia. Trabajos de

Prehistoria 61: 85-98.

Elias, N. 1998. Sobre o tempo. Rio de Janeiro: Jorge Zahar. Espino, D. 2004. La gestión del paisaje vegetal en la Prehistoria Reciente y Protohistoria en la Cuenca Media del Guadiana a partir de la Antracología. PhD tesis, Universidad de Extremadura.

Fletcher, W., Bosky, T. and Moura, D. 2007. Palynological evidence for environmental and climate, change in the Lower Guadiana valley (Portugal) during the last 13,000 years. The Holocene 17: 479-492.

Ganascia, J.-G. 2018. O mito da singularidade. Devemos temer a inteligência artificial? Lisboa: Círculo de Leitores. 
García Sanjuán, L. 2017. Farming economy and wealth economy in the Copper Age of the Lower Guadalquivir river. Debating strategic resources at Valencina de la Concepción (Seville, Spain). in M. Bartelhein, P. Bueno Ramírez and M. Kunst (eds) Key resources and socio-cultural developments in the Iberian Chalcolithic: 237-256. Tübingen: Library Publishing.

Gilman, A. 2013. Were there States during Later Prehistory of Southern Iberia?, in M. Cruz Berrocal, L. García Sanjuán and A. Gilman (eds) The Prehistory of Iberia. Debating early social stratification and the State: 10-28. London: Routledge.

Godinho, V.M. 1946. A crise da História e as suas directrizes. Lisboa. Empresa Contemporânea de Edições.

Godinho, V.M. 1955. A historiografia portuguesa: orientações, problemas, perspectivas. Revista de História 21/22: 3-21.

Godinho, V.M.1978. A evolução dos complexos históricogeográficos. Ensaios, vol. II: 19-28.

Hayden, B. 1995. Pathways to power: principles for creating socioeconomic inequalities, in T.D. Price and G.M. Feinman (eds) Foundations of Social Inequality: 15-86. New York: Springer Science.

Jorge, S.O. 1999. Domesticar a terra. Lisboa: Gradiva.

Koselleck, R. 2001. Los estratos del tiempo: estúdios sobre la historia. Barcelona: Ediciones Paidés.

Kurzweil, R. 2001. The Law of Accelerating Returns. Published on KurzweilAI.net March 7.

Lillios, K., Blanco-González, B., Drake, B.L. and López-Sàez, J.A. 2016. Mid-late Holocene climate, demography, and cultural dynamics in Iberia: A multi-proxy approach. Quaternary Science Reviews 135: 138-153.

López-Sáez, J.A., Blanco, A., Pérez-Díaz, S., Alba, Z.F., Luelmo, R., Glais, A. and Núñez, S. 2017. Landscapes, human activities and climate dynamics in the South Meseta of the Iberian Peninsula during the 3rd and 2nd millennia cal BC, in M. Bartelheim, P. Bueno and M. Kunst (eds) Key resources and social-cultural developments in the Iberian Chalcolithic: 129-142. Tübingen: Eberhard Karls Universtät Tübingen.

López-Sáez, J.A., Pérez-Díaz, S., Rodríguez, A., Blanco, A., Villarías, J.J.R., Luelmo, R., Jiménez, G., Celestino, S., Cerrillo, E., Pérez, J.N. and León, A. 2018. Mid-late Holocene environment and cultural dynamics at south-west tip of Europe (Doñana National Park, SW Iberia, Spain). Journal of Archaeological Science: Reports 22: 58-78.

Lull, V., Mico, R., Rihuete Herrada, C. and Risch, R., 2013. Political collapse and social change at the end of El Argar, in H. Meller, F. Bertemes, H.-R. Bork and R. Risch (eds) 1600 - Kultureller Umbruch im Schatten des Thera-Ausbruchs?: 283-302. 4. Mitteldeutscher Archäaologentag vom 14. bis 16. Oktober 2011 in Halle (Saale). Landesamt für Denkmalpflege und Archaeologie Sachsen-Anhalt. Halle:Landesmuseum für Vorgeschichte.
Magny, M., Combourieu-Nebout, N., de Beaulieu, J.L., Bout-Roumazeilles, V., Colombaroli, D. and Desprat, S. 2013. North-south palaeohydrological contrasts in the central Mediterranean during the Holocene. Climate of the Past 9: 2043-2071.

Magny, M., Vannière, B., Zanchetta, G., Fouache, E., Touchais, G., Petrika, L., Coussot, C., WalterSimonnet, A.V. and Arnaud, F. 2009. Possible complexity of the climatic event around 4300-3800 cal. BP in the central and western Mediterranean. The Holocene 19: 823-833.

Mateus, J.E., and Queiroz, P.F. 2000. Lakelets, lagoons and peat-mires in the coastal plane South of Lisbon - Palaeoecology of the Northern Littoral of Alentejo, in J.E. Mateus and P.F. Queiroz (eds) Rapid environmental change in the Mediterranean Region - The contribution of the high-resolution lacustrine records from the last 80 millennia: 33-37. Lisboa: IPA.

Meller, H., Risch, R., Jung, R. and Arz, H.W. (eds) 2015. 2200 $B C$-A climatic breakdown as a cause for the collapse of the old world? 7th Archaeological Conference of Central Germany. Halle: Tagungen des Landesmuseums für Vorgeschichte Halle 13 (1-2).

Olalde, I., Brace, S., Allentoft, M.E., Armit, I., Kristiansen, K., Rohland, N., Mallick, S., Booth, T., Szécsényi-nagy, A., Mittnik, A., Altena, E., Lipson, M., Lazaridis, I., Patterson, N., Broomandkhoshbacht, N., Diekmann, Y., Faltyskova, Z., Fernandes, D., Ferry, M., Harney, E., de Knijff, P., Michel, M., Oppenheimer, J., Stewardson, K., Barclay, A., Alt, K.W. Avilés, A., Bánkky, E., Bernabò-Brea, M.; Lilloin, D., Blasco, C., Bonsall, C., Bonsall, L., Allen, T., Büster, L., Carver, S., Navarro, L. C., Craig, O. E., Cook, G. T., Cunliffe, B., Denaire, A., Dinwiddy, K.E., Dodwell, N., Ernée, M., Evans, C., Kuchaík, M., Francès, J., Fokkens, H., Fowler, C., Gazenbeek, M., Garrido, R., Haber-Uriarte, M., Haduch, E., Hey, G., Jowett, N., Knowles, T., Massy, K., Pfrengle, S., Lefranc, P., Lemercier, O., Lefebvre, A., Lomba, J., Majó, T., Mckinley, J.I., Mcsweeney, K., Gusztáv, M. B., Modi, A., Kulcsár, G., Kiss, V., Czene, A., Patay, R., Endrdi, A., Köhler, K., Hajdu, T., Cardoso, J. L., Lieseau, C., Parker Pearson, M., Wlodarczak, P., Price, T.D., Prieto, P., Rey, P.-J., Ríos, P., Risch, R., Rojo, M. A., Schmitt, A., Serralongue, J., Silva, A. M., Smrčka, V., Vergnaud, L., Zilhão, J., Caramelli, D., Higham, T., Heyd, V., Sheridan, A., Sjögren, K.G., Thomas, M.G., Stockhammer, P. W., Pinhasi, R., Krause, J., Haak, W., Barnes, I., Lalueza-Fox, C. and Reich, D. 2018. The Beaker phenomenon and the genomic transformation of Northwest Europe. Nature 555: 190-196, doi:10.1038/nature25738.

Olalde, I., Mallick, S., Patterson, N., Rohland, N., Villalba-Mouco, V., Silva, M., Dulias, K., Edwards, C.J., Gandini, F., Pala, M., Soares, P., Ferrando-Bernal, M., Adamski, N., Broomandkhoshbacht, N., Cheronet, O., Culleton, B.J., Fernandes, D., Lawson, A.M., Mah, M., Oppenheimer, J., Stewardson, K., Zhang, Z., 
Jiménez Arenas, J.M., Toro Moyano, I.J., SalazarGarcía, D.C., Castanyer, P., Santos, M., Tremoleda, J., Lozano, M., García Borja, P., Fernández-Eraso, J., Mujika-Alustiza, J.A., Barroso, C., Bermúdez, F.J., Viguera Mínguez, E., Burch, J., Coromina, N., Vivó, D., Cebrià, A., Fullola, J.M., García-Puchol, O., Ignacio Morales, J., Oms, F.X., Majó, T., Vergès, J.M., DíazCarvaja, A., Ollich-Castanyer, I., López-Cachero, F.J., Silva, A.M., Alonso-Fernández, C., Delibes de Castro, G., Echevarría, J.J., Moreno-Márquez, A., Pascual Berlanga, G., Ramos-García, P., Ramos-Muñoz, J., Vijande Vila, E., Aguilella Arzo, G., Esparza Arroyo, A., Lillios, K.T., Mack, J., Velasco-Vázquez, J., Waterman, A., Lugo Enrich, L.B., Benito Sánchez, M., Agustí, B., Codina, F., de Prado, G., Estalrrich, A., Fernández Flores, A., Finlayson, C., Finlayson, G., Finlayson, S., Giles-Guzmán, F., Rosas, A., Barciela González, V., García Atiénzar, G., Hernández Pérez, M.S., Llanos, A., Carrión Marco, Y., Collado Beneyto, I., López-Serrano, D., Sanz Tormo, M., Valera, A.C., Blasco, C., Liesau, C., Ríos, P., Daura, J., Pedro Michó, M.J., Diez-Castillo, A.A., Flores Fernández, R., Francès Farré, J., Garrido-Pena, R., Gonçalves, V.G., GuerraDoce, E., Herrero-Corral, A.M., Juan-Cabanilles, J., López-Reyes, D., McClure, S.B., Merino Pérez, M., Oliver Foix, A., Sanz Borràs, M., Sousa, A.C., Vidal Encinas, J.M., Kennett, D.J., Richards, M.B., Alt, K.W., Haak, W., Pinhasi, R., Lalueza-Fox, C. and Reich, D. 2019. Science 363: 1230-1234.

Ríos, P. 2011. Territorio y sociedad en la región de madrid durante el iii milenio a. c. el referente del yacimiento de camino de las yeseras. Madrid: Universidad Autónoma de Madrid.

Schirrmacher, J., Kneisel, J., Knitter, D., Kamer, W., Hinz, M., Schneider, R.R., Weinelt, M. 2020. Spatial patterns of temperature, precipitation, and settlement dynamics on the Iberian Peninsula during the Chalcolithic and the Bronze Age. Quaternary Science Reviews 233. doi.org/10.1016/j. quascirev.2020.106220.

Schmitt, F. 2017. Enclose where the river flows. New investigations on the Southern Meseta and the ditched enclosures of Azután (Toledo), in M. Bartelheim, P. Bueno Ramírez and M. Kunst (eds) Key resources and socio-cultural developments in the Iberian Chalcolithic: 37-57. Ressourcen Kulturen 6. Tübingen: Library Publishing.

Sousa, A.C. 2010. OPenedo do Lexime a sequência do neolítico final e calcolítico da Península de Lisboa. Unpublished PhD thesis, Universidade de Lisboa.

Thomas, J. 1991. Rethinking the Neolithic. Cambridge; Cambridge University Press.

Valera, A.C. (ed.) 2013a. Sobreira de Cima. Necrópole de hipogeus do Neolítico (Vidigueira, Beja). ERA Monográfica 1. Lisboa: Nia-Era.

Valera, A.C. 2013b. Breve apontamento sobre a dimensão cosmogónica dos recintos de fossos da Pré-História
Recente no Interior Alentejano. Cadernos do Endovélico 1, Colibri/CMA: 51-63.

Valera, A.C. 2015. Social change in the late 3rd millennium BC in Portugal: The twilight of enclosures, in H. Meller, R. Risch, R. Jung and W. Arz (eds) 2200 BC - A climatic breakdown as a cause for the collapse of the old world?: 409-427. 7th Archaeological Conference of Central Germany. Halle: Tagungen des Landesmuseums für Vorgeschichte Halle 13 (12).

Valera, A.C. 2017a. Salt in the 4th and 3rd Millennia BC in Portugal: specialization, distribution, and consumption. Cuaternario y Geomorfología: 105-121.

Valera, A.C. 2017b. The 'Exogenous' at Perdigões. Approaching interaction in the late 4 th and $3 \mathrm{rd}$ millennium BC in Southwest Iberia, in M. Bartlheim, P. Bueno Ramírez and M. Kunst (eds) Key resources and sociocultural developments in the Iberian Chalcolithic: 201-224. Tübingen: Library Publishing.

Valera, A.C. (ed.) 2018. Os Perdigões Neolíticos. Génese e desenvolvimento (de meados do $4^{\circ}$ aos inícios do $3^{\circ}$ milénio ac). Perdigões Monográfica 1. Lisboa: NIA-ERA.

Valera, A.C. 2019. Landscapes of complexity in Southern Portugal during the 4 th and 3rd millennium BC, in J. Müller, M. Hintz and M. Wunderlich (eds) Megaliths, Societies, Landscapes. Early monumentality and social differentiation in Neolithic Europe: 1039-1054. Frühe Monumentalität und soziale Differenzierung 18. Vol. 3/3. Bonn: Verlag Dr. Rudolf Habelt GmbH.

Valera, A.C. 2020a. Interação e recursos exóticos na PréHistória Recente: a circulação e consumo de marfim em Portugal, in R. Vilaça and R.S. Aguiar (eds) Mobilidades na Pré-história. Pessoas, recursos, objetos, sítios e territórios: 135-181. Coimbra: Imprensa da Universidade de Coimbra.

Valera, A.C. 2020b. Ephemeral and Cosmological Monumentality: the 'strange' ditched enclosures of Chalcolithic South Portugal, in A.B. Gebaue, L. Sorensen, A. Teather and A.C. Valera (eds) Monumentalizing life in the Neolithic: Narratives of continuity and change. Oxford: Oxbow Books: 237-250.

Valera, A.C. and Filipe, V. 2012. A necrópole de hipogeus do Neolítico Final do Outeiro Alto 2 (Brinches, Serpa). Apontamentos de Arqueologia e Património 8: 29-42.

Valera, A.C, Mataloto, R. and Basílio, A.C. 2019. The South Portugal perspective. Beaker sites or sites with beakers?, in Alex M. Gibson (ed.) Bell Beaker Settlement of Europe. The Bell Beaker phenomenon from a domestic perspective: 1-23. Prehistoric Society Research Paper 9. Oxford: Oxbow Books.

Valera, A.C., Schuhmacher, T.X. and Banerjee, A. 2015. Ivory in the Chalcolithic enclosure of Perdigões (South Portugal): the social role of an exotic raw material. World Archaeology 47(3): 390-413.

Valera, A.C., Silva, A.M., Cunha, C. and Evangelista, L.S. 2014. Funerary practices and body manipulations 
at Neolithic and Chalcolithic Perdigões ditched enclosures (South Portugal), in: A.C. Valera (ed.) Recent Prehistoric Enclosures and Funerary Practices: 37-57. British Archaeological Reports International Series 2676. Oxford: Archaeopress.

Weinelt, M., Schwab, C., Kneisel, J. and Hinz, M. 2015. Climate and societal change in the western Mediterranean area around $4.2 \mathrm{ka} B \mathrm{~B}$, in H. Meller, R. Risch, R. Jung and H.W. Arz (eds) 2200 BC - A climatic breakdown as a cause for the collapse of the old world?: 461-480. 7th Archaeological Conference of Central Germany. Halle: Tagungen des Landesmuseums für Vorgeschichte Halle 13 (1-2).

Weiner, M.H. 2014. The interaction of climate change and agency in the collapse of civilizations ca. 23002000 BC. Tree-Ring Research 70(3): 1-16.

Whittle, A. 1996. Europe in the Neolithic: The Creation of new worlds. Cambridge: Cambridge University Press. 


\title{
Chapter 7
}

\section{A Slow Awakening on the Plain: The Bronze Age in the Beja Region (South Portugal)}

\author{
Miguel Serra \\ Department of Culture and Heritage, Serpa City Council \\ CEAACP - University of Coimbra \\ mserra@cm-serpa.pt
}

\begin{abstract}
The Bronze Age in the region of Beja was traditionally known only for the funerary spaces scattered across the vast plain, clustered in small cist necropolises with individual burials. It was on this essentially funerary empirical basis that Hermanfrid Schubart individualised the so-called 'Southwest Bronze Age Culture', separating it from the other peninsular entities (Schubart 1975). 'The Necropolis may have been the burial centre of a larger-spread settlement that only came together here for the funeral and the construction of the tomb', so summarised Schubart (1965: 86) as the main features of these communities, which were assumed to be essentially itinerant, wandering through a vast territory where resources were exploited, serving the necropolis as a privileged space for congregation and social emulation. The numerous archaeological works carried out in the last 15 years in this region would change and enrich this perspective, revealing a more complex and diversified funerary world, with tombs excavated in the rock, and for the first time ever registering the settlements of these communities, consisting of open lowland settlements with numerous pits, but without clear evidence of other constructions. The knowledge of these new realities allowed for a deeper look at the enormous changes that characterise the entry into the 2nd millennium BC. In the Late Bronze Age (LBA), we will again see the appearance of monumental architectures, focused on inhabited spaces, which shape the few hills in this flat landscape, revealing settlements surrounded by imposing walls and a settlement strategy that occupies all kinds of areas in this territory (Serra and Porfírio 2017: 225; Soares 2013: 275).
\end{abstract}

Key words: Iberian Southwest Bronze Age (SBA), architectures, monumentality, settlement.

\section{Introduction}

The trajectory of the communities of lower Alentejo during the Bronze Age has become a theme that needs to be extensively revised in view of the large number of archaeological research contributions in the last 15 years which have allowed for criticism of models that have been partly succeeded since the 1970s. The profound changes between both extremes of the 2nd millennium $B C$ are not yet fully understood, as well as the separation between the different moments of change during the Bronze Age.

The increasing social complexity experienced from the Late Neolithic to the end of the Chalcolithic period, ends abruptly with the turning from the 3rd to the 2nd millennium $\mathrm{BC}$ and gives rise to a more discreet society with new forms of social organisation and occupation of the landscape, but which also reveal new forms of complexity increasingly centred on the individual and the creation of an hierarchical society that will reach its fullness at the end of the Bronze Age.

The scenario that we had until recently to characterise the Early and Middle Bronze Ages, was based almost exclusively on funerary data, given the lack of information on the settlements of these communities, which led to the creation of interpretative models based on a very incomplete framework. Thus a general interpretation developed that focused on Early/Middle Bronze Age itinerant societies who only left clear evidence from funerary spaces which appear to us in a somewhat linear and simplistic way in their evolution towards greater complexity, in view of the progressive appearance of outstanding individuals within these communities; and it was these personalities who lead them on a path of intensification of hierarchy until the end of the millennium, when finally there is evidence of large collective constructions, such as fortified settlements, which shows the reaching of a new phase of great social complexity.

The large amount a new data available allows new ways of interpretation that evidence the rich diversity and complexity of this period, instead of a linear evolutionary path. The transformations experienced by the Bronze Age communities of the Beja Plain between the beginning of the 2nd and the beginning of the 1st millennium $\mathrm{BC}$, and their main characteristics and foundations, are the main objectives that we intend to achieve via this brief essay.

From the beginning to the end of the 2nd millennium $\mathrm{BC}$ in the Alentejo Plains

The Alentejo region (south Portugal), more precisely an extensive range of $c .70-75 \mathrm{~km}$, with a west-east orientation, and $30 \mathrm{~km}$ wide, covering in general terms 


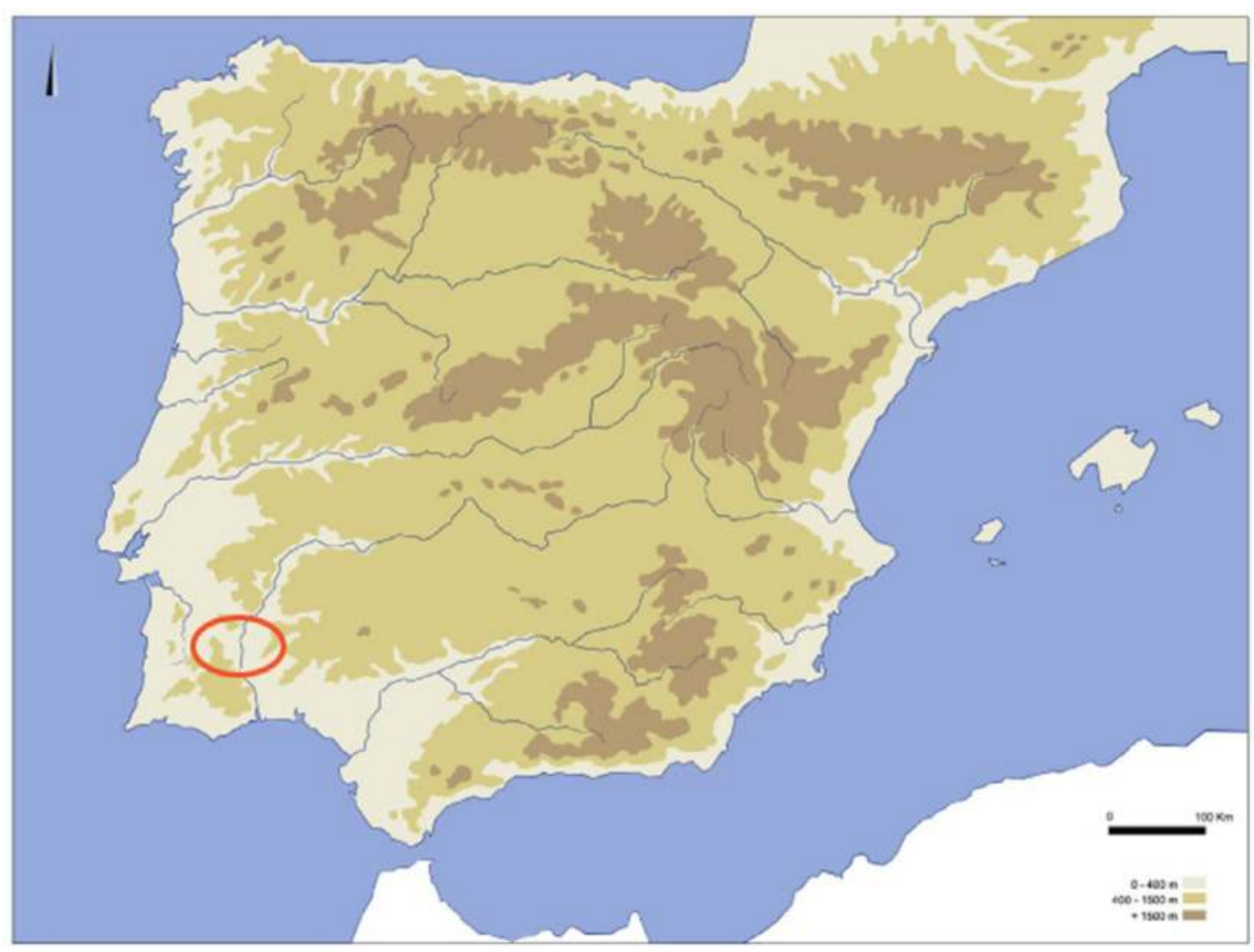

Figure 1. Location of the Beja region within the Iberian Peninsula (Miguel Serra).

the current municipalities of Ferreira do Alentejo, Beja and Serpa, presents a large number of ditched enclosures, with marked differences between them (Valera and Pereiro 2015: 321), which were constructed during the Late Neolithic until the Late Chalcolithic (Figures 1 and 2).

These sites show great diversity in size, from small enclosures, e.g. Bela Vista 5 (Beja), with only 0.003 ha, to the 17.4 ha of Salvada 1 (Beja), or even the 8.2 ha of Monte das Cabeceiras 2 (Beja) (Valera 2013: 102); there is also the largest ditched enclosure known on Portuguese territory - Porto Torrão (Ferreira do Alentejo), with its impressive 100 ha (Valera 2018: 10). But the variability in ditched enclosures is also marked, in terms of topography, design, chronology, and duration or architectural features (Valera and Pereiro 2015: 322).

This phenomenon is part of the growing social complexity that the Neolithic communities have been tracing since the second half of the 4th millennium $\mathrm{BC}$, witnessing demographic growth, agro-pastoral intensification, architectural monumentality, and the development of new technologies and increased longdistance exchange networks (Valera 2015a: 409), these advances reaching their peak at the end of the 3rd millennium BC (Valera 2014: 301).
With the entry into the 2nd millennium BC, new ditched enclosures are no longer being built, clearly demonstrating that this is an essentially Neolithic and Chalcolithic phenomenon (Valera 2013: 102). One can even speak of a social collapse occurring at the end of the 3rd millennium BC, one that, in southwestern Iberia, leads to the disappearance of the forms of social organisation and construction/monumentalisation of the landscape, asserted in this region since the Late Neolithic and across the entire Chalcolithic (Valera 2014: 301).

These structural changes in the cosmological and ideological dimensions of society are also reflected in the material culture, witnessing abrupt changes in the lithics industry, pottery manufacture, and especially in the production of objects related to ideology and the sacred world. These symbolic objects assumed a major role during the Neolithic and Chalcolithic, reaching very high levels of exuberance during the $3 \mathrm{rd}$ millennium $\mathrm{BC}$, but evidencing an abrupt decay at the end of the millennium, and practically disappearing with the beginning of the 2nd millennium BC. On the other hand, we encounter during the entry into the 2nd millennium $B C$ the emergence of exceptional goods, like weapons, more related to specific individuals who begin to emerge in this new social paradigm (Valera 2015: 418). 


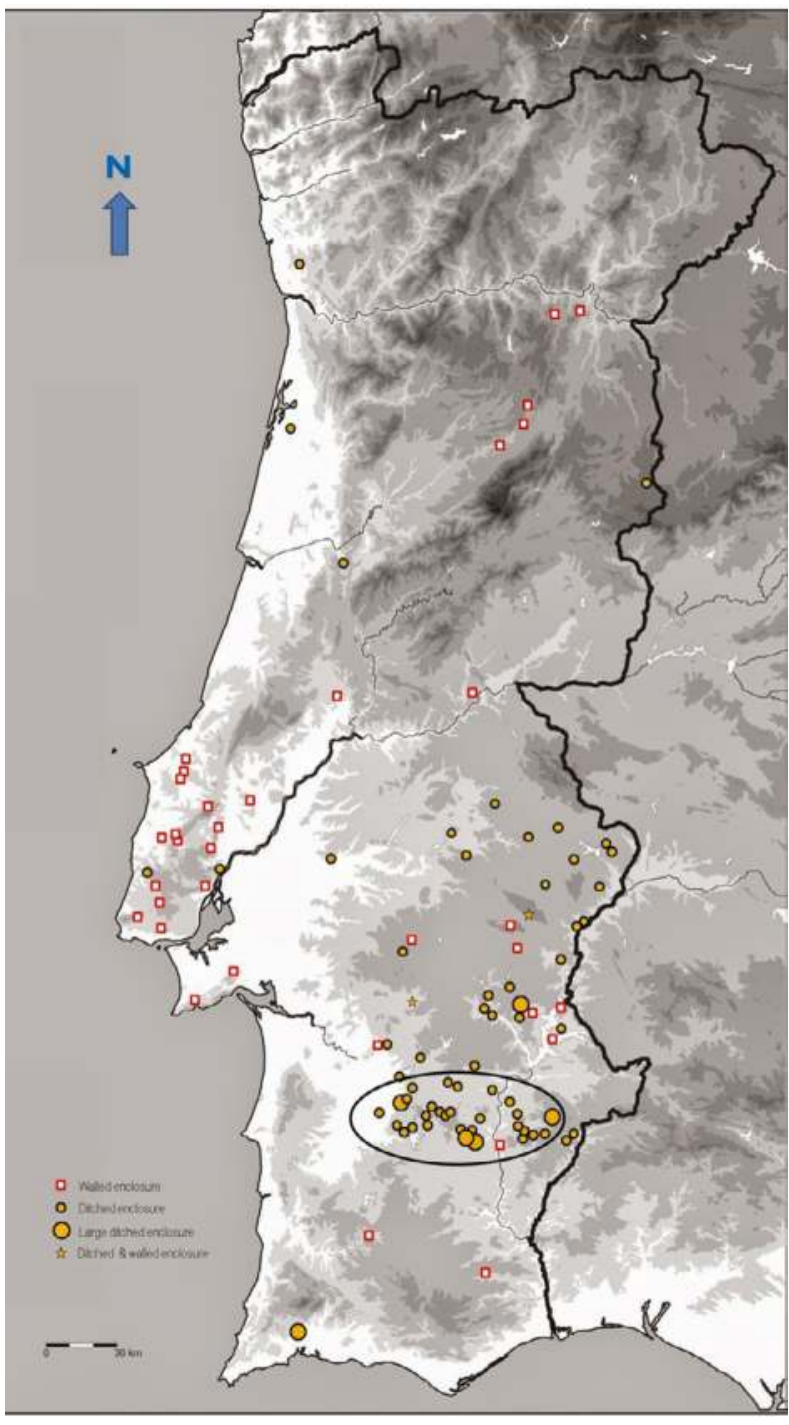

Figure 2. Prehistoric ditched enclosures within the Beja region (after Valera 2015b).

The role of the individual clearly shows with the disappearance of the collective funerary practices, with all their diversity, that are replaced by individual burials and their more homogeneous votive materials, reflecting a new world pointing towards social individualisation. The abrupt end of the Chalcolithic communities in this region could be explained by the internal tensions already ongoing, motivated by social competition and its resistance, exacerbated by growth in the demographic that could have become unsustainable, but whose causes are not yet totally known (Valera 2015: 422).

The monumental expressiveness at the end of the 3rd millennium $\mathrm{BC}$, materialised in the large ditched enclosures and the collective funerary architecture, is followed by a period of fragmentation of the settlement forms scattered throughout the Low Alentejo plains throughout the Bronze Age, assuming much more discrete architectural features compared to the previous paradigm (Serra and Porfírio 2018: 37); one might even speak of an absence of architecture (Valera 2014: 303).

Throughout much of the 2nd millennium BC, the forms of human occupation across the vast Beja Plain will be marked by the presence of spaces devoid of monumental constructions, at both domestic and funeral sites. The new settlements are mainly located on rich agricultural soils, occupying gentle slopes or low hills, in the vicinity of small streams draining the vast flat terrain; these settlements are presented with no defensive or delimiting structures, and are essentially composed of 'negative architectures', expressed in hundreds of simple pits excavated in the bedrock (Antunes et al. 2012: 278).

The funerary world of the 2nd millennium $\mathrm{BC}$ also undergoes a huge transformation, both in terms of practices and architecture. The constructive complexity is significantly reduced, despite the great polymorphism, and we find cist necropolises, which can also demonstrate great constructive variety, and sometimes a faint monumental expression, co-existing with underground graves, practically unknown in this territory until a decade and a half ago, such as hypogea and simple pits, which in both cases show a clear tendency towards practices of individual burial, contrasting with the large collective burials of the preceding period (Serra and Porfírio 2018: 37-40).

However, these communities, apparently egalitarian in terms of settlement strategies, show evidence of growing hierarchy, with the appearance of notable individuals, as materialised in weapon production, distinctive individual burials, and the exhibition of their power represented, for instance, on the Alentejo slabs - with the figuration of their 'symbols of power', e.g. swords, halberds, axes, and that unknown motif, the 'anchor-shaped object'.

These outstanding individuals surely assumed controlling roles within their communities, creating rivalry and competition between them, which could have let to the need to search for more secure locations on higher ground, and the unity of several communities around a common goal - the construction of wellprotected settlements.

It will only be at the end of the 2nd millennium $\mathrm{BC}$, and the transition to the 1st millennium $\mathrm{BC}$, during the LBA, that we will again see a monumentalising of the landscape, now materialised in very different ways from those observed in the 3rd millennium BC. The construction of imposing defensive walls, sometimes 
surrounded by ditches, becomes a characteristic image of the architectural expression of LBA communities, showing the emergence of the large fortified settlements that clearly mark the new forms of social organisation of this period in the southwest of the Iberian Peninsula (Serra and Porfírio 2017: 225; Soares 2013: 275).

\section{From 'Iberian Southwestern Bronze Age Culture' to the empirical revolution of 'Alqueva Project'}

The first findings of the Bronze Age in the region of Beja date to the late 19th century and soon attracted the attention of several researchers to the importance of the region. These early findings were mainly made of metallic materials, some cist graves and decorated stelae, often considered as tombstones (Serra and Porfírio 2018: 33). The discoveries follow one another throughout the 1930s and 1960s, with the important works of Abel Viana and Fernando Nunes Ribeiro, especially with the identification and excavation of several cist necropolises, that motivated the latter author to make one of the first attempts to systematise the regional Bronze Age, separating it from the sphere of influence of the 'El Argar Culture' of what is now south-eastern Spain, as many other researchers did at the time (Ribeiro 1965; Serra and Porfírio 2012: 137, 138) (Figure 3).

But it was not until the 1970s that the framework of the so-called 'Southwest Bronze Age' (SBA) was defined, through the extensive systematisation undertaken by Hermanfrid Schubart (1975), following his own work on the vast and monumental cist necropolis of Atalaia (Ourique), whose excavation had been started in fact by Abel Viana (Schubart 1965). The German author rigorously compiled the available information from the literature and the Bronze Age collections from museums in the Alentejo, Algarve (Portugal) and western Andaluzia (Spain), defining the 'Iberian Southwestern Bronze Age Culture' - based on data mainly from funerary occurrences (Parreira 2014: 16; Schubart 1971a).

Such researches would come to define the regional systematisation that allowed the characterisation of the Late Chalcolithic, the evolutionary framework of the Bronze Age in the southwest of the Iberian Peninsula, and the accentuated transformations of the Late Bronze Age, a period only vaguely understood by Schubart due to the lack of data. The chronological framework of the SBA was also traced, based exclusively on funerary findings and the simple absence/presence criteria of associations between metallic and ceramic artifacts from these funerary contexts (Parreira 2014: 16).

Thus, a stage of initial 'formation' was defined, in parallel with the late Bell Beaker Culture, referred to

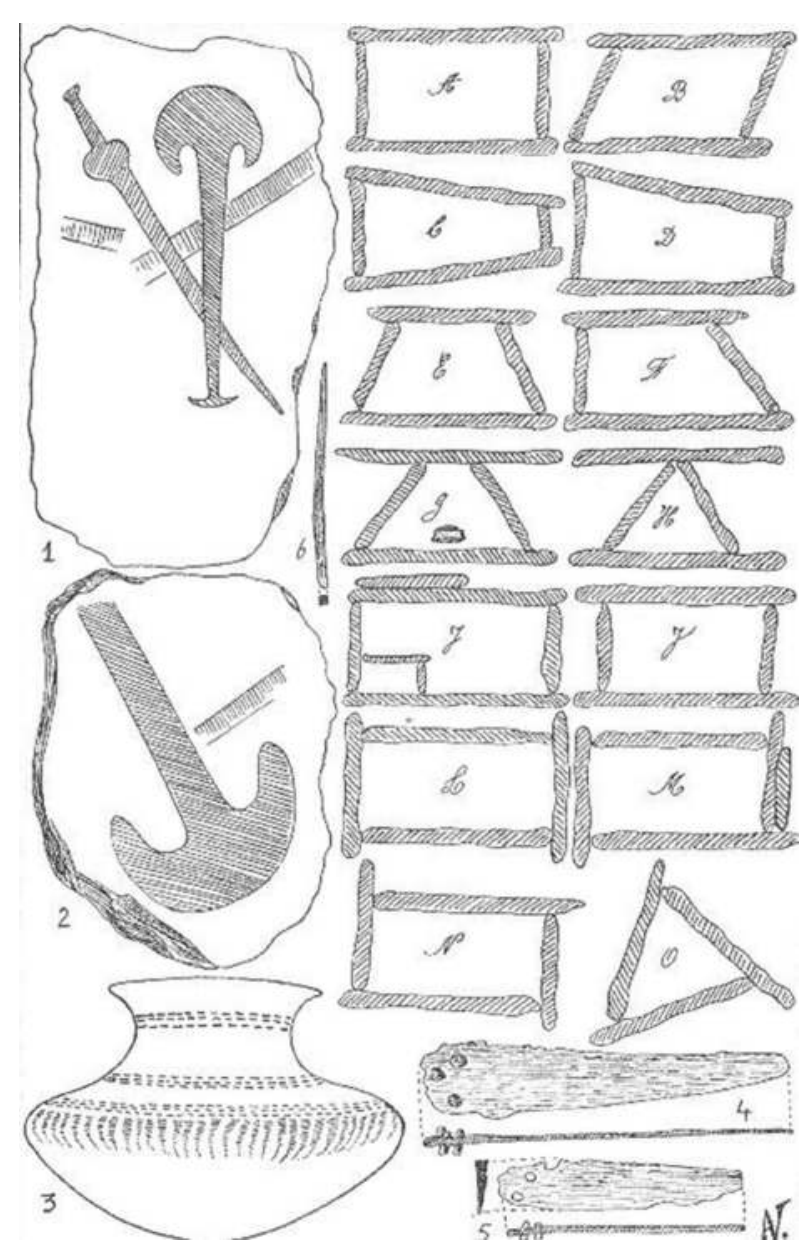

Figure 3: Cists, stelae and other Bronze Age findings from the Beja region (after Viana 1956: 164, fig. 75).

as the 'Ferradeira Horizon' (Schubart 1971b), a stage, however, that never achieved general recognition (Mataloto et al. 2013: 303), followed by a division into SBA I and II, to which other authors would add a final phase, SBA III, a designation that failed to receive acceptance and that would correspond to the LBA (Parreira 1995: 132).

This quadripartite chronological scheme would be more or less maintained by several researchers, with minor changes in the designation of their subdivisions and chronological limits, until the recent proposal by Rui Mataloto, José Matos Martins and António Monge Soares (2013), one based on a vast array of radiometric data, presenting several changes in Schubart's scheme, and one which we shall follow in this present contribution.

The new periodisation proposal includes the 'Ferradeira Horizon' in the Late Chalcolithic, a cultural horizon defined by Schubart mainly by the presence of individual burials, whether in cists or not (1971b), and clearly constituted by historical-cultural content 
Table 1. Traditional 'Southwestern Bronze Age' (SBA) periodisation (after Mataloto et al. 2013: 307).

\begin{tabular}{|c|c|c|c|}
\hline H. Schubart & R. Parreira & $\begin{array}{l}\text { J. Soares and C. T. } \\
\text { Silva }\end{array}$ & M. V. Gomes \\
\hline $\begin{array}{l}\text { 'Ferradeira Horizon' } \\
1800-1500 \mathrm{BC}\end{array}$ & $\begin{array}{l}\text { 'Ferradeira Horizon' } \\
\text { 2200-2000 BC }\end{array}$ & \begin{tabular}{|l} 
Early SBA \\
$2200 / 2100-1900 / 1800 \mathrm{BC}$
\end{tabular} & $\begin{array}{l}\text { 'Ferradeira Horizon' } \\
\text { 2000-1800 BC }\end{array}$ \\
\hline $\begin{array}{l}\text { SBA I } \\
1500-1100 \mathrm{BC}\end{array}$ & $\begin{array}{l}\text { SBA I } \\
2000-1700 \text { BC }\end{array}$ & $\begin{array}{l}\text { MBA I } \\
1900 / 1800-1600 / 1500 \mathrm{BC}\end{array}$ & $\begin{array}{l}\text { SBA I } \\
1800-1500 \mathrm{BC} \\
\end{array}$ \\
\hline \multirow[t]{2}{*}{$\begin{array}{l}\text { SBA II } \\
1100-700 \mathrm{BC}\end{array}$} & \begin{tabular}{|l} 
SBA II \\
$1700-1200 \mathrm{BC}$ \\
\end{tabular} & $\begin{array}{l}\text { MBA II } \\
1600 / 1500-1200 \mathrm{BC}\end{array}$ & $\begin{array}{l}\text { SBA II } \\
1500-1200 \mathrm{BC} \\
\end{array}$ \\
\hline & \begin{tabular}{|l} 
SBA III \\
$1200-700 \mathrm{BC}$
\end{tabular} & $\begin{array}{l}\text { LBA } \\
1200 / 1100-700 \mathrm{BC}\end{array}$ & $\begin{array}{l}\text { LBA } \\
1200 / 1100-800 \mathrm{BC}\end{array}$ \\
\hline
\end{tabular}

Table 2. 'Southwestern Bronze Age' (SBA) periodisation according to Mataloto et al. 2013: 330.

\begin{tabular}{|l|l|}
\hline $\begin{array}{l}\text { Late Chalcolithic (including 'Ferradeira Horizon') } \\
2650-2560 / 2070-1930 \mathrm{BC}\end{array}$ & $\begin{array}{l}\text { Bell Beaker Culture } \\
2650-2440 / 1950-1810 \mathrm{BC}\end{array}$ \\
\hline SBA & \\
$2070-1930 / 1170-1050 \mathrm{BC}$ & \\
\hline $\begin{array}{l}\text { Late SBA } \\
1170-1050 / 780-730 \mathrm{BC}\end{array}$ & \\
\hline
\end{tabular}

based exclusively in the funerary record. This was the basis intended to explain the presence of some assemblages with absences of Bell Beaker pottery and the non-existence of fortified settlements that would be associated with superior cultural groups (Mataloto et al. 2013: 304). This cultural concept, experiencing some adaptation, was progressively accepted as having an initial moment within the Bronze Age (Parreira 1995; Soares and Silva 1995), contemporary with the Bell Beaker realities. The research of the last decades has revealed that the fortified Bell Beaker settlements, unknown in Schubart's time, leave no margin for the existence of a culturally significant moment that fits the characteristics proposed for the 'Ferradeira Horizon' (Mataloto et al. 2013: 305).

Thus, the 'Ferradeira Horizon' was included in the Late Chalcolithic, assuming that it has a clear transition moment to the Bronze Age, when we focus on the abandonment of fortified settlements, ditched enclosures (Mataloto et al. 2013: 322; Valera 2013; Valera 2014; Valera 2015a), and the transformation of the funerary architecture (with the appearance of individual burials in a range of different types - pits, cists, or the reuse of megalithic monuments).

The transition to the SBA is placed, in this new proposal, from 2070-1930 BC, and the beginning of the Late SBA from 1170-1050 BC, with its end between 780730 BC (Mataloto et al. 2013: 330), eliminating the classic division into four sub-periods, and defining only two major moments within the Bronze Age: the 'Full Bronze Age' (corresponding to what was generally termed the Early/Ancient Bronze and Middle Bronze Age, lasting between 760 and 1020 years), and the LBA, with its shorter duration, between 440 and 270 years.

Schubart's absence of very well-defined differences to justify the transition within the two major moments of the SBA, and the later acquisition of radiocarbon data, have led to several reviews and many different proposals for this moment (Table 1). With the emergence of innumerable new data in the past two decades, which have revealed the appearance of many new Bronze Age settlements and new funerary architectures, we can accept that the major transformations within the Bronze Age only appear in the transition to its last moment, giving support to the elimination of former subdivisions within the SBA (Table 2).

To conclude this brief chapter, we need to explain a little bit about the reasons behind the changes in the periodisation described above and the way we came to look at Bronze Age communities.

If, during the 20th century, the Bronze Age of the southwest Iberian Peninsula was defined mainly by funerary spaces, with the resulting interpretations in terms of social organisation and models of settlement, the beginning of the 21st century has come up with a series of novelties that have changed the current paradigm. In fact, the look at the communities of the 2nd millennium $\mathrm{BC}$ was based on the emphasis given to the role played in the construction of funerary spaces, the only examples to exhibit any community effort in terms of the organisation needed for constructive development, to the detriment of housing spaces, which for a long time remained hidden from 
researchers, and it was considered that their absence in the archaeological record was due to the fact that these were, to a degree, roaming communities, with little need therefore to invest in housing construction (Parreira 1998: 269; Serra and Porfírio 2018: 39).

It is only with the great innovations accelerated by preventive archaeology, resulting from the minimisation archaeological works of the Alqueva Dam Project (and others to a lesser extent) that this interpretative paradigm has changed, and, above all, is energised by new expressions of modes of human occupation within the territory, which have finally revealed to us the places of the living, while bringing to light a vaster polymorphism present in funerary architectures.

\section{Of large, ditched enclosures and pit settlements}

With the entry into the 2 nd millennium BC, the markedly lowland territories, situated on the axis between the present municipalities of Ferreira do Alentejo, Beja and Serpa (the central plain area in the Lower Alentejo region), not only fail to witness the construction of new large enclosures and large collective tombs, but the Chalcolithic architectural complexity is also extinguished, witnessing the appearance of more modest settlements and necropolises.

The SBA communities look for hospitable mountain regions located near the main natural resources that guarantee their livelihoods, i.e. the rich agricultural soils of the 'Barros Pretos de Beja' (Beja's black clay soils) and the small watercourses that irrigate the plain, either the Sado (west), or Guadiana Basins (east) - the two main rivers of southern Portugal.

Settlement on these easily accessible flat areas, slopes and hills is very modest, concentrating constructive efforts on the opening of numerous pits/silos in the region's soft bedrock, with virtually no stone or permanent constructions, nor defensive or delimiting construction viz-à-viz the inhabited spaces (Antunes et al. 2012; Serra and Porfírio 2017).

The pits, which can form settlements for hundreds, and occupying large areas, as in Torre Velha 3, with its c. 200 pits attributable to the SBA, spread over 10 ha (Alves et al. 2010) (Figure 4), reveal a wide variety of secondary uses: with household materials, filled with sediments scarce in archaeological materials, reused as graves, or used as working areas (e.g. knapping) (Pereiro et al. 2012), etc., whereas their primary use is often unknown to us (Figure 5). However, it should be noted that in some settlements pits were found containing carbonised seeds, referring to their use as storage pits, as in the open settlement of Pedreira de Trigaches 2 (Beja), where one of the pits contained thousands of barley seeds (Antunes et al. 2012: 285) (Figure 6).

The archaeological works of the last 15 years have contributed to the recognition of numerous pit settlements in the territory under review; however this does not necessarily mean that we are in the presence of large permanent/sedentary communities.

Given the lack of investment in durable constructions, such as stone structures, we can suggest the

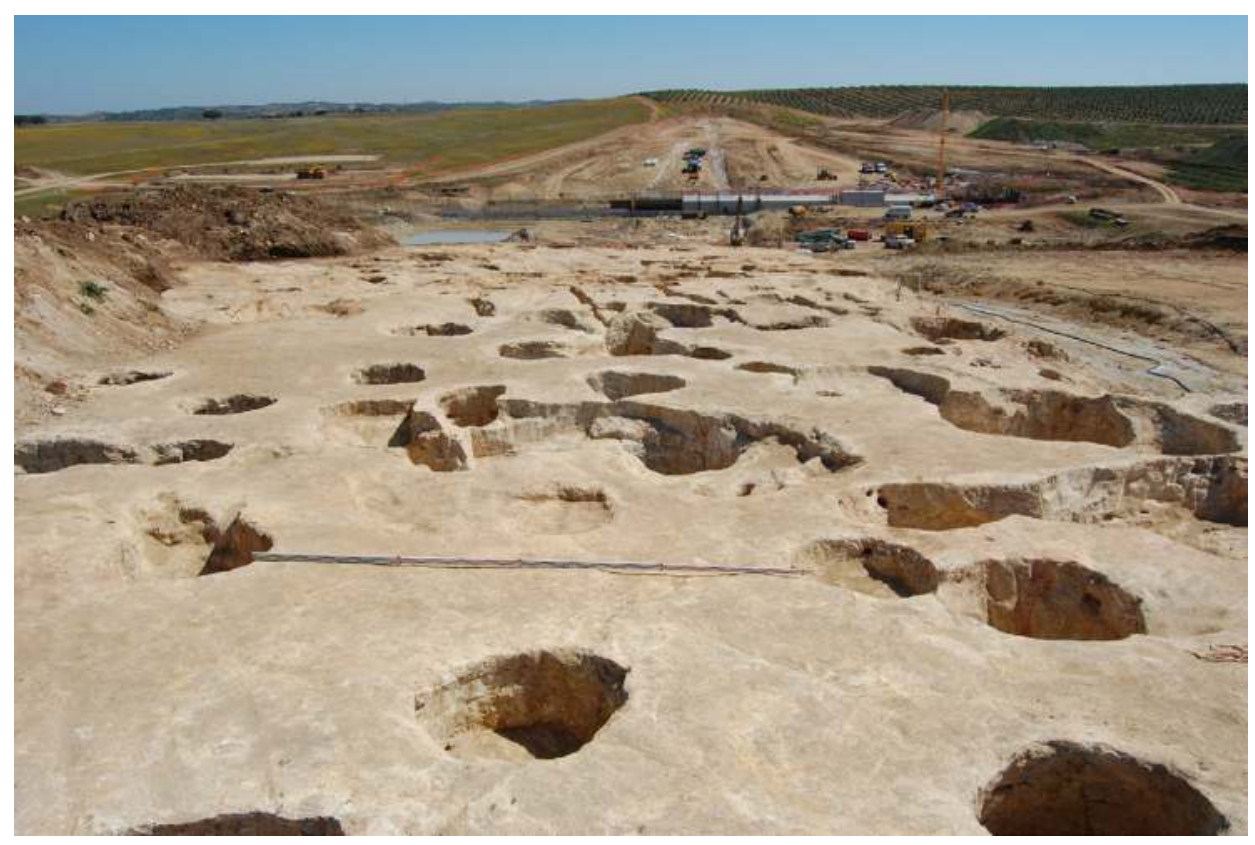

Figure 4. Torre Velha 3 (Serpa), open settlement (Palimpsesto, Lda.). 
Semi-Circulares

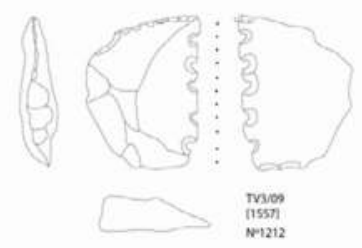

Sub-Rectångulares

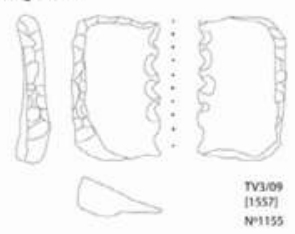

Triángulares/Sub-Triàngulares

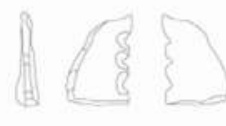

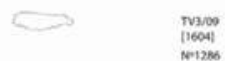

Trapezoidais

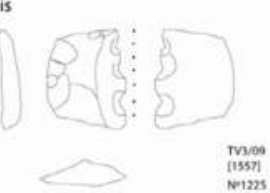

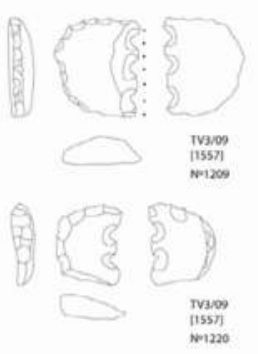

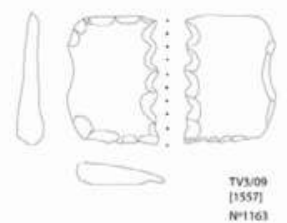

7voso

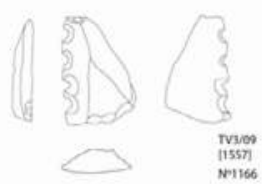

Sob-Làmina

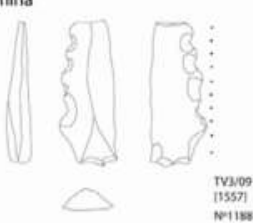

a

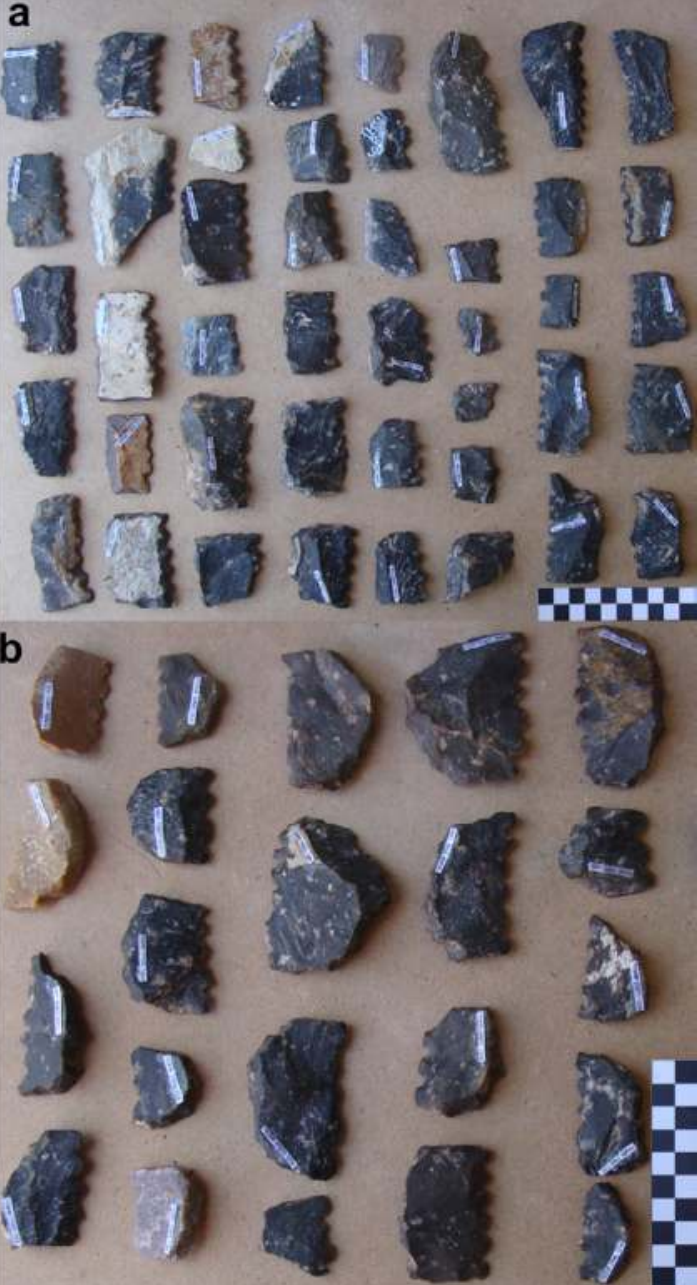

Figure 5. Sickle blades from pit 1722, Torre Velha 3 (Serpa) (Porfírio 2014: 46, fig. 9).

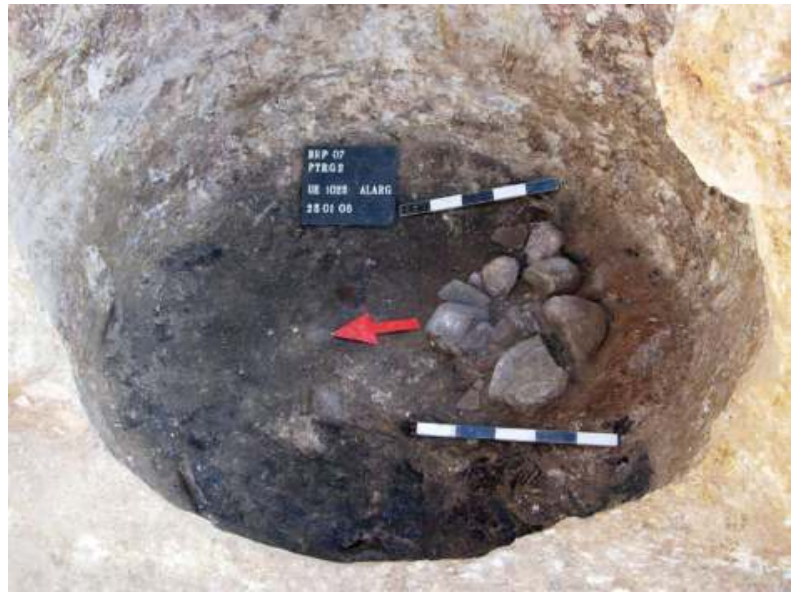

Figure 6. Pit with carbonised barley seeds, Pedreira de Trigaches 2 (Serpa) (Arqueologia e Património, Lda.). hypothesis that there is a certain degree of mobility or seasonality in the activities of these populations, an hypothesis reinforced by the presence of some pit settlements located in floodplain areas, which would mean abandoning them in periods of higher rainfall, as evidenced at the open settlement of Entre Águas 5 (Serpa), although it fits into LBA chronologies (Rebelo et al. 2009). The large numbers of pits at some of these sites may not mean a numerically important population, but rather a systematic return to the same sites, implying the sealing/abandonment of some pits and the opening of new ones with the returning of the community, an aspect that can be intuited by the existence of unfinished pits coinciding in part with existing ones, like at Torre Velha 3 (Alves et al. 2014: 105).

The existence of settlements on high places, fortified or not, during this period is yet to be proven. And while some investigators suggest their existence alongside open settlements, revealing a very hierarchical society (Soares and Silva 1995: 138), there is insufficient data 
to prove this. Despite the existence of the important site of El Cerro del Castillo de Alange (Extremadura, Spain), with clear affiliations to the SBA, and a clear and remarkable Middle Bronze Age occupation (Pávon 1998), we have to take into consideration its location within a peripheral region that might also have been influenced by other cultural areas. The archaeological excavations carried out at the main fortified LBA settlements of the Beja region (Castro de Ratinhos, Outeiro do Circo, Passo Alto, Mangancha), have not yet revealed previous occupations dated to other stages of the Bronze Age (Soares 2013).

Another important aspect concerns the presence of necropolises integrated within these settlements, either through the reuse of pits as graves or through the construction of hypogea. This scenario is indicative of a clear difference from cist necropolises, which are apparently separated from inhabited spaces. In fact, very few cases show evidence of domestic contexts near a cist necropolis, with the exception of a few on the Alentejo coast, such as Quitéria, Provença and Pessegueiro (Sines) (Silva and Soares 2009).

\section{Cists, hypogea, pits, niches}

The cist necropolises of the Beja region, recognised since the late 19th century, served during much of the archaeological research throughout the 20th century as synonymous with the regional Bronze Age itself, individualised, as noted, by Schubart in the so-called Southwestern Bronze Age.

The architectural simplification of the SBA funerary spaces brings us to new ways of interpreting the world in relation to what happened during the 3 rd millennium $\mathrm{BC}$, with the emerging presence of individual rather than places of collective burial: from tholoi, with tens or hundreds of burials, we have cists, mainly with individual burials, without monumental expression, but revealing a certain constructive variety. Consisting of simple slabs forming a rectangular box with lid, the cists in the Beja region form small necropolises scattered across the plain, without apparent volumetric prominence (Parreira 1998; Serra 2014a) (Figure 7).

However, this world of the dead also demonstrates the polymorphism that characterises the SBA, as there are also cases of cists clustering in stone enclosures or surrounded by a tumulus of stone and earth, giving it greater expression and visibility, e.g. at Talho do Chaparrinho (Serpa), where one of the cists is inserted in a cairn consisting of diorite blocks, delimited by schist slabs, and covered by milky-white rolled pebbles (Soares et al. 2009: 439) (Figure 8).

These cist necropolises are small in size, rarely exceeding a dozen graves, such as those at Monte do

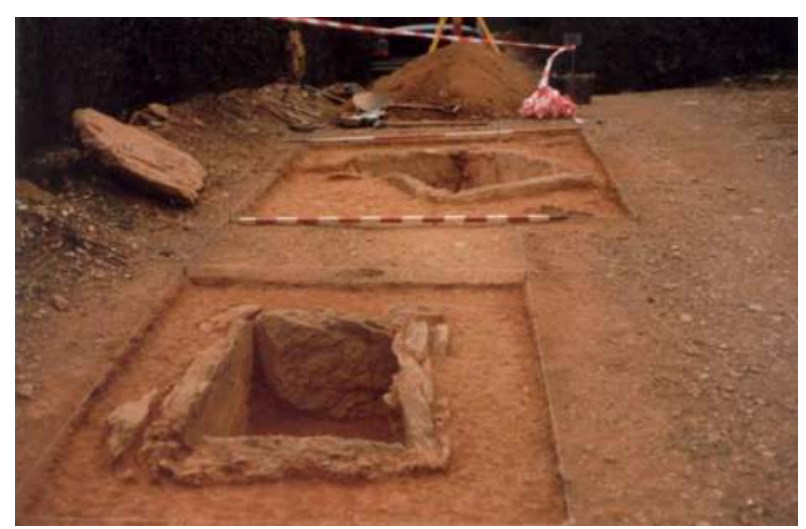

Figure 7. Bugalhos cist necropolis (Serpa) (António Monge Soares).

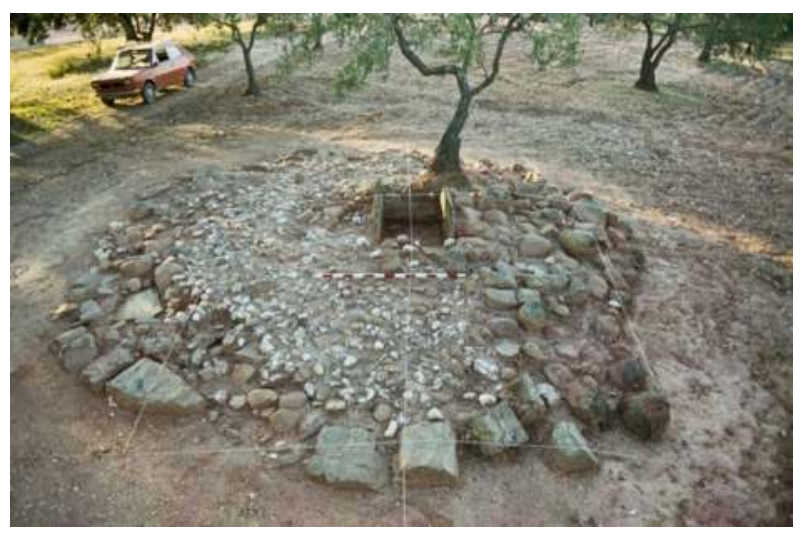

Figure 8. Talho do Chaparrinho (Serpa), cist with cairn (António Monge Soares).

Ulmo (16 cists) and Mós (10 cists), located near the village of Santa Vitória in the western Beja region (Serra 2014a: 275, 276). However, we must bear in mind that most of these necropolises were excavated in the 1950s and 1960s, and no exhaustive work has been done to allow us to know the full areas occupied by them.

The most recent works have not brought much news about these doubts, since there have been few cases of excavations of cists, and the few that have been the target of archaeological works were found in contexts of preventive archaeology where limitations are evident in the areas that can be excavated and thus greatly restricting our knowledge (Soares 2013: 296).

The apparent discretion of these necropolises is contradicted by the presence of stelae - known as Alentejo Slabs or type I stelae - which would indicate specific graves, serving as a visual reference (Gomes 2006; Serra et al. 2014). The most recent archaeological works have increased our knowledge of the funerary architectures of this period, which keep invisibility as their main feature, but taking completely different 


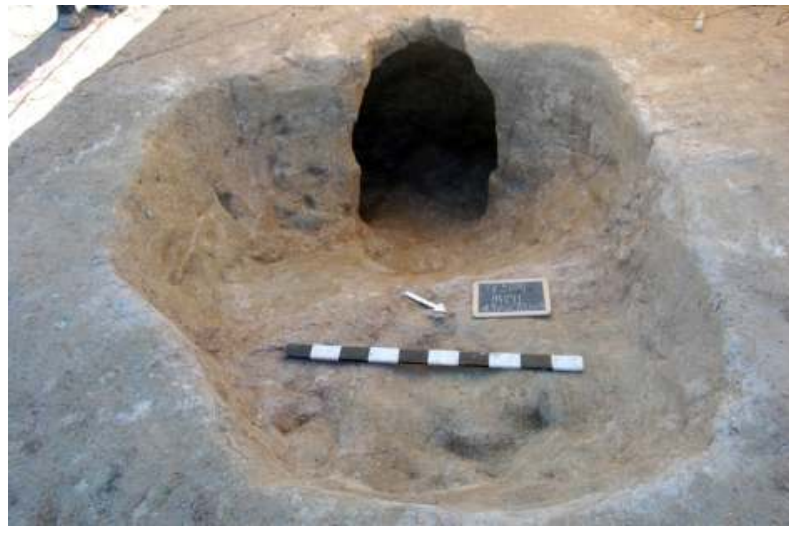

Figure 9. Torre Velha 3 (Serpa) hypogeum (Palimpsesto, Lda.).

forms, e.g. the hypogea, which have morphological variations, but which are generally composed of a sub-rectangular antechamber and an oval sepulchral chamber, with mainly individual or double burials (Alves et al. 2014: 107, fig. 7; Baptista et al. 2012: 152, table 1) (Figure 9).

The hypogea were already know in this territory, but were interpreted as exceptional cases related to the presence of communities linked to the Mediterranean world, as evidenced by the Belmeque (Serpa) hypogeum, where a double burial was detected with funerary offerings, considered as exogenous and related to the $\mathrm{El}$ Argar Culture (Soares 1994: 183). Although Belmeque's grave retains its exceptional character due to the funerary offerings therein, the funerary architecture of the hypogea is now known from dozens of other archaeological sites, with a special focus on the left bank of the Guadiana River, constituting a clear regional phenomenon.

Numerous individual burials, or doubles in rare cases, also appear in reused pits, where other variations can be found, such as the existence of niches excavated in the pit walls, used mainly for children's burials, like at Torre Velha 3 (Alves et al. 2010: 135) (Figures 10 and 11).

Many of these pit burials are difficult to assign chronologically, given the lack of associated offerings and the scarce radiometric dating available. Furthermore, we should also bear in mind that some pit burials, namely at the Monte da Cabida 3 and Horta do Albardão 3 (Évora) sites, provided dating within the LBA (Soares et al. 2009: 442), while the Torre Velha 3 (Serpa) pit burials, dated by radiocarbon, provided dates within the Full Bronze Age (Valério et al. 2014: 72, table 1).

However, during the LBA the funerary world becomes invisible in the archaeological record, revealing a new paradigm shift. In fact, the LBA necropolises remain largely unknown, and there is no correspondence

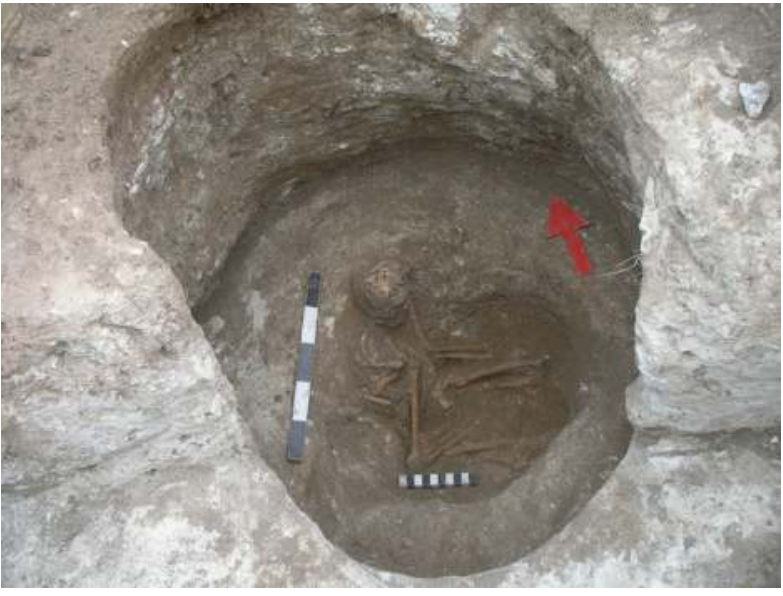

Figure 10. Pit burial at Horta do Jacinto (Beja) (Arqueologia e Património, Lda.).

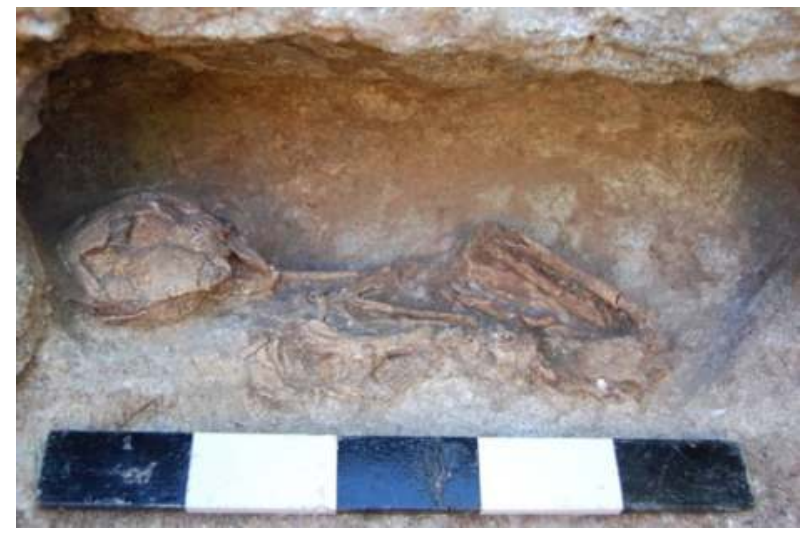

Figure 11. Children's burial in niche at Torre Velha 3 (Serpa) (Palimpsesto, Lda.)

between the constructive investment in inhabited spaces, clearly expressed in the construction of settlements surrounded by complex walls, and the funerary architectures (Serra 2014a: 283).

This scenario reinforces the idea of the existence of a multiplicity of funerary practices that do not always leave archaeological traces and that could include practices that are difficult to prove, performed in aquatic context, incineration, outdoors (i.e. the bodies consumed by wild animals), on pathways or places of occurrences of special significance (Vilaça 2006: 42-43).

An exception to this scenario is the case of Monte da Ramada 1 in Ervidel (Aljustrel, Beja), where two hypogea with several inhumations were detected, and which has provided absolute dates that fix them within the LBA, constituting a unique example so far in the record of the funeral practices of this period in the region. The Monte da Ramada 1 finds reveal, both the existence (or 
reuse) of a type of funerary architecture characteristic of the southwestern FBA, and with the practice of collective burials, although for the moment this remains an isolated case difficult to interpret (Baptista et al. 2018).

We should also not forget the large numbers of inhumations in pits that remain to be dated and that may in the future shed some light on the burial world of the LBA, since in nearby regions there is similar evidence dating from this period, as in the abovementioned necropolises of Casarão da Mesquita 3 and Horta do Albardão 3 (Évora) (Soares et al. 2009: 448). In summary, we can see a clear contrast between these two moments during the Bronze Age. To the variability of funerary practices, of the first phase, follows a certainly invisibility of the funerary world, when we enter the LBA.

It is difficult to give a single explanation for the reasons that justify the great polymorphism in the funerary practices during the Full Bronze Age, materialised in various orientations of the graves, distinctive architectural features, the body position, the number of buried individuals, the presence/absence and type of grave goods, among others considerations (Soares et al. 2009: 452). Some authors see in this polymorphism the reflex of several degrees of influence of local traditions, contacts between different regions and even the arrival of exogenous communities, in addition to social inequality, not just translated into richer/poor grave goods, but also regarding the access to certain funerary practices (Alves et al. 2012: 151; Martiniano et al. 2017: 12; Soares et al. 2009: 452).

If over the Full Bronze Age we can assume a major focus on the funerary world, as revealed by the grave/ necropolis being at the cohesive centre of these communities (Serra 2014a: 289), with the LBA we witness a huge change, symbolising the great transformations in the social framework steering to a stratified society. The consolidation and affirmation of warrior elites leads to the transfer of places of social cohesion, which abandons the practices in burial grounds, directing them within the walls of the settlements from which they exercise and display their power.

The apparent 'invisibility' of funerary practices during the LBA (Serra 2014a: 288) presents a subject about which we still have few explanations; the several cases, still rare, that arise, and the lack of radiometric dating of large quantities of inhumations, show us that, once again, diversity may be the rule.

\section{From plains to hills}

At the end of the 2nd millennium $\mathrm{BC}$, monumental constructions once again emerge in the Lower Alentejo setting, with the appearance of the large, fortified settlements that shape the LBA landscape. At the same time, there appears to be some regression of the lowland settlement, with fewer open settlements than in the previous period, which is very evident for the Beja region, where we have about 60 open settlements in the first phase of the Bronze Age, reducing to 14 for the LBA (Serra and Porfírio 2017: 227). This is certainly due to the phenomenon of population concentration exerted by the large fortified settlements (Serra 2014b: 83), that offer better protection, but also lead to the creation of wider units more capable of exploring and controlling larger territories, and thus becoming most imposing. For the elites who emerged during the LBA, population concentration on fortified settlements could also function as a way to exercise more efficient control through the organisation of the collective work force needed to build large walls and maintain them (Berrocal-Rangel and Silva 2010: 434), at the same time better displaying their power to an agglomerated population, rather than to several small communities. Additionally, an apparent instability/competition, or the need for communities to assert themselves by claiming certain sovereignty over the territory, leads to the construction of vast walls and complex defensive systems in the highest hills of this territory.

In the Beja region we can define a highly hierarchised settlement system, whose head is constituted by a large fortified settlement located in the hinterland, for example Outeiro do Circo, with its area of 17 ha (Serra 2014b) (Figure 12). The rest of the region is occupied by different types of settlements, following a strategy of control and exploration of the territory, with the emergence of settlements at high places located at important crossing zones near watercourses, surrounded by walls or not; at the same time there remain some lowland open settlements, maintaining the same characteristics as the open settlements of the previous period (Serra and Porfírio 2017) (Figure 13).

The focus on the individual assumes its greatest expression, but is shifted from the funeral ceremonial to the living places, making the world of the dead invisible to our eyes, probably due to changes in the burial practices whose evidence we recognise is unable to register.

This affirmation of a hierarchal society, led by warrior elites, is also evidenced by the increment of bronze metallurgy, also yielded inside the fortified settlements, like Outeiro do Circo, where there is also evidence of gold production (Valério et al. 2013: 612), and a possible growing instability, demonstrated by the frequency of weapons and other prestige goods in this territory, like the swords from Safara (Moura), probably an aquatic deposition related to public ceremonies, or 


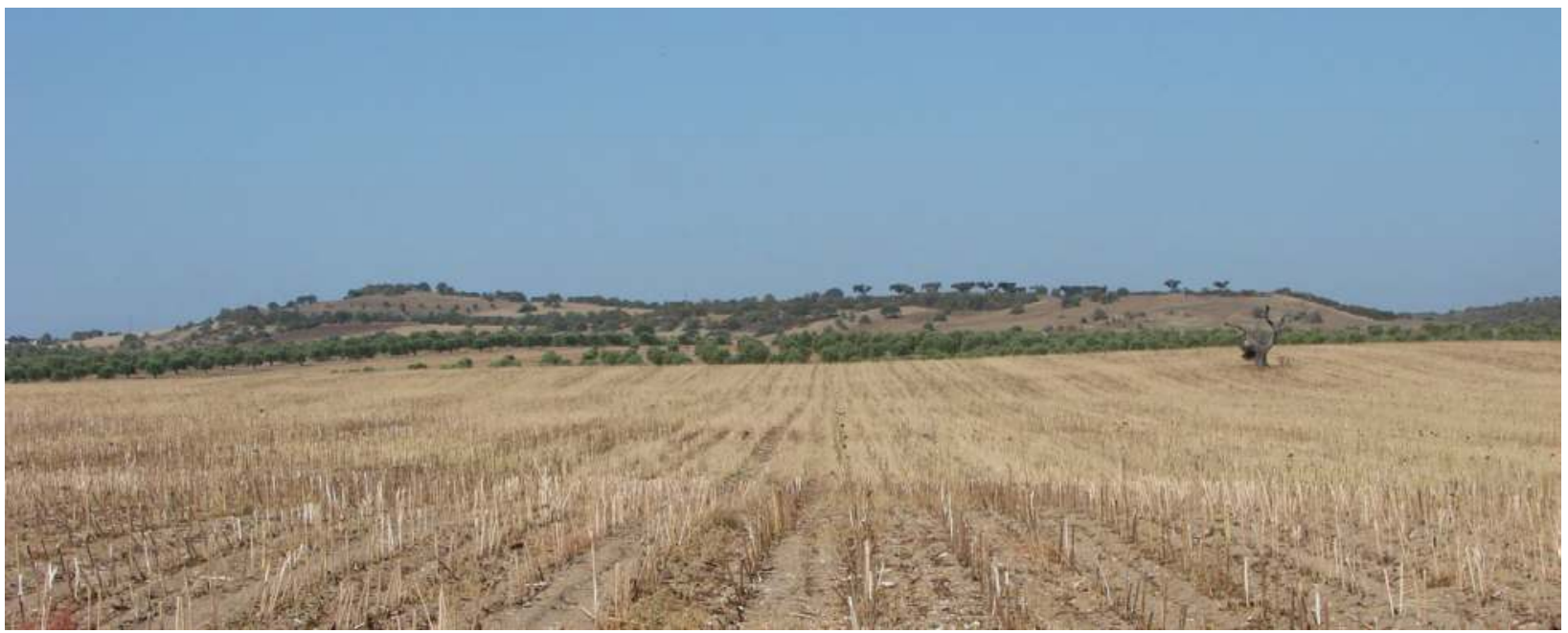

Figure 12. The Late Bronze Age fortified settlement of Outeiro do Circo (Beja) (Miguel Serra).

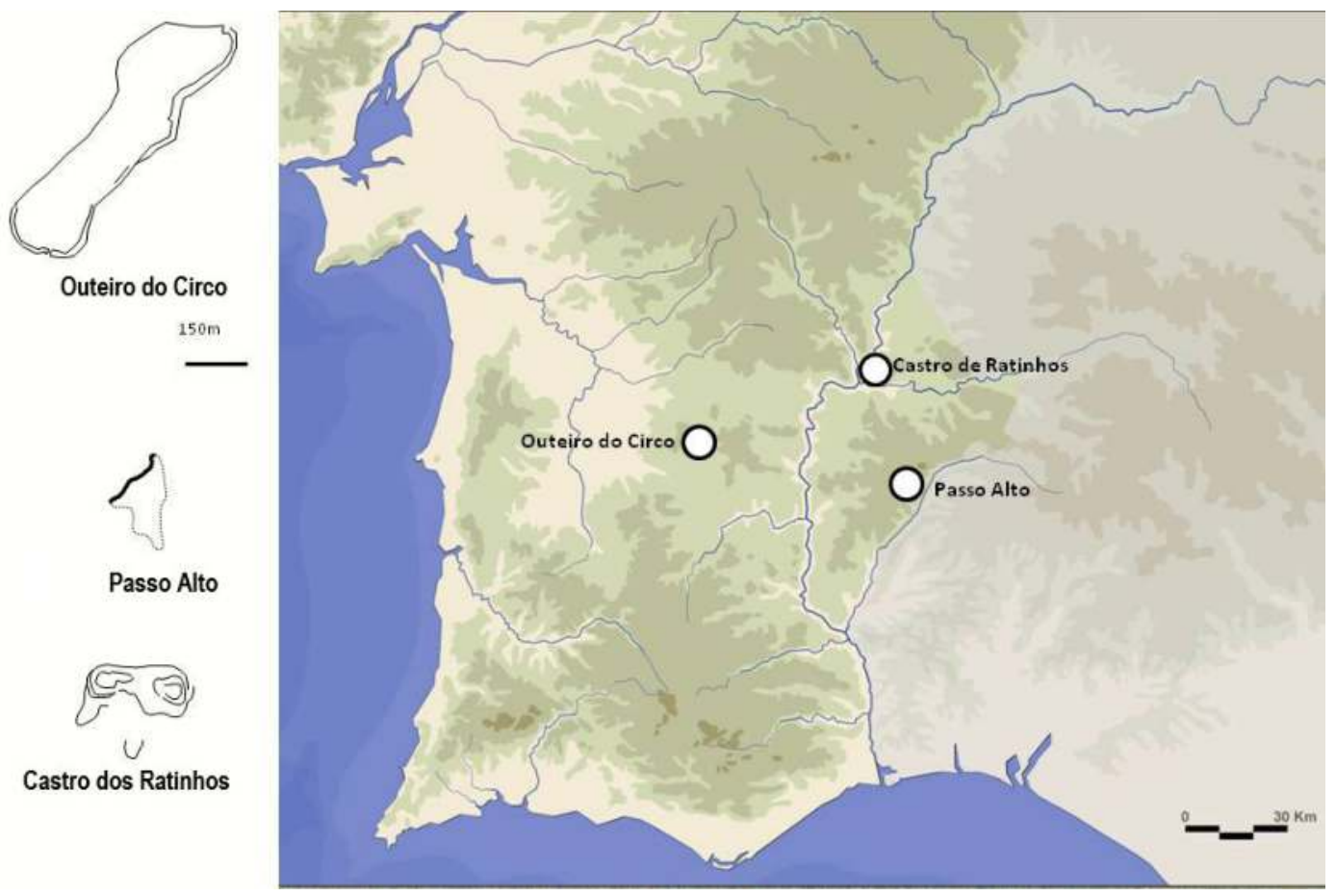

Figure 13. Location and plans of the main fortified Late Bronze Age settlements in the Beja region (Miguel Serra).

the spears from Alqueva, Serra de Borrazeiros, Castro de S. Bernardo, Beja and Albernoa, and the Warrior Stela of Ervidel II, with engravings of sword, spear and shield, that we can relate to ideological and symbolic manipulation of weapons as means of coercion or even violence. But also the exhibition of other goods was a part of the new social relations, in which the gold jewellery assumed particular relevance, finds of which are also present in this territory, like the necklace from Vila Nova de São Bento (Serpa), the bracelets from Aljustrel, the necklace and bracelet from the Baleizão hoard, the ring from Trindade (Beja), the buttons from Castro de Ratinhos (Moura), and the amazing hoard from Álamo (Moura) (Vilaça 2014: 113, 114).

Thus, we have for the final stage of the Bronze Age, a reality composed of a greater diversity in the forms of settlement implantation in the landscape, its dimension and its functionality, resulting from the specialisation, hierarchisation, and complexification of the society (Vilaça 1997: 132). 
If during the Full Bronze Age we see an homogeneous settlement system, centred on the plains, we now see increases in the occupation of the territory, with the settlements settling in all types of mountainous regions, highlighting the emergence of fortified settlements on higher ground (Serra and Porfírio 2018: 275; Soares 2013: 275), that will play the leading role in territory management until the beginning of the Iron Age, when we will again witness return to the plains and the entrance into a new worldview (Serra and Porfírio 2018: 47).

\section{Final remarks}

Entry into the 2nd millennium $\mathrm{BC}$ marks the abrupt end of the cosmological and social world that has been developing from the Late Neolithic to the Late Chalcolithic, as a result of unsustainable growth.

With the beginning, and first phase of the Bronze Age, huge changes occur on every level of society, from social and economic organisation to ideology, with clear indicators, in the lower Alentejo region, in the way the territory was shaped by architecture and forms of occupation. Social differentiation and the emergence of individuality make a progressive appearance throughout the Bronze Age, revealing a reorganisation of settlement patterns, new territorialities, and new funerary practices and meanings.

The first phases within the Bronze Age show the clear break from the previous model, with communities scattered along vast plain areas, instead of population concentration in large enclosures. We also find the adoption of individual burials associated with an individual assemblage of votive offerings, e.g. weapons, instead of large collective tombs with their complex practices, among many other aspects that show evidence of a new form of social organisation presaging the progressive emergence of some specific individuals who achieve prominence and relevant status over a fragmented society.

The lack of data does not yet allow us to confirm whether the social organisation of this period developed in more complex forms, for instance in a less homogeneous settlement system, materialised in the eventual appearance of larger settlements, fortified or not, on higher places, as we have witnessed in other regions within the geographical framework of the Iberian SBA.

However, the social inequality intuited from a funerary record that shows different architectures, offerings, and access to some funerary practices, and the growing role of weapons, evidence a clear path towards individualisation and hierarchisation, which will ultimately steer this society to new and great changes by the end of the 2nd millennium $\mathrm{BC}$, congregating in vaster settlements surrounded by walls, attributing to the domestic space a new centrality in ways of power exhibition and social emulation at the expense of funerary space, which remains relatively unknown.

The works conducted in this region over the last two decades have led to the acquisition of gigantic datasets that, for the most part, remain to be properly studied and that will have to be complemented with greater analytical and interdisciplinary work to enable us to access more accurately the reasons that motivated the pathways taken by these communities.

\section{References}

Alves, C., Costeira, C., Estrela, S., Porfírio, E., Serra, M., Soares, A.M. and Moreno-García, M. 2010. Hipogeus funerários do Bronze Pleno da Torre Velha 3 (Serpa, Portugal). O Sudeste no Sudoeste?! Zephyrus LXVI: 133-153.

Alves, C., Costeira, C., Estrela, S., Porfírio, E., Serra, M., Soares, A.M. and Moreno-García, M. 2014. Caracterização preliminar da ocupação préhistórica da Torre Velha 3 (Barragem da Laje, Serpa), in $4^{\circ}$ Colóquio de Arqueologia do Alqueva. O Plano de Rega (2002-2010): 103-111. Memórias d'Odiana, $2^{\mathrm{a}}$ Série. Estudos Arqueológicos do Alqueva 14. Évora: Universidade de Évora.

Antunes, A.S., Deus, M., Soares, A.M., Santos, F., Arêz, L., Dewulf, J., Baptista, L. and Oliveira, L. 2021. Povoados abertos do Bronze Final no Médio Guadiana, in J. Jímenez Ávila, J. (ed.) Sidereum Ana - El río Guadianaen el Bronce Final: 277-308. Anejos AEspA LXII. Mérida: Instituto de Arqueología de Mérida.

Baptista, L., Rodrigues, Z. and Pinheiro, R. 2012. Espacialidades dos cadáveres em Montinhos 6: contributos para uma compreensão das práticas funerárias da Idade do Bronze no Sudoeste Peninsular, in Actas do V Encontro de Arqueologia do Sudoeste Peninsular: 149-170. Câmara Municipal de Almodôvar.

Baptista, L., Soares, A.M., Rodrigues, Z., Vale, N., Pinheiro, R., Fernandes, S. and Valério, P. 2018. Os hipogeus funerários do Bronze Final do Sudoeste do Monte da Ramada 1 (Ervidel, Aljustrel). Estudo Preliminar, in Actas do VIII Encontro de Arqueologia do Sudoeste Peninsular: 265-288. Câmara Municipal de Serpa.

Berrocal-Rangel, L. and Silva, A.C. 2010. O Castro dos Ratinhos (Barragem do Alqueva, Moura). Escavações num povoado proto-histórico do Guadiana 20042007. O Arqueólogo Português, Suplemento 6.

Gomes, M.V. 2006. Estelas funerárias da Idade do Bronze Médio do Sudoeste Peninsular. A iconografia do Poder, in Actas do VIII Congresso Internacional de Estelas Funerárias: 47-62. O Arqueólogo Português - Suplemento 3. Lisboa: Museu Nacional de Arqueologia. 
Martiniano, R., Cassidy, L., Ó`Maoldúin, R., McLaughlin, R., Silva, N., Manco, L., Fidalgo, D., Pereira, T., Coelho, M., Serra, M., Burger, J., Parreira, R., Moran, H., Valera, A., Porfírio, E., Boaventura, R., Silva, A. and Bradley, D. 2017. The population genomics of archaeological transition in west Iberia: investigation of ancient substructure using imputation and haplotype-based methods. PLOS Genetics. 13.7 (July 27, 2017): 1-24.

Mataloto, R., Martins, J. and Soares, A.M. 2013. Cronologia absoluta para o Bronze do Sudoeste. Periodização, base de dados, tratamento estatístico. Estudos Arqueológicos de Oeiras 20: 303-338.

Parreira, R. 1995. Aspectos da Idade do Bronze no Alentejo Interior, in S. Jorge (ed.) A Idade do Bronze em Portugal - discursos de poder: 131-134. Lisboa: Instituto Português de Museus, Museu Nacional de Arqueologia.

Parreira, R. 1998. As arquitecturas como factor de construção da paisagem na Idade do Bronze do Alentejo Interior, in S. Jorge (ed.) Existe uma Idade do Bronze Atlântico?: 267-273. Trabalhos de Arqueologia 10. Lisboa: Instituto Português de Arqueologia.

Parreira, R. 2014. O Bronze do Sudoeste como entidade arqueográfica: a visibilidade dos dados empíricos e os resultados da pesquisa como produto social, in $\mathrm{R}$. Vilaça and M. Serra (eds) A Idade do Bronze do Sudoeste - Novas perspectivas sobre uma velha problemática: 1323. Coimbra: Instituto de Arqueologia da Faculdade de Letras da Universidade de Coimbra, Centro de Estudos em Arqueologia, Artes e Ciências do Património, Palimpsesto, Lda. (http://www.uc.pt/ fluc/iarq/pub_online/).

Pavón Soldevila, I. 1998. El Cerro del Castillo de Alange (Badajoz). Intervenciones Arqueológicas (1993). Memorias de Arqueología Extremeña 1.

Pereiro, T., Estrela, S., Porfírio, E. and Serra, M. 2012. Torre Velha 3 (Serpa): dados preliminares do estudo da indústria de pedra lascada. O caso da estrutura negativa [1722]. Arqueologia e História 62-63: 51-63.

Porfírio, E. 2014. O povoamento aberto no Bronze Pleno do Sudoeste. Algumas reflexões a partir do sítio de Torre Velha 3 (Serpa), in R. Vilaça and M. Serra (eds) A Idade do Bronze do Sudoeste - Novas perspectivas sobre uma velha problemática: 23-47. Coimbra: Instituto de Arqueologia da Faculdade de Letras da Universidade de Coimbra, Centro de Estudos em Arqueologia, Artes e Ciências do Património, Palimpsesto, Lda. (http://www.uc.pt/fluc/iarq/pub_online/).

Rebelo, P., Santos, R., Neto, N., Fontes, T., Soares, A.M., Deus, M. and Antunes, A. 2009. Dados preliminares da intervenção arqueológica no sítio do Bronze Final de Entre Águas 5 (Serpa), in Actas IV Encuentro de Arqueología del Suroeste Peninsular: 463-471. Huelva: Universidad de Huelva.

Ribeiro, F.N. 1965. O Bronze Meridional Português. Beja: Subsidiada pela Junta Distrital de Beja.

Schubart, H. 1965. Atalaia. Uma necrópole da Idade do Bronze do Baixo Alentejo. Arquivo de Beja 22: 7-136.
Schubart, H. 1971a. Acerca de la ceramica del Bronce Tardio en el Sur y Oeste Peninsular. Trabajos de Prehistoria 28: 153-182.

Schubart, H. 1971b. O Horizonte de Ferradeira: Sepulturas do eneolítico final no Sudoeste da península Ibérica. Revista de Guimarães 81(3-4): 189215.

Schubart, H. 1975. Die Kultur der Bronzezeit in Sudwesten der Iberischen Halbinsel. Berlin: Walter de Gruyter \& co.

Serra, M. 2014a. Os senhores da planície. A ocupação da Idade do Bronze nos 'Barros de Beja' (Baixo Alentejo, Portugal). Antrope - Série Monográfica 1: 270-297.

Serra, M. 2014b. Muralhas, Território, Poder. O papel do povoado do Outeiro do Circo (Beja) durante o Bronze Final, in R. Vilaça and M. Serra (eds) A Idade do Bronze do Sudoeste - Novas perspectivas sobre uma velha problemática: 75-99. Coimbra: Instituto de Arqueologia da Faculdade de Letras da Universidade de Coimbra, Centro de Estudos em Arqueologia, Artes e Ciências do Património, Palimpsesto, Lda. (http://www.uc.pt/fluc/iarq/pub_online/).

Serra, M. and Porfírio, E. 2012. O Bronze Final nos ‘Barros de Beja'. Novas perspectivas de investigação, in Actas do V Encontro de Arqueologia do Sudoeste Peninsular: 133-148. Câmara Municipal de Almodôvar.

Serra, M., and Porfírio, E. 2017. Estratégias de povoamento entre o Bronze Pleno e Final na região de Beja, in Actas do III Congresso Internacional de Arqueologia de Transição -Estratégias de Povoamento: da Pré-história à Proto-história: 209-232. Scientia Antiquitatis 1.1. Évora: Universidade de Évora.

Serra, M. and Porfírio, E. 2018. A Idade do Bronze pelas planícies de Ferreira do Alentejo, in Ferreira 5000 anos de história. Comemoração dos 500 anos do foral manuelino de Ferreira do Alentejo: 31-50. Câmara Municipal de Ferreira do Alentejo.

Serra, M., Porfírio, E. and Soares, S. 2014. A estela da Idade do Bronze do Monte do Ulmo (Santa Vitória, Beja). Conimbriga LIII: 5-30.

Silva, C.T. and Soares, J. 2009. Práticas funerárias no Bronze Pleno do Litoral Alentejano: o monumento II do Pessegueiro. Estudos Arqueológicos de Oeiras 17: 389-420.

Soares, A.M. 1994. O Bronze do Sudoeste na Margem Esquerda do Guadiana. As Necrópoles do Concelho de Serpa, in Actas das V Jornadas Arqueológicas: 179-197. Lisboa: Associação dos Arqueólogos Portugueses.

Soares, A.M. 2013. O sistema de povoamento do Bronze Final no Baixo Alentejo - Bacia do Guadiana. Estudos Arqueológicos de Oeiras 20: 273-302.

Soares, A.M., Santos, F., Dewulf, J., Deus, M. and Antunes, A. 2009. Práticas Rituais no Bronze do Sudoeste Alguns dados. Estudos Arqueológicos de Oeiras 17: 433456.

Soares, J. and Silva, C.T. 1995. O Alentejo Litoral no contexto da Idade do Bronzr do Sudoeste Peninsular. In S.Jorge. (ed.) A Idade doBronze em Portugal-discursos 
de poder: 136-139. Lisboa: Instituto Português de Museus, Museu Nacional de Arqueologia.

Valera, A.C. 2013. Recintos de fossos da Pré-História Recente em Portugal. Investigação, discursos, salvaguarda e divulgação. Al-madan, 2ª série 18: 93110.

Valera, A.C. 2014. Continuidades e descontinuidades entre o $3^{\circ}$ e a primeira metade do $2^{\circ}$ milénio a.n.e. no Sul de Portugal: alguns apontamentos em tempos de acelerada mudança. Antrope - Série Monográfica 1: 297-316.

Valera, A.C. 2015a. Social change in the late 3rd millennium $\mathrm{BC}$ in Portugal: the twilight of enclosures, in H. Meller, W. Arz, R. Jung and R. Risch (eds) $2200 \mathrm{BC}$ - A climatic breakdown as a cause for the collapse of the old world?: 409-427. $7^{\text {th }}$ Archaeological Conference of Central Germany. Tagungen des Landesmuseums fur Vorgeschichte Halle, Band 12/I. Halle: Landesmuseums fur Vorgeschichte.

Valera, A.C. 2015b. Map of walled and ditched enclosures, in http://portugueseenclosures.blogspot.pt/ (last update: February 2015).

Valera, A.C. 2018. Ferreira do Alentejo no contexto dos recintos de fossos pré-históricos do interior alentejano, in Ferreira: 5000 anos de história. Comemoração dos 500 anos do foral manuelino de Ferreira do Alentejo: 7-30. Câmara Municipal de Ferreira do Alentejo.

Valera, A.C. and Pereiro, T. 2015. Os recintos de fossos da Salvada e Monte das Cabeceiras 2 (Beja, Portugal), in N. Medina Rosales (ed.) Actas del VII Encuentro de Arqueología del Suroeste Peninsular: 315-327. Aroche: Ayuntamiento de Aroche.

Valério, P., Soares, A.M., Araújo, M.F., Silva, R., Porfírio, E. and Serra, M. 2013. Estudo de metais e vestígios de produção do povoado fortificado do Bronze Final do Outeiro do Circo (Beja), in Arqueologia em Portugal 150 anos - Atas do I Congresso da Associação dos Arqueólogos Portugueses: 609 - 615. Lisboa: Museu Nacional de Arqueologia.

Valério, P., Soares, A.M., Araújo, M.F., Silva, R., Porfírio, E. and Serra, M. 2014. Arsenical copper and bronze in Middle Bronze Age burial sites of southern Portugal: the first bronzes in Southwestern Iberia. Journal of Archaeological Science 42: 68-80.

Viana, A. 1955. Notas históricas, arqueológicas e etnográficas do Baixo Alentejo. Arquivo de Beja 12(14): 3-167.

Viana, A. 1956. Notas históricas, arqueológicas e etnográficas do Baixo Alentejo. Arquivo de Beja 13(14): 110-167.

Vilaça, R. 1997. Das primeiras comunidades humanas à chegada dos romanos, in M.C. Lopes, P. Carvalho and S. Gomes (eds) Arqueologia do Concelho de Serpa: 127133. Câmara Municipal de Serpa.

Vilaça, R. 2006. Proto-História Peninsular: programa, metodologia, conteúdos e guia bibliográfico. Textos Pedagógicos e Didáticos 16. Coimbra: Faculdade de Letras da Universidade de Coimbra.

Vilaça, R. 2014. Ensaio sobre a região de Beja em torno do ano mil a.C. Entre a tradição e a inovação, in R. Vilaça and M. Serra (eds) A Idade do Bronze do Sudoeste - Novas perspectivas sobre uma velha problemática: 101125. Coimbra: Instituto de Arqueologia da Faculdade de Letras da Universidade de Coimbra, Centro de Estudos em Arqueologia, Artes e Ciências do Património, Palimpsesto, Lda. (http://www.uc.pt/ fluc/iarq/pub_online/). 


\title{
Chapter 8 \\ Human/Animal Interactions at the Turn of the 3rd to the 2nd Millennium BC. Zooarchaeological Data from Inner Alentejo, Portugal
}

\author{
Cláudia Costa \\ ICArEHB Interdisciplinary Centre for Archaeology and Evolution of Human Behaviour, University of Algarve \\ Campus de Gambelas, Ed. 1, Faro, Portugal \\ cmcosta@ualg.pt
}

\begin{abstract}
In this paper we review and discuss data on the management of mammals in the middle 3rd and middle 2nd millennia $B C$ in inner Alentejo (Portugal), with a view to assessing whether there are significant changes in man-animal interactions at the turn of 3rd to the 2nd millennium BC. Despite the lack of absolute dating on 2nd millennium BC contexts, one can tell that there is an effective change in mammal management at the turn of the second millennium BC. In fact, during the 3rd millennium BC, suids dominate the archaeological record in dwelling contexts, whereas in the 2nd millennium they are replaced with domestic caprines. Regarding funerary contexts, 3rd-millennium BC faunal integration is dominated by carnivores, mainly canids and random anatomical parts of other species; and in the 2nd millennium BC, the diversified list of species is replaced by a monotonous dominance of front-limb cattle segments.

It is difficult to say how, why and when this change in mammal exploitation took place. It can be related to the $4.2 \mathrm{ky} \mathrm{BP} \mathrm{climatic}$ event that caused a decrease of Mediterranean forest in the southern Iberian Peninsula, or to social and cultural changes that took place at the end of the 3rd millennium $\mathrm{BC}$, or both. A new paradigm seems to arise within middle 2nd-millennium $\mathrm{BC}$ communities, where the hunting of larger animals is abandoned, suids lose value, caprids affirm their preponderance in dwelling contexts, and cattle acquire symbolic value within funerary practices.
\end{abstract}

Keywords: 3rd millennium BC, middle 2nd millennium BC, Inner Alentejo, mammal management, dwelling contexts, funerary contexts.

\section{Introduction}

Due to rescue archaeology undertaken during the last few years in inner Alentejo (southern Portugal; Figure 1), there was a huge increase of data related to recent prehistory occupation in this region. Although not all archaeological sites have yielded faunal remains, publications, and data on exploitation of vertebrates during the Chalcolithic (end of the 4th - end of the 3rd millennium BC) and Middle Bronze Age (common Bronze Pleno: first half of the 2nd millennium BC) have proliferated. Despite a clear discrepancy in the amount of available data between the Chalcolithic and Bronze Age, a trend can be seen regarding the evolution of species management, especially mammals, both in funerary and non-funerary contexts.

Recently, a state-of-the-art revision was published by Portuguese colleagues regarding the trend of mammal exploitation from central and southern Portugal, from the Early Neolithic to the Early Bronze Age (Valente and Carvalho 2019). As well as the long time span that paper addresses, the overview is centred on a very wide region: Portuguese Estremadura (central Portugal) and Alentejo (southern Portugal); it also relates animal exploitation exclusively with the economy, namely with Sherratt's 'Secondary Products
Revolution'(1981). From the present author's point of view, analysis of the evolution of mammal exploitation in a certain time span can be more insightful iffocused on a regional scale.

This contribution records trends observed in mammal exploitation at the turn of the $3 r d$ to the 2 nd millennium $B C$ in a particular region - inner Alentejo, southern Portugal - and relates these trends to the 4.2 ky climatic event effects.

\section{Faunal remains from dwelling and funerary contexts.}

Sites prone to preserve good faunal assemblages are the ones characterised by negative structures, such as diches, pits and hypogea. Dwelling contexts are those that do not contain human burials and include ditches and pits; funerary contexts include dolmens, tholoi, hypogea and pits with human burials (Table 1).

Inner Alentejo corresponds roughly to the hydrographic basin of the Guadiana River, delimited to the north by the Serra de São Mamede mountains and to the south by the Serra do Caldeirão ranges (Figure 1). Alto do Brinches 3 (Alves et al. 2014a) and Torre Velha 12 (Gomes et al. 2012) are sites with occupations dated from the 3rd millennium BC and the first half of 2 nd millennium $\mathrm{BC}$, and for both chronologies systematic publications 
Table 1. Mammal frequencies in Chalcolithic dwelling contexts.

\begin{tabular}{|l|l|l|l|l|l|l|l|}
\hline & Equussp. & $\begin{array}{l}\text { Sus } \\
\text { sp. }\end{array}$ & $\begin{array}{l}\text { Cervus } \\
\text { elaphus }\end{array}$ & $\begin{array}{l}\text { Bos } \\
\text { sp. }\end{array}$ & $\begin{array}{l}\text { Ovis/ } \\
\text { Capra }\end{array}$ & Leporidae & References \\
\hline Montoito 2 & $0.8 \%$ & $47 \%$ & $26 \%$ & $14 \%$ & $13 \%$ & $0 \%$ & Costa and Mataloto 2017 \\
\hline Porto Torrão & $3 \%$ & $37 \%$ & $6 \%$ & $25 \%$ & $22 \%$ & $8 \%$ & Pereira 2016 \\
\cline { 2 - 7 } & $1.5 \%$ & $43 \%$ & $2,2 \%$ & $29 \%$ & $19 \%$ & $0.8 \%$ & Arnaud 1993 \\
\hline Paraíso & $4 \%$ & $27 \%$ & $3 \%$ & $20 \%$ & $41 \%$ & $1 \%$ & $\begin{array}{l}\text { Mataloto et al. 2012 Davis and } \\
\text { Mataloto 2012 }\end{array}$ \\
\hline Monte da Tumba & $1 \%$ & $36 \%$ & $12 \%$ & $7 \%$ & $24 \%$ & $13 \%$ & Antunes 1987 \\
\hline Mercador & $9 \%$ & $35 \%$ & $25 \%$ & $14 \%$ & $11 \%$ & $5 \%$ & Moreno Garcia 2013 \\
\hline Casa Branca 7 & $0 \%$ & $29 \%$ & $1 \%$ & $13 \%$ & $29 \%$ & $26 \%$ & Costa 2006 \\
\hline São Pedro Redondo & $5 \%$ & $37 \%$ & $36 \%$ & $8 \%$ & $9 \%$ & $4 \%$ & Davis and Mataloto 2012 \\
\hline $\begin{array}{l}\text { Perdigões, (Fossos 1, 3, }+ \\
\text { fossas sector I) }\end{array}$ & $3 \%$ & $48 \%$ & $13 \%$ & $15 \%$ & $15 \%$ & $5 \%$ & $\begin{array}{l}\text { Costa 2010 } \\
\text { Costa 2013 }\end{array}$ \\
\hline Alto do Brinches 3 & $0 \%$ & $17 \%$ & $16 \%$ & $10 \%$ & $45 \%$ & $1 \%$ & Delicado et al. 2017 \\
\hline Torre Velha 12 & $0 \%$ & $21 \%$ & $8 \%$ & $28 \%$ & $40 \%$ & $3 \%$ & Senra 2018 \\
\hline Porto das Carretas & $11 \%$ & $21 \%$ & $17 \%$ & $37 \%$ & $10 \%$ & $1 \%$ & Cardoso 2013 \\
\hline
\end{tabular}

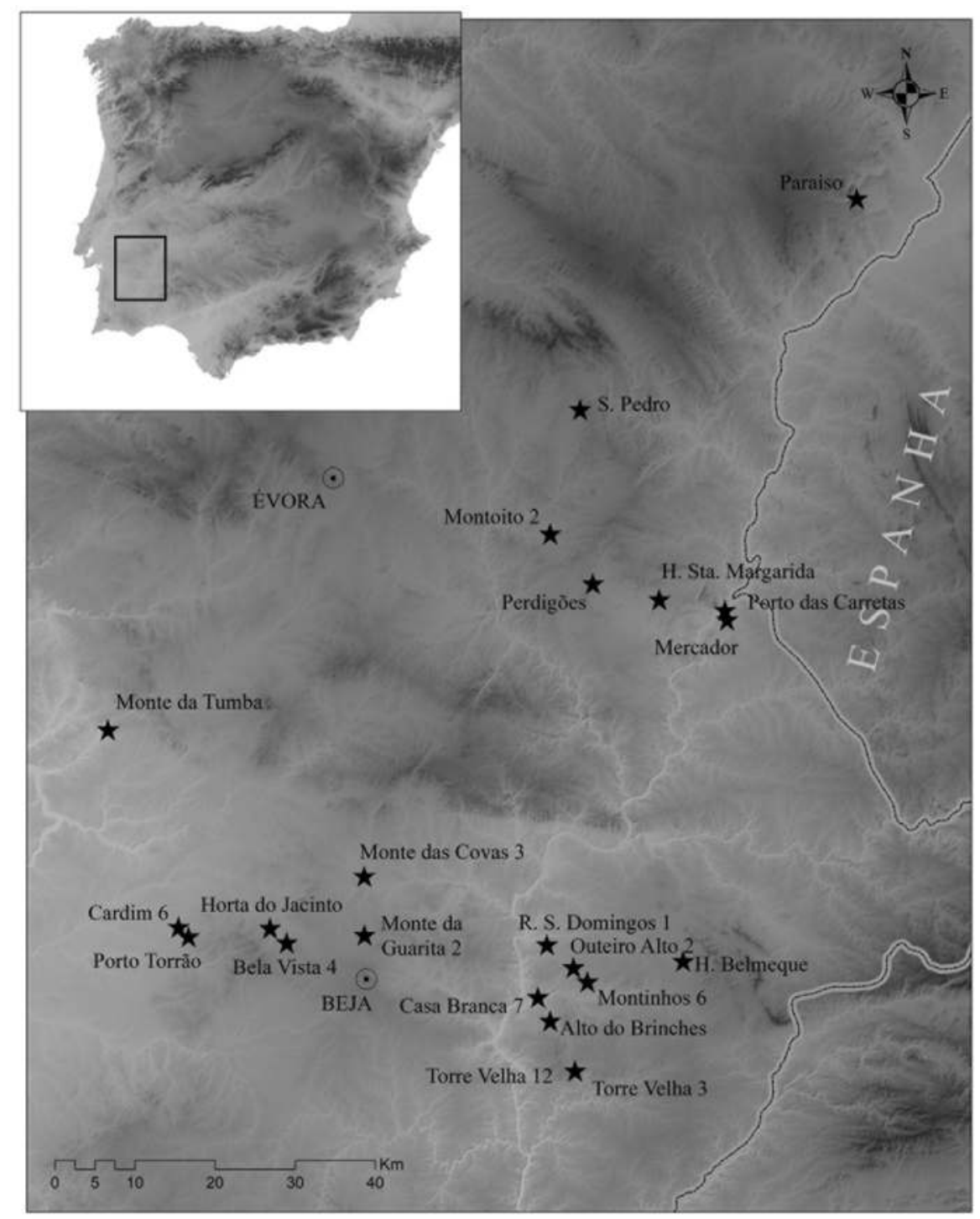

Figure 1. Map with sites considered in the text. 
of the faunal assemblages are available (respectively Delicado et al. 2017 and Senra 2018). Faunal remains from Perdigões (Lago et al. 1998), Montoito 2 (Valera et al. 2014), Porto Torrão (Arnaud 1993), Paraíso (Mataloto and Costeira 2008), Monte da Tumba (Silva and Soares 1987), Mercador (Valera 2013), Casa Branca 7 (Rodrigues 2006), São Pedro (Mataloto et al. 2007), and Porto das Carretas (Soares 2013) have also had their Chalcolithic layers' faunal assemblages published (Antunes 1987; Arnaud 1993; Cardoso 2013; Costa 2010; 2013; Costa and Mataloto 2007; Davis and Mataloto 2012; Delicado et al. 2017; Pereira 2016). It is important to note that there are only three sites dating from the 2nd millennium $\mathrm{BC}$, whereas 11 from the 3rd millennium $\mathrm{BC}$ have been traced: even so a trend can be seen.

Montoito 2, Porto Torrão, Paraíso and Perdigões, here considered as dwelling contexts, are ditched enclosures with generic chronologies spanning from the second half of the 4th (such as Perdigões) to the end of the 3rd millennium BC. São Pedro do Redondo, Monte da Tumba and Porto das Carretas are walled enclosures (sites generally located on hilltops with surrounding stone walls). Alto do Brinches 3, Torre Velha 12 and Mercador are pit camps (sites located in lowlands, apparently with no positive structure and composed simply of several negative structures, such as pits), also considered as dwelling contexts. As to Casa Branca 7, it is the only site with no negative structures, comprising two circular stone huts.

The 3rd-millennium funerary contexts considered here include one dolmen, Herdade de Santa Margarida 3 (Gonçalves 2003), four tholoi: tholos 1 and 2 of Perdigões (Valera et al. 2000), Cardim 6 (Valera et al. 2019) and Monte da Guarita 2 (unpublished). Sites with one pit each are also considered here: Monte das Covas 3 and Ribeira de São Domingos (Valera and Costa 2013). There is also one hypogeum, Bela Vista 4 (Valera and Costa 2013). Funerary 2nd-millennium BC contexts with faunal remains include five hypogea sites, e.g. Torre Velha 3 (Alves et al. 2010, 2014b), Torre Velha 12 (Gomes et al. 2013), Montinhos 6 (Baptista et al. 2012a), Outeiro Alto 2 (Filipe et al. 2013), Herdade de Belmeque (Soares 1994), and two pits with human burials associated with fauna, pit FE152 at Montinhos 6 (Costa et al. in preparation) and Horta do Jacinto (Baptista et al. 2012b).

The available data demonstrate that, regardless of living contexts, the predominance of suids in the 3rd millennium $B C$ is replaced by domestic caprines in the subsequent period. As for votive fauna in funerary contexts, there is also a difference: in the 3rd millennium $\mathrm{BC}$ there is a diversified list of species and random anatomical parts, while in the 2nd millennium BC this list is replaced by the monotonous predominance of cattle. Thus, this present study aims to demonstrate that at the turn of the $3 \mathrm{rd} /$ beginning of the 2 nd millennium BC in inner Alentejo (southern Portugal) there is a difference in terms of mammal management - whether in funerary or non-funerary contexts.

\section{Results}

\section{3rd millennium $B C$}

As shown in Table 1, mammal species in the 3rd millennium $B C$ sites are varied, with suids (Sus sp.) being the best represented group, followed by domestic caprines (Ovis/Capra) and bovids, the latter including both wild (Bos primigenius) and domestic (Bos taurus) forms. Wild species are well represented and include red deer (Cervus elaphus), equids (Equus sp.) and leporids (hare and rabbit). Except for Paraíso, São Pedro do Redondo, Alto do Brinches 3, Torre Velha 12 and Porto das Carretas, suids are the best represented species, followed by caprines and cattle; at Paraíso, Alto do Brinches 3 and Torre Velha 12, caprines are in the majority, but in Porto das Carretas bovids are the best represented; and at Casa Branca 7 the percentages of suids and caprines are equal.

Regarding the percentages of domestic caprines and cattle, there is a well-established domestic economy, although the hunting of horses, red deer and leporids is a very important activity.

As for funerary contexts, the votive fauna is varied, with a vast bias towards carnivores (mostly canids), that tend to appear isolated inside tholoi, dolmens, pits, and hypogea (Table 2). Regarding anatomical representation, a preference for the deposition of articulated limb segments or bones from the limbs is observed (Valera and Costa 2013), although bones from crania and torso can also be found.

\section{2nd millennium $B C$}

Until now, there are three archaeological sites with published faunal remains: Montinhos 6, Alto do Brinches 3 and Torre Velha 12 (Table 3). Despite this limited number, important information can be extracted from these publications. First, we notice the complete absence of equids and consequently the loss of importance of the hunting of large game. Secondly, domestic capridae are the most important taxon, demonstrating that herding is the most important economic activity. Moreover, suids lose their importance and bovids are residual.

However, cattle are the most important specie within funerary contexts: they appear in $77 \%(n=21)$ of the burials connected with the 2nd millennium BC (Table 4). Domestic caprids are associated with $17 \%(n=5)$ of the burials, and, at the end of the list, there is a single burial with a complete skeleton of Sus sp. and another 
Table 2. Species associated with Chalcolithic funerary contexts.

\begin{tabular}{|l|l|l|l|}
\hline Site & Type & Species & References \\
\hline H. St. Margarida & Dolmen & Canis familiaris & Moreno Garcia 2003 \\
\hline Perdigões & Tholos 1 e 2 & $\begin{array}{l}\text { Cervus elaphus, Bos taurus, Ovis/Capra, Lagomorpha, Vulpes vulpes, } \\
\text { Sus sp., Equus sp., Birds }\end{array}$ & Cabaço 2009 \\
\hline Monte das Covas 3 & Pits & Canis sp. & Valera and Costa 2013 \\
\hline Monte do Cardim 6 & Tholos & Ovis/Capra & Valera and Costa 2013 \\
\hline R. S. Domingos 1 & Pits & Carnivore (probably Canis sp.) & Valera and Costa 2013 \\
\hline Monte da Guarita 2 & Tholos & Lagomorpha, Cervus elaphus, Equus sp. & Unpublished \\
\hline Bela Vista 4 & Hypogeum & Carnivore (probably Canis sp.) & Valera and Costa 2013 \\
\hline
\end{tabular}

Table 3. Mammal frequencies in the Middle Bronze Age dwelling contexts.

\begin{tabular}{|l|c|c|c|c|c|l|l|}
\hline & $\begin{array}{c}\text { Equus } \\
\text { sp. }\end{array}$ & $\begin{array}{c}\text { Sus } \\
\text { sp. }\end{array}$ & $\begin{array}{c}\text { Cervus } \\
\text { elaphus }\end{array}$ & $\begin{array}{c}\text { Bos } \\
\text { sp. }\end{array}$ & $\begin{array}{c}\text { Ovis/ } \\
\text { Capra }\end{array}$ & Leporidae & References \\
\hline Montinhos 6 & $0 \%$ & $4 \%$ & $1.50 \%$ & $6 \%$ & $34 \%$ & $54 \%$ & Costa 2013 \\
\hline Alto de Brinches 3 & $0 \%$ & $91 \% *$ & $2 \%$ & & $3 \%$ & $0 \%$ & Delicado et al. 2017 \\
\hline Torre Velha 12 & $0 \%$ & $7 \%$ & $2 \%$ & $9 \%$ & $29 \%$ & $40 \%$ & $\begin{array}{l}\text { Senra 2018 } \\
\text { Senra et al. 2019 }\end{array}$ \\
\hline
\end{tabular}

* One complete skeleton.

Table 4. Middle Bronze Age mammals in funerary contexts.

\begin{tabular}{|c|c|c|c|c|c|}
\hline Site & Sus sp. & Bos taurus & Ovis/Capra & O. cuniculus & References \\
\hline Torre Velha 3 & & 9 & 1 & 0 & Alves et al. 2010 \\
\hline $\begin{array}{l}\text { Montinhos } 6 \\
\text { (hypogea) }\end{array}$ & & 3 & 3 & 1 & Costa and Baptista 2014 \\
\hline $\begin{array}{l}\text { Montinhos } 6 \text { (pit } \\
\text { FE152) }\end{array}$ & & & 1 & & Costa et al. in preparation \\
\hline Torre Velha 12 & & 2 & 0 & 0 & Costa et al. 2019 \\
\hline Outeiro Alto 2 & & 5 & 0 & 0 & Filipe et al. 2013 \\
\hline H. Belmeque & & 2 & 0 & 0 & Soares 1994 \\
\hline H. Jacinto & 1 & 0 & 0 & 0 & Baptista et al. 2013 \\
\hline Total & $1(3 \%)$ & $21(77 \%)$ & $5(17 \%)$ & $1(3 \%)$ & \\
\hline
\end{tabular}
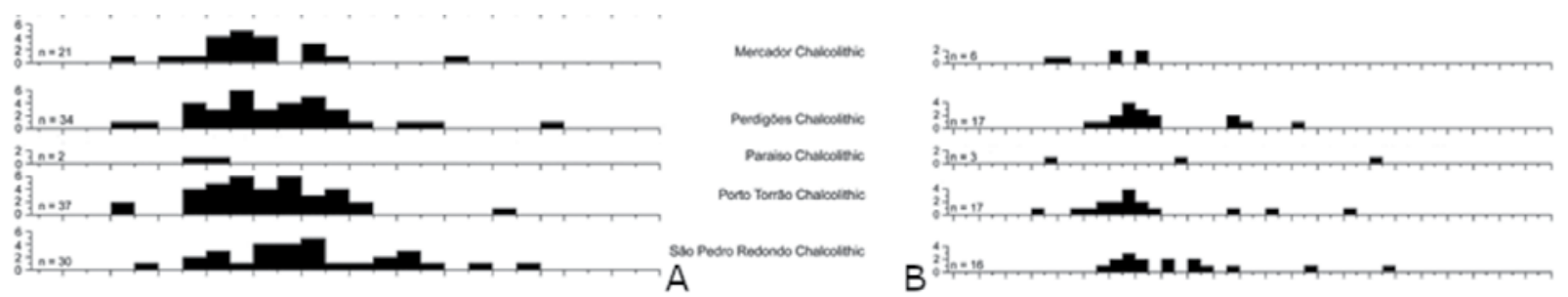

Figure 2. Sus sp. measurements published in Davis et al. 2018 (adapted from figure 22, p. 124). A - measurements on humerus; B - measurements on tibia. 
association with rabbit. Cattle is represented solely from front limbs, whether articulated radius, ulna and carpals or isolated carpals (Costa et al. 2019). As for Ovis/Capra, isolated bones, such as radius or carpals, were collected inside hypogea, and in one pit (FE152) at Montinhos 6 there was a cluster of limb bones, cranium and torso. For suid and rabbit, complete or nearly complete skeletons were found.

\section{Discussion}

Data reveals that suids were very important for 3rdmillennium $\mathrm{BC}$ communities, mainly for the ones that occupy ditched enclosures, such as Perdigões, Porto Torrão, or Montoito 2. Even in those sites where suids are not the most numerous, their frequency is still high, as shown by the 3rd-millennium BC contexts of Alto do Brinches 3 and Torre Velha 12, and Porto das Carretas. On the other hand, canids are the most frequent taxon in 3rd-millennium BC funerary contexts, appearing in four of the seven sites listed in this chapter.

Domestic and wild animals are difficult to distinguish in Iberian suids (Albarella et al. 2005). Only osteometric differences of some anatomical elements can help us detect the eventual occurrence of both wild and domestic suids in a given assemblage. Davis et al. (2018) have recently published data on the osteometry of suids from several sites in southern Portugal. The results are shown in Figure 2. Measurements taken from distal humerus and tibia demonstrates the presence (Mercador, Perdigões, São Pedro, Porto Torrão, Paraiso) of both boar and pig (represented by the extremities of the distribution in the graphs). However, there is a large quantity of measurements in between both extremities, demonstrating that most measurements cannot be assigned with certainty to either boar or pig. This variation in Sus sp. size can be explained through behaviour - as boar and pig are prone to crossbreed (Hadjikoumis 2012).

Preferences for suids in the 3rd millennium BC are difficult to interpret, since they only provide meat and raw materials (skin, bones and teeth). Nevertheless, they have high fertility rates, having on average six piglets twice a year; in addition, they are well adapted to rough landscape and oak forests, where they feed on acorns (Hadjikoumis 2012).

As for the other taxa, data shows that, in the 2nd millennium $\mathrm{BC}$, equids completely disappear; none of the faunal assemblages from this period has evidence of equids, while in the $3 \mathrm{rd}$ millennium they are abundant (Table 1).

Red deer show up with high percentages in the 3 rd millennium BC, e.g. at Montoito 2, Mercador and S. Pedro it is the second-best species represented.
Leporidae, both hare and rabbit, are also very common. Hunting large game is thus a very important activity for communities of the 3rd millennium BC, but not so for middle 2nd-millennium BC communities. At Alto de Brinches 3 and Montinhos 6, the red deer remains are fragments of stem, which could have been collected after the annual stem loss, and do not mean that the animal was hunted necessarily. For communities in the middle of the 2nd millennium $\mathrm{BC}$, small game hunting (hare and rabbit) is more important than hunting larger animals, as reflected in the percentages of leporids in the living contexts of Montinhos 6 and Torre Velha 12.

Domestic caprids are important animals for 3rd- and 2nd-millennium BC communities, where their remains are very frequently observed. In the 2nd millennium $\mathrm{BC}$, however, cattle are the species with the highest symbolic value, it being the taxon more often associated with funerary rituals (Table 4). Caprids, suids, and rabbit also appear associated with funerary practices, but in smaller numbers.

Considering the available data, it is plausible that, following the changes in social dynamics that happened at the end of the $3 \mathrm{rd}$ millennium $\mathrm{BC}$, differences regarding animal exploitation and symbolism also occurred.

At the end of 3rd millennium BC there were several changes in the environment as a result of the $4.2 \mathrm{ky}$ BP climatic event. These changes can be summed up by the aridity manifested with the decline of the Mediterranean forest (Ramos-Róman et al. 2018). In the southwest of the Iberian Peninsula these changes were the decreasing trend in deciduous Quercus (oak) and Pinus pinea (stone pine), and the increase in dry-adapted thermophilus trees and shrubs, e.g. Quercus ilex (holm oak) and Olea europaea (olive) (Blanco-González et al. 2018). These climatic changes may mean changes in the number of suids, especially the decrease of individuals.

The lack of radiocarbon dating for the Bronze Age makes it difficult to assume that changes in animal representativeness is directly related to environmental changes. It is assumed by researchers that in the last quarter of the 3rd millennium BC, in Southern Portugal, 3rd-millennium BC cultural dynamics (as evidenced by its architectural, material and anthropological expressions) came to an end (e.g. Valera 2014; 2015; Blanco-Gonzalez et al. 2018). The changes in funerary contexts, where collective secondary burials are replaced by individual primary burials, is accompanied by the introduction of a highly standardised behaviour of adding to the grave the front-limb segments or isolated bones of cattle or caprids (Costa et al. 2019). As to the non-funerary contexts, the end of ditched and walled enclosures, where suids play an important role in subsistence and symbolism, is replaced by 
domestic caprines, a social species closer to the human communities.

\section{Conclusion}

This contribution has reviewed data of faunal remains, both in funerary and non-funerary contexts, with the objective of understanding changes in human/animal interactions in the transition from the 3rd to the 2nd millennium $B C$. Regarding dwelling contexts, we notice that in the 3rd millennium $\mathrm{BC}$ suids are the most important taxon exploited, namely in the enclosures (both ditched and walled). Suid behaviour is strongly marked by crossbreeding, making it difficult to assume if the suid remains found correspond to wild or domestic species. Nevertheless, suids are solitary animals that naturally avoid human contact but are adapted to oak forests and rugged landscapes; omnivorous animals, they can find food for themselves, dispensing with the need for humans to provide for them.

The hunting of larger game was still a very important activity to those 3rd-millennium BC communities, as attested by the numerical importance of red deer, and, to a less extent, horse; leporidae (rabbit and hare) were also exploited.

The available data suggest that in the 2nd millennium BC suids were replaced by domestic caprines as the most important taxon. The data also indicate that hunting larger animals was completely abandoned, and only lagomorphs remain as prey.

Regarding funerary practices, the importance of canids and random anatomical representations of other species, is replaced by a highly standardised practice where front-limb segments, or front-limb bones, of cattle or caprines are used.

More in-depth research is needed to understand why, how, and exactly when these changes occurred. For now, the available data suggest that in the 2nd millennium $B C$ a new paradigm emerged - in both symbolic and functional terms - of exploiting more social and human dependent animals, such as caprines and cattle.

\section{Acknowledgements}

This work was funded by the Portuguese Science and Technology Foundation (FCT - Fundação para a Ciência e a Tecnologia), under a work contract provided by numbers 4, 5 and 6 of article 23ㅇ of D.L. n. 57/2016, August 29th, amended by law n. 57/2017 July 19th.

Acknowledgements to Hugo Oliveira for reviewing the English language and to Célia Gonçalves for Figure 1.

\section{References}

Albarella, U., Davis, S.J.M., Detry, C. and Rowley-Conwy, P. 2005. Pigs of the 'Far West': the biometry of Sus from archaeological sites in Portugal. Anthropozoologica 29.

Alves, C., Costeira, C., Estrela, S., Porfírio, E., Serra, M., Soares, A.M.M. and Moreno-García, M. 2010. Hipogeos funerarios del Bronce Pleno en Torre Velha 3 (Serpa, Portugal). i¿El Sureste en el Suroeste?! Zephyrvs 21: 133-153.

Alves, C., Estrela, S., Porfírio, E. and Serra. M. 2014a. Intervenção arqueológica no sítio de Alto de Brinches 3 (Reservatório Serpa - Norte): Resultados Preliminares, in $4^{\circ}$ Colóquio de Arqueologia do Alqueva: o Plano de Rega (2002-2010). Memórias d' Odiana $2^{\mathrm{a}}$ série: 96-102 Beja: EDIA.

Alves, C., Estrela, S., Costeira, C., Porfírio, E., Serra, M., Soares, A.M. and Moreno-García, M. 2014b. Caracterização preliminar da ocupação préhistórica da Torre Velha 3. (Barragem da Laje Serpa, in Actas do $4^{\circ}$ Colóquio de Arqueologia do Alqueva O Plano de Rega (2002 2010), 24 a 26 de Fevereiro de 2010: 103-111. Beja: EDIA.

Antunes, M.T.1987. O povoado fortificado calcolítico do Monte da Tumba IV: mamíferos (nota preliminar). Setúbal Arqueológica Setúbal VIII: 103-144.

Arnaud,J.M. 1993. O povoado calcolítico de Porto Torrão (Ferreira do Alentejo): síntese das investigações realizadas. Vipasca 2: 41-60.

Baptista, L., Gomes, S. and Costa, C. 2012b. As dinâmicas de deposição e construção no sítio pré-histórico de Horta de Jacinto (Beringel, Beja), in M. Deus (ed.) Actas do V Encontro de Arqueologia do Sudoeste Peninsular, Almodôvar, 18, 19 e 20 Novembro, 2010: 585596. Almodôvar: Câmara Municipal de Almodôvar.

Baptista, L., Pinheiro, R. and Rodrigues, Z. 2012a. Espacialidades dos cadáveres em Montinhos 6: contributo para a compreensão das práticas funerárias da Idade do Bronze do Sudoeste Peninsular, in M. Deus (ed.) Actas do V Encontro de Arqueologia do Sudoeste Peninsular, Novembro 2010: 149170. Almodôvar: Câmara Municipal de Almôdovar.

Blanco-González, A., Lillios, K.T., López-Sáez, J.A. and Drake, B.L. 2018. Cultural, Demographic and Environmental Dynamics of the Copper and Early Bronze Age in Iberia (3300-1500 BC): Towards an Interregional Multiproxy Comparison at the Time of the 4.2 ky BP Event. Journal of World Prehistory 31: 1-79 (https://doi.org/10.1007/s10963-018-9113-3).

Cabaço, N. 2012. Restos faunísticos em contexto funerário nos Perdigões, Reguengos de Monsaraz (Sepulcros 1 e 2), in J. Cascalheira and C. Gonçalves (eds) Actas das IV Jornadas de Jovens em Investigação Arqueológica -JIA2011. Vol I.Promontoria Monográfica 16: 259-267. Faro: Núcleo de Arqueologia e Paleoecologia Departamento de Artes e Humanidades Faculdade 
de Ciências Humanas e Sociais (Universidade do Algarve).

Cardoso, J.L. 2013. Anexo 3 A fauna do povoado Calcolítico do Porto das Carretas, in J. Soares (ed.) Transformações sociais durante o III milénio AC no Sul de Portugal. o povoado do Porto das Carretas, Memórias d'Odiana $2^{\underline{a}}$ série Estudos Arqueológicos do Alqueva 5: 501-505. Beja: EDIA.

Costa, C. 2006. Anexo V-Análise preliminar da fauna, in A.F.C. Rodrigues Casa Branca 7: Um povoado na transição do $4^{\circ}$ para o $3^{\circ}$ milénio a.n.e. na margem esquerda do Guadiana (Serpa). Unpublished Master's dissertation, University of Lisbon.

Costa, C. 2010. Os restos faunísticos de animais vertebrados do sector I dos Perdigões (Fossos 3 e 4 e Fossas). Apontamentos de Arqueologia e Património 6: 53-74.

Costa, C. 2013. Tafonomia em contexto pré-histórico. A zooarqueologia como recurso para a compreensão das 'estruturas em negativo' da pré-história recente. Unpublished PhD thesis, University of the Algarve.

Costa, C. and Baptista, L. 2014. The inclusion of faunal remains in Bronze Age funerary practices in Southern Portugal. Montinhos 6 as a case study, in C. Detry and R. Dias (eds) Proceedings of the First Zooarchaeology Conference in Portugal, Held at the Faculty of Letters, University of Lisbon, 8th-9th March 2012: 33-46. British Archaeological Reports International Series 2662. Oxford: Archaeopress. Costa, C., Baptista, L., Gomes, S., Rodrigues, Z. (in preparation). Sheep/goat and hare at the funerary rituals of Bronze Age: the case of interments in Montinhos 6 (Southern Portugal).

Costa, C., Bettencourt, A.M.S. and Senra, M. 2019. The symbolic meaning of cattle and sheep/goat in the Bronze Age: Faunal inclusions in funerary contexts of South-Western Iberia. International Journal of Osteoarchaeology (https://doi.org/10.1002/oa.2756).

Costa, C. and Mataloto, R. 2017. Contributos para o conhecimento da componente animal dos recintos de fossos calcolíticos. A fauna vertebrada de Montoito 2, in J.M. Arnaud and A. Martins (eds) Arqueologia em Portugal / 2017 - Estado da Questão: 741-751. Lisboa: Associação dos Arqueólogos Portugueses.

Davis, S.J.M., Gabriel, S. and Simões, T. 2018. Animal remains from Neolithic Lameiras, Sintra: the earliest domesticated sheep, goat, cattle and pigs in Portugal and some notes on their evolution. Archaeofauna 27: 93-172 (https://doi.org/10.15366/ archaeofauna2018.27.006).

Davis, S. and Mataloto, R. 2012 Animal remains from Chalcolithic São Pedro (Redondo, Alentejo): evidence for a crisis in the Mesolithic. Revista Portuguesa de Arqueologia 15: 47-85.

Delicado, D., Santos, A. B., Porfírio, E., Serra, M. and Detry, C. 2017. Alto de Brinches 3 (Serpa): estudo da fauna recuperada nos contextos do $3^{\circ}$ e $2^{\circ}$ milénios a.n.e. Cadernos Do GEEVH 6(1): 1-28.

Filipe, V., Godinho, R., Granja, R., Ribeiro, A. and Valera, A. 2013. Espacios funerarios de la Edad del Bronce en Outeiro Alto 2 (Brinches, Serpa, Portugal): la necrópolis de hipogeos. Zephyrvs LXXI: 107-129.

Gomes, S., Baptista, L. and Rodrigues, Z. 2013. Tradições de inumação durante a Idade do Bronze em Torre Velha 12 (Salvador, Serpa), in J.J. Avila, M. Bustamante-Álvarez and M. García Cabezas (eds) Actas del VI Encuentro de Arqueología del Suroeste Peninsular: 709-732. Villafranca de los Barros: Ayuntamiento de Villafranca de los Barros.

Gonçalves, V. 2003. STAM3 A anta 3 da Herdade de Santa Margarida (Reguengos de Monsaraz). Trabalhos de Arqueologia 32. Lisboa: Instituto Português de Arqueologia.

Hadjikoumis, A. 2012. Traditional pig herding practices in southwest Iberia: Questions of scale and zooarchaeological implications. Journal of Anthropological Archaeology 31: 353-364 (https://doi. org/10.1016/j.jaa.2012.02.002).

Lago, M., Duarte, C., Valera, A., Albergaria, J., Almeida, F. and Carvalho, A.F. 1998. Povoado dos Perdigões (Reguengos de Monsaraz): dados preliminares dos trabalhos arqueológicos realizados em 1997. Revista Portuguesa de Arqueologia 1(1): 45-152.

Mataloto, R. and Costeira, C. 2008. O povoado Calcolítico do Paraiso. Revista Portuguesa de Arqueologia 11(2): 5-27.

Mataloto, R., Costeira, C., Davis, S., Clemente, R. and Santos, I. 2012. Os povoados de fossos do Paraíso: Uma ocupação do III/IVo milénio a. C.na região de Elva. Balanço das intervenções 2009-2010, in M. Deus (ed.) Actas do V Encontro de Arqueologia do Sudoeste Peninsular Almodôvar 18 a 20 de Novembro de 2010: 3972. Almodôvar: Câmara Municipal de Almodôvar.

Mataloto, R., Estrela, S. and Alves, C. 2007. As fortificações calcolíticas de São Pedro (Redondo, Alentejo Central, Portugal), in E. Cerrillo, and J. Valadés (eds) Los primeros campesinos de La Raya: Aportaciones recientes al conocimiento del neolitico y calcolítico en Extremadura y Alentejo. Actas de las Jornadas de Arqueología del Museu de Cáceres 1. Memorias 6: 113-141. Cáceres: Consejería de Cultura y Turismo.

Moreno Garcia M. 2013. Estudo arqueozoológico dos restos faunísticos do povoado calcolítico do Mercador (Mourão), in A.C. Valera (ed) As sociedades agropastoris na margem esquerda do Guadiana ( $2^{\underline{a}}$ metade do IV e inícios do II milénio AC), Memórias d'Odiana, $2^{\text {a }}$ série: 321-349. Beja: EDIA.

Pereira, V. 2016. Repastos alentejanos: dados preliminares da fauna de Porto Torrão (Ferreira do Alentejo), in R. Vilaça and M. Serra (eds) Matar a fome, alimentar a alma, criar sociabilidades. Alimentação e comensalidade nas sociedades pré e proto-históricas: 39-53. Coimbra: Instituto de Arqueologia, Secção de 
Arqueologia, FLUC, Centro de Estudos Pré-Históricos da Beira Alta, CEPBA, Palimpsesto, Estudo e Preservação do Património Cultural Lda.

Ramos-Román, M.J., Jiménez-Moreno, G., Camuera, J., García-Alix, A., Anderson, R.S., Jiménez-Espejo, F.J. and Carrión, J.S. 2018. Holocene climate aridification trend and human impact interrupted by millennialand centennial-scale climate fluctuations from a new sedimentary record from Padul (Sierra Nevada, southern Iberian Peninsula). Climate of the Past 14: 117-137 (https://doi.org/10.5194/cp-14-117-2018).

Rodrigues, A.F.C. 2006. Casa Branca 7: Um povoado na transição do $4^{0}$ para o $3^{0}$ milénio a.n.e. na margem esquerda do Guadiana (Serpa). Unpublished Master's dissertation, University of Lisbon.

Senra, M.C.C. 2018. Estudos dos materiais faunísticos do $3^{\circ}$ e $2^{\circ}$ milénios a.C. de Torre Velha 12 (Serpa, Beja, SW de Portugal). Unpublished Master's dissertation, University of Minho.

Senra, M., Costa, C., Bettencourt, A.M.S., Baptista, L. and Gomes, S. 2019. Faunal remains from Torre Velha 12 (Serpa, Beja, Southwest of Portugal): Relationship between animals and Bronze Age communities. Heritage 2: 216-229 (https://doi.org/10.3390/ heritage2010016).

Sherratt, A. 1981. Plough and pastoralism: aspects of the secondary products revolution in I. Hodder, G. Isaac, $\&$ N. Hammond (eds.) Pattern of the Past: Studies in Honour of David Clarke,

Silva, C.T. and Soares, J. 1987. O povoado fortificado calcolítico do Monte da Tumba. I - Escavações arqueológicas de 1982-86 (Resultados preliminares). Setúbal Arqueológica 8: 29-79.

Soares, A.M.M. 1994. O Bronze do Sudoeste na Margem Esquerda do Guadiana. As Necrópoles do Concelho de Serpa. Actas das V Jornadas Arqueológicas (Lisboa, 1993): 179-197. Lisboa: Associação dos Arqueólogos Portugueses.
Soares, J. 2013. Transformações sociais durante o III milénio AC no Sul de Portugal. O povoado do Porto das Carretas. Memórias d'Odiana $2^{\mathrm{a}}$ série. Estudos Arqueológicos do Alqueva 5. Beja: EDIA.

Valera, A.C. 2013. As sociedades agropastoris na margem esquerda do Guadiana ( $2^{g}$ metade do IV e inícios do II milénio AC). Memórias d'Odiana $2^{\mathrm{a}}$ série. Beja: EDIA.

Valera, A.C. 2014. Continuidades e descontinuidades entre o $3^{\circ} \mathrm{e}$ a primeira metade do $2^{\circ}$ milénio a.n.e. no Sul de Portugal: alguns apontamentos em tempos de acelerada mudança, in S. S. Lopes (ed.) A Idade do Bronze em Portugal: os dados e os problemas, Antrope: 287-317. Tomar: Centro de Pré-História.

Valera, A.C. 2015. Social change in the late 3rd millennium $\mathrm{BC}$ in Portugal: The twilight of enclosures, Mitteldeutscher Archäologentag, n.d. 2200 $B C$ - ein Klimasturz als Ursache für den Zerfall der alten Welt? 7. Mitteldeutscher Archäologentag vom 23. bis 26. Oktober 2014 in Halle (Saale): 409-427. Halle: Tagungen des Landesmuseums für Vorgeschichte.

Valera, A., Becker, H. and Costa, C. 2014. Os recintos de fossos pré-históricos de Monte da Contenda (Arronches) e Montoito 2 (Redondo). Estudos Arqueológicos de Oeiras 21: 355-377.

Valera, A.C. and Costa, C., 2013. Animal limbs in funerary contexts in southern Portugal and the question of segmentation. Anthropozoologica 48: 263275 (https://doi.org/10.5252/az2013n2a5).

Valera, A.C., Figueiredo, M., Lourenço, M., Evangelista, L.S., Basílio, A.C. and Wood, R. (eds) 2019. O Tholos de Cardim 6. Porto Torrão, Ferreira do Alentejo (Beja). Lisboa: Núcleo de Investigação Arqueológica.

Valera, A.C., Lago, M., Duarte, C. and Evangelista, L.S. 2000. Ambientes funerários no complexo arqueológico dos Perdigões - uma análise preliminar no contexto das práticas funerárias calcolíticas no Alentejo. ERA-Arqueologia 2: 84-105. 


\title{
Chapter 9
}

\section{Situated Knowledge and Early Bronze Age Occupation at Must Farm, Cambridgeshire}

\author{
Lesley McFadyen \\ Birkbeck, University of London \\ l.mcfadyen@bbk.ac.uk
}

\begin{abstract}
One might describe in broad brushstrokes a difference between Late Neolithic (3000-2500 cal BC) and Early Bronze Age (2500-1500 cal BC) worlds in Britain: the Late Neolithic would include the insular pottery type, Grooved Ware, and its association with complex feasting events at henges and timber/stone circle monument complexes such as Avebury and Stonehenge; the Early Bronze Age would be defined by the appearance of Beaker pottery from the Continent, as well as the inclusion of these pots in single graves, so announcing a marked change in funerary practice. However, were one to choose a finer brush, there is a chance to construct a different and much more intricate canvas. On a low-lying gravel terrace overlooking a floodplain on the western edge of the English fens, a Middle Bronze Age peat horizon obscures an old land surface dotted with small pits of Late Neolithic and Early Bronze Age date. This tenure to occupation requires situated knowledge; dramatic change, new arrivals, are not a part of this picture. To understand this, I take a landscape-approach to the archaeological evidence and remark on continuity, rather than making chronological division. I explore how landscapes are configured through time depth as well as spatial surface, how they are known, arguing that periodisation cannot be the basis for our question making processes in archaeology. Otherwise, we will never escape from the narrative device of event and change.
\end{abstract}

Key words: Chronology, change, spatial surface, landscape, tenure, time depth, situated knowledge.

In an assemblage approach, a Beaker does not have the same effect, and is not understood in the same way, in the south of France as in the north of Scotland, nor does it have the same effect at $2000 \mathrm{BC}$ as it does at $2100 \mathrm{BC}$ or $2020 \mathrm{AD}$.'

(Crellin 2020: 166)

\section{Introduction}

I could describe in broad brushstrokes a difference between Late Neolithic (3000-2500 cal BC) and Early Bronze Age (2500-1500 cal BC) worlds in Britain. A characterisation of the Late Neolithic would include the insular pottery type, Grooved Ware (Cleal and MacSween 1999), and its association with complex feasting events at henges and timber/stone circle monument complexes such as Durrington Walls (Gibson 1998; Ray and Thomas 2018). Meantime, the beginning of the Early Bronze Age would be defined by the appearance of Beaker pottery from the Continent (and interaction within the North Sea/Channel) (Wilkin and Vander Linden 2015), and the inclusion of these pots in single graves, so announcing a significant change in funerary practice. Whilst stable isotope analysis, and studies of ancient DNA on the bodies of the dead buried in the single graves, bring human mobility from Continental Europe into the picture (Parker Pearson et al. 2019a; Olalde et al. 2018). However, if I choose a finer brush, and describe lines of movement and the temporality of occupation that is absent in the previous depiction, there is a chance to construct a different and much more intricate canvas.
On low-lying gravel terraces overlooking a floodplain on the western edge of the English fens, a Middle Bronze Age peat horizon obscures an old land surface dotted with small pits of Late Neolithic and Early Bronze Age date. Seven seasons of fieldwork at Must Farm, Cambridgeshire have test-pitted the buried soil to get at the density and distribution of material culture at a landscape-scale. The results of these findings are the lines of movement. What is remarkable, is that although the material culture is different, there are connections in the nature of occupation practices. Perhaps, more importantly, there is duration to, and a tenacity for, a subtle and nuanced knowledge of that landscape. This kind of occupation points to situated knowledge, that is enabling practices which saw opportunity in the particular (Haraway 1991). Dramatic change, new arrivals, are not the focal point of this picture.

I take a landscape-approach to the archaeological evidence and remark on connections and duration in the nature of occupation practices, rather than making a chronological division. I look at how a landscape is occupied through tasks, the movement and duration that those tasks carry with them, the temporal grain of landscape evidenced in how people know it, and 
their ongoing tenacity to stay in it. I explore how landscapes are configured through time depth as well as spatial surface, how they are understood. I argue that periodisation cannot be the basis for our question making processes in archaeology, otherwise we will never escape the narrative device of event and change. Similarly, our archaeological accounts need to move away from the construction of polarised arguments for either change or continuity. Instead, I consider overlapping forms of interaction and how they are constituted. I argue that it is through the process of their emergence, through occupation practices, that a nuanced image of change takes form.

\section{Chronology}

The prehistory of Britain has been conceptualised by waves of different interpretive ideas, which on the surface seem to have come and gone, but actually have left a deep legacy to the narratives we write. Key to a cultural historical approach was the idea that things were a measure of people (based on typology, social evolution and stratigraphy), and prehistory was constructed as a series of events with a focus on change, and change was accounted for by the migration of people (Childe 1930). More recently, a national-scale radiocarbon dating programme was built into the Beaker People Project and its study of Beaker-associated human remains and their grave goods (Parker Pearson et al. 2019a), and the large-scale excavations of the Stonehenge Riverside Project with its focus on the landscape contexts of monuments (Parker Pearson et al. 2019b). Strontium and oxygen isotope analysis of human and cow, their bone and teeth (Parker Pearson et al. 2019a), studies of ancient DNA (Olalde et al. 2018), absolute dates reduced down to generational time through Bayesian modelling, were all embedded in a 'social archaeological' approach (Parker Pearson 2012). Archaeological narratives may now be constructed through human agency, but they still have their focus on change, albeit with more detail on the when and where, they are again about human mobility - Beaker People. As I write this chapter, a new exhibition has just opened at the site of Stonehenge, Making Connections: Stonehenge in its Prehistoric World. English Heritage give the following as context:

In the late Neolithic, when Stonehenge was built, communities living in the British Isles appear to have been relatively insular. Although people were travelling widely and exchanging ideas from Orkney to Southern England, there was little or no communication with Europe. By contrast, in the early Neolithic and early Bronze Age, mass migrations of people, including the first farmers and earliest metal-workers, arrived. During these times, objects, styles and religious beliefs were being shared widely with Europe. Recent DNA analysis indicates that the Beaker culture communities who brought Bronze Age technology to the British Isles 4500 years ago, were part of a migration that almost completely replaced the communities of the British Isles in the course of a few centuries.

A recurring focus on change, and an order of study from a new (Early Bronze Age) to an old (Late Neolithic) event, and so earlier contexts are always set as the background for the something else (see Crellin 2020 and her critique of a block-time approach to change). Cleal and Pollard (2012) have argued instead for the 'long view' as understood in the context of a series of changes and developments with their origins in the preceding centuries, and which continue into the 'full Early Bronze Age' (2012: 317). Rather than 'difference' or 'event', they explore contemporaneous time and shared landscapes (i.e. settings that involve Grooved Ware and Beaker). Their strategy is to look back at the full biography of the unified complex of Avebury, Wiltshire, and how it emerged.

For example, the Early Neolithic causewayed enclosure at Windmill Hill, and the Horslip and South Street long barrows, were also key reference points in the Late Neolithic. In the Late Neolithic, these sites became part of a formally connected built landscape that extended from the Longstones enclosure through to the Beckhampton avenue to the Avebury henge. Similarly, the Early Neolithic West Kennet long barrow was a key reference point to the later West Kennet palisade enclosures and the start of Silbury Hill, through to the West Kennet avenue and then to the Avebury henge. Cleal and Pollard demonstrate (see also Gibson 1982) that these Early Neolithic sites were key places for practices that involved Grooved Ware and Beaker pottery; both types of pottery are contained in the upper fills of the South Street long barrow ditch and that of the outer circuit of the Windmill Hill causewayed enclosure, and the deposition of both is in the backfill of Horslip and West Kennet long barrow. Whilst the West Kennet 'occupation site', where a standing stone was missed out in the construction of the avenue, is a midden spread that includes Grooved Ware, ${ }^{1}$ and the only point in the landscape where there is a Beaker-associated inhumation. A much older past is referenced in practices that involve Grooved Ware and Beaker pottery (Cleal and Pollard 2012: 325). The formalisation of movement though the landscape on architectural terms is shared in the Late Neolithic and the Early Bronze Age, there is a connection (in time and in space). Similarly, in the Stonehenge landscape, there is a shared reference to the past. For example, where the ditched avenue met the ring of 56 Aubrey Holes that contained deposits of cremated bone and Grooved

${ }^{1}$ It should be noted that the majority of the artefactual evidence is Middle Neolithic in date. 


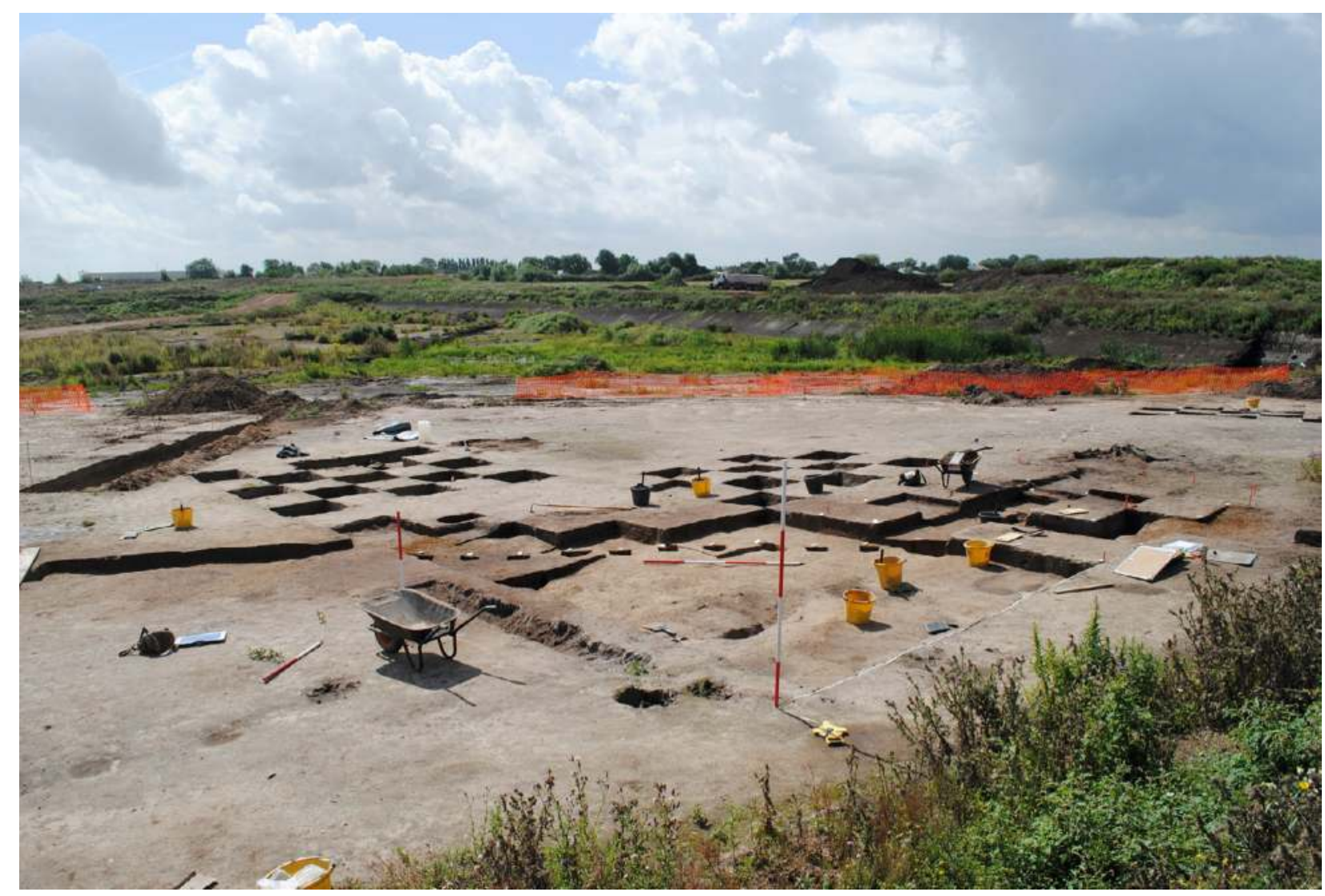

Figure 1

Ware pottery, this is where the Beaker 'archer' was buried. Pits that cut through major postholes from the Southern Circle of Durrington Walls and at Woodhenge, contained Grooved Ware and Beaker. Cleal and Pollard argue that these are equal strategies of marking and memorialisation (2012: 327). This textured landscape, with a more nuanced temporal grain, creates a different kind of picture. However, the key requisite of this shared landscape is contemporaneous time, there are no gaps.

\section{Landscape}

What happens if we continue with the temporal grain of landscape, but switch to focus more on the everyday and movement through occupation of that landscape. For seven successive summer seasons, Birkbeck and the Cambridge Archaeological Unit have been running a field school and small-scale research project for Birkbeck students that explores the deeply buried landscape of the lower Nene Valley and the Flag Fen Basin. Based at Must Farm Quarry, Whittlesey, Cambridgeshire, the project comprises the exploration of the prehistoric sub-fen land-surface, in particular a dry woodland landscape at scale (see Figure 1). This was a lime-oak woodland with substantial inroads through it beginning in the Late Neolithic (French, in press). Incidentally, there are Late Neolithic (henge and oval barrows) and Early Bronze Age (round barrow) monuments in this landscape, too. Test pitting of the buried soil, and excavation of associated features, at Must Farm has helped define a parallel landscape: comprising a linear zone of concentrated Late Neolithic flint working and pit clusters overlooking the floodplain of the Neolithic Nene, with Early Bronze Age burnt mounds located below this zone, and above it Early Bronze Age pit clusters, midden spreads and roundhouses. Furthermore, by the Early Bronze Age there were extensive estuarine mudflats of the Early Bronze Age Nene. This was a changing landscape that saw an ostensibly terrestrial space partially inundated by the sea.

So a low-lying terrace overlooking a floodplain which became estuarine at the beginning of the Bronze Age (c. $2400 \mathrm{BC}$ ). The buried soil that survived on the lowlying terrace contained a mixed assemblage (mostly lithics) indicative of Neolithic activity. The buried soil was disturbed by ploughing post-Beaker period, and as such it masked pit features of Late Neolithic and Early Bronze Age date. The pit features either contained Grooved Ware pottery or Beaker pottery, but these were never together. There is no evidence for contemporaneous time as Cleal and Pollard have argued (2012), instead there is a vertical fracture on temporal terms. However, there is some sense of zoning to each of these taskscapes, through very similar kinds 
of practice. There were similar activities occurring in the same space but at different (successive) times. Due to similar kinds of occupation practices, my argument centres on the duration of time that is required to know how to live in such a landscape.

Immediately southwest of a Middle Neolithic monument (associated with Peterborough Ware pottery) (Block C,E,F,G,H, Figure 2), the buried soil revealed a textured landscape busy with Early-Middle Neolithic occupation. Further south (Block O, Figure 2), we discovered Late Neolithic activity. We excavated a group of eight small and medium-sized pits containing charcoal-rich fills and burnt stones. These were cooking pits and rubbish pits, associated with Grooved Ware pottery (Figure 3). In Block 7, a further three Late Neolithic pits were excavated, again with charcoal-rich fills and burnt stones (Figure 2). And in Row 1 (Figure 2), two further cooking pits were excavated, this time associated with the knapping of curated polished stone axes. From the worked flint from these pit assemblages, there is some evidence for knapping flint, and the large blade flakes were used for a number of other tasks. These pit clusters created settings for small groups to carry out multiple tasks (cutting, carpentry and butchery) whilst also preparing, cooking and eating food. There is a short duration between the carrying out of task activities and the deposition of things in pits. There is a sense of mobility, though with domestic animals - pastoralism. Hunting is also important, many transverse arrowheads have been recovered as single finds in the buried soil on the lower gravel terrace, and alongside cattle there is a wild element to the faunal assemblage, e.g. auroch. The distance between the groups of pits ranges from 20-50 $\mathrm{m}$, but each group consists of a small number of pits. These are small-scale social arenas of action (Figure 4). However, if we look at the density and distribution of material culture from the test-pit sampling (Figure 5), we see that there is a larger-scale linear zone of action through the landscape, roughly east to west, following the contour of the gravel terrace. The density of artefacts increases in each of the areas of the pit clusters. Similarly there is a zone of activity much lower down the contour, in what would have been the lower terrace, nearer the river channel; although the finds are sparse in comparison, and this was where the arrowheads were located. All of the test-pit finds in these two zones are Neolithic, albeit from across the Neolithic period.

Southeast of the Late Neolithic pits from Block 7, on the slope of the terrace edge, we encountered a burnt mound (F879, Figure 2). It constituted a wide but thin spread of fire-cracked stones in a dark, charcoal-rich matrix (length $3.9 \mathrm{~m}$; width $2.6 \mathrm{~m}$; depth $0.23 \mathrm{~m}$ ). A pit containing burnt material on the southwest edge of the mound represents the trough associated with the mound's use (F880, Figure 6), and is again to do with cooking. Although roughly in the same spatial location as the Late Neolithic cooking pits, the landscape environment had changed, and this is Early Bronze Age cooking with heat and water at a wetland edge. Three other burnt mounds have been revealed in the Must Farm landscape, all in similar low-lying or wetland edge locations (Knight et al. 2014). Higher up, on the middle gravel terrace, northwest from the previous blocks of test-pits, Block 2 revealed a concentrated spread of midden material within the upper part of the buried soil (Figure 2). The material consisted of Beaker (fine and coarse forms), flint work (including broken barbed and tanged arrowheads), animal bone (sheep and boar/pig), and burnt stone in a charcoalrich spread. An accumulation of material generated by a slightly larger group(s), and all of the artefacts that were recovered were Early Bronze Age (unlike the other areas of test-pit sampling). Just south of the midden, we excavated a group of 12 small and medium-sized pits, with two shallow hearth pits at the edges of the cluster of features. Again this is evidence of a slightly larger group. The largest and deepest pit, F.964, was filled with a sequence of ash dumps, with the other pits containing charcoal-rich fills (see also Bamford 1982, Gibson 1982 and 2019, for similar Early Bronze Age settlement evidence). Indeed, this 'site' is characteristic of what Alex Gibson describes as 'structured or complex pits' (2019: 321). Large fragments of Beaker pottery (with refits) were recovered from the features, alongside several thumbnail scrapers, awls, and fragments of animal bone (boar/pig and sheep). This pit cluster created a setting for a larger group to carry out multiple tasks whilst also preparing, cooking and eating food. There is a focus on working hides (e.g. scrapers and awls), and the time between the use/breakage and deposition of the pottery is shorter. There is a shorter duration between the carrying out of task activities and the deposition of things in pits. To the east of this cluster, a medium-sized pit was excavated containing charcoal-rich fills and burnt stones. It also contained slag in its upper fill (Figure 7), evidence of metalworking having taken place nearby. The midden and pit cluster are close-by, and there is no larger-scale zone or broader distribution of contemporary material culture from the test-pit sampling.

Near to the northwest corner of the assessed area, an Early Bronze Age roundhouse (F854, F855 and F856, Figure 2) was excavated by the Cambridge Archaeological Unit (Knight et al. 2014). If we connect the Early Bronze Age evidence of the roundhouse, midden and pits, and burnt mound together, then we see a line of movement across the contours of the landscape from the upper to lower gravel terraces. Interestingly, the middle and lower terraces see the densest evidence for occupation in the Early Bronze 


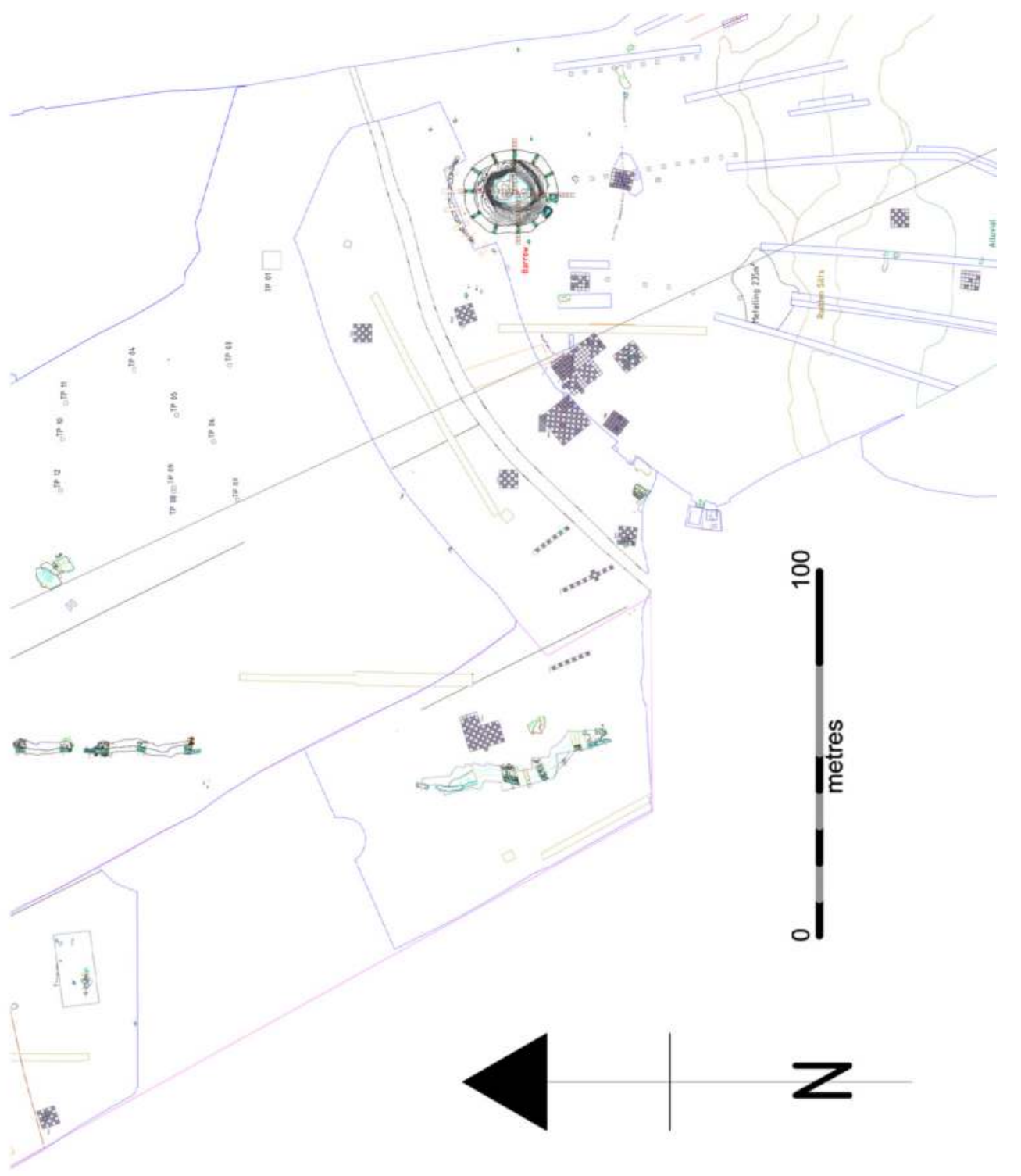

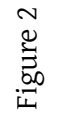

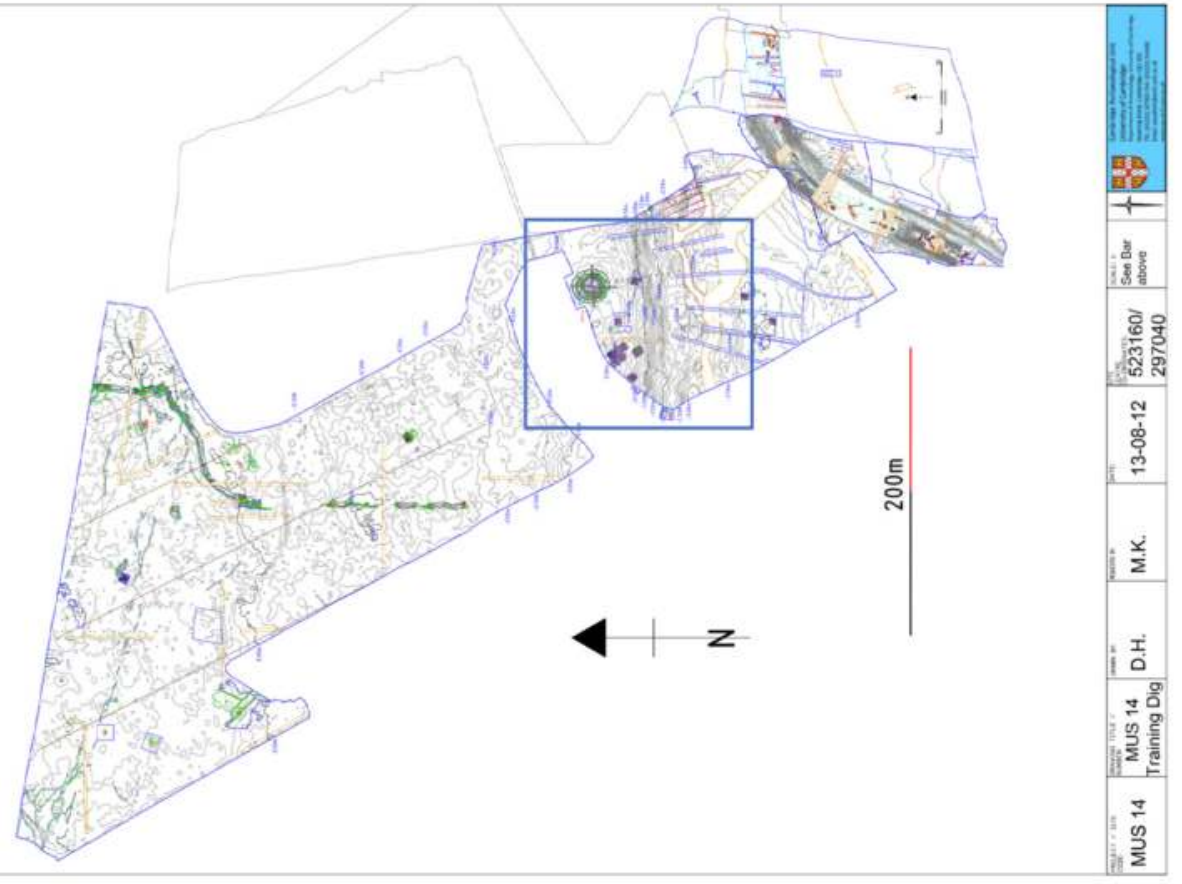




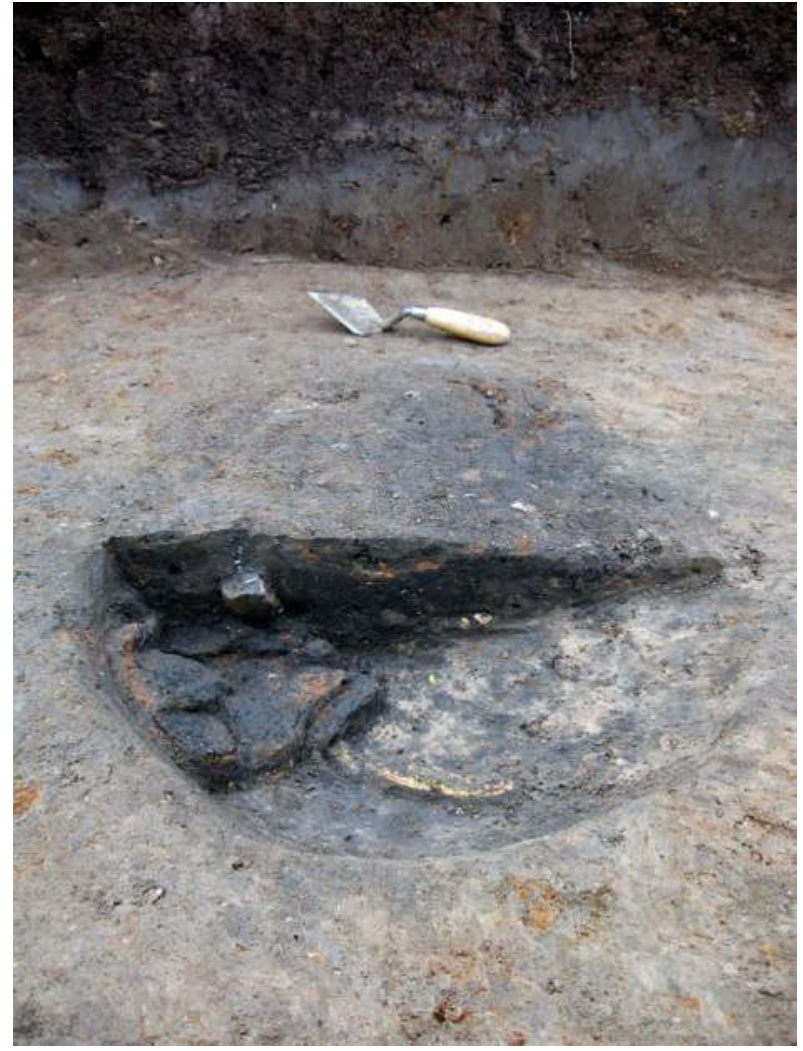

Figure 3

Age, with larger-scale social arenas of action, or arenas that develop in size through repeated visits. The middle terrace sees a density to occupation in the Late Neolithic and Early Bronze Age, and in both cases a broad range of activities are also associated with the cutting, use and deposition of pits. However, these are not contemporary practices, as was the case with Avebury and Stonehenge. What is key is that in the Early Bronze Age, the middle gravel terrace at Must Farm continued to be busy with occupation by larger groups in taskspecific (cooking) and multi-task activities (working flint, cutting, carpentry, butchering animals, working hides, preparing, cooking and eating food, and metalworking). There is evidence for hunting. Again, there is a sense of mobility with domestic animals, although with sheep and pigs. The dynamic to that mobility is more focussed or tethered to portions of the landscape centred on house, pits, and burnt stone mound, for short cycles of time. There is an attachment to this landscape, even though the wetland edge had started to encroach on the land that was available for settlement (Clark et al. 1935). The key question this brings to the fore, archaeologically, is how could this attachment have come about? People wanted to stay and keep in with this landscape, there is a tenure and endurance to occupation, and in order for that to continue into the future, there had to be further terms and timings to this occupation. For slightly later on, fencelines are constructed to demarcate portions of more permanent dryland and also periodic wetland, and in order to manage animals and humans in this changing terraceedge location. An on-going relationship with this landscape, and a determination to stay in it, required situated knowledge. An archaeological argument has to consider the conditions and implications for this kind of knowledge. Furthermore, what this landscape has, that Avebury and Stonehenge do not, is that there is a finite tenure to occupation, it has a duration up to pre$1500 \mathrm{BC}$ before all of the middle gravel terrace became wetland. This is a landscape that only holds Neolithic and Early Bronze Age archaeology within it.

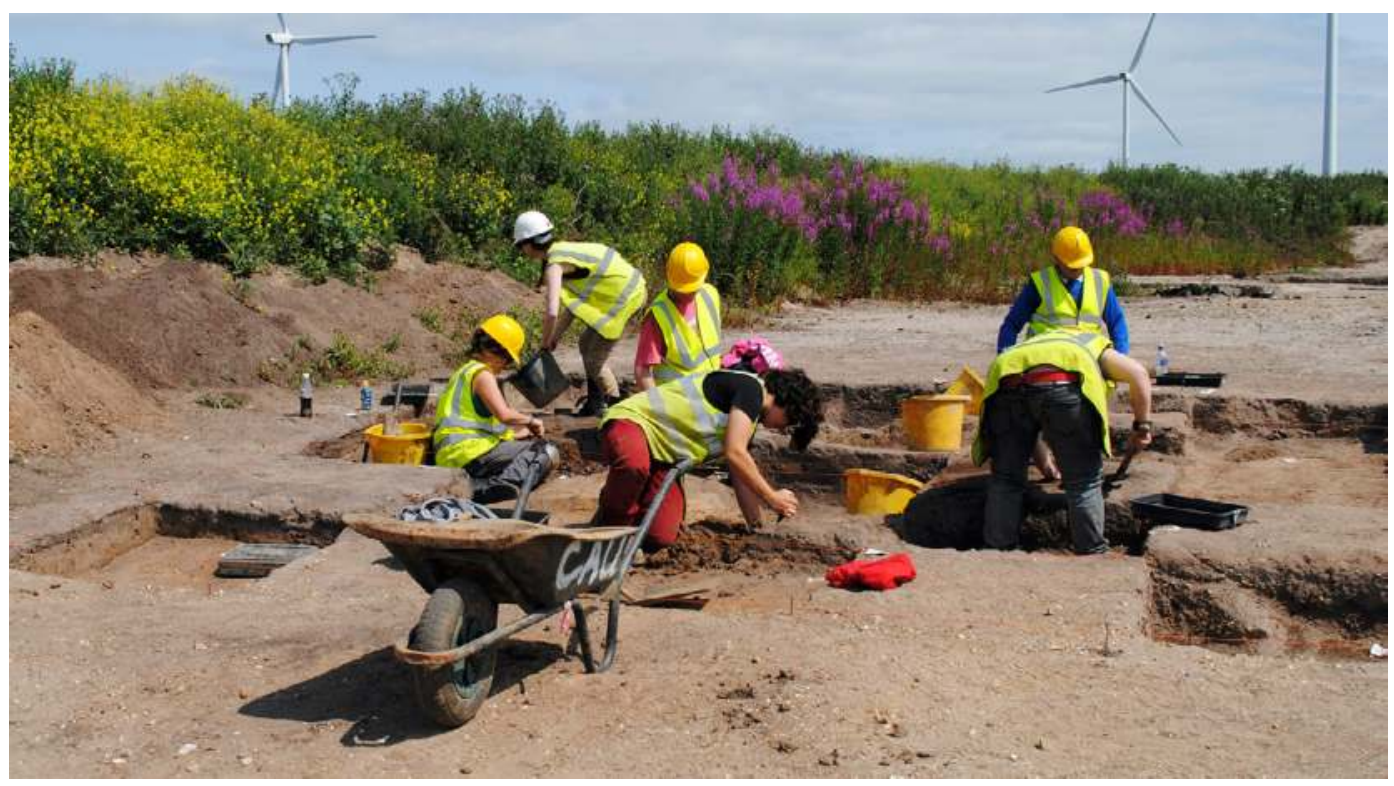

Figure 4 

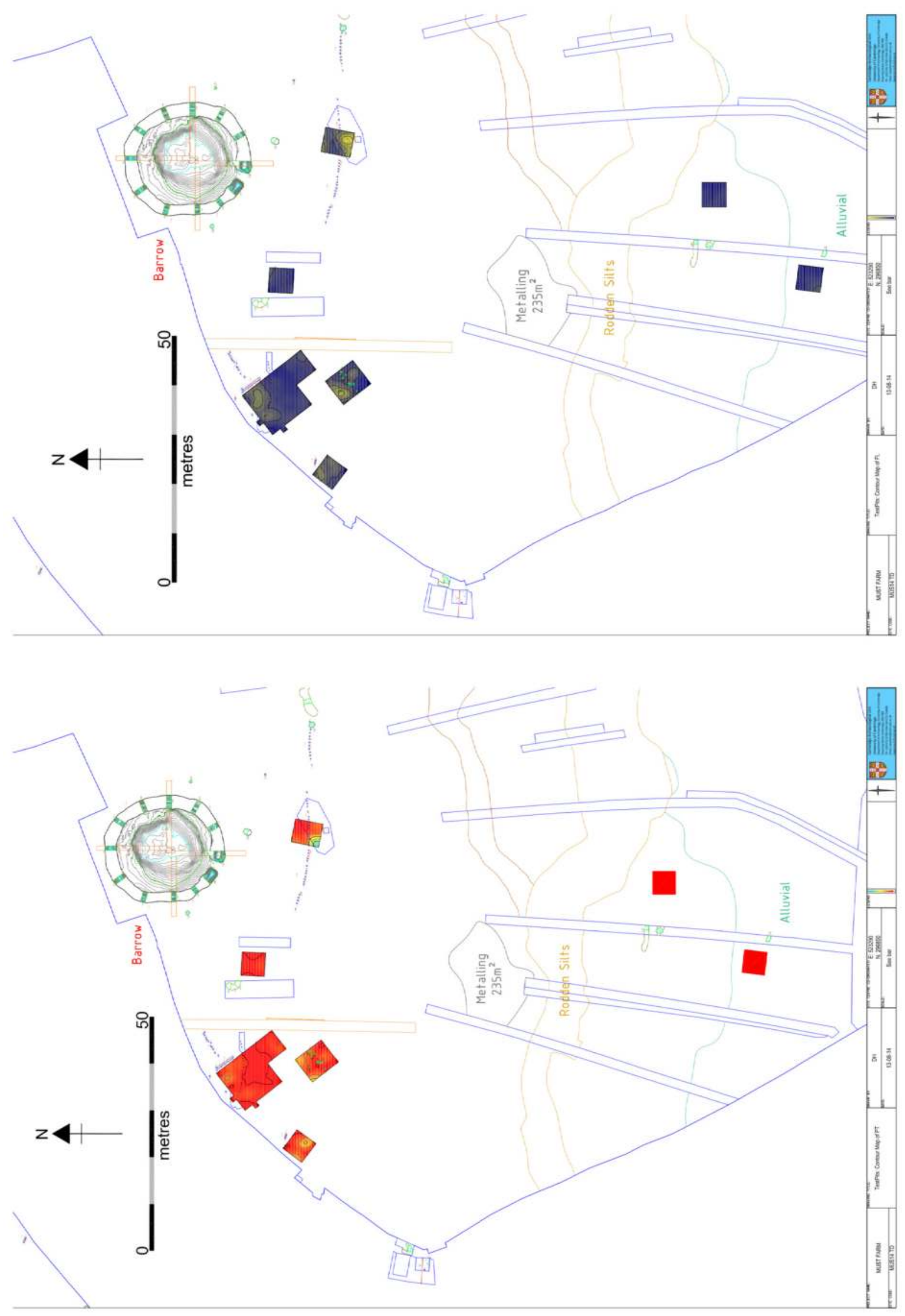


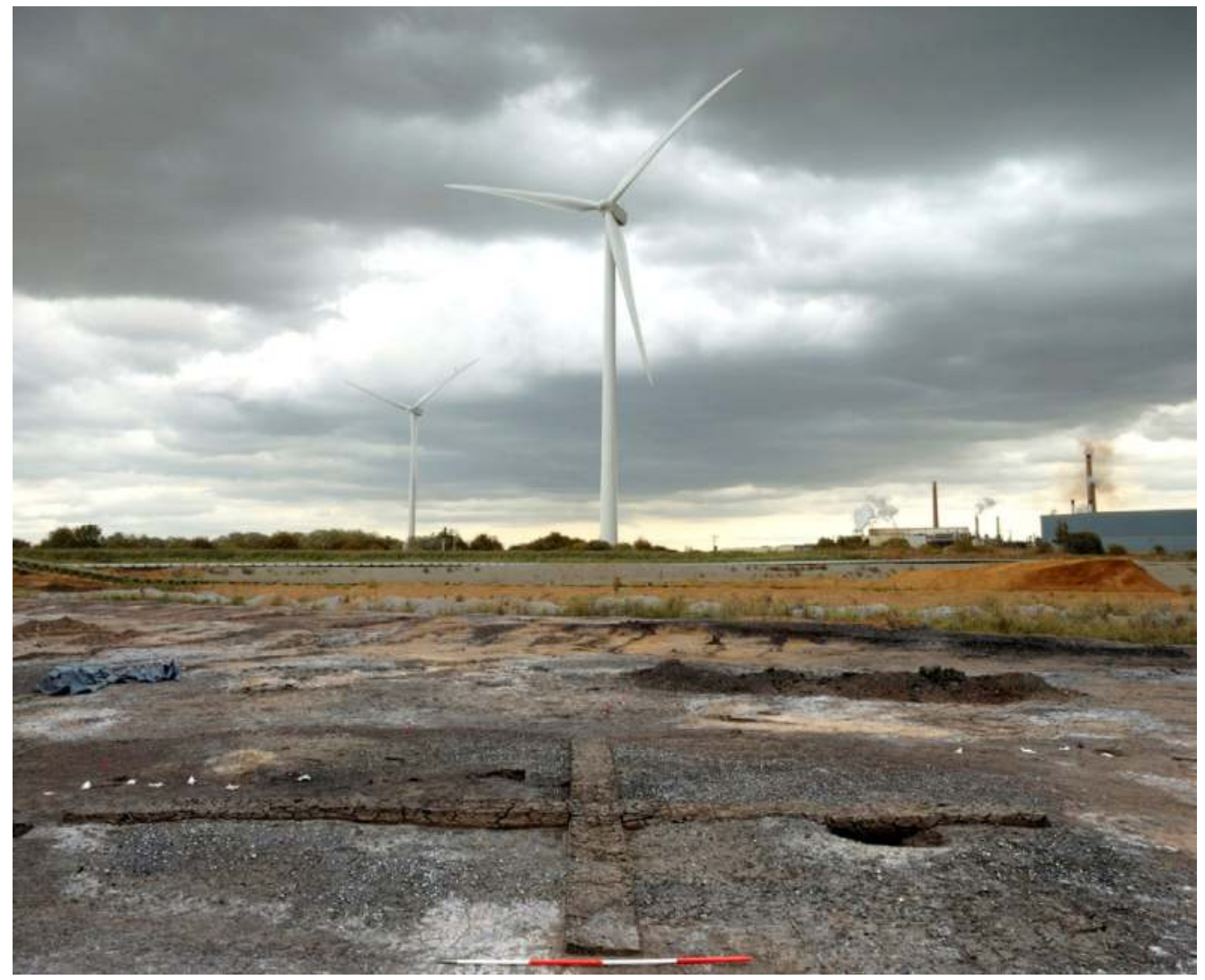

Figure 6

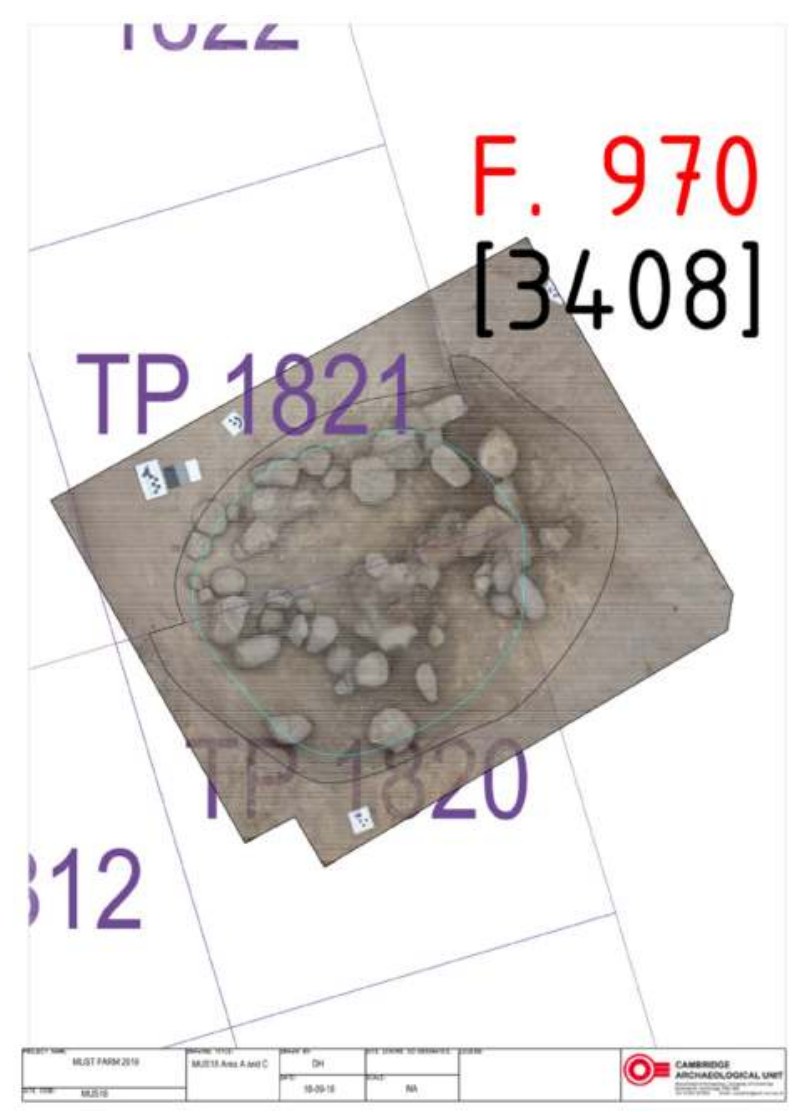

Figure 7
On a regional scale, Helen Bamford has already noted the presence of Early Bronze Age domestic sites in similar locations, and she writes '... Methwold, Shippea Hill, Mildenhall, and most of the sites around Lakenheath, are in the same Breck-Fen region and situated on sand hills in the peat' (1982: 33). Interestingly, the Beaker pottery found at these sites is not from the earliest of wares: 'Nearly all the Fen edge sites produced Southern Beaker material only, or, occasionally, a mixture of Southern, East Anglian and All-Over-Corded/European Beaker' (1982: 33) ${ }^{2}$. So my argument, and the nature of the evidence, unlike that for Cleal and Pollard (2012), is not one of contemporaneous practice in a shared landscape across the Late Neolithic into the Early Bronze Age. It is, instead, an argument and an evidence based on the tenure and endurance of occupation in the Early Bronze Age itself. So rather than constructing an argument across the Neolithic and into the Early Bronze Age, it is instead a matter of 'looking in from' the Early Bronze Age. We have to ask how this kind of landscape could have been known, and occupied in such an embedded and nuanced way, if there were not connections in the nature of practice, in similar occupation practices?

2 It should be noted that the early dates for All-Over-Corded/ European Beaker in Britain are for grave sites, for funerary evidence, and not for domestic sites, as is the case with the East Anglian examples mentioned here. 


\section{Situated knowledge}

The feminist theorist Donna Haraway (1991) would describe this resolution, and the nature of the practice and the possibilities for knowledge transfer, as 'situated knowledge'. Why this concept from feminist theory you might ask? It is because she explicitly argues that contingent worlds rely on situated knowledge. For Haraway, knowledge is configured through a particular and specific embodiment but in a political and social arena. It is important that knowledge is particular and political. This concern with politics is currently missing in current archaeological accounts based on a dwelling perspective (after Ingold 1993). With Haraway, there is a powerful bottom-up transformative capacity to occupation practices. Interestingly, Haraway's line of theory has been picked up on by the architect Jeremy Till in his consideration of an architecture/built environment that is dependent. $\mathrm{He}$ is also inspired by the way in which situated knowledge explores opportunities in the particular rather than the universal scheme of things, and he asks 'What are the capabilities of the place?' (2009: 60). In archaeological terms, this is about understanding how knowledge emerges within the material and historical conditions of context, time is not a perspective (i.e. a matter of looking forwards or backwards), time is in place, and so is a matter of 'looking in from'.

I argue that these are effective terms for understanding the on-going occupation practices in the landscape being investigated at Must Farm. Technological knowledge at this site worked with the particular, and it was the particular nature of this arena of social action that allowed for knowledge transfer and landscape interaction. I argue, as Haraway does, and Till, that the particular and partial facilitate a more critical knowledge of the web of connections that are possible, and that these conditions created knowledge transfer with all of its attendant possibilities for active and transformative intervention (Haraway 1991). Situated knowledge required a duration to occupation, a tenacity, and so a knowledge of landscape in time. Chronological division, event and change, would not allow this landscape to be known.

Periodisation cannot solely be the basis for our question making processes in archaeology. Otherwise we will never escape the narrative device of event and change. If we go back to the context given by English Heritage, and review it in this light, surely renewed and sustained contact materialise with Beaker pottery? And we need to remember that of these long-distance networks evidenced through stable isotope and ancient DNA analysis, they were of specific burials, and so other networks existed.
'We know that periodization is problematic: it creates narrative structures that bind rather than assist; it essentialises; it brings with it implicit notions of directionality and progress; and leads to images of stasis within period boundaries, contrasted with radical change at the points of origin and demise...' (Cleal and Pollard 2012: 329). We need to stop thinking in terms of continuity or change, and instead think about the conditions through which landscapes are known. At Must Farm people wanted to stay and keep in with landscape, and yet our archaeological accounts keep missing this mark.

\section{Acknowledgements}

Thank you to Susana Lopes and Sergio Gomes for the invitation to speak at Entre o 3 e o 2 milenio AC: Que tipo de viragem?, and for the ways in which they think and practice their archaeology. Thank you to Mark Knight for his comments and ideas on the text. Thank you to Donald Horne, Cambridge Archaeological Unit, for the plan and artefact density graphics at Must Farm.

\section{References}

Allen, M., Gardiner, J. and Sheridan, A. (eds) 2012. Is there a British Chalcolithic?: people, place and polity in the later 3rd millennium. Oxford: Oxbow Books.

Barrett, J.C. 2006. Archaeology as the Investigation of the Contexts of Humanity, in D. Papaconstantinou Deconstructing Context. A Critical Approach to Archaeological Practice: 194-211. Oxford: Oxbow Books.

Bamford, H. 1982. Beaker Domestic Sites in the Fen Edge and East Anglia. East Anglian Archaeology 16. Dereham: Norfolk Archaeological Unit in conjunction with the Scole Archaeological Committee.

Clark, J.G.D. and Godwin, H., Godwin, M.E. and Clifford, M.H.1935. Report on Recent Excavations at Peacock's Farm, Shippea, Cambridgeshire. Antiquaries Journal 15: 284-319.

Childe, V.G. 1930. The Bronze Age. Cambridge: Cambridge University Press.

Cleal, R. and MacSween, A. (eds.) 1999. Grooved Ware in Britain and Ireland. Oxford: Oxbow Books.

Cleal, R. and Pollard, J. 2012. The Revenge of the Native: monuments, material culture, burial and other practices in the third quarter of the 3rd millennium BC in Wessex, in M. Allen, J. Gardiner and A. Sheridan (eds) Is there a British Chalcolithic?: people, place and polity in the later 3rd millennium: 317-332. Oxford: Oxbow Books.

Crellin, R. 2020. Change and Archaeology. London and New York: Routledge.

French,C.(in press). Buried soil-landscape development of the southern Flag Fen Basin, in M. Knight and M. Brudenell Pattern and Process: Landscape Prehistories 
from Whittlesey Brick Pits - The King's Dyke and Bradley Fen Excavations 1998-2004. CAU Flag Fen Basin Depth \& Time Series, Vol. 1. Cambridge: Cambridge Archaeological Unit.

Gibson, A.1982. Beaker Domestic Sites. Astudy of the domestic pottery of the late third and early second millennia B.C. in the British Isles. Part 1. British Archaeological Reports British Series 107(1). Oxford: British Archaeological Reports.

Gibson, A. 1998. Stonehenge and Timber Circles. Stroud: Tempus.

Gibson, A. 2019. Beaker domestic architecture in Britain and Ireland, in A. Gibson (ed.) Bell Beaker Settlement of Europe. The Bell Beaker phenomenon from a domestic perspective: 309-328. Prehistoric Research Paper 9. Oxford: Oxbow Books.

Haraway, D. 1991. Simians, Cyborgs and Women: the Reinvention of Nature. London: Free Association Books.

Ingold, T. 1993. The Temporality of the Landscape. World Archaeology 25(2): 152-174.

Knight, M., Robinson, I. and Middleton, L. 2014. Must Farm, Whittlesey. Phase 4 Archaeological Investigations. Cambridge Archaeological Unit, Report 1283. Cambridge: University of Cambridge.

Larsson, M. and Parker Pearson, M. (eds) 2007. From Stonehenge to the Baltic: living with cultural diversity in the third millennium BC. British Archaeological Reports International Series 1692. Oxford: Archaeopress.

Olalde, I. et al. 2018. The Beaker Phenomenon and the Genomic Transformation of Northwest Europe. Nature 555: 190-196.
Parker Pearson, M. 2012. Foreword, in M. Allen, J. Gardiner and A. Sheridan (eds) Is there a British Chalcolithic?: people, place and polity in the later 3rd millennium: xxvii-xxviii. Oxford: Oxbow Books.

Parker Pearson, M., Jay, M., Chamberlain, A., Sheridan, A. and Evans, J. 2019a. The Beaker People: Isotopes, Mobility and Diet in Prehistoric Britain. Oxford: Oxbow Books.

Parker Pearson, M., Pollard, J., Richards, C., Thomas, J. and Welham, K. 2019b. Stonehenge for the Ancestors: Part 1: Landscape and Monuments. Oxford: Oxbow Books.

Ray, K. and Thomas, J. 2018. Neolithic Britain. The transformation of social worlds. Oxford: Oxford University Press.

Till, J. 2009. Architecture Depends. Cambridge MA: MIT Press.

Wilkin, N. and Vander Linden, M. 2015. What was and what would never be: changing patterns of interaction and archaeological visibility across north-west Europe from 2500 to 1500 cal BC, in H. Anderson-Whymark, D. Garrow and F. Sturt (eds) Continental Connections. Exploring Cross-Channel Relationships from the Mesolithic to the Iron Age: 99-121. Oxford: Oxbow Books.

http://www.mustfarm.com

http://www.bbk.ac.uk/history/prospective-students/ explore-subjects/birkbeck-field-school 
Between the 3rd and 2nd Millennia BC: Exploring Cultural Diversity and Change in Late Prehistoric Communities is a collection of studies on the cultural reconfigurations that occurred in western Europe between the $3 \mathrm{rd}$ and $2 \mathrm{nd}$ millennia BC. It brings together seven texts focusing on the evidence from the West of the Iberian Peninsula, and one on the South of England. The texts have their origin in a landmark meeting held at the University of Coimbra in November 2018, where scholars explored the grand narratives explaining the differences between what are traditionally considered Chalcolithic (or Late Neolithic) and Bronze Age communities. The contributions look at key aspects of these grand narratives through regional perspectives, asking the following questions: is there clear data to support the idea of an intensification of social complexity towards the emergence of the Bronze Age chiefdoms? What is the role of monumental architecture within this process? How do we best discuss the different levels of architectural visibility during this period? How can we interpret collective and individual burials in relation to the emergence of individual/territorial powers? In answering these questions, the papers explore regional diversity and argue that regional specificities resist a general interpretation of the historical process at stake. In light of this resistance, the book emphasizes that cultural singularities only become visible through contextual, medium, or low-scale approaches. The recognition of singularities challenges grand narratives, but also carries the potential to expand our understanding of the changes that occurred during this key moment of Late Prehistory. The book thus offers readers the opportunity to think about the diversity of archaeological evidence in combination with an exploration of the available range of approaches and narratives. The critical intertwining of multiple points of view is necessary, because it gets us closer to how elusive the cultural differences of prehistoric communities can be. This elusive dimension is precisely what can force us to constantly rethink what we see and what questions we ask.

Susana Soares Lopes is a researcher at CEAACP - University of Coimbra (Portugal). She is a retired full professor in archaeology at the University of Porto (Portugal), where she taught from 1975 to 2013. Her research, focusing on the Late Prehistory of the Iberian Peninsula, has explored archaeological sites in northern Portugal by integrating a variety of theoretical orientations. She uses this plurality to promote and discuss different perspectives on Prehistory.

Sérgio Alexandre Gomes is a researcher at CEAACP - University of Coimbra (Portugal). His main interests lie in the history of archaeology, archaeological methods and theories, as well as the study of the Late Prehistory of the Iberian Peninsula, with a focus on the archaeology of wall enclosures and pit sites. 